Campbell Systematic Reviews

2012:15

First published: $\quad$ April, 2000

Last updated: April, 2012

Search executed: $\quad$ December, 2011

\title{
Group-based parent training programmes for improving parental psychosocial health
}

J ane Barlow, Nadja Smailagic, Nick Huband, Verena Roloff, Cathy Bennett 


\section{Colophon}

Title Group-based parent training programmes for improving parental psychosocial health

Institution The Campbell Collaboration

Authors Barlow, Jane

Smailagic, Nadja

Huband, Nick

Roloff, Verena

Bennett, Cathy

DOI $10.4073 /$ csr.2012.15

No. of pages 197

Last updated April, 2012

Citation Barlow, J., Smailagic, N., Huband, N., Roloff, V., Bennett, C. Group-based parent training programmes for improving parental psychosocial health. Campbell Systematic Reviews 2012:15

DOI: $10.4073 /$ csr.2012.15

ISSN $1891-1803$

Co-registration This review is co-registered within both the Cochrane and Campbell Collaborations. A version of this review can also be found in the Cochrane Library.

Contributions JB updated and wrote the background and discussion sections, edited the methods, wrote up results, gave advice about the set up of the analyses, overall responsibility for ensuring data in the review are correct. NS reviewed the draft and scope of the review with the contact author of the review (J B). Searched for potential included studies from searches run by the CDPLP Group, identified included studies, checked the old excluded studies and excluded newly found studies that did not fit the inclusion criteria. Managed data extraction and entry. Completed the tables of characteristics of studies, extracted data, competed 'Risk of bias' tables (RoB), extracted data for use in analysis, constructed outcomes tables, checked the existing included studies data, entered data into the analysis table, set up metaanalyses, wrote up methods and results section, inserted analysis results into text, entered and checked references, attended progress meetings, responsible for working collaboratively with other authors to meet publication deadlines.

CB worked with all review authors to ensure that the review met publication deadlines. Contributed to the methods section, analyses, recorded outcomes for drafts of the additional tables, excluded studies table. General review and publication support.

$\mathrm{NH}$ identified potential included studies, jointly finalised list of included studies with NS, data extraction, entry of RoB data for new included studies checking data entry, tables of characteristics of studies, extracted data, contributed to 'Risk of bias' tables (RoB), extracted data for use in analysis, entered data into analysis table, set up meta-analyses, wrote up results section, inserted analysis results into text.

VR contributed the investigation of cluster effects, contributed to the analysis plan and advised about the set up of analyses. 
Editors for Editors: William Turner, Geraldine Macdonald

this review Managing editors: Laura MacDonald, J ane Dennis

Support/funding UK Cochrane Centre, UK

Health Services Research Unit at the University of Warwick, UK

Institute of Mental Health, Nottinghamshire Healthcare NHS Trust, UK

NHS Cochrane Collaboration Programme Grant Scheme (NIHR), UK

Potential conflicts J ane Barlow - none known.

of interest Nadja Smailagic - none known.

Nick Huband - none known.

Verena Roloff - none known.

Cathy Bennett - I am employed by Systematic Research Ltd and I received a

consultancy fee for my contributions to this review.

$\begin{aligned} \begin{array}{r}\text { Corresponding } \\ \text { author }\end{array} & \text { Jane Barlow } \\ & \text { Health Sciences Research Unit } \\ & \text { Warwick Medical School } \\ & \text { University of Warwick } \\ & \text { Gibbett Hill Road } \\ & \text { Coventry } \\ & \text { CV4 7AL } \\ & \text { UK } \\ & \text { E-mail: jane.barlow@warwick.ac.uk }\end{aligned}$




\section{Campbell Systematic Reviews}

Editors-in-Chief Mark W. Lipsey, Vanderbilt University, USA

Arild Bjørndal, The Centre for Child and Adolescent Mental Health, Eastern and Southern Norway \& University of Oslo, Norway

Editors

Crime and J ustice David B. Wilson, George Mason University, USA

Education Sandra Wilson, Vanderbilt University, USA

Social Welfare William Turner, University of Bristol, UK

Geraldine Macdonald, Queen's University, UK \& Cochrane Developmental,

Psychosocial and Learning Problems Group

International Birte Snilstveit, 3ie, UK

Development Hugh Waddington, 3ie, UK

Managing Editor Karianne Thune Hammerstrøm, The Campbell Collaboration

Editorial Board

Crime and J ustice David B. Wilson, George Mason University, USA

Martin Killias, University of Zurich, Switzerland

Education Paul Connolly, Queen's University, UK

Gary W. Ritter, University of Arkansas, USA

Social Welfare Aron Shlonsky, University of Toronto, Canada

J ane Barlow, University of Warwick, UK

International Peter Tugwell, University of Ottawa, Canada

Development Howard White, 3ie, India

Methods Therese Pigott, Loyola University, USA

Ian Shemilt, University of Cambridge, UK

The Campbell Collaboration (C2) was founded on the principle that systematic reviews on the effects of interventions will inform and help improve policy and services. C2 offers editorial and methodological support to review authors throughout the process of producing a systematic review. A number of C2's editors, librarians, methodologists and external peerreviewers contribute.

The Campbell Collaboration P.O. Box 7004 St. Olavs plass 0130 Oslo, Norway www.campbellcollaboration.org 


\section{Table of contents}

$\begin{array}{lc}\text { TABLE OF CONTENTS } & 4\end{array}$

$\begin{array}{lr}\text { ABSTRACT } & 6\end{array}$

Background $\quad 6$

$\begin{array}{ll}\text { Objectives } & 6\end{array}$

Search methods $\quad 6$

$\begin{array}{ll}\text { Selection criteria } & 6\end{array}$

$\begin{array}{ll}\text { Data collection and analysis } & 7\end{array}$

$\begin{array}{ll}\text { Results } & 7\end{array}$

$\begin{array}{lr}\text { Authors' conclusions } & 7\end{array}$

$\begin{array}{lr}\text { PLAIN LANGUAGE SUMMARY } & 8\end{array}$

Parent training for improving parental psychosocial health 8

1 BACKGROUND $\quad 10$

1.1 Description of the condition 10

1.2 Description of the intervention 12

1.3 How the intervention might work 13

1.4 Why it is important to do this review 14

2 OBJ ECTIVES $\quad 15$

3 METHODS $\quad 16$

3.1 Criteria for considering studies for this review 16

3.2 Search methods for identification of studies 19

3.3 Data collection and analysis 20

4 RESULTS $\quad \mathbf{2 4}$

4.1 Description of studies 24

4.2 Risk of bias in included studies 31

4.3 Effects of interventions 33

5 DISCUSSION $\quad 38$

5.1 Summary of main results 38

5.2 Overall completeness and applicability of evidence 39

$\begin{array}{lll}5.3 & \text { Quality of the evidence } & 39\end{array}$

5.4 Potential biases in the review process 39

5.5 Agreements and disagreements with other studies or reviews 39 
$6 \quad$ AUTHORS' CONCLUSIONS $\quad 41$

6.1 Implications for practice 41

$\begin{array}{lll}6.2 & \text { Implications for research } & 41\end{array}$

$7 \quad$ ACKNOWLEDGEMENTS

8 DIFFERENCES BETWEEN PROTOCOL AND REVIEW 43

9 CHARACTERISTICS OF STUDIES

9.1 Characteristics of included studies 45

$\begin{array}{lll}9.2 & \text { Characteristics of excluded studies } & 135\end{array}$

$\begin{array}{lll}9.3 & \text { Characteristics of studies awaiting classification } & 145\end{array}$

$\begin{array}{lll}9.4 & \text { Characteristics of ongoing studies } & 147\end{array}$

10 REFERENCES TO STUDIES $\quad 148$

$\begin{array}{lll}10.1 & \text { Included studies } & 148\end{array}$

$\begin{array}{lll}10.2 & \text { Excluded studies } & 155\end{array}$

$\begin{array}{lll}10.3 & \text { Studies awaiting classification } & 170\end{array}$

$\begin{array}{lll}10.4 & \text { Ongoing studies } & 171\end{array}$

11 OTHER REFERENCES 172

$\begin{array}{lll}11.1 & \text { Additional references } & 172\end{array}$

11.2 Other published versions of this review 177

12 DATA AND ANALYSES 178

12.1 Meta analysis: any parent training programme versus control (parental $\begin{array}{ll}\text { outcomes) } & 178\end{array}$ 12.2 Appendix to data and analyses section, results from individual studies (no meta-analysis): any parent training programme versus control 181

13 FIGURES 192

13.1 Risk of bias summary: review authors' judgements about each risk of each included study 192

14 APPENDICES 195

$\begin{array}{lll}14.1 & \text { Search strategy } & 195\end{array}$ 


\section{Abstract}

\section{BACKGROUND}

Parental psychosocial health can have a significant effect on the parent-child relationship, with consequences for the later psychological health of the child. Parenting programmes have been shown to have an impact on the emotional and behavioural adjustment of children, but there have been no reviews to date of their impact on parental psychosocial wellbeing.

\section{OBJ ECTIVES}

To address whether group-based parenting programmes are effective in improving parental psychosocial wellbeing (for example, anxiety, depression, guilt, confidence).

\section{SEARCH METHODS}

We searched the following databases on 5 December 2012: CENTRAL (2011, Issue 4), MEDLINE (1950 to November 2011), EMBASE (1980 to week 48, 2011), BIOSIS (1970 to 2 December 2011), CINAHL (1982 to November 2011), PsycINFO (1970 to November week 5, 2011), ERIC (1966 to November 2011), Sociological Abstracts (1952 to November 2011), Social Science Citation Index (1970 to 2 December 2011), metaRegister of Controlled Trials (5 December 2011), NSPCC Library (5 December 2011). We searched ASSIA (1980 to current) on 10 November 2012 and the National Research Register was last searched in 2005.

\section{SELECTION CRITERIA}

We included randomised controlled trials that compared a group-based parenting programme with a control condition and used at least one standardised measure of parental psychosocial health. Control conditions could be waiting-list, no treatment, treatment as usual or a placebo. 


\section{DATA COLLECTION AND ANALYSIS}

At least two review authors extracted data independently and assessed the risk of bias in each study. We examined the studies for any information on adverse effects. We contacted authors where information was missing from trial reports. We standardised the treatment effect for each outcome in each study by dividing the mean difference in post-intervention scores between the intervention and control groups by the pooled standard deviation.

\section{RESULTS}

We included 48 studies that involved 4937 participants and covered three types of programme: behavioural, cognitive-behavioural and multimodal. Overall, we found that group-based parenting programmes led to statistically significant short-term improvements in depression (standardised mean difference (SMD) - 0.17, 95\% confidence interval (CI) -0.28 to -0.07), anxiety (SMD -0.22, 95\% CI - 0.43 to -0.01), stress (SMD - $0.29,95 \%$ CI - 0.42 to -0.15), anger (SMD -0.60, 95\% CI - 1.00 to 0.20 ), guilt (SMD - $0.79,95 \%$ CI -1.18 to -0.41 ), confidence (SMD - $0.34,95 \%$ CI -0.51 to -0.17 ) and satisfaction with the partner relationship (SMD - $0.28,95 \% \mathrm{CI}-0.47$ to -0.09). However, only stress and confidence continued to be statistically significant at six month follow-up, and none were significant at one year. There was no evidence of any effect on self-esteem (SMD - 0.01, 95\% CI -0.45 to 0.42). None of the trials reported on aggression or adverse effects.

The limited data that explicitly focused on outcomes for fathers showed a statistically significant short-term improvement in paternal stress (SMD -0.43, 95\% CI - 0.79 to -0.06). We were unable to combine data for other outcomes and individual study results were inconclusive in terms of any effect on depressive symptoms, confidence or partner satisfaction.

\section{AUTHORS' CONCLUSIONS}

The findings of this review support the use of parenting programmes to improve the short-term psychosocial wellbeing of parents. Further input may be required to ensure that these results are maintained. More research is needed that explicitly addresses the benefits for fathers, and that examines the comparative effectiveness of different types of programme along with the mechanisms by which such programmes bring about improvements in parental psychosocial functioning. 


\section{Plain language summary}

\section{PARENT TRAINING FOR IMPROVING PARENTAL PSYCHOSOCIAL HEALTH}

Parental psychosocial health can have a significant effect on the parent-child relationship, with consequences for the later psychological health of the child. Some parenting programmes aim to improve aspects of parental wellbeing and this review specifically looked at whether group-based parenting programmes are effective in improving any aspects of parental psychosocial health (for example, anxiety, depression, guilt, confidence).

We searched electronic databases for randomised controlled trials in which participants had been allocated to an experimental or a control group, and which reported results from at least one scientifically standardised measure of parental psychosocial health.

We included a total of 48 studies that involved 4937 participants and covered three types of programme: behavioural, cognitive-behavioural and multimodal. Overall, the results suggested statistically significant improvements in the short-term for parental depression, anxiety, stress, anger, guilt, confidence and satisfaction with the partner relationship. However, only stress and confidence continued to be statistically significant at six month follow-up, and none were significant at one year. There was no evidence of effectiveness for self-esteem at any time point. None of the studies reported aggression or adverse outcomes.

Only four studies reported the outcomes for fathers separately. These limited data showed a statistically significant short-term improvement in paternal stress but did not show whether the parenting programmes were helpful in terms of improving depressive symptoms, confidence or partner satisfaction.

This review shows evidence of the short-term benefits of parenting programmes on depression, anxiety, stress, anger, guilt, confidence and satisfaction with the partner relationship. The findings suggest that further input may be needed to support parents to maintain these benefits. However, more research is needed that explicitly addresses the benefits for fathers, and that provides evidence of the comparative 
effectiveness of different types of programme and identifies the mechanisms involved in bringing about change. 


\section{Background}

\subsection{DESCRIPTION OF THE CONDITION}

Parental psychosocial functioning is a significant factor influencing a range of aspects of children's development and wellbeing (see below). It consists of a wide range of components but those most frequently researched in terms of their impact on the wellbeing of children include parental mental health (that is depression and anxiety, parental confidence and parental conflict). The available evidence relates to infancy and toddlerhood, and to mid-childhood and adolescence.

\subsubsection{Infant and toddlerhood}

The postnatal period has been identified as being of particular importance in terms of the infant's need for affectively attuned parenting ( $\mathrm{J}$ affe 2001) and for parental reflective functioning (Fonagy 1997), both of which are now thought to be central to the infant's capacity to develop a secure attachment to the primary caregiver (Van IJ zendoorn 1995; Grienenberger 2005). Parental psychosocial functioning can impact on the parent's capacity to provide this type of parenting. For example, one study found that depressed mothers were less sensitively attuned to their infants, less affirming and more negating of infant experience compared with parents not experiencing postnatal depression (Murray 1992); and that these infants had poorer cognitive outcomes at 18 months (Murray 1996), performed less well on object concept tasks, were more insecurely attached to their mothers and showed more behavioural difficulties (Murray 1996). Boys of postnatally depressed mothers may also score lower on standardised tests of intellectual attainment (Sharp 1995). A clinical diagnosis of postnatal depression is associated with a fourfold increase in risk of psychiatric diagnosis at age 11 years (Pawlby 2008). Recent research has also identified that the impact of postnatal depression on insecure child attachment may be moderated by maternal attachment state of mind (McMahon 2006). The chronicity of the depression appears to be a significant predictor, with depression lasting throughout the first 12 months being associated with poorer cognitive and psychomotor development for both boys and girls compared with no evidence of impact for brief periods of depression (Cornish 2008).

Recent research shows that paternal postnatal depression can have an effect that is similar in magnitude to that of maternal depression. Ramchandani 2008 showed that boys of fathers who were depressed during the postnatal period had an 
increased risk of conduct problems at age 3.5 years, and that boys of fathers who were depressed during both the prenatal and postnatal periods had the highest risks of subsequent psychopathology at 3.5 years and psychiatric diagnosis at seven years of age (Ramchandani 2008).

Neurodevelopmental research suggests that postnatal depression impacts the child's developing neurological system (Schore 2005). For example, one study found that infants of depressed mothers exhibited reduced left frontal electroencephalogram (EEG) activity (Dawson 1997). Parent-infant interaction can also impact on the infant's stress regulatory system, one study showing that exposure to stress during the early postnatal period that was not mediated by sensitive parental caregiving had an impact on the infant's hypothalamic-pituitary-adrenocorticol (HPA) system (Gunnar 1994), which plays a major role in both the production and regulation of glucocorticoid cortisol in response to such stress.

Maternal anxiety during the postnatal period is also associated with poorer outcomes. For example, Beebe 2011 found that maternal anxiety biased the interaction toward interactive contingencies that were both heightened (vigilant) in some modalities and lowered (withdrawn) in others, as opposed to being in the 'mid-range', which has been identified as optimal for later development, including secure attachment (Beebe 2011).

\subsubsection{Mid-childhood and adolescence}

There is also evidence to show a significant impact of parental psychosocial functioning on older children. A review of longitudinal studies found that by the age of 20 years, children of affectively ill parents have a $40 \%$ chance of experiencing an episode of major depression and are more likely to exhibit general difficulties in functioning, including increased guilt and interpersonal difficulties such as problems with attachment (Beardslee 1998). More recently, maternal psychological distress has been identified as being a risk factor for conduct and emotional problems. Parry-Langdon 2008 found that higher scores on the General Health Questionnaire (GHQ-12) were an independent risk factor for conduct disorder (odds ratio (OR) 2.2) and for child emotional problems (OR 2.2). This OR increased to 3.5 for both emotional and behavioural problems where maternal scores on the GHQ-12 were initially low and then subsequently increased.

One longitudinal study that focused on parental conflict found that adolescents' perceptions of typical interparental conflict directly predicted increases in depressive symptoms (particularly for girls) and aggressive behaviours (particularly for boys) over a period of a year, and that this was not mediated by parental style or quality (McGuinn 2004). This study found a significant impact on the wellbeing of adolescents who witnessed even 'normative' marital discord. Another aspect of parental psychosocial functioning is parental confidence, which has been shown to be strongly associated with parent-child interactions that are characterised by inconsistency, guilt, detachment and anxiety (Martin 2000). One meta-analysis also 
found that paternal depression was significantly related to internalising and externalising psychopathology in children, and to father-child conflict (Kane 2004).

It is suggested that the mechanism linking parental psychosocial functioning and child outcomes is the impact of such functioning on parenting behaviours, and Waylen 2010 found that worsening parental mental health was associated with reduced parenting capacity. Similarly, Wilson 2010 found a significant deleterious impact of paternal depression on both positive and negative parenting behaviours. One longitudinal study also suggested a more complex pathway in which parental depressive symptoms were associated 12 months later with increased insecurity in adult close relationships and interparental conflict (Shelton 2008). This study showed that such conflict had a negative impact on children's appraisals of parents, which was in turn was associated with children's internalising and externalising problems (Shelton 2008).

Overall, this evidence suggests that parental psychosocial functioning can impact on the parents' capacity to provide affectively attuned interaction during infancy and toddlerhood, and an impact on older children as a result of the consequences of compromised parental psychosocial functioning for parenting behaviours and marital adjustment. There is, therefore, considerable potential for interventions aimed at promoting the psychosocial wellbeing of parents to reduce the disruption to the child's emotional, educational and social adjustment, and thereby to promote the mental health of future generations.

\subsection{DESCRIPTION OF THE INTERVENTION}

Parenting programmes are underpinned by a range of theoretical approaches (including behavioural, cognitive-behavioural, family systems, Adlerian) and can involve the use of a range of techniques in their delivery including discussion, role play, watching video vignettes and homework. Behavioural parenting programmes are based on social learning principles and teach parents how to use a range of basic behavioural strategies for managing children's behaviour, and some of these programmes involve the use of videotape modelling. Cognitive parenting programmes are aimed at helping parents to identify and change distorted patterns of belief or thought that may be influencing their behaviour, and cognitivebehavioural programmes combine elements of both types of strategy. Other types of programme often combine some of these strategies. For example, Adlerian programmes focus on the use of 'natural and logical consequences' and 'reflective listening' strategies.

Parenting programmes are typically offered to parents over the course of eight to 12 weeks, for about one to two hours each week. They can be delivered on a one-to-one basis or to groups of parents and are provided in a number of settings, ranging from hospital or social work clinics to community-based settings such as general practitioner (GP) surgeries, schools and churches. They typically involve the use of a 
manualised and standardised programme or curriculum, and are aimed at increasing the knowledge, skills and understanding of parents.

Recent evidence shows that parenting programmes can improve the emotional and behavioural adjustment of children under three years (Barlow 2010) and of children aged three to 10 years with conduct and behaviour problems (Dretze 2005). A review of studies focused on teenage parents found that parenting programmes improved parental responsiveness to the child and parent-child interaction (Barlow 2011). Reviews of qualitative evidence point to a range of benefits of taking part in a group with other parents (Kane 2003).

\subsection{HOW THE INTERVENTION MIGHT WORK}

The mechanism by which parenting programmes may impact on parental psychosocial wellbeing is thought to be twofold. Firstly, parenting programmes are, on the whole, strengths-based, and are aimed at enhancing parental capacity and changing parenting attitudes and practices in a non-judgemental and supportive manner, with the overall aim of improving child emotional and behavioural adjustment. For example, Patterson's coercion theory (Patterson 1992) demonstrates the way in which parents are increasingly disempowered as a result of a process of escalation in which parents who 'give in' to child demands are increasingly likely to need more coercive strategies on the next occasion. The process in which problems escalate and parents feel increasingly disempowered may explain in part why parents experience stress and depression directly related to the parenting role. The potential impact of parenting programmes on parental psychosocial functioning may be due to the way in which such programmes help parents to address significant issues in terms of their child's wellbeing, and increase their skills and capacity to support their child's physical and emotional development (for example, Dretze 2005; Barlow 2011).

Secondly, many parenting programmes, particularly those that are underpinned by a cognitive or cognitive-behavioural approach, may also provide parents with strategies that are directly aimed at improving parental psychological functioning. Any improvements that occur may be a result of the parents' application of such strategies to themselves instead of, or in addition to, the use of strategies focused on improving child behaviour.

Research also suggests that parenting programmes can improve other aspects of parental psychosocial functioning such as marital relations and parenting stress (Todres 1993). Factors such as marital conflict and parental stress can have a direct impact on children, in addition to being mediators of other parental problems (for example, poor mental health). Improvements in marital conflict and parental stress will, as such, have beneficial consequences in terms of children's later development. 
Thus, although a number of studies have shown that parenting programmes can have an impact on aspects of maternal mental health and wellbeing, including reducing anxiety (Morawska 2009) and depression (Pisterman 1992a), it is not currently clear whether such improvements reflect the impact of strategies directly targeting parental mental health or whether they occur as an indirect result of the parent's improved ability to manage their children's behaviour and of improvements in family functioning more generally.

Therefore, although the causal mechanism is not entirely clear, parenting programmes appear to have considerable potential to impact one or more aspects of parental psychosocial functioning. It should be noted, however, that although parents who are experiencing anxiety and depression unrelated to the parenting role may also have a compromised ability to function as a parent, with consequences in terms of their children's wellbeing. The needs of such parents are not addressed by the current review, which does not include programmes provided to parents with clinical mental health or psychiatric problems.

\subsection{WHY IT IS IMPORTANT TO DO THIS REVIEW}

The aim of this review is to evaluate the effectiveness of group-based parenting programmes in improving the psychosocial health of parents, by appraising and collating evidence from existing studies that have used rigorous methodological designs and a range of standardised outcome instruments. The results will inform the broader debate concerning the role and effectiveness of parenting programmes. 


\section{Objectives}

To update an existing review examining the effectiveness of group-based parenting programmes in improving parental psychosocial health (for example, anxiety, depressive symptoms, self-esteem). 


\section{Methods}

\subsection{CRITERIA FOR CONSIDERING STUDIES FOR THIS REVIEW}

\subsubsection{Types of studies}

We included randomised controlled trials (RCTs) and quasi-randomised controlled trials in which participants had been randomly allocated to an experimental or a control group, the latter being a waiting-list, no treatment, treatment as usual (normal service provision) or a placebo control group.

Quasi-randomised controlled trials are defined as trials where allocation was done on the basis of a pseudo-random sequence, for example, odd or even hospital number, date of birth or alternation (Higgins 2008).

We did not include studies comparing two different therapeutic modalities (that is, without a control group).

\subsubsection{Types of participants}

We included studies that targeted adult (rather than teenage) parents (including mothers, fathers, grandparents, foster parents, adoptive parents or guardians) from either population or clinical samples (that is, with or without child behavioural problems) with parental responsibility for the day-to-day care of children, and who were eligible to take part in a parent training programme aimed at helping them to address some aspect of parental functioning (for example, attitudes and behaviour).

We included studies of parenting programmes delivered to all parents, not just those at risk of poor psychosocial health and child behavioural problems. Although we are addressing the impact of parenting programmes on aspects of parental psychosocial functioning such as anxiety and depression, we excluded studies that explicitly targeted and thereby focused solely on parents with a diagnosed psychiatric disorder, for example, clinical depression. This reflects the fact that parenting programmes are primarily provided to address children's social, emotional and behavioural functioning, and although parents with clinical psychiatric conditions may benefit from a parenting programme, these would not typically be provided as the primary source of treatment. Parents with clinical psychiatric conditions should be the focus of a separate review. 
We included studies of parents who had children with a disability if the intervention was aimed at supporting or changing parenting and the study also measured parental psychosocial health.

We excluded studies that focused solely on child outcomes, preparation of parents for parenthood or that were directed at pregnant or parenting teenagers (below the age of 20 years).

\subsubsection{Types of interventions}

We included parenting programmes meeting the following criteria:

- group-based format;

- $\quad$ standardised or manualised programme;

- any theoretical framework including behavioural, cognitive and cognitivebehavioural (please see “Description of the intervention”);

- developed largely with the intention of helping parents to manage children's behaviour and improve family functioning and relationships.

We excluded programmes:

- provided to parents on an individual or self-administered basis;

- that involved direct work with children;

- that involved other types of service provision, such as home visits;

- in studies that included only measures of parental attitudes (for example, Parental Attitude Test) or of family functioning (for example, McMaster Family Assessment Device) because, although these may reflect the family's functioning as a group, they are not direct measures of parental psychosocial health.

\subsubsection{Types of outcome measures}

\subsubsection{Primary outcomes}

Outcomes measured using standardised instruments including the measures detailed below.

\subsection{Depressive symptoms}

Parental depressive symptoms measured, for example, through improvement in scores on the Beck Depression Inventory (BDI) (Beck 1961) or similar standardised instrument.

\subsection{Anxiety symptoms}

Parental anxiety measured, for example, through improvement in scores on the Beck Anxiety Inventory (BAI) (Beck 1988) or similar standardised instrument. 


\subsection{Stress}

Parental stress measured, for example, through improvement in scores on the Parenting Stress Index (PSI) (Abidin 1983) or similar standardised instrument.

\subsection{Self-esteem}

Parental self-esteem measured, for example, through improvement in scores on the Rosenberg Self-Esteem scale (RSE) (Rosenberg 1965) or similar standardised instrument.

\subsection{Anger}

Parental anger measured, for example, through improvement in scores on the Brief Anger-Aggression Questionnaire (BAAQ) (Maiuro 1987) or similar standardised instrument.

\subsection{Aggression}

Parental aggression measured, for example, through improvement in scores on the Brief Anger-Aggression Questionnaire (BAAQ) (Maiuro 1987) or similar standardised instrument.

\subsection{Guilt}

Parental guilt measured, for example, through improvement in scores on the Situation of Guilt Scale or similar (SGS) (Klass 1987) or similar standardised instrument.

\subsubsection{Secondary outcomes}

\subsection{Confidence}

Parental confidence measured through improvement in scores on the Parent Sense of Competence Scale (PSC) (J ohnston 1989) or similar standardised instrument.

\subsection{Partner satisfaction}

Marital or partner satisfaction measured through improvement in scores on the Dyadic Adjustment Scale (DAS) (Spanier 1976) or similar standardised instrument.

\subsection{Adverse effects}

Any adverse effects relating to parental psychosocial health including, for example, increase in tension between parents. 


\subsection{SEARCH METHODS FOR IDENTIFICATION OF STUDIES}

\subsubsection{Electronic searches}

The previous version of this review was based on searches run in 2002. This update is based on searches run in 2008, 2010 and 2011. We added the metaRegister of Controlled Trials to search for completed and ongoing trials. We could not update the searches in SPECTR or the National Research Register because they had ceased to exist by 2008. Since the previous version of the review, Sociological Abstracts replaced Sociofile and PsycINFO replaced PsycLIT. During the update, ERIC and Sociological Abstracts moved to new search platforms and the original search strategies were adapted accordingly. All search strategies used for this update are reported in Appendix 1.

We searched the following electronic databases.

- Cochrane Central Register of Controled Trials (CENTRAL), part of the Cochrane Library (2011, Issue 4), last searched 5 December 2011.

- MEDLINE (Ovid) 1950 to November 2011, last searched 5 December 2011.

- $\quad$ EMBASE (Ovid) 1980 to 2011 Week 48, last searched 5 December 2011.

- CINAHL (EBSCO) 1982 to current, last searched 5 December 2011.

- $\quad$ BIOSIS 1970 to 2 December 2011, last searched 5 December 2011.

- $\quad$ PsycINFO 1970 to week 5 November 2011, last searched 5 December 2011.

- Sociological Abstracts (Proquest), 1952 to current, last searched 5 December 2011.

- Sociological Abstracts (CSA), 1963 to current, last searched March 2010.

- Social Science Citation Index, 1956 to 2 December 2011, last searched 5 December 2011.

- $\quad$ ASSIA 1980 to current, last searched 10 November 2011.

- $\quad$ ERIC (via www.eric.ed.gov), 1966 to current, last searched 7 December 2011.

- ERIC (via OVID), 1966 to current, last searched March 2010.

\subsubsection{Searching other resources}

- NSPCC library database (last searched 5 December 2011).

- metaRegister of Controlled Trials (last searched 5 December 2011).

- Reference lists of articles identified through database searches were examined for further relevant studies. We also examined bibliographies of systematic and non-systematic review articles to identify relevant studies. 


\subsection{DATA COLLECTION AND ANALYSIS}

\subsubsection{Selection of studies}

For the first published versions of this review (Barlow 2001; Barlow 2003), we identified titles and abstracts of studies through searches of electronic databases and reviewed the results to determine whether the studies that appeared relevant met the inclusion criteria. For the original review Esther Coren (EC) identified titles and abstracts and these were screened by EC and J B. Two review authors (EC and J B) independently assessed full copies of papers that appeared to meet the inclusion criteria. We resolved uncertainties concerning the appropriateness of studies for inclusion in the review through consultation with a third review author, Sarah Stewart-Brown (SS-B). For the update of the review, Nadja Smailagic (NS) and Nick Huband $(\mathrm{NH})$ carried out the eligibility assessments in consultation with J B and Cathy Bennett (CB). J B had overall responsibility for the inclusion or exclusion of studies in this review.

\subsubsection{Data extraction and management}

Two review authors extracted data independently (J B and EC or SS-B; later NS and $\mathrm{NH}$ ) using a data extraction form and entered the data into Review Manager 5 (RevMan) (RevMan 2011). Where data were not available in the published trial reports, we contacted trial investigators to supply missing information.

Some of the standardised measures used in the studies included in this review are reversed, such that a high score is considered to represent an improvement in outcome. We investigated whether the study investigators had used any methods to correct for this, for example, by reversing the direction of the scale by multiplying the mean values by -1 or by subtracting the mean from the maximum possible for the scale, to ensure that all the scales pointed in the same direction. For data entry into RevMan, we consistently multiplied the mean values by -1 for those scales where a higher score implies lower disease severity, unless this correction had already been made in the published report. Where there was ambiguity about the method of correction, we contacted the study investigators for further information.

\subsubsection{Timing of outcome assessment}

We extracted data for the following time points:

- post-intervention assessment, immediately post-intervention (up to one month following the delivery of the intervention);

- short-term follow-up assessment, two to six months post-intervention;

- long-term follow-up assessment, more than six months post-intervention. 


\subsubsection{Assessment of risk of bias in included studies}

For each included study, three review authors ( $\mathrm{NH}, \mathrm{NS}$ and $\mathrm{HJ}$ ) independently completed the Cochrane Collaboration's tool for assessing risk of bias (Higgins 2008, Section 8.5.1). Any disagreement was resolved in consultation with a third review author (CB). We assessed the degree to which:

- the allocation sequence was adequately generated ('sequence generation');

- the allocation was adequately concealed ('allocation concealment');

- knowledge of the allocated interventions was adequately prevented during the study ('blinding');

- incomplete outcome data were adequately addressed;

- reports of the study were free of suggestion of selective outcome reporting;

- the study was apparently free of other problems that could put it at high risk of bias.

Each domain was allocated one of three possible categories for each of the included studies: low risk of bias, high risk of bias, or 'unclear risk' where the risk of bias was uncertain or unknown.

The first published version of this review used a quality assessment method that we elected not to use in this updated review, instead following guidance from the Cochrane Handbook for Systematic Reviews of Interventions (Higgins 2008) concerning the assessment of risk of bias.

\subsubsection{Measures of treatment effect}

For continuous data that were reported using standardised scales, we calculated a standardised mean difference (effect size) by subtracting the mean post-intervention scores for the intervention and control groups and dividing by the pooled standard deviation.

\subsubsection{Unit of analysis issues}

\subsubsection{Cluster-randomised trials}

The randomisation of clusters can result in an overestimate of the precision of the results (with a higher risk of a Type I error) where their use has not been compensated for in the analysis. Some meta-analyses involved combining data from cluster-randomised trials with data from individually-randomised trials. Five of the included studies were cluster-randomised (Wolfson 1992; Gross 2003; Hiscock 2008; Gross 2009; Hanisch 2010). The impact of the cluster RCTs was explored using a sensitivity analysis (see Sensitivity analysis, below) and we made no adjustments to the data. 


\subsubsection{Cross-over trials}

None of the included studies involved cross-over randomisation.

\subsubsection{Multi-arm trials}

Eleven studies utilised more than one intervention group (Sirbu 1978; Webster Stratton 1988; Spaccerelli 1992; Blakemore 1993; Cunningham 1995; Greaves 1997; Taylor 1998; Gross 2003; Gallart 2005; Gutierrez 2007; Larsson 2009). None of the interventions in these studies were sufficiently similar to be combined to create a single pair-wise comparison, therefore for studies where there was more than one active intervention and only one control group, we selected the intervention that most closely matched our inclusion criteria and excluded the others. In only one study (Gutierrez 2007) was it possible to include both intervention arms in the study without double counting, as a result of the use of a second control group. Gutierrez 2007 compared two parenting programmes: the 1-2-3 Magic Program (classified as behavioural parenting program in our review) and the STEP program (Adlerian, assigned to 'other' types of parenting in our review) against attention placebo (where parents received lectures on topics of interest unrelated to parenting) or a wait-list control condition. In our analyses we compared the behavioural parenting program with the wait-list control group and the STEP program with the attention placebo group.

\subsubsection{Dealing with missing data}

We assessed missing data and dropouts for each included study and we report the number of participants who were included in the final analysis as a proportion of all participants in each study. We provide reasons for missing data in the 'Risk of bias' tables of the 'Characteristics of included studies' section.

We attempted to contact the trial investigators to request missing data and information.

\subsubsection{Assessment of heterogeneity}

We assessed the extent of between-trial differences and the consistency of results of meta-analyses in three ways. We assessed the extent to which there were betweenstudy differences, including the extent to which there were variations in the population group or clinical intervention, or both. We combined studies only if the between-study differences were minor.

We assessed heterogeneity using the $\mathrm{I}^{2}$ statistic. The importance of the observed value of $\mathrm{I}^{2}$ is dependent on themagnitude and direction of effects and strength of evidence for heterogeneity (for example, $\mathrm{P}$ value from the $\mathrm{Chi}^{2}$ test, or a confidence interval for $\mathrm{I}^{2}$ ) (Higgins 2008), and we interpreted $\mathrm{I}^{2}>50 \%$ as evidence of substantial heterogeneity. We also performed the $\mathrm{Chi}^{2}$ test of heterogeneity (where a significance level less than 0.10 was interpreted as evidence of heterogeneity). We 
used a random-effects model as the standard approach and identified significant heterogeneity using subgroup analyses.

\subsubsection{Data synthesis}

The included studies used a range of standardised instruments to measure similar outcomes. For example, depression was measured using the Beck Depression Inventory, the Irritability, Depression and Anxiety Scale and the Centre for Epidemiological Studies Depression Scale. We standardised the results from these different measures by calculating the treatment effect for each outcome in each study and dividing the mean difference in post-intervention scores for the intervention and treatment groups by the pooled standard deviation to produce an effect size. Where appropriate, we then combined the results in a meta-analysis. The decision about whether to combine data in this way was determined by the levels of clinical and statistical heterogeneity present in the population, intervention and outcomes used in the primary studies.

We have presented the effect sizes and 95\% confidence intervals for individual outcomes in individual studies using figures only and have not provided a narrative presentation of individual study results.

\subsubsection{Subgroup analysis and investigation of heterogeneity}

No subgroup analysis was undertaken because there was insufficient evidence of heterogeneity.

\subsubsection{Sensitivity analysis}

At the time of the first update of this review (2003), sensitivity analyses were conducted to assess the impact on the results of the two studies classified as quasirandomised. This was not repeated for the current update since both studies were reclassified as excluded. We conducted a sensitivity analysis to investigate the potential impact of cluster-randomisation methods in five studies. We had planned an a priori sensitivity analyses for studies focusing on children with disabilities, but none of the included studies involved parents of disabled children. 


\section{Results}

\subsection{DESCRIPTION OF STUDIES}

\subsubsection{Results of the search}

The updated electronic searches in J anuary 2008, March 2010 and December 2011 produced 16,609 records. The obvious duplicates were removed by one review author (NS), who inspected the abstracts and discarded 16,477 irrelevant records. Most of articles reviewed were written in English. All studies in languages other than English had abstracts in English and we excluded all these studies on the basis of the information contained in the abstracts, apart from three German studies (Heinrichs 2006; Franz 2007; Naumann 2007), which are awaiting assessment as they need to be translated. We obtained a full text copy of 132 potential included studies and two review authors independently examined each study (NS and $\mathrm{NH}$ ). J B and CB provided advice on any studies about which there was uncertainty.

\subsubsection{Included studies}

This updated review includes 48 studies, 28 of which were published since the previous review (Barlow 2003) that were identified using full text screening against inclusion criteria (Bradley 2003; Gross 2003; Martin 2003; Wolfe 2003; DeGarmo 2004; Farrar 2005; Feliciana 2005; Gallart 2005; Lipman 2005; Treacy 2005; Wang 2005; Chronis 2006; Gardner 2006; Fanning 2007; Fantuzzo 2007; Gutierrez 2007; Hutchings 2007; Matsumoto 2007; Turner 2007; van den Hoofdakker 2007; Hiscock 2008; Gross 2009; Larsson 2009; Morawska 2009; Niccols 2009; Hanisch 2010; J oachim 2010; Matsumoto 2010). Two review authors (NS and NH) independently re-examined the 26 studies included in the previous version of the review against the inclusion criteria and retained 20 of them in this review. Six previously included studies (Van Wyk 1983; Scott 1987; Anastopoulos 1993; Mullin 1994; Sheeber 1994; Zimmerman 1996) were excluded in this update because they did not meet the more rigorous inclusion criteria being applied (see Excluded studies for further details).

We have provided further details about the included studies in the Characteristics of included studies table.

\subsubsection{Design}

All 48 included studies were randomised controlled trials. 
Most studies were two-condition comparisons of group-based parenting programmes against a control group $(\mathrm{n}=37)$. Eleven studies utilised more than one intervention group (Sirbu 1978; Webster Stratton 1988; Spaccerelli 1992; Blakemore 1993; Cunningham 1995; Greaves 1997; Taylor 1998; Gross 2003; Gallart 2005; Gutierrez 2007; Larsson 2009). Gutierrez 2007 compared two parent education programmes (behavioural-based and Adlerian) against two control groups, 'attention placebo' or a wait-list control condition. In our analyses of data from this trial, we compared the behavioural parenting programme with the wait-list control group and the Adlerian programme with the attention placebo group.

Seven studies used a no-treatment control group (Gammon 1991; Schultz 1993; Gross 1995; Greaves 1997; Patterson 2002; DeGarmo 2004; Hanisch 2010); three studies used a treatment-as-usual control group (Fantuzzo 2007; van den Hoofdakker 2007; Hiscock 2008), and three studies used an attention placebo control group (Sirbu 1978; Farrar 2005; Gutierrez 2007). In Farrar 2005 the attention placebo group received information about choosing developmentally appropriate books for their pre-school children; in Gutierrez 2007, which had two control conditions, participants in the 'attention placebo' group were either presented lectures on topics of interest to them, but unrelated to parenting, or assigned to a wait-list control group. In Sirbu 1978, the attention placebo group did not utilise any materials or have a professional leader, and the sessions were unstructured. The remaining 35 studies used only a wait-list control group.

\subsubsection{Cluster-randomised studies}

Five studies were cluster-randomised trials (Wolfson 1992; Gross 2003; Hiscock 2008; Gross 2009; Hanisch 2010). Gross 2003 used day centres as the unit of allocation; in total seven day centres were randomly assigned to one of the three conditions: 'parent training plus teacher condition' $(\mathrm{n}=4)$; 'teacher training condition' ( $\mathrm{n}=4)$, and 'control condition' $(\mathrm{n}=3)$. The control centres received no intervention for at least one year, after which new parents were recruited and the centres were transferred to the 'parent training condition' ( $n=3)$. Hanisch 2010 used kindergartens as the unit of allocation: 58 kindergartens were randomised to the intervention group $(\mathrm{n}=32)$ or to the control group $(\mathrm{n}=26)$. Hiscock 2008 used primary-care nursing centres as the unit of allocation: 40 centres were randomly assigned to the intervention group ( $\mathrm{n}=18$ ) or to the control group ( $\mathrm{n}=22)$. Wolfson 1992 employed randomisation by childbirth class: 25 childbirth classes were randomised but no further details were given.

\subsection{Sensitivity analysis}

The randomisation of clusters can result in an overestimate of the precision of the results (with a higher risk of a Type I error) where their use has not been compensated for in the analysis. We therefore conducted a sensitivity analysis to investigate cluster effects. For this, we assumed the intracluster correlation to be 0.2 , which is much bigger than normally expected. For two of the five cluster-RCTs 
(Wolfson 1992; Hiscock 2008), we only had information about the number of clusters at randomisation and we therefore assumed a worst case scenario using the maximal possible cluster size, taking into account the dropouts during the study. Based on these assumptions, we assessed that the results of the meta-analyses were robust to any clustering effects for most outcomes.

In the worst case scenario there is potential for the confidence interval to widen, depending on the weight of the clustered studies in the meta-analysis. In cases where the effect size is borderline non-significant (for example, analysis 1.1.2), there is potential for the meta-analysis to become borderline significant after the adjustment. Conversely, there is potential for previous significance to be overcome following the adjustment.

In all analyses involving cluster-corrected standard errors, the adjusted effect sizes were equivalent to the unadjusted effect sizes. In addition, in all cases the statistical conclusions were unchanged from the uncorrected to the corrected analyses.

\subsubsection{Sample sizes}

There was considerable variation in sample size between studies. Altogether the 49 included studies initially randomised 4937 participants, with sample sizes ranging from 22 to 733 (mean 102.9; median 60). Five large trials (Irvine 1999; Gross 2003; DeGarmo 2004; Hiscock 2008; Gross 2009) randomised a total of 1830 participants, with sample sizes ranging from 238 to 733 (mean 366; median 292). A further 11 studies (Webster Stratton 1988; Spaccerelli 1992; Cunningham 1995; Taylor 1998; Patterson 2002; Bradley 2003; Lipman 2005; Fantuzzo 2007; Hutchings 2007; Larsson 2009; Hanisch 2010) randomised 1481 participants, with sample sizes ranging from 110 to 198 (mean 134.6; median 126). The remaining 32 studies involved 1626 participants, with sample sizes ranging from 22 to 96 (mean 50.8; median 51).

Seven studies (Sirbu 1978; Gammon 1991; Spaccerelli 1992; Pisterman 1992b; Blakemore 1993; Schultz 1993; Bradley 2003) did not provide sufficient data to calculate effect sizes. The remaining 41 studies included in total 3416 participants with sample sizes ranging from 16 to 671 (mean 83.3; median 82).

\subsubsection{Setting}

Twenty-two studies were conducted in the USA, 10 in Australia, seven in Canada and three in the UK. The remaining studies were conducted in China, Germany, J apan, the Netherlands and New Zealand. Most studies $(n=32)$ were single-centre trials.

In 41 studies, participants were recruited from community settings by a variety of methods including flyers, emails and advertisements directed at parents of young children, or self-referral (Sirbu 1978; Gammon 1991; Spaccerelli 1992; Wolfson 1992; Blakemore 1993; Nixon 1993; Schultz 1993; Gross 1995; J oyce 1995; Odom 
1996; Greaves 1997; Taylor 1998; Webster Stratton 1988; Irvine 1999; McGillicuddy 2001; Nicholson 2002; Bradley 2003; Gross 2003; Martin 2003; Wolfe 2003; DeGarmo 2004; Farrar 2005; Feliciana 2005; Gallart 2005; Lipman 2005; Wang 2005; Chronis 2006; Gardner 2006; Fanning 2007; Fantuzzo 2007; Gutierrez 2007; Hutchings 2007; Matsumoto 2007; Turner 2007; Hiscock 2008; Gross 2009; Morawska 2009; Niccols 2009; Hanisch 2010; J oachim 2010; Matsumoto 2010); in one study from a primary care setting (Patterson 2002); in three studies from outpatient settings including an outpatient mental health clinic (van den Hoofdakker 2007), child psychiatric outpatients departments (Larsson 2009) and from a university-based research clinic (Treacy 2005); in three studies parents were recruited from both community and outpatient settings (Pisterman 1992a; Pisterman 1992b; Cunningham 1995).

The intervention was delivered in outpatient clinics (including research clinics and paediatric outpatient departments) in seven studies (Pisterman 1992a; Pisterman 1992b; Blakemore 1993; Taylor 1998; Treacy 2005; van den Hoofdakker 2007; Larsson 2009); in primary care in one study (Patterson 2002); and in the community in the remaining studies.

\subsubsection{Participants}

An inclusion criterion for this updated review was that participants were parents with responsibility for the day-to-day care of children. In 19 studies, both mothers and fathers were recruited (Webster Stratton 1988; Wolfson 1992; Pisterman 1992a; Pisterman 1992b; Blakemore 1993; Nixon 1993; Schultz 1993; Gross 1995; Taylor 1998; Irvine 1999; McGillicuddy 2001; Wang 2005; Fanning 2007; Hutchings 2007; Matsumoto 2007; van den Hoofdakker 2007; Larsson 2009; Hanisch 2010; Matsumoto 2010). Thirteen studies recruited mothers only (Sirbu 1978; Gammon 1991; Odom 1996; Greaves 1997; Wolfe 2003; DeGarmo 2004; Farrar 2005; Feliciana 2005; Lipman 2005; Chronis 2006; Gutierrez 2007; Hiscock 2008; Niccols 2009). Either the mother or the father was recruited in 12 studies (Spaccerelli 1992; Cunningham 1995; J oyce 1995; Patterson 2002; Bradley 2003; Martin 2003; Gallart 2005; Gardner 2006; Fantuzzo 2007; Turner 2007; Morawska 2009; J oachim 2010). Four studies recruited not only biological parents but also grandparents, foster parents, step parents and relatives (Nicholson 2002; Gross 2003; Treacy 2005; Gross 2009). The studies included in this review were largely directed at mothers, and the trial investigators reported results that were mainly derived from the mothers.

\subsubsection{Interventions}

We provide a description by category of the structure and content of the parenting programmes that were evaluated in the included studies in 'Additional Table 1'. We have grouped the interventions into five categories according to the basic theoretical premise underpinning the programme (for example, behavioural and cognitivebehavioural programmes) or, where there was a sufficient number of studies, 
according to the brand of the programme (Incredible Years and Triple-P parenting programmes). A small group of programmes were unclassifiable (other and nonbranded multimodal programmes). For the purpose of analysis we categorised the studies as below.

\subsection{Behavioural parenting programmes}

Twenty-two studies evaluated the effectiveness of a behavioural parenting programme (Sirbu 1978; Wolfson 1992; Pisterman 1992a; Pisterman 1992b; Blakemore 1993; Cunningham 1995; Odom 1996; Irvine 1999; DeGarmo 2004; Wang 2005; Gutierrez 2007; van den Hoofdakker 2007; Hiscock 2008; Niccols 2009; Hanisch 2010; Martin 2003; Gallart 2005; Matsumoto 2007; Turner 2007; Morawska 2009; J oachim 2010; Matsumoto 2010). This category included programmes which are primarily behavioural in orientation and that are based on social learning principles. These programmes teach parents how to use a range of basic behavioural strategies for managing children's behaviour. Triple-P programmes are included in this category.

\subsection{Cognitive-behavioural parenting programmes}

Nineteen studies evaluated the effectiveness of a cognitive-behavioural parenting programme (Webster Stratton 1988; Gammon 1991; Spaccerelli 1992; Blakemore 1993; Nixon 1993; Gross 1995; J oyce 1995; Greaves 1997; Taylor 1998; McGillicuddy 2001; Nicholson 2002; Patterson 2002; Gross 2003; Lipman 2005; Chronis 2006; Gardner 2006; Hutchings 2007; Gross 2009; Larsson 2009). These programmes combined the basic behavioural type strategies with cognitive strategies aimed at helping parents to identify and change distorted patterns of belief or thought that may be influencing their behaviour. Webster-Stratton Incredible Years programmes were included in this category.

\subsection{Other and multimodal}

It was not possible to classify the interventions from eight studies (Schultz 1993; Wolfe 2003; Farrar 2005; Feliciana 2005; Treacy 2005; Fanning 2007; Fantuzzo 2007; Gutierrez 2007) based on the information provided. See Table 1 for further information about these programmes.

\subsection{Duration of the intervention}

We have described the duration of the intervention as 'standard' in 36 studies (8 to 14 sessions), 'brief' in 10 studies (1 to 6 sessions) and 'long' in two studies (16 weeks or more).

\subsubsection{Outcomes}

All outcomes were parent-report and involved the use of a variety of standardised instruments. We assessed outcomes at three time points: immediately postintervention (up to one month following the delivery of the intervention), short-term 
follow-up (two to six months post-intervention) and long-term follow-up (more than six months post-intervention).

\subsubsection{Primary outcome measures}

\subsection{Depressive symptoms}

Twenty-nine studies assessed the impact of a parent training programme on parental depressive symptoms. Nine studies used the Beck Depression Inventory (Nixon 1993; Cunningham 1995; Taylor 1998; Irvine 1999; McGillicuddy 2001; Treacy 2005; Chronis 2006; Gardner 2006; Hutchings 2007); nine studies used the Depression Anxiety Stress Scale (Martin 2003; Gallart 2005; Matsumoto 2007; Turner 2007; Hiscock 2008; Morawska 2009; Hanisch 2010; J oachim 2010; Matsumoto 2010); six studies used the Center for Epidemiological Studies Depression scale (Gross 1995; Gross 2003; DeGarmo 2004; Lipman 2005; Gross 2009; Niccols 2009); three studies used the Parent Stress Index (Pisterman 1992a; Greaves 1997; Feliciana 2005); Patterson 2002 used the General Health Questionnaire; and Bradley 2003 used the Irritability Depression Anxiety Scale.

\subsection{Anxiety symptoms}

Thirteen studies measured parental anxiety. Most studies $(n=8)$ used the Depression Anxiety Stress Scale (Martin 2003; Gallart 2005; Matsumoto 2007; Hiscock 2008; Morawska 2009; Hanisch 2010; J oachim 2010; Matsumoto 2010); one study used the State-Trait Anxiety Inventory (J oyce 1995); one study (McGillicuddy 2001) used the Brief Symptom Inventory; one (Patterson 2002) used the General Health Questionnaire; and one (Chronis 2006) used the Beck Anxiety Inventory.

\subsection{Stress}

Almost three-quarters $(\mathrm{n}=36$ ) of included studies assessed parental stress using nine scales. Seventeen studies used the Parenting Stress Index (Webster Stratton 1988; Spaccerelli 1992; Pisterman 1992a; Pisterman 1992b; Blakemore 1993; Gross 1995; Greaves 1997; Nicholson 2002; Patterson 2002; Wolfe 2003; Feliciana 2005; Treacy 2005; Wang 2005; Gutierrez 2007; Hutchings 2007; van den Hoofdakker 2007; Larsson 2009); nine studies used the Depression Anxiety Stress Scale (Martin 2003; Gallart 2005; Matsumoto 2007; Turner 2007; Hiscock 2008; Morawska 2009; Hanisch 2010; J oachim 2010; Matsumoto 2010); two studies used the Every Day Stress Index (Gross 2003; Gross 2009); two studies used the modified Uplifts and Hassles Scale (Wolfson 1992; Fantuzzo 2007); and six studies (Sirbu 1978; Gammon 1991; Bradley 2003; Farrar 2005; Chronis 2006; Fanning 2007) used the Brief Symptom Inventory, Perceived Stress Scale, Parental Stress Scale, Confidence Rating Questionnaire, Profile of Mood State and Stress Satisfaction Questionnaire, respectively.

\subsection{Self-esteem}


Three studies (Patterson 2002; Lipman 2005; Chronis 2006) assessed parental selfesteem using the Rosenberg Self-Esteem Scale (Rosenberg 1965).

\subsection{Anger}

Three studies assessed parental anger using the Berger Feeling Scale (J oyce 1995;

Greaves 1997) and the State-Trait Anger Inventory (McGillicuddy 2001).

\subsection{Aggression}

None of the included studies assessed aggression.

\subsection{Guilt}

Three studies measured guilt using the Berger Feeling Scale (Joyce 1995; Greaves 1997) and Situational Guilt Scale (Nixon 1993).

\subsubsection{Secondary outcome measures}

\subsection{Confidence}

One-third $(\mathrm{n}=16)$ of included studies assessed parental confidence and used seven scales or subscales to measure this outcome. Four studies used the Parenting Sense of Competence Scale (Cunningham 1995; Odom 1996; Feliciana 2005; Gardner 2006); four studies used the Problem Setting and Behaviour Checklist (Martin 2003; Matsumoto 2007; Morawska 2009; Matsumoto 2010); three studies used the Toddler Care Questionnaire (Gross 1995; Gross 2003; Gross 2009); two studies used the Parent Stress Index (Pisterman 1992a; Pisterman 1992b); and three studies (Wolfson 1992; Farrar 2005; J oachim 2010) used the Kansas Parent satisfaction Scale, Parenting Task Checklist and Parental Efficacy measures, respectively.

\subsection{Partner satisfaction}

Eight included studies reported partner satisfaction and used five scales to measure this. Three studies (Matsumoto 2007; Morawska 2009; Matsumoto 2010) used the Relationship Quality Index; two studies (Taylor 1998; Chronis 2006) used the Dyadic Adjustment Scale; one study (Pisterman 1992a) used the Parenting Stress Index; one study (Schultz 1993) used the Marital Adjustment Inventory; and one study used the Locke-Wallace Marital Adjustment Scale (Treacy 2005).

\subsection{Adverse effects}

None of the included studies set out to report any adverse effects and none reported any adverse effects.

\subsubsection{Excluded studies}

In this updated review, 121 studies (85 new and 36 from the earlier review) did not meet all the inclusion criteria. We excluded studies from the review if random allocation was not used ( $\mathrm{n}=14$ ), if participants or the control group did not meet the inclusion criteria $(n=28)$, if the intervention was not group-based $(n=34)$, if the study did not focus on parental psychosocial health $(n=54)$, if the study involved 
direct work with children ( $n=9)$ or was a summary of another study $(n=5)$, and if standardised outcome measures were not used (3). We excluded 23 studies because of more than one reason mentioned above. Six excluded studies were listed as included studies in a previous version of the review but are now excluded (Van Wyk 1983; Scott 1987; Anastopoulos 1993; Mullin 1994; Sheeber 1994; Zimmerman 1996). We excluded Anastopoulos 1993, Scott 1987, Sheeber 1994 and Mullin 1994 on the basis that they did not meet the definition of a randomised or quasirandomised trial (Higgins 2008). Anastopoulos 1993 and Mullin 1994 were described as 'quasi-experimental', but on inspection they were pre and post-test studies and no attempt was made to randomly assign the participants to groups. Scott 1987 allocated by group alternation. Sheeber 1994 was a partially randomised trial. We excluded Van Wyk 1983, which reported changes in personality outcomes only, because it did not focus on parental mental health or parenting. Zimmerman 1996 did not focus on parental psychosocial health; the study investigated the influence of parenting skills strategies on family functioning. We have given the reasons for the exclusion of the 121 excluded studies in the Characteristics of excluded studies table.

\subsection{RISK OF BIAS IN INCLUDED STUDIES}

The 'Risk of bias' table provides a summary of our assessment of the risk of bias for the 48 included studies (see Characteristics of included studies and Figure 1). Each risk of bias table provides a decision about the adequacy of the study in relation to the criterion, summarised as 'low risk of bias'; 'high risk of bias' and 'unclear risk of bias' (Higgins 2008). We attempted to contact the investigators where insufficient information was provided and we succeeded in obtaining further information for 22 studies.

\subsubsection{Allocation (selection bias)}

The method of sequence generation was adequate in 24 studies: 18 studies used allocation based on random numbers that were computer-generated or derived from a table (Cunningham 1995; Gross 1995; Irvine 1999; McGillicuddy 2001; Nicholson 2002; Gross 2003; DeGarmo 2004; Farrar 2005; Lipman 2005; Gardner 2006; Hutchings 2007; Turner 2007; van den Hoofdakker 2007; Hiscock 2008; Gross 2009; Morawska 2009; Niccols 2009; J oachim 2010); four studies used allocation by drawing lots from a hat (Webster Stratton 1988; Odom 1996; Gallart 2005; Hanisch 2010); two studies allocated participants by throwing a dice or coin flipping (Patterson 2002; Wang 2005). We classified adequacy of sequence generation as 'unclear' in the 24 remaining studies.

We assessed that allocation was adequately concealed in 14 studies (Webster Stratton 1988; Cunningham 1995; Gross 1995; Odom 1996; Irvine 1999; McGillicuddy 2001; Patterson 2002; Farrar 2005; Lipman 2005; Gardner 2006; Turner 2007; van den Hoofdakker 2007; Hiscock 2008; Niccols 2009). Six studies 
(Nicholson 2002; Gross 2003; Gallart 2005; Wang 2005; Gross 2009; Morawska 2009) reported that allocation was not adequately concealed. We classified adequacy of allocation sequence as 'unclear' in the 28 remaining studies.

\subsubsection{Blinding (performance bias and detection bias)}

We judged that it would not be possible to fully blind participants in studies of the type included in this review. We found no indication of any specific additional measures taken to reduce the risk of bias in the majority of included studies ( $\mathrm{n}=$ 45). Farrar 2005 reported that one assessor was assigned to each group in order to ensure that participants did not have contact with members of the other group. Gallart 2005 reported that participants were kept blind to the fact that there were two different formats of the programme. Sirbu 1978 attempted to ensure that participants were unaware of the type of intervention they were receiving. However, review authors judged that those specific measures were not sufficient to reduce the risk of bias.

Trial investigators reported that outcome assessors were blind to the allocation status of participants in 15 studies (Blakemore 1993; Cunningham 1995; Gross 1995; Odom 1996; Webster Stratton 1988; Irvine 1999; McGillicuddy 2001; Patterson 2002; DeGarmo 2004; Gardner 2006; Fanning 2007; Fantuzzo 2007; Turner 2007; Hiscock 2008; Niccols 2009). In eight studies, outcome assessors were either not blinded or blinding was compromised during the trial (Taylor 1998; Farrar 2005; Gallart 2005; Lipman 2005; Wang 2005; Matsumoto 2007; Morawska 2009; Hanisch 2010). We classified the blinding of outcome assessors as 'unclear' in the remaining 25 studies.

\subsubsection{Incomplete outcome data (attrition bias)}

We judged that most of the studies $(\mathrm{n}=32)$ adequately addressed incomplete outcome data; eight of those studies (Blakemore 1993; Greaves 1997; McGillicuddy 2001; Nicholson 2002; Wolfe 2003; Feliciana 2005; Fantuzzo 2007; Matsumoto 2007) reported that none of the participants dropped out and the study data were collected on all participants at each data collection point; four studies (Gross 1995; Gross 2003; Martin 2003; Larsson 2009) did not adequately address incomplete outcome data; the remaining 12 studies were classified as 'unclear'.

\subsubsection{Selective reporting (reporting bias)}

Most studies ( $\mathrm{n}=44$ ) appeared to have included all expected outcomes and were free of selective reporting. Four studies were not free of selective reporting: Bradley 2003 did not report endpoint and follow-up data for depressive symptoms from the BSI subscale; Gross 2009 stated that three outcomes (depressive symptoms, stress and confidence) were not included in the paper because of length and their lack of association with the outcome variables; Turner 2007 did not report scores for the anxiety scale of the DASS; Wolfe 2003 did not report endpoint and follow-up data for the parent-child dysfunctional interaction subscale of the PSI. 


\subsubsection{Other potential sources of bias}

While the use of randomisation should in theory ensure that any possible confounders are equally distributed between the arms of the trial, the randomisation of small numbers of respondents may result in an unequal distribution of confounding factors. It is therefore important that the distribution of known potential confounders is: (i) compared between the different study groups at the outset, or (ii) adjusted for at the analysis stage.

Spaccerelli 1992 used two newly developed measures, which also raised the possibility of bias. Hutchings 2007 reported a competing interest as both author and provider of occasional parent training courses. The remaining 46 studies appeared to be free of other bias.

\subsection{EFFECTS OF INTERVENTIONS}

In the text below, an I2 value for heterogeneity was only reported if it exceeded $50 \%$ or if the $\mathrm{P}$ value from the Chi2 test was $<0.05$. Numbers given are the total number of participants randomised. Where it has been possible to calculate an effect size, we have reported these with 95\% confidence intervals (CI). Where we calculated and reported effect sizes, a minus sign indicates that the results favour the intervention group. Where the calculated effect size is statistically significant $(\mathrm{P}<0.05)$, we state whether the result favours the intervention or control condition.

In terms of effect sizes, values $>0.70$ have been treated as large; those between 0.40 and 0.70 as moderate; values $<0.40$ and $>0.10$ have been treated as small; and values $<0.10$ have been treated as no evidence of effectiveness (Higgins 2008, Section 12.6.2).

We have summarised the results below under headings corresponding to the seven primary and the three secondary outcomes outlined in the section entitled Types of outcome measures. For each outcome, we have presented the results according to the timing of the outcome assessment. Three categories of outcome assessment were used: post-intervention (up to four weeks after the end of the intervention), shortterm follow-up (two to six months post-intervention), and long-term follow-up (more than six months post-intervention). Under each heading, results of subgroup analyses (to compare types of intervention) are included where these were conducted. For clarity, results of two further subgroup analyses (impact of paternalonly outcomes; impact of duration of intervention) are summarised in a separate section.

\subsubsection{Primary outcomes}

\subsubsection{Depressive symptoms}

\subsection{Post-intervention}


Meta-analysis of data from 22 studies revealed a statistically significant difference between intervention and control conditions, favouring the intervention (SMD - 0.17, CI -0.28 to $-0.07, \mathrm{P}=0.001, \mathrm{n}=1591, \mathrm{I} 2=7 \%$, Analysis 1.1 .1 ). This result was broadly consistent with the meta-analysis of 11 studies reported in the previous version of this review (SMD -0.26) (Barlow 2003).

\subsection{Short-term follow-up}

Meta-analysis of data from 13 studies indicated no statistically significant difference between intervention and control conditions at short-term follow-up (Analysis 1.1.2). In the previous version of this review, meta-analysis of six studies similarly failed to achieve statistical significance (95\% CI -0.40 to 0.002) (Barlow 2003).

\subsection{Long-term follow-up}

Meta-analysis of data from seven studies revealed no statistically significant difference between intervention and control conditions at long-term follow-up (Analysis 1.1.3).

\subsubsection{Anxiety symptoms}

\subsection{Post-intervention}

Meta-analysis of data from nine studies revealed a statistically significant difference between intervention and control conditions favouring the intervention (SMD -0.22, CI -0.43 to $-0.01, \mathrm{P}=0.04, \mathrm{n}=464, \mathrm{I} 2=22 \%$, Analysis 1.2.1). The previous version of this review did not report an analysis for anxiety symptoms alone, although a statistically significant effect favouring the intervention was identified for the combined outcome of anxiety and stress (SMD -0.4, 95\% CI -0.6 to -0.2) (Barlow 2003).

\subsection{Short-term follow-up}

Meta-analysis of data from three studies indicated no statistically significant difference between intervention and control conditions at short-term follow-up (Analysis 1.2.2).

\subsection{Long-term follow-up}

Meta-analysis of data from two studies at long-term follow-up indicated no statistically significant difference between intervention and control conditions (Analysis 1.2.3).

\subsubsection{Stress}

\subsection{Post-intervention}

Meta-analysis of data from 25 studies, which included data from both arms (behavioural versus wait-list control, Adlerian parent training versus attention 
placebo control) and both control conditions for Gutierrez 2007, revealed a statistically significant difference between intervention and control conditions favouring the intervention (SMD - $0.29,95 \% \mathrm{CI}-0.42$ to $-0.15, \mathrm{P}<0.0001, \mathrm{n}=1567$, Analysis 1.3.1) but with evidence of significant heterogeneity ( $\mathrm{I} 2=35 \% ; \mathrm{P}=0.04$ ). The previous version of this review did not report an analysis for stress symptoms alone, although a statistically significant effect was found for the combined outcome of anxiety and stress, again favouring the intervention (SMD - 0.4, 95\% CI - 0.6 to $0.2,10$ studies).

\subsection{Short-term follow-up}

Meta-analysis of data from 12 studies again indicated a statistically significant difference between intervention and control conditions favouring the intervention (SMD -0.22, 95\% CI -0.42 to -0.01, $\mathrm{P}=0.04, \mathrm{n}=1680$, Analysis 1.3.2) but with evidence of statistically significant heterogeneity (I2 =69\%; $\mathrm{P}<0.0001$ ). One possible reason for the large I2 value is that the impact of parent training on stress scores varied with the modality of the intervention (see below).

\subsection{Long-term follow-up}

Meta-analysis of data from four studies at long-term follow-up indicated no statistically significant difference between intervention and control conditions (Analysis 1.3.3).

\subsubsection{Self-esteem}

\subsection{Post-intervention}

Meta-analysis of data from two studies at post-intervention indicated no statistically significant difference between intervention and control conditions (Analysis 1.4.1).

\subsection{Short-term follow-up}

Meta-analysis of data from two studies at short-term follow-up indicated no statistically significant difference between intervention and control conditions (Analysis 1.4.2).

\subsection{Long-term follow-up}

Meta-analysis of data from two studies at long-term follow-up indicated no statistically significant difference between intervention and control conditions (Analysis 1.4.3).

\subsubsection{Anger}

\subsection{Post-intervention}


Meta-analysis of data from three studies revealed a statistically significant difference between intervention and control conditions favouring the intervention (SMD -0.60, $95 \% \mathrm{CI}-1.00$ to $-0.20, \mathrm{P}=0.004, \mathrm{n}=107, \mathrm{I}^{2}=0 \%$, Analysis 1.5.1).

\subsection{Short- and long-term follow-up}

Anger was not reported in any study at short- or long-term follow-up.

\subsubsection{Aggression}

No study reported aggression.

\subsubsection{Guilt}

\subsection{Post-intervention}

Meta-analysis of data from three studies showed a statistically significant difference between intervention and control conditions favouring the intervention (SMD -0.79, $95 \%$ CI -1.18 to $-0.41, \mathrm{P}<0.0001, \mathrm{n}=119, \mathrm{I} 2=0 \%$, Analysis 1.6.1).

\subsection{Short- and long-term follow-up}

No study reported guilt at short- or long-term follow-up.

\subsubsection{Secondary outcomes}

\subsubsection{Confidence}

\subsection{Post-intervention}

Meta-analysis of data from 14 studies revealed a statistically significant difference between intervention and control conditions favouring the intervention (SMD -0.34, 95\% CI - 0.51 to $-0.17, \mathrm{P}<0.0001, \mathrm{n}=1001, \mathrm{I} 2=36 \%$, Analysis 1.7.1).

\subsection{Short-term follow-up}

Meta-analysis of data from seven studies revealed a statistically significant difference between intervention and control conditions favouring the intervention (SMD -0.32, 95\% CI -0.63 to -0.01, $\mathrm{P}=0.04, \mathrm{n}=636$, Analysis 1.7.2) but with evidence of significant heterogeneity ( $\mathrm{I} 2=68 \% ; \mathrm{P}=0.005)$.

\subsection{Long-term follow-up}

Meta-analysis of data from two studies at long-term follow-up indicated no statistically significant difference between intervention and control conditions (Analysis 1.7.3).

\subsubsection{Partner satisfaction}

\subsection{Post-intervention}


Meta-analysis of data from nine studies revealed a moderate, statistically significant difference between intervention and control conditions favouring the intervention (SMD -0.28, 95\% CI -0.47 to -0.09, $\mathrm{P}=0.005, \mathrm{n}=432, \mathrm{I} 2=0 \%$, Analysis 1.8.1). This was consistent with the meta-analysis of four studies reported in the previous version of this review (Barlow 2003), which produced an SMD of -0.4.

\subsection{Short-term follow-up}

At short-term follow up, results of analysis of data from a single study indicated no statistically significant difference between intervention and control conditions (Analysis 1.8.2).

\subsection{Long-term follow-up}

No study reported partner satisfaction at short- or long-term follow-up.

\subsubsection{Adverse effects}

No study reported adverse effects.

\subsubsection{Paternal outcome measures}

Only four studies reported outcome data from fathers separately. These data were available for four outcomes (depressive symptoms, stress, confidence, and partner satisfaction) but with meta-analysis possible for the outcome of stress only. Metaanalysis of data from four studies for paternal stress at post-intervention revealed a statistically significant difference between intervention and control conditions favouring the intervention (SMD $-0.43,95 \% \mathrm{CI}-0.79$ to $-0.06, \mathrm{P}=0.02, \mathrm{n}=123, \mathrm{I}^{2}=$ $0 \%$, Analysis 2.42.1). This effect size is larger than the overall figure (for mothers and for both parental figures) obtained in Analysis 1.3.1(SMD -0.29). Examining data from individual studies revealed no statistically significant effect from paternalonly data for depressive symptoms, confidence or partner satisfaction (Analysis 2.40.1; Analysis 2.41.1; Analysis 2.43.1; Analysis 2.44.1). 


\section{Discussion}

\subsection{SUMMARY OF MAIN RESULTS}

This updated review includes a total of 48 studies. Eight meta-analyses were conducted evaluating the immediate post-intervention impact and four evaluating the short-term (six months) and long-term (one year or more) impact of behavioural ( $n=22)$, cognitive-behavioural $(n=19)$ and non-classifiable or multimodal $(n=8)$ parenting programmes on a range of aspects of parental psychosocial wellbeing. The results indicate that parenting programmes were effective immediately postintervention in producing statistically significant improvements in a number of aspects of parental psychosocial functioning including depression (SMD -0.17, 95\% CI -0.28 to -0.07); anxiety (SMD - 0.22, 95\% CI - 0.43 to - 0.01); stress (SMD -0.29, 95\% CI -0.42 to -0.15); anger (SMD -0.60, 95\% CI - 1.00 to -0.20); guilt (SMD - 0.79, $95 \%$ CI - 1.18 to -0.41); confidence (SMD - $0.34,95 \%$ CI -0.51 to -0.17 ), and satisfaction with the partner relationship (SMD -0.28, 95\% CI -0.47 to -0.09). There was, however, evidence of significant statistical heterogeneity for the meta-analyses of stress outcomes post-intervention and for parental confidence at short-term follow-up.

Although the results suggest that stress (SMD -0.22, 95\% CI - 0.42 to - 0.01 ) and confidence (SMD - $0.32,95 \%$ CI - 0.63 to - 0.01 ) continued to be statistically significant at six month follow-up, none of the outcomes measured remained statistically significant at one year. This finding strongly points to the need for parents to receive 'top ups' or post-intervention support to help them to maintain the short-term benefits.

There were only sufficient data from fathers to conduct one meta-analysis. This showed a statistically significant short-term improvement in paternal stress (SMD $0.43,95 \%$ CI - 0.79 to -0.06). The deleterious consequences of compromised paternal psychosocial functioning has now been clearly recognised (for example, Kane 2004; Ramchandani 2008), and the need to support fathers has been highlighted at policy level (Department of Health 2009). This finding points to the need for further research focusing explicitly on the impact of such programmes on the psychosocial functioning of fathers. 


\subsection{OVERALL COMPLETENESS AND APPLICABILITY OF EVIDENCE}

These data provide a comprehensive picture about the impact of the key types of parenting programme (for example, behavioural and cognitive-behavioural) on parental psychosocial functioning.

The studies were conducted in a wide range of settings and countries including the USA, Australia, Canada, UK, China, Germany, J apan, the Netherlands and New Zealand.

Only a small number of studies examined the effectiveness of parenting programmes in terms of the psychosocial functioning of fathers, and this is a serious omission given that fathers now play a significant role in childcare, and research suggests that their psychosocial functioning is key to the wellbeing of children (see Background).

\subsection{QUALITY OF THE EVIDENCE}

The overall quality of the included studies is summarised in Figure 1. Many studies were unclear about important quality criteria, including allocation concealment, sequence generation and blinding. We examined the included studies for evidence of other potential biases, including that of conflict of interest, which was implicated in one study only (Hutchings 2007) where the study author also delivered the intervention. A number of the included studies (in particular the Webster-Stratton and Triple-P programmes) involved the programme developer in the evaluation.

\subsection{POTENTIAL BIASES IN THE REVIEW PROCESS}

In the original review we estimated the standardised mean difference by calculating the treatment effect for each outcome in each study by dividing the mean difference in post-intervention scores for the intervention and treatment groups by the pooled standard deviation. To promote consistency we have continued with this method. It should be noted, however, that random allocation does not guarantee equality of means between groups at pre-test, and also that post-test standard deviation (SD) may be inflated by a differential response to intervention, and may underestimate the effect size attributable to the intervention.

\subsection{AGREEMENTS AND DISAGREEMENTS WITH OTHER STUDIES OR REVIEWS}

These findings are consistent with the earlier review (Barlow 2003) of the effectiveness of parent training programmes in improving the psychosocial wellbeing of parents. However, the significant addition of new studies has enabled us to reach a number of new conclusions in terms of the evidence about effectiveness 
being limited to standard ( 10 to 12 week) parent training programmes and in the short term only. This is largely consistent with the findings of reviews that examine the impact of parenting programmes on children's behaviour, which is again mostly limited to evidence of short-term benefits (Dretze 2005; Barlow 2011). 


\section{Authors' conclusions}

\subsection{IMPLICATIONS FOR PRACTICE}

This review provides sufficient evidence to support the use of parenting programmes to improve parental psychosocial functioning. However, the findings also suggest that the benefits are short-term and that parents may need additional support if the improvements are to be maintained over time. Although there is insufficient

evidence to clearly demonstrate an impact on paternal psychosocial functioning, the limited evidence available suggests that parenting programmes have potential to improve the psychosocial functioning of fathers as well as mothers. Evidence about the importance of paternal psychosocial functioning on the wellbeing of children, alongside numerous policy directives pointing to the need to provide better support for fathers, suggest that parenting programmes should also be offered to fathers.

\subsection{IMPLICATIONS FOR RESEARCH}

Only a small number of studies examined the effectiveness of parenting programmes in terms of the psychosocial functioning of fathers, and this is a serious omission given that fathers now play a significant role in childcare and research suggests that their psychosocial functioning is key to the wellbeing of children (see Background). The findings also suggest that effectiveness is limited to the short term only and future research should as such address the reasons for this, including the need for longer or more intensive programmes or for post-intervention support. Further research is also needed to identify whether brief programmes can impact on parental wellbeing.

These results do not enable us to address whether parenting programmes bring about improvements in some aspects of parental psychosocial functioning as a consequence of improvements in children's behaviour and family functioning more generally, or as a result of strategies within the programmes explicitly targeting parental psychosocial functioning. This finding warrants explicit examination as part of future research on parenting programmes. 


\section{Acknowledgements}

We thank Esther Coren for her work as author of the previously published versions of the review and for her advice on this update. We also thank Sarah Stewart-Brown for her work as an author on the original review.

We thank the editorial team of the Cochrane DPLP Group (J ane Dennis, Chris Champion, Laura MacDonald, J o Abbott and Margaret Anderson) for their support and advice.

We thank J ulian Higgins (MRC Biostatistics Unit, Cambridge) who gave advice about the analysis plan.

CB thanks the University of Bristol and Queen's University Belfast for awarding visiting fellowships to support her in the academic activities of writing this review between 2008 and 2012. 


\section{Differences between protocol and review}

- We changed the title from 'maternal' to 'parental'.

- We updated the Background and Discussion text.

- We clarified the participants, i.e. specified that parents with disabled children were included.

- We clarified that we excluded studies that explicitly targeted and thereby focused solely on parents with a specific psychiatric disorder, including for example clinical depression. We also excluded studies that focused solely on child outcomes, or were focused on preparation for parenthood, or were studies with participants who were pregnant or parenting teenagers (below the age of 20), and studies with mixed age groups where data were not presented separately for adult and teenage parents. We excluded studies which did not focus on parental mental health or parenting. This is not a change but was not explicitly described in the previous published version of the review.

- Outcomes change to primary and secondary. We clarified the types of outcomes included in the term 'parental psychosocial health'. In the previous published version of the review perception of parenting skills as an outcome was implied but not specified as such in the list of outcomes, this has now been clarified. No new outcomes other than adverse effects.

- Quasi-randomised trials were defined as those where the participants were assigned to treatment groups on the basis of alternate allocation (Higgins 2008) but not if they were described as quasi-experimental and were of a preand post-test design. In this updated version of the review we re-assessed two studies (Anastopoulos 1993; Mullin 1994) that were previously categorised as quasi-randomised and excluded them on the basis that they did not involve alternate allocation.

- We conducted analyses based on the duration of the interventions and the type of intervention.

- We updated the Methods section to take into account Risk of Bias assessments.

- Criteria for considering studies for this review. We specified in more detail the types of participant, interventions and types of studies. 
- Unit of analysis issues. We updated the Methods section for dealing with cluster randomised trials. We added a section about dealing with multi-arm trials.

- Timing of outcome assessment. We clarified the time points in the Methods section. Although these were implied in the previous published versions of the review, it was not clearly stated that these time points were prospectively applied to data extraction. Data were extracted for the following time points, post-intervention assessment: any time from immediate post intervention to up to 4 weeks post-intervention; short-term follow-up assessment: one to six months post-intervention; long-term assessment: > six months postintervention. 


\section{Characteristics of studies}

\subsection{CHARACTERISTICS OF INCLUDED STUDIES}

\subsubsection{Blakemore 1993}

\begin{tabular}{|c|c|}
\hline Methods & Parallel randomised controlled trial. \\
\hline Participants & $\begin{array}{l}\text { Participants: volunteers or professionally referred parents of children with ADHD. } \\
\text { Sex: } 24 \text { mothers; } 24 \text { fathers. } \\
\text { Age of participants: not stated. } \\
\text { Unit of allocation: individual family. } \\
\text { Number randomised: } 24 \text { families per year (8 group-based intervention; } 8 \text { individual-based intervention; } \\
8 \text { control). } \\
\text { Number used in analysis: number available for analysis n=16 (8 intervention; } 8 \text { control)* } \\
\text { Country \& setting: Canada; single-site; recruited from community settings; intervention delivered in an } \\
\text { outpatient clinic. } \\
\text { Inclusion criteria: parents with at least one child aged } 6 \text { to } 11 \text { years with evidence of ADHD in a wide } \\
\text { range of situations; ADHD evident before the age of six. } \\
\text { Exclusion criteria: a serious neurological difficulties; Conduct Disorder in the child with ADHD; a } \\
\text { serious marital difficulties. } \\
\text { Ethnicity: not stated. } \\
\text { Baseline characteristics: not stated. }\end{array}$ \\
\hline Interventions & $\begin{array}{l}\text { Three conditions: Cognitive-behavioural parenting programme; Individual-based parent programme; } \\
\text { wait-list control. } \\
\text { Duration of intervention: } 12 \text { weeks; two additional sessions delivered at three and six months after the } \\
\text { termination of initial } 12 \text { sessions. } \\
\text { Length of follow-up: none. }\end{array}$ \\
\hline Outcomes & Stress (Parenting Stress Index)*. \\
\hline Notes & $\begin{array}{l}\text { *Insufficient data to calculate effect sizes. We requested clarification from the trial investigators but no } \\
\text { further information was available at the time this review was prepared. }\end{array}$ \\
\hline
\end{tabular}




\section{Risk of bias table}

\begin{tabular}{|c|c|c|}
\hline Bias & $\begin{array}{l}\text { Authors' } \\
\text { judgement }\end{array}$ & Support for judgement \\
\hline $\begin{array}{l}\text { Random sequence generation (selection } \\
\text { bias) }\end{array}$ & Unclear Risk & $\begin{array}{l}\text { Information reported insufficient for a judgement to be } \\
\text { made. We requested clarification from the trial } \\
\text { investigators, but no further information was available at } \\
\text { the time this review was prepared. }\end{array}$ \\
\hline Allocation concealment (selection bias) & Unclear Risk & $\begin{array}{l}\text { Information reported insufficient for a judgement to be } \\
\text { made. We requested clarification from the trial } \\
\text { investigators, but no further information was available at } \\
\text { the time this review was prepared. }\end{array}$ \\
\hline $\begin{array}{l}\text { Blinding (performance bias and detection } \\
\text { bias) } \\
\text { Participants }\end{array}$ & High Risk & $\begin{array}{l}\text { Review authors judged that it would not be possible to } \\
\text { fully blind participants in this type of study, and found no } \\
\text { indication of any specific additional measures taken to } \\
\text { reduce the risk of bias that might result from differential } \\
\text { behaviours by participants. }\end{array}$ \\
\hline $\begin{array}{l}\text { Blinding (performance bias and detection } \\
\text { bias) } \\
\text { Personnel }\end{array}$ & High Risk & $\begin{array}{l}\text { Review authors consider the design of study means } \\
\text { personnel would be aware which groups had been } \\
\text { assigned to two study conditions. }\end{array}$ \\
\hline $\begin{array}{l}\text { Blinding (performance bias and detection } \\
\text { bias) } \\
\text { Outcome assessors }\end{array}$ & Low Risk & $\begin{array}{l}\text { Investigators report that participants were "presented } \\
\text { with a structured interview by a research assistant who } \\
\text { is blind to the treatment status of the parent" (page 80). } \\
\text { Review authors consider the outcome assessor was } \\
\text { blinded and that the non-blinding of others was unlikely } \\
\text { to have introduced bias. }\end{array}$ \\
\hline Incomplete outcome data (attrition bias) & Low Risk & $\begin{array}{l}\text { Investigators report that the data presented "were } \\
\text { obtained during the first year of the project with } 24 \\
\text { subjects (8 subjects in each of the three treatment } \\
\text { conditions)" (page 81). There was no missing data. }\end{array}$ \\
\hline Selective reporting (reporting bias) & Low Risk & $\begin{array}{l}\text { Review authors judge that the published report includes } \\
\text { all expected outcomes, including those that were pre- } \\
\text { specified. }\end{array}$ \\
\hline Other bias & Low Risk & The study appeared to be free of other sources of bias. \\
\hline
\end{tabular}




\subsubsection{Bradley 2003}

\begin{tabular}{|c|c|}
\hline Methods & Parallel randomised controlled trial. \\
\hline Participants & $\begin{array}{l}\text { Participants: parents of preschoolers with behavioural problems, recruited through advertisements } \\
\text { placed in community locations. } \\
\text { Sex: } 184 \text { mothers; } 14 \text { fathers. } \\
\text { Age of parents: mean } 35.20 \text { years (SD 5.51) intervention; mean } 35.88 \text { years (SD } 5.73 \text { ) control. } \\
\text { Unit of allocation: individual participant. } \\
\text { Number randomised: } 198 \text { (89 intervention; } 109 \text { control). } \\
\text { Number used in analysis: number available for analysis n=174 ( } 81 \text { intervention; } 93 \text { control)*. } \\
\text { Country \& setting: Canada; multi-site (number unclear); recruited from community settings; } \\
\text { intervention delivered in the community. } \\
\text { Inclusion criteria: parents experiencing problems managing the behaviour of their } 3 \text { or } 4 \text { year old } \\
\text { children. } \\
\text { Exclusion criteria: not stated. } \\
\text { Ethnicity: not stated. } \\
\text { Baseline characteristics: described as largely middle-class parents; >80\% had post-secondary } \\
\text { education; significantly more boys (121) than girls ( } 77) ; \text { no significant differences between } \\
\text { experimental and control groups on age of parents, age of child, or intactness of family. }\end{array}$ \\
\hline Interventions & $\begin{array}{l}\text { Two conditions: Psychoeducational programme with videotape modelling (behavioural parenting } \\
\text { programme); wait-list control. } \\
\text { Duration of intervention: } 7 \text { weeks. } \\
\text { Length of follow-up: } 12 \text { months. }\end{array}$ \\
\hline Outcomes & $\begin{array}{l}\text { Depressive symptoms (Brief Symptom Inventory)*. } \\
\text { Stress (Brief Symptom Inventory)*. }\end{array}$ \\
\hline Notes & $\begin{array}{l}\text { *Insufficient data to calculate effect sizes. Clarification was requested from the trial investigators but } \\
\text { no further information was available at the time this review was prepared. }\end{array}$ \\
\hline
\end{tabular}

\section{Risk of bias table}

\begin{tabular}{lll}
\hline Bias & $\begin{array}{l}\text { Authors' } \\
\text { judgement }\end{array}$ & Support for judgement \\
\hline $\begin{array}{l}\text { Random sequence generation (selection } \\
\text { bias) }\end{array}$ & Unclear Risk & $\begin{array}{l}\text { Information reported insufficient for a judgement to be } \\
\text { made. We requested clarification from the trial } \\
\text { investigators, but no further information was available at } \\
\text { the time this review was prepared. }\end{array}$ \\
\hline Allocation concealment (selection bias) & Unclear Risk & $\begin{array}{l}\text { Information reported insufficient for a judgement to be } \\
\text { made. We requested clarification from the trial }\end{array}$ \\
& & $\begin{array}{l}\text { investigators, but no further information was available at } \\
\text { the time this review was prepared. }\end{array}$ \\
\cline { 2 - 3 }
\end{tabular}




\begin{tabular}{|c|c|c|}
\hline Bias & $\begin{array}{l}\text { Authors' } \\
\text { judgement }\end{array}$ & Support for judgement \\
\hline $\begin{array}{l}\text { Blinding (performance bias and detection } \\
\text { bias) } \\
\text { Participants }\end{array}$ & High Risk & $\begin{array}{l}\text { Review authors judged that it would not be possible to } \\
\text { fully blind participants in this type of study, and found no } \\
\text { indication of any specific additional measures taken to } \\
\text { reduce the risk of bias that might result from differential } \\
\text { behaviours by participants. }\end{array}$ \\
\hline $\begin{array}{l}\text { Blinding (performance bias and detection } \\
\text { bias) } \\
\text { Personnel }\end{array}$ & Unclear Risk & $\begin{array}{l}\text { Information reported insufficient for a judgement to be } \\
\text { made. We requested clarification from the trial } \\
\text { investigators, but no further information was available at } \\
\text { the time this review was prepared. }\end{array}$ \\
\hline $\begin{array}{l}\text { Blinding (performance bias and detection } \\
\text { bias) } \\
\text { Outcome assessors }\end{array}$ & Unclear Risk & $\begin{array}{l}\text { Information reported insufficient for a judgement to be } \\
\text { made. We requested clarification from the trial } \\
\text { investigators, but no further information was available at } \\
\text { the time this review was prepared. }\end{array}$ \\
\hline Incomplete outcome data (attrition bias) & Low Risk & $\begin{array}{l}\text { Data for } 8 / 89(9 \%) \text { missing from the intervention } \\
\text { condition, and for } 16 / 89(15 \%) \text { from the control } \\
\text { condition. Reasons for dropout not given. Overall } \\
\text { attrition was } 11.8 \% \text { at post-intervention. Review authors } \\
\text { considered the numbers of and reasons for missing } \\
\text { data reasonably likely to be balanced across the } \\
\text { treatment conditions. }\end{array}$ \\
\hline Selective reporting (reporting bias) & High Risk & $\begin{array}{l}\text { Investigators do not report endpoint / follow-up data for } \\
\text { depressive symptoms from the BSI subscale outcomes. } \\
\text { Clarification has been requested, but the trial } \\
\text { investigators (email from SJ Bradley to CB on 07/07/10) } \\
\text { states that they "are unable to find the data". }\end{array}$ \\
\hline Other bias & Low Risk & The study appeared to be free of other sources of bias. \\
\hline
\end{tabular}




\subsubsection{Chronis 2006}

\begin{tabular}{|c|c|}
\hline Methods & Parallel randomised controlled trial. \\
\hline Participants & $\begin{array}{l}\text { Participants: mothers of child aged } 5 \text { to } 13 \text { years with ADHD who were already enrolled in the } \\
\text { Summer Treatment Program. } \\
\text { Sex: all mothers. } \\
\text { Age of parents: mean } 43.2 \text { years (SD 5.0) intervention; } 40.6 \text { years (SD 7.5) control. } \\
\text { Unit of allocation: individual participant. } \\
\text { Number randomised: } 62 \text { (33 intervention; } 29 \text { control). } \\
\text { Number used in analysis: } 51 \text { (25 intervention; } 26 \text { control). } \\
\text { Country \& setting: USA; single-site; recruited from community settings; intervention delivered in the } \\
\text { community. } \\
\text { Inclusion criteria: mother of a child with ADHD who had recently completed 'an intensive behavioural } \\
\text { program targeting their child behaviour' (the ADHD Summer Treatment Program). } \\
\text { Exclusion criteria: not stated. } \\
\text { Ethnicity: children Caucasian } 100 \% \text { intervention group; } 92.3 \% \text { control group. } \\
\text { Baseline characteristics: } \\
\text { (mothers): } 21 / 62 \text { (34\%) lifetime history of major depressive disorder; } 2 / 62 \text { (3\%) experiencing current } \\
\text { major depressive episode at time of intake; mean HDRS score at intake } 5.6 \text { (SD 4.6) intervention and } \\
5.2 \text { (SD 4.4) controls; taking antidepressants 32\% intervention and 19\% controls; (children): } 100 \% \\
\text { ADHD; adopted 4\% intervention and 7.7\% controls; IQ 107.4 (SD16.07) intervention and } 99.0 \text { (SD } \\
28.7) \text { controls; } 11.8 \% \text { Predominately Inattentive ADHD subtype, 3.9\% Predominantly } \\
\text { Hyperactive/Impulsive ADHD subtype, 30\% oppositional defiant disorder, } 58 \% \text { conduct disorder. }\end{array}$ \\
\hline Interventions & $\begin{array}{l}\text { Two conditions: 'Maternal Stress and Coping Group' program, modified version of the 'Coping With } \\
\text { Depression Course' (cognitive-behavioural parenting programme); wait-list control. } \\
\text { Duration of intervention: } 12 \text { weeks. } \\
\text { Duration of trial: } 3 \text { years. } \\
\text { Length of follow up: } 5 \text { months post-treatment (intervention group only). }\end{array}$ \\
\hline Outcomes & $\begin{array}{l}\text { Depressive symptoms (Beck Depression Inventory). } \\
\text { Anxiety symptoms (Beck Anxiety Inventory). } \\
\text { Stress (Perceived Stress Scale). } \\
\text { Self-esteem (Rosenberg Self-Esteem). } \\
\text { Partner satisfaction (Dyadic Adjustment Scale). }\end{array}$ \\
\hline Nuts & \\
\hline
\end{tabular}

\section{Risk of bias table}

\begin{tabular}{lll}
\hline Bias & $\begin{array}{l}\text { Authors' } \\
\text { judgement }\end{array}$ & Support for judgement \\
\hline $\begin{array}{l}\text { Random sequence generation (selection } \\
\text { bias) }\end{array}$ & Unclear Risk & $\begin{array}{l}\text { Information reported insufficient for a judgement to be } \\
\text { made. We requested clarification from the trial } \\
\text { investigators, but no further information was available at } \\
\text { the time this review was prepared. }\end{array}$ \\
\end{tabular}




\begin{tabular}{|c|c|c|}
\hline Bias & $\begin{array}{l}\text { Authors' } \\
\text { judgement }\end{array}$ & Support for judgement \\
\hline Allocation concealment (selection bias) & Unclear Risk & $\begin{array}{l}\text { Information reported insufficient for a judgement to be } \\
\text { made. We requested clarification from the trial } \\
\text { investigators, but no further information was available at } \\
\text { the time this review was prepared. }\end{array}$ \\
\hline $\begin{array}{l}\text { Blinding (performance bias and detection } \\
\text { bias) } \\
\text { Participants }\end{array}$ & High Risk & $\begin{array}{l}\text { Review authors judge that it would not be possible to } \\
\text { fully blind participants in this type of study, and found no } \\
\text { indication of any specific additional measures taken to } \\
\text { reduce the risk of bias that might result from differential } \\
\text { behaviours by participants. }\end{array}$ \\
\hline $\begin{array}{l}\text { Blinding (performance bias and detection } \\
\text { bias) } \\
\text { Personnel }\end{array}$ & Unclear Risk & $\begin{array}{l}\text { Information reported insufficient for a judgement to be } \\
\text { made. We requested clarification from the trial } \\
\text { investigators, but no further information was available at } \\
\text { the time this review was prepared. }\end{array}$ \\
\hline $\begin{array}{l}\text { Blinding (performance bias and detection } \\
\text { bias) } \\
\text { Outcome assessors }\end{array}$ & Unclear Risk & $\begin{array}{l}\text { Information reported insufficient for a judgement to be } \\
\text { made. We requested clarification from the trial } \\
\text { investigators, but no further information was available at } \\
\text { the time this review was prepared. }\end{array}$ \\
\hline Incomplete outcome data (attrition bias) & Unclear Risk & $\begin{array}{l}\text { Information reported insufficient for a judgement to be } \\
\text { made. We requested clarification from the trial } \\
\text { investigators, but no further information was available at } \\
\text { the time this review was prepared. }\end{array}$ \\
\hline Selective reporting (reporting bias) & Low Risk & $\begin{array}{l}\text { Review authors judge that the published report includes } \\
\text { all expected outcomes, including those that were pre- } \\
\text { specified. }\end{array}$ \\
\hline Other bias & Low Risk & The study appeared to be free of other sources of bias. \\
\hline
\end{tabular}




\subsubsection{Cunningham 1995}

\begin{tabular}{|c|c|}
\hline Methods & Parallel randomised controlled trial. \\
\hline Participants & $\begin{array}{l}\text { Participants: } 150 \text { volunteer parents of pre-school children with behaviour problems. } \\
\text { Sex: both mothers or fathers (no further information). } \\
\text { Age of parents: mean } 54.2 \text { years, SD } 4.4 \text { (community); mean } 52.3 \text { years, SD } 4.6 \text { (clinic); mean } 54.1 \\
\text { years, SD } 4.5 \text { (control). } \\
\text { Unit of allocation: individual participant. } \\
\text { Number randomised: } 150 \text { (48 group-based; } 46 \text { individual-based; } 56 \text { control). } \\
\text { Number used in analysis: } 78 \text { ( } 36 \text { group-based; } 42 \text { control). } \\
\text { Country \& setting: Canada; single-site; recruited from community and outpatient settings; delivered in } \\
\text { the community (group intervention) and in an outpatient clinic (individual intervention). } \\
\text { Inclusion criteria: parents with children rated at least } 1.5 \text { standard deviations above the mean for age } \\
\text { and sex on Home Situations Questionnaire. } \\
\text { Exclusion criteria: not stated. } \\
\text { Ethnicity: } 83 \% \text { Canadian born, } 17 \% \text { immigrants (group intervention); } 82 \% \text { Canadian born, } 18 \% \\
\text { immigrants (control). } \\
\text { Baseline characteristics: } 83 \% \text { two parents, } 50 \% \text { boys (group intervention); } 71.4 \% \text { two parents, } 46.4 \% \\
\text { boys (control). }\end{array}$ \\
\hline Interventions & $\begin{array}{l}\text { Three conditions: Cognitive-behavioural parenting programme; wait-list control; parent programme } \\
\text { delivered on a individual basis. } \\
\text { Duration of intervention: } 11 \text { to } 12 \text { weeks. } \\
\text { Length of follow-up: 6-months. }\end{array}$ \\
\hline Outcomes & $\begin{array}{l}\text { Depressive symptoms (Beck Depression Inventory). } \\
\text { Confidence (Parenting Sense of Competence Scale). }\end{array}$ \\
\hline Notes & \\
\hline
\end{tabular}

\section{Risk of bias table}

\begin{tabular}{|c|c|c|}
\hline Bias & $\begin{array}{l}\text { Authors' } \\
\text { judgement }\end{array}$ & Support for judgement \\
\hline $\begin{array}{l}\text { Random sequence generation (selection } \\
\text { bias) }\end{array}$ & Low Risk & $\begin{array}{l}\text { Trial investigators report that "those returning } \\
\text { questionnaires above } 90^{\text {th }} \text { percentile were block } \\
\text { randomly assigned to one of three treatment conditions" } \\
\text { (Abstract). Sequence generation process was not } \\
\text { described, but information from trial investigator (email } \\
\text { from C.Cunningham to NH on } 22 \text { Oct 2010) indicates } \\
\text { that a random numbers table was used. }\end{array}$ \\
\hline Allocation concealment (selection bias) & Low Risk & $\begin{array}{l}\text { Trial investigators report that "sealed questionnaire } \\
\text { were returned to the school and forwarded unopened to } \\
\text { the research team" (page 1143). Review authors } \\
\text { judged that allocation was probably adequately }\end{array}$ \\
\hline
\end{tabular}




\begin{tabular}{|c|c|c|}
\hline Bias & $\begin{array}{l}\text { Authors' } \\
\text { judgement }\end{array}$ & Support for judgement \\
\hline & & concealed. \\
\hline $\begin{array}{l}\text { Blinding (performance bias and detection } \\
\text { bias) } \\
\text { Participants }\end{array}$ & High Risk & $\begin{array}{l}\text { Review authors judge that it would not be possible to } \\
\text { fully blind participants in this type of study, and found no } \\
\text { indication of any specific additional measures taken to } \\
\text { reduce the risk of bias that might result from differential } \\
\text { behaviours by participants. }\end{array}$ \\
\hline $\begin{array}{l}\text { Blinding (performance bias and detection } \\
\text { bias) } \\
\text { Personnel }\end{array}$ & High Risk & $\begin{array}{l}\text { Design of study means personnel would be aware } \\
\text { which groups had been assigned to an intervention } \\
\text { condition. }\end{array}$ \\
\hline $\begin{array}{l}\text { Blinding (performance bias and detection } \\
\text { bias) } \\
\text { Outcome assessors }\end{array}$ & Low Risk & $\begin{array}{l}\text { Trial investigators report "data were collected during } \\
\text { home visits by research assistants who were } \\
\text { uninformed of the family's condition" (page 1145). } \\
\text { Review authors judge that outcome assessors were } \\
\text { blind to allocation status of participants. }\end{array}$ \\
\hline Incomplete outcome data (attrition bias) & Low Risk & $\begin{array}{l}\text { Trial investigators report "of the } 150 \text { participants } \\
\text { beginning the trial, } 36 \text { (24\%) failed to complete the } 6 \\
\text { month follow-up. The number of dropouts in the } \\
\text { respective conditions did not differ significantly" (page } \\
\text { 1148). Missing outcome data balanced in numbers } \\
\text { across intervention groups. Information from trial } \\
\text { investigator (email from C.Cunningham to NH on } 22 \text { Oct } \\
\text { 2010) indicates that the missing data were balanced } \\
\text { between conditions and reflected dropout from the } \\
\text { study. }\end{array}$ \\
\hline Selective reporting (reporting bias) & Low Risk & $\begin{array}{l}\text { Review authors judge that the published report includes } \\
\text { all expected outcomes, including those that were pre- } \\
\text { specified. }\end{array}$ \\
\hline Other bias & Low Risk & The study appears to be free of other sources of bias. \\
\hline
\end{tabular}

\subsubsection{DeGarmo 2004}

\begin{tabular}{ll}
\hline Methods & Parallel randomised controlled trial. \\
\hline Participants & Participants: separated single mothers and their sons aged 6 to 10 years recruited in the community \\
\cline { 2 - 2 } & $\begin{array}{l}\text { and in divorce court record departments. } \\
\text { Sex: all mothers. }\end{array}$ \\
& $\begin{array}{l}\text { Age of parents: mean } 34.8 \text { years (SD 5.4; range 21.4 to 49.6). } \\
\text { Unit of allocation: mother/child dyads. }\end{array}$ \\
& Number randomised: 238 (153 intervention; 85 control). \\
\hline
\end{tabular}


Number used in analysis: 216 (137 intervention; 79 control) at short-term follow-up; 179 (116 intervention; 63 control) at long-term follow-up.

Country \& setting: USA; single-site; recruited from community settings: intervention delivered in the community.

Inclusion criteria: single mothers; separated from partner within the prior 3 to 24 months; residing with a biological son of school grade between 1 and 6 inclusive; not cohabiting with a new partner.

Exclusion criteria: not stated.

Ethnicity: 86\% white, 1\% African American, 2\% Latino; 2\% Native American, 9\% other.

Baseline characteristics: mean separation time 9.2 months; mean 2.1 children per family; $76 \%$ receiving public assistance; education: $76 \%$ mothers had some academic or vocational training beyond high school; $14 \%$ mothers had completed college degree or higher; $4 \%$ mothers had not completed high school; $49 \%$ mothers clinically depressed as assessed by cut-off score of 16 on CES-

D.

Interventions Two conditions: Parent management training (behavioural parenting programme); no-treatment control.

Duration of intervention: 14 weeks.

Duration of trial: 30 months.

Length of follow up: 12 months, 18 months, and 30 months.

Outcomes

Depressive symptoms (Center for Epidemiologic Studies Depression Scale).

\section{Risk of bias table}

\begin{tabular}{lll}
\hline Bias & $\begin{array}{l}\text { Authors' } \\
\text { judgement }\end{array}$ & Support for judgement \\
\hline $\begin{array}{ll}\text { Random sequence generation (selection } \\
\text { bias) }\end{array}$ & Low Risk & $\begin{array}{l}\text { Information reported insufficient for a judgement to be } \\
\text { made, but information from trial investigator (email from }\end{array}$ \\
& & $\begin{array}{l}\text { D.DeGarmo to CB on 14 Jul 2010) states "we used } \\
\text { block randomisation and fixed allocation 3:2, families } \\
\text { were first recruited in blocked cohorts; a data manager } \\
\end{array}$ \\
& $\begin{array}{l}\text { used a random number generator and probabilities } \\
\text { adjusted for fixed allocation for that cohort". }\end{array}$ \\
\hline
\end{tabular}

Allocation concealment (selection bias) Unclear Risk Information reported insufficient for a judgement to be made. We requested clarification from the trial investigators, but no further information was available at the time this review was prepared.

$\begin{array}{ll}\begin{array}{l}\text { Blinding (performance bias and detection } \\ \text { bias) }\end{array} & \text { High Risk } \\ \text { Participants } & \begin{array}{l}\text { Review authors judge that it would not be possible to } \\ \text { fully blind participants in this type of study, and found no } \\ \text { indication of any specific additional measures taken to }\end{array} \\ & \text { reduce the risk of bias that might result from differential }\end{array}$




\begin{tabular}{|c|c|c|}
\hline Bias & $\begin{array}{l}\text { Authors' } \\
\text { judgement }\end{array}$ & Support for judgement \\
\hline & & behaviours by participants. \\
\hline $\begin{array}{l}\text { Blinding (performance bias and detection } \\
\text { bias) }\end{array}$ & Low Risk & $\begin{array}{l}\text { Information reported insufficient for a judgement to be } \\
\text { made, but information from trial investigator (email from }\end{array}$ \\
\hline Personnel & & $\begin{array}{l}\text { DeGarmo to CB on) states "all assessors, interviewers, } \\
\text { and coders were blind to participants assigned group } \\
\text { status. Coders and interviewers were mismatched } \\
\text { across waves so they were not exposed to the same } \\
\text { families wherever possible". }\end{array}$ \\
\hline $\begin{array}{l}\text { Blinding (performance bias and detection } \\
\text { bias) }\end{array}$ & Low Risk & $\begin{array}{l}\text { Information reported insufficient for a judgement to be } \\
\text { made, but information from trial investigator (email from }\end{array}$ \\
\hline Outcome assessors & & $\begin{array}{l}\text { D.DeGarmo to CB on } 14 \text { Jul 2010) states "all } \\
\text { assessors, interviewers, and coders were blind to } \\
\text { participants assigned group status. Coders and } \\
\text { interviewers were mismatched across waves so they } \\
\text { were not exposed to the same families wherever } \\
\text { possible". }\end{array}$ \\
\hline Incomplete outcome data (attrition bias) & Unclear Risk & $\begin{array}{l}\text { Information reported insufficient for a judgement to be } \\
\text { made. We requested clarification from the trial } \\
\text { investigators, but no further information was available at } \\
\text { the time this review was prepared. }\end{array}$ \\
\hline Selective reporting (reporting bias) & Low Risk & $\begin{array}{l}\text { Review authors judge that the published report includes } \\
\text { all expected outcomes, including those that were pre- } \\
\text { specified. }\end{array}$ \\
\hline Other bias & Low Risk & The study appears to be free of other sources of bias. \\
\hline
\end{tabular}

\subsubsection{Fanning 2007}

\begin{tabular}{|c|c|}
\hline Methods & Parallel randomised controlled trial. \\
\hline \multirow[t]{8}{*}{ Participants } & Participants: families recruited across 15-month period from four local Head Start preschools. \\
\hline & Sex: both mothers and fathers (no further information). \\
\hline & Age of parents: mean 31 years intervention; mean 27 years control. \\
\hline & Unit of allocation: individual family. \\
\hline & Number randomised: 40 families (18 intervention; 22 control). \\
\hline & Number used in analysis: 19 families (10 intervention; 9 control). \\
\hline & $\begin{array}{l}\text { Country \& setting: USA; multi-site }(n=4) \text {; recruited from community settings: intervention delivered in } \\
\text { the community. }\end{array}$ \\
\hline & $\begin{array}{l}\text { Inclusion criteria: families with children attending local Head Start preschools; aged } 3 \text { to } 5 \text { years; from } \\
\text { economically disadvantaged backgrounds; monolingual; right-handed. }\end{array}$ \\
\hline
\end{tabular}


Exclusion criteria: taking psychopharmacological medication for ADD, ADHD, seizures or depression. Ethnicity: not stated.

Baseline characteristics: education: mean 13.29 years (intervention group) and 12.93 years (control group); maternal education: mean 13.21 years (intervention); mean 12.80 years (control).

\begin{tabular}{|c|c|}
\hline Interventions & $\begin{array}{l}\text { Two conditions: 'Success in Parenting Preschoolers' (SIP2); wait-list control. } \\
\text { Duration of intervention: } 8 \text { weeks. } \\
\text { Length of follow-up: no follow-up. }\end{array}$ \\
\hline Outcomes & Stress (Ability and Confidence Rating Questionnaire). \\
\hline Notes & \\
\hline
\end{tabular}

\section{Risk of bias table}

\begin{tabular}{lll}
\hline Bias & $\begin{array}{l}\text { Authors' } \\
\text { judgement }\end{array}$ & Support for judgement \\
\hline $\begin{array}{l}\text { Random sequence generation (selection } \\
\text { bias) }\end{array}$ & Unclear Risk & $\begin{array}{l}\text { Information reported insufficient for a judgement to be } \\
\text { made. We requested clarification from the trial } \\
\text { investigators, but no further information was available at } \\
\text { the time this review was prepared. }\end{array}$ \\
\hline Allocation concealment (selection bias) & Unclear Risk & $\begin{array}{l}\text { Information reported insufficient for a judgement to be } \\
\text { made. We requested clarification from the trial } \\
\text { investigators, but no further information was available at } \\
\text { the time this review was prepared. }\end{array}$ \\
\hline
\end{tabular}

Blinding (performance bias and detection High Risk bias)

Participants
Review authors judge that it would not be possible to fully blind participants in this type of study, and found no indication of any specific additional measures taken to reduce the risk of bias that might result from differential behaviours by participants.

Trial investigators report that trial personnel were blind to allocation status of participants (page 69).

Personnel

Blinding (performance bias and detection Low Risk bias)

Outcome assessors

Incomplete outcome data (attrition bias) Unclear Risk Data for $4 / 18(22.2 \%)$ were missing from the intervention condition (1 unwilling to attend in evenings; 1 needing to work in evenings, 1 evicted and moved to new area; 1 reason unknown), and for 8/22 (36.3\%) from the control condition. Overall attrition was $19 \%$ at post-intervention. Review authors considered the numbers of missing data not closely balanced between 


\begin{tabular}{lll}
\hline Bias & $\begin{array}{l}\text { Authors' } \\
\text { judgement }\end{array}$ & Support for judgement \\
\hline & & $\begin{array}{l}\text { conditions. Since reasons for attrition not provided for } \\
\text { control group, it is not possible to judge whether the } \\
\text { reasons for the missing data differ substantially across } \\
\text { the groups. We requested clarification from the trial } \\
\text { investigators, but no further information was available at } \\
\text { the time this review was prepared. }\end{array}$ \\
& Low Risk & $\begin{array}{l}\text { Review authors judge that the published report includes } \\
\text { all expected outcomes, including those that were pre- } \\
\text { Selective reporting (reporting bias) }\end{array}$ \\
& Low Risk & The study appears to be free of other sources of bias. \\
\hline Other bias &
\end{tabular}

\subsubsection{Fantuzzo 2007}

\begin{tabular}{|c|c|}
\hline Methods & Parallel randomised controlled trial. \\
\hline Participants & $\begin{array}{l}\text { Participants: parents of the Head Start children recruited from } 10 \text { central-city Head Start centres. } \\
\text { Sex: } 111 \text { mothers; } 5 \text { fathers. } \\
\text { Age of parents: mean } 30.8 \text { years. } \\
\text { Unit of allocation: individual participant. } \\
\text { Number randomised: } 116 \text { ( } 61 \text { treatment; } 55 \text { control). } \\
\text { Number used in analysis: } 76 \text { ( } 39 \text { treatment; } 37 \text { control). } \\
\text { Country \& setting: USA; multi-site ( } n=10) ; \text { recruited from community settings; intervention delivered in } \\
\text { the community. } \\
\text { Inclusion criteria: socially isolated parents, who were given a rating of 'low' engagement in term of } \\
\text { their adult social interaction in Head Start activities by the teacher of their child. } \\
\text { Exclusion criteria: not stated. } \\
\text { Ethnicity: } 100 \% \text { African-American. } \\
\text { Baseline characteristics: } 84 \% \text { were the Head Start child's mother, } 13 \% \text { grandmothers or aunts, } 3 \% \\
\text { fathers; } 70 \% \text { families headed by single mothers; average number of children per household } 2.78 ; 40 \\
\text { parents (34.4\%) had a history of maltreatment involving their Head Start child. }\end{array}$ \\
\hline Interventions & $\begin{array}{l}\text { Two conditions: Community outreach through parent empowerment (COPE); treatment as usual } \\
\text { control. } \\
\text { Duration of intervention: } 10 \text { sessions (duration not stated). } \\
\text { Length of follow up: none. }\end{array}$ \\
\hline Outcomes & Stress (Uplifts and Hassles Scales). \\
\hline Notes & Parallel randomised controlled trial. \\
\hline
\end{tabular}


Risk of bias table

\begin{tabular}{|c|c|c|}
\hline Bias & $\begin{array}{l}\text { Authors' } \\
\text { judgement }\end{array}$ & Support for judgement \\
\hline $\begin{array}{l}\text { Random sequence generation (selection } \\
\text { bias) }\end{array}$ & Unclear Risk & $\begin{array}{l}\text { Information reported insufficient for a judgement to be } \\
\text { made. We requested clarification from the trial } \\
\text { investigators, but no further information was available at } \\
\text { the time this review was prepared. }\end{array}$ \\
\hline Allocation concealment (selection bias) & Unclear Risk & $\begin{array}{l}\text { Information reported insufficient for a judgement to be } \\
\text { made. We requested clarification from the trial } \\
\text { investigators, but no further information was available at } \\
\text { the time this review was prepared. }\end{array}$ \\
\hline $\begin{array}{l}\text { Blinding (performance bias and detection } \\
\text { bias) } \\
\text { Participants }\end{array}$ & High Risk & $\begin{array}{l}\text { Review authors judge that it would not be possible to } \\
\text { fully blind participants in this type of study, and found no } \\
\text { indication of any specific additional measures taken to } \\
\text { reduce the risk of bias that might result from differential } \\
\text { behaviours by participants. }\end{array}$ \\
\hline $\begin{array}{l}\text { Blinding (performance bias and detection } \\
\text { bias) } \\
\text { Personnel }\end{array}$ & Unclear Risk & $\begin{array}{l}\text { Information reported insufficient for a judgement to be } \\
\text { made. We requested clarification from the trial } \\
\text { investigators, but no further information was available at } \\
\text { the time this review was prepared. }\end{array}$ \\
\hline $\begin{array}{l}\text { Blinding (performance bias and detection } \\
\text { bias) } \\
\text { Outcome assessors }\end{array}$ & Low Risk & $\begin{array}{l}\text { Trial investigators report that outcome assessors were } \\
\text { blind to allocation status of participants (page } 84, \mathrm{col} 2 \text { ). }\end{array}$ \\
\hline Incomplete outcome data (attrition bias) & Low Risk & There were no missing data. \\
\hline Selective reporting (reporting bias) & Low Risk & $\begin{array}{l}\text { Review authors judge that the published report includes } \\
\text { all expected outcomes, including those that were pre- } \\
\text { specified. }\end{array}$ \\
\hline Other bias & Low Risk & The study appears to be free of other forms of bias. \\
\hline
\end{tabular}




\subsubsection{Farrar 2005}

\begin{tabular}{|c|c|}
\hline Methods & Parallel randomised controlled trial. \\
\hline Participants & 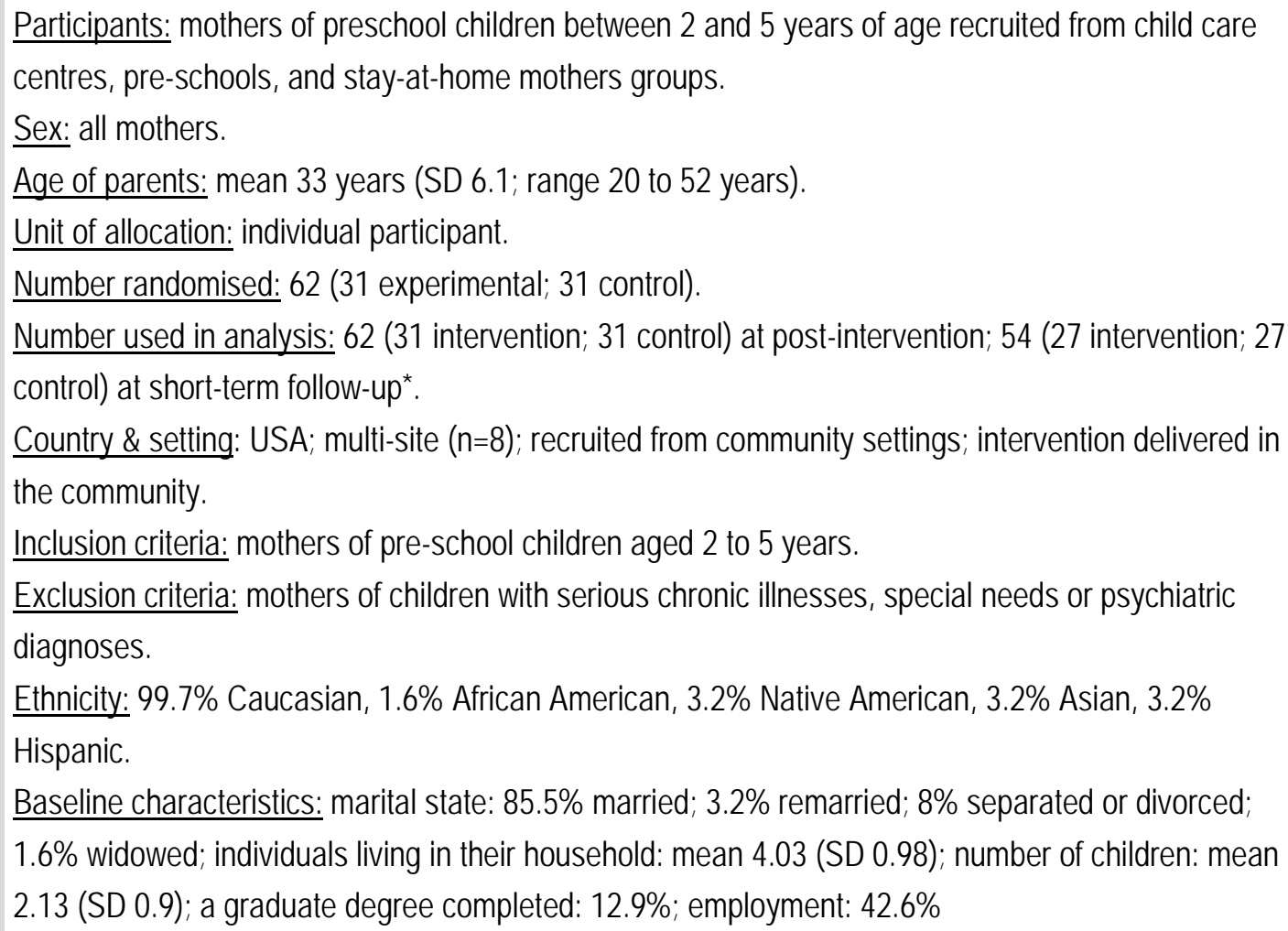 \\
\hline Interventions & $\begin{array}{l}\text { Two conditions: Cognitive parenting programme; attention-placebo control. } \\
\text { Duration of intervention: } 30 \text { minutes. } \\
\text { Length of follow-up: } 1 \text { month. }\end{array}$ \\
\hline Outcomes & $\begin{array}{l}\text { Stress (Parental Stress Scale). } \\
\text { Confidence (Kansas Parental Satisfaction Scale). }\end{array}$ \\
\hline
\end{tabular}

\section{Risk of bias table}

\begin{tabular}{|c|c|c|}
\hline Bias & Authors' & Support for judgement \\
\hline & judgement & \\
\hline $\begin{array}{l}\text { Random sequence generation (selection } \\
\text { bias) }\end{array}$ & Low Risk & $\begin{array}{l}\text { Random sequence allocation by use of random number } \\
\text { tables (page 35). }\end{array}$ \\
\hline Allocation concealment (selection bias) & Low Risk & $\begin{array}{l}\text { Information reported insufficient to for a judgement to } \\
\text { be made, but information from trial investigator (email } \\
\text { from R Farrar to CB on } 30 \text { Aug 2010) states "the } \\
\text { allocation sequence was placed in sealed opaque } \\
\text { envelops". }\end{array}$ \\
\hline $\begin{array}{l}\text { Blinding (performance bias and detection } \\
\text { bias) } \\
\text { Participants }\end{array}$ & High Risk & $\begin{array}{l}\text { It is not possible to fully blind participants in this type of } \\
\text { study. Additional measures had been taken to reduce } \\
\text { the risk of bias that might result from differential }\end{array}$ \\
\hline
\end{tabular}




\begin{tabular}{|c|c|c|}
\hline Bias & $\begin{array}{l}\text { Authors' } \\
\text { judgement }\end{array}$ & Support for judgement \\
\hline & & $\begin{array}{l}\text { behaviours by participants: "one assessor was } \\
\text { assigned to each group (control and experimental) in } \\
\text { order to ensure that participants did not have contact } \\
\text { with members of the other group during pre-test } \\
\text { measurement, intervention and post-test measurement" } \\
\text { (page 44). }\end{array}$ \\
\hline $\begin{array}{l}\text { Blinding (performance bias and detection } \\
\text { bias) } \\
\text { Personnel }\end{array}$ & High Risk & $\begin{array}{l}\text { Information reported insufficient to for a judgement to } \\
\text { be made, but information from trial investigator (email } \\
\text { from R.Farrar to CB on } 30 \text { Aug 2010) indicates "the } \\
\text { control group interventionist was blinded to participant's } \\
\text { allocation and study hypotheses". However, the } \\
\text { experimental group interventionist was not blind to } \\
\text { allocation status of participants and study hypotheses } \\
\text { (page 35). }\end{array}$ \\
\hline $\begin{array}{l}\text { Blinding (performance bias and detection } \\
\text { bias) } \\
\text { Outcome assessors }\end{array}$ & High Risk & $\begin{array}{l}\text { Trial investigators report "one assessor was assigned to } \\
\text { each group (control and experimental) in order to } \\
\text { ensure that participants did not have contact with } \\
\text { members of the other group during pre-test } \\
\text { measurement, intervention and post-test measurement' } \\
\text { (page 44). However, the outcome assessors were not } \\
\text { blind to allocation status of participants }\end{array}$ \\
\hline Incomplete outcome data (attrition bias) & Low Risk & $\begin{array}{l}\text { Data for } 4 / 31(13 \%) \text { were missing from the intervention } \\
\text { condition, and for } 4 / 31(13 \%) \text { from the control condition. } \\
\text { Reason for missing data not given. Review authors } \\
\text { considered the numbers of missing data balanced } \\
\text { across the treatment conditions. Overall attrition was } \\
13 \% \text { at post-intervention. }\end{array}$ \\
\hline Selective reporting (reporting bias) & Low Risk & $\begin{array}{l}\text { Review authors judge that the published report includes } \\
\text { all expected outcomes, including those that were pre- } \\
\text { specified. }\end{array}$ \\
\hline Other bias & Low Risk & $\begin{array}{l}\text { Trial investigators report "various one-way ANOVAs } \\
\text { were conducted to evaluate possible differences in } \\
\text { participants who completed follow-up measures versus } \\
\text { those who failed to complete such measures. There } \\
\text { were no significant differences between completers and } \\
\text { non-completers on the following variables: age of } \\
\text { mother, age of child, number of children in the family, } \\
\text { number of hours worked per week, and socioeconomic } \\
\text { status. Further, there were no significant differences }\end{array}$ \\
\hline
\end{tabular}




\begin{tabular}{lll}
\hline Bias & $\begin{array}{l}\text { Authors' } \\
\text { judgement }\end{array}$ & Support for judgement \\
\hline & $\begin{array}{l}\text { between completers and non-completers regarding } \\
\text { scores on any dependent variables at pre-test } \\
\text { assessment" (page 48). The study appeared to be free } \\
\text { of other sources of bias. }\end{array}$ \\
\hline
\end{tabular}

\subsubsection{Feliciana 2005}

\begin{tabular}{|c|c|}
\hline Methods & Parallel randomised controlled trial. \\
\hline Participants & $\begin{array}{l}\text { Participants: low-to-middle income Africa American mothers who have at least one child between } 5-12 \\
\text { years old were recruited through letters and flyers at two sites. } \\
\text { Sex: all mothers. } \\
\text { Age of parents: mean } 27.8 \text { years (SD } 2.42 ; \text { range } 23 \text { to } 33 \text { ). } \\
\text { Unit of allocation: individual participant. } \\
\text { Number randomised: } 60 \text { (30 intervention; } 30 \text { control). } \\
\text { Number used in analysis: } 60 \text { (30 intervention; } 30 \text { control). } \\
\text { Country \& setting: USA; single-site; recruited from community settings; intervention delivered in the } \\
\text { community. } \\
\text { Inclusion criteria: African-American mothers; low-to-middle income; at least one child aged } 5 \text { to } 12 ; \\
\text { interest in participating in a parenting skills training program. } \\
\text { Exclusion criteria: not stated. } \\
\text { Ethnicity: all African-American. } \\
\text { Baseline characteristics: } \\
\text { Intervention group: education: } 12 \% \text { at least } 2 \text { years post secondary education; } 9 \% \text { completed at least } \\
4 \text { years of college; marital status: } 63 \% \text { single; } 30 \% \text { married; } 7 \% \text { divorced; number of children: } 27 \% \\
\text { only one child; } 67 \% \text { had } 2 \text { or } 3 \text { children; } 7 \% 4 \text { or more children. } \\
\text { Control group: education: } 15 \% \text { at least } 2 \text { years post secondary education; } 8 \% \text { completed at least } 4 \\
\text { years of college; marital status: } 70 \% \text { single; } 27 \% \text { married; } 3 \% \text { divorced; number of children: } 37 \% \text { had } \\
\text { only one child; } 60 \% \text { had } 2 \text { or } 3 \text { children; } 3 \% 4 \text { or more children. }\end{array}$ \\
\hline Interventions & $\begin{array}{l}\text { Two conditions: Active Parenting Programme; wait-list control. } \\
\text { Duration of intervention: } 5 \text { weeks. } \\
\text { Length of follow-up: none. }\end{array}$ \\
\hline Outcomes & $\begin{array}{l}\text { Depressive symptoms (Parenting Stress Index). } \\
\text { Stress (Parenting Stress Index). } \\
\text { Confidence (Parenting Sense of Competence Scale). }\end{array}$ \\
\hline & \\
\hline
\end{tabular}

\section{Risk of bias table}

\begin{tabular}{lll} 
Bias & $\begin{array}{l}\text { Authors' } \\
\text { judgement }\end{array}$ & Support for judgement \\
\hline
\end{tabular}




\begin{tabular}{|c|c|c|}
\hline Bias & $\begin{array}{l}\text { Authors' } \\
\text { judgement }\end{array}$ & Support for judgement \\
\hline $\begin{array}{l}\text { Random sequence generation (selection } \\
\text { bias) }\end{array}$ & Unclear Risk & $\begin{array}{l}\text { Trial investigators report "mothers were selected on } \\
\text { first-come, first-served basis and randomly assigned to } \\
\text { either the control group or the treatment group" (page } \\
\text { 40). Insufficient information to make judgment. We } \\
\text { requested clarification from the trial investigators, but no } \\
\text { further information was available at the time this review } \\
\text { was prepared. }\end{array}$ \\
\hline Allocation concealment (selection bias) & Unclear Risk & $\begin{array}{l}\text { Information reported insufficient for a judgement to be } \\
\text { made. We requested clarification from the trial } \\
\text { investigators, but no further information was available at } \\
\text { the time this review was prepared. }\end{array}$ \\
\hline $\begin{array}{l}\text { Blinding (performance bias and detection } \\
\text { bias) } \\
\text { Participants }\end{array}$ & High Risk & $\begin{array}{l}\text { Review authors judge that it would not be possible to } \\
\text { fully blind participants in this type of study, and found no } \\
\text { indication of any specific additional measures taken to } \\
\text { reduce the risk of bias that might result from differential } \\
\text { behaviours by participants. }\end{array}$ \\
\hline $\begin{array}{l}\text { Blinding (performance bias and detection } \\
\text { bias) } \\
\text { Personnel }\end{array}$ & Unclear Risk & $\begin{array}{l}\text { Information reported insufficient for a judgement to be } \\
\text { made. We requested clarification from the trial } \\
\text { investigators, but no further information was available at } \\
\text { the time this review was prepared. }\end{array}$ \\
\hline $\begin{array}{l}\text { Blinding (performance bias and detection } \\
\text { bias) } \\
\text { Outcome assessors }\end{array}$ & Unclear Risk & $\begin{array}{l}\text { Information reported insufficient for a judgement to be } \\
\text { made. We requested clarification from the trial } \\
\text { investigators, but no further information was available at } \\
\text { the time this review was prepared. }\end{array}$ \\
\hline Incomplete outcome data (attrition bias) & Low Risk & There were no missing outcome data. \\
\hline Selective reporting (reporting bias) & Low Risk & $\begin{array}{l}\text { Review authors judge that the published report includes } \\
\text { all expected outcomes, including those that were pre- } \\
\text { specified. }\end{array}$ \\
\hline Other bias & Low Risk & The study appears to be free of other sources of bias. \\
\hline
\end{tabular}




\subsubsection{Gallart 2005}

\begin{tabular}{|c|c|}
\hline Methods & Parallel randomised controlled trial. \\
\hline Participants & $\begin{array}{l}\text { Participants: parents of children between the ages of } 2 \text { and } 8 \text { years, who were experiencing difficulties } \\
\text { with their children's disruptive behaviours. They were recruited following advertising of the Group } \\
\text { Triple P program in community through newspapers, pre-schools, schools, playgroups and health } \\
\text { professionals. } \\
\text { Sex: } 46 \text { mothers; } 3 \text { fathers. } \\
\text { Age of parents: not stated. } \\
\text { Unit of allocation: individual participant. } \\
\text { Number randomised: } 49 \text { (16 full intervention; } 17 \text { modified intervention; } 16 \text { control). } \\
\text { Number used in analysis: } 32 \text { (16 full intervention; } 16 \text { control) } \\
\text { Country \& setting: Australia; single-site; recruited from community settings; intervention delivered in } \\
\text { Ine community. } \\
\text { disclusion criteria: parenting a child between } 2 \text { and } 8 \text { years old; experiencing difficulties with child's } \\
\text { Exclusion criteria: not stated. } \\
\text { Ethnicity: English-speaking background (56\%); others from various backgrounds including Italian, } \\
\text { Maltese, Serbo-Croatian, Armenian, Vietnamese and Uruguayan; children were aged } 3 \text { to } 8 \text { years } \\
\text { (mean 5.4, SD 1.5 years). } \\
\text { Baseline characteristics: } 100 \% \text { scored above the clinical cut-off on at least one of the measures at the } \\
\text { commencement of the program; three quarters had left school prior to year } 12 .\end{array}$ \\
\hline Interventions & $\begin{array}{l}\text { Three conditions: Group Triple-P program; modified Group Triple-P program (no phone contact); wait- } \\
\text { list control. } \\
\text { Duration of intervention: } 8 \text { weeks full intervention; } 4 \text { weeks modified intervention (although endpoint } \\
\text { measures at } 8 \text { weeks). } \\
\text { Duration of trial: } 8 \text { weeks. } \\
\text { Length of follow up: none. }\end{array}$ \\
\hline Outcomes & $\begin{array}{l}\text { Depressive symptoms (Depression Anxiety Stress Scales). } \\
\text { Anxiety symptoms (Depression Anxiety Stress Scales). } \\
\text { Stress (Depression Anxiety Stress Scales). }\end{array}$ \\
\hline otes & \\
\hline
\end{tabular}

\section{Risk of bias table}

\begin{tabular}{|c|c|c|}
\hline Bias & $\begin{array}{l}\text { Authors' } \\
\text { judgement }\end{array}$ & Support for judgement \\
\hline $\begin{array}{l}\text { Random sequence generation (selection } \\
\text { bias) }\end{array}$ & Low Risk & $\begin{array}{l}\text { Trial investigators report "on registering, participants } \\
\text { were randomly assigned to one of three conditions' } \\
\text { (page } 75 \text { ). Insufficient information to make judgment, } \\
\text { but information from trial investigator (email from S } \\
\text { Matthey to CB on } 07 \text { Nov 2010) states "randomisation } \\
\text { was by out of the hat method". }\end{array}$ \\
\hline
\end{tabular}




\begin{tabular}{|c|c|c|}
\hline Bias & $\begin{array}{l}\text { Authors' } \\
\text { judgement }\end{array}$ & Support for judgement \\
\hline Allocation concealment (selection bias) & High Risk & $\begin{array}{l}\text { The trial investigators confirmed that allocation was not } \\
\text { concealed. }\end{array}$ \\
\hline $\begin{array}{l}\text { Blinding (performance bias and detection } \\
\text { bias) } \\
\text { Participants }\end{array}$ & High Risk & $\begin{array}{l}\text { Participants were not fully blinded to allocation. Trial } \\
\text { investigators report "participants were kept blind to the } \\
\text { fact that there were two different formats of the } \\
\text { program. Those in the ' } 4 \text { only' condition were informed } \\
\text { that the program had been slightly modified and did not } \\
\text { include the telephone sessions described in their } \\
\text { workbook. Those in the control condition were sent the } \\
\text { initial assessment package, and when this was returned } \\
\text { were informed that the program was full, and that they } \\
\text { would be allocated to the next available program (this } \\
\text { was offered them when they were mailed their post- } \\
\text { assessments)" (page } 75) \text {. }\end{array}$ \\
\hline $\begin{array}{l}\text { Blinding (performance bias and detection } \\
\text { bias) } \\
\text { Personnel }\end{array}$ & High Risk & $\begin{array}{l}\text { Information reported insufficient for a judgement to be } \\
\text { made, but information from trial investigator (email from } \\
\text { S Matthey to CB on } 07 \text { Nov 2010) states "personnel not } \\
\text { blinded". }\end{array}$ \\
\hline $\begin{array}{l}\text { Blinding (performance bias and detection } \\
\text { bias) } \\
\text { Outcome assessors }\end{array}$ & High Risk & $\begin{array}{l}\text { Information reported insufficient for a judgement to be } \\
\text { made, but information from trial investigator (email from } \\
\text { S Matthey to CB on } 07 \text { Nov 2010) states "personnel not } \\
\text { blinded". }\end{array}$ \\
\hline Incomplete outcome data (attrition bias) & Unclear Risk & $\begin{array}{l}\text { Overall, data from } 5 / 54 \text { ( } 9 \% \text { ) of those randomised were } \\
\text { missing and results given only for the } 49 \text { with pre-post } \\
\text { data. Breakdown of missing data by allocated group not } \\
\text { given. Reasons for missing data not given. Insufficient } \\
\text { information to judge whether missing data balances } \\
\text { across treatment conditions or whether the reasons for } \\
\text { the missing data differ substantially across the groups. } \\
\text { We requested clarification from the trial investigators, } \\
\text { but no further information was available (email from S } \\
\text { Matthey to CB on } 07 \text { Nov 2010). }\end{array}$ \\
\hline Selective reporting (reporting bias) & Low Risk & $\begin{array}{l}\text { Review authors judge that the published report includes } \\
\text { all expected outcomes, including those that were pre- } \\
\text { specified. }\end{array}$ \\
\hline Other bias & Low Risk & The study appears to be free of other sources of bias. \\
\hline
\end{tabular}




\subsubsection{Gammon 1991}

\begin{tabular}{|c|c|}
\hline Methods & Parallel randomised controlled trial. \\
\hline Participants & $\begin{array}{l}\text { Participants: volunteers or professionally referred parents of children with a disability. } \\
\text { Sex: all mothers. } \\
\text { Age of parents: mean } 38.8 \text { years, intervention; mean } 37.8 \text { years, control. } \\
\text { Unit of allocation: individual participant. } \\
\text { Number randomised: } 42 \text { ( } 24 \text { intervention; } 18 \text { control). } \\
\text { Number used in analysis: number available for analysis not stated. } \\
\text { Country \& setting: USA; single-site; recruited from community settings; intervention delivered in the } \\
\text { community. } \\
\text { Inclusion criteria: the parents must have known about their child's disability for at least } 6 \text { months and } \\
\text { have verbally indicated that they were currently having difficulties related to child's behaviour; the } \\
\text { parents were available to participate for the } 10 \text {-week duration of the study. } \\
\text { Exclusion criteria: not stated. } \\
\text { Ethnicity: not stated. } \\
\text { Baseline characteristics: not stated. }\end{array}$ \\
\hline Interventions & $\begin{array}{l}\text { Two condition: Cognitive-behavioural parenting programme; no-treatment control. } \\
\text { Duration of intervention: } 10 \text { weeks. } \\
\text { Duration of trial: } 10 \text { weeks. } \\
\text { Length of follow-up: none. }\end{array}$ \\
\hline Outcomes & $\begin{array}{l}\text { Stress (Profile of Mood State)*. } \\
\text { Stress (Questionnaire on Resources and Stress)*. }\end{array}$ \\
\hline Notes & $\begin{array}{l}\text { *Insufficient data to calculate effect sizes. Clarification was requested from the trial investigators but } \\
\text { no further information was available at the time this review was prepared. }\end{array}$ \\
\hline
\end{tabular}

\section{Risk of bias table}

\begin{tabular}{|c|c|c|}
\hline Bias & $\begin{array}{l}\text { Authors' } \\
\text { judgement }\end{array}$ & Support for judgement \\
\hline $\begin{array}{l}\text { Random sequence generation (selection } \\
\text { bias) }\end{array}$ & Unclear Risk & $\begin{array}{l}\text { Information reported insufficient for a judgement to be } \\
\text { made. We requested clarification from the trial } \\
\text { investigators, but no further information was available at } \\
\text { the time this review was prepared. }\end{array}$ \\
\hline Allocation concealment (selection bias) & Unclear Risk & $\begin{array}{l}\text { Information reported insufficient for a judgement to be } \\
\text { made. We requested clarification from the trial } \\
\text { investigators, but no further information was available at } \\
\text { the time this review was prepared. }\end{array}$ \\
\hline $\begin{array}{l}\text { Blinding (performance bias and detection } \\
\text { bias) } \\
\text { Participants }\end{array}$ & High Risk & $\begin{array}{l}\text { Review authors judge that it would not be possible to } \\
\text { fully blind participants in this type of study, and found no } \\
\text { indication of any specific additional measures taken to } \\
\text { reduce the risk of bias that might result from differential }\end{array}$ \\
\hline
\end{tabular}




\begin{tabular}{|c|c|c|}
\hline Bias & $\begin{array}{l}\text { Authors' } \\
\text { judgement }\end{array}$ & Support for judgement \\
\hline & & behaviours by participants. \\
\hline $\begin{array}{l}\text { Blinding (performance bias and detection } \\
\text { bias) }\end{array}$ & Unclear Risk & $\begin{array}{l}\text { Information reported insufficient for a judgement to be } \\
\text { made. We requested clarification from the trial }\end{array}$ \\
\hline Personnel & & $\begin{array}{l}\text { investigators, but no further information was available at } \\
\text { the time this review was prepared. }\end{array}$ \\
\hline $\begin{array}{l}\text { Blinding (performance bias and detection } \\
\text { bias) }\end{array}$ & Unclear Risk & $\begin{array}{l}\text { Information reported insufficient for a judgement to be } \\
\text { made. We requested clarification from the trial }\end{array}$ \\
\hline Outcome assessors & & $\begin{array}{l}\text { investigators, but no further information was available at } \\
\text { the time this review was prepared. }\end{array}$ \\
\hline Incomplete outcome data (attrition bias) & Unclear Risk & $\begin{array}{l}\text { Trial investigators do not report the numbers of } \\
\text { participants completing the study. We requested } \\
\text { clarification from the trial investigators, but no further } \\
\text { information was available at the time this review was } \\
\text { prepared. }\end{array}$ \\
\hline Selective reporting (reporting bias) & Low Risk & $\begin{array}{l}\text { Review authors judge that the published report includes } \\
\text { all expected outcomes, including those that were pre- } \\
\text { specified. }\end{array}$ \\
\hline Other bias & Low Risk & $\begin{array}{l}\text { The review appeared free of other forms of bias } \\
\text { although, as the trial investigators note, "the absence of } \\
\text { a placebo control group suggest that the role of social } \\
\text { desirability effects cannot be excluded in accounting for } \\
\text { the results" (page 255). }\end{array}$ \\
\hline
\end{tabular}




\subsubsection{Gardner 2006}

\begin{tabular}{|c|c|}
\hline Methods & Parallel randomised control trial. \\
\hline Participants & 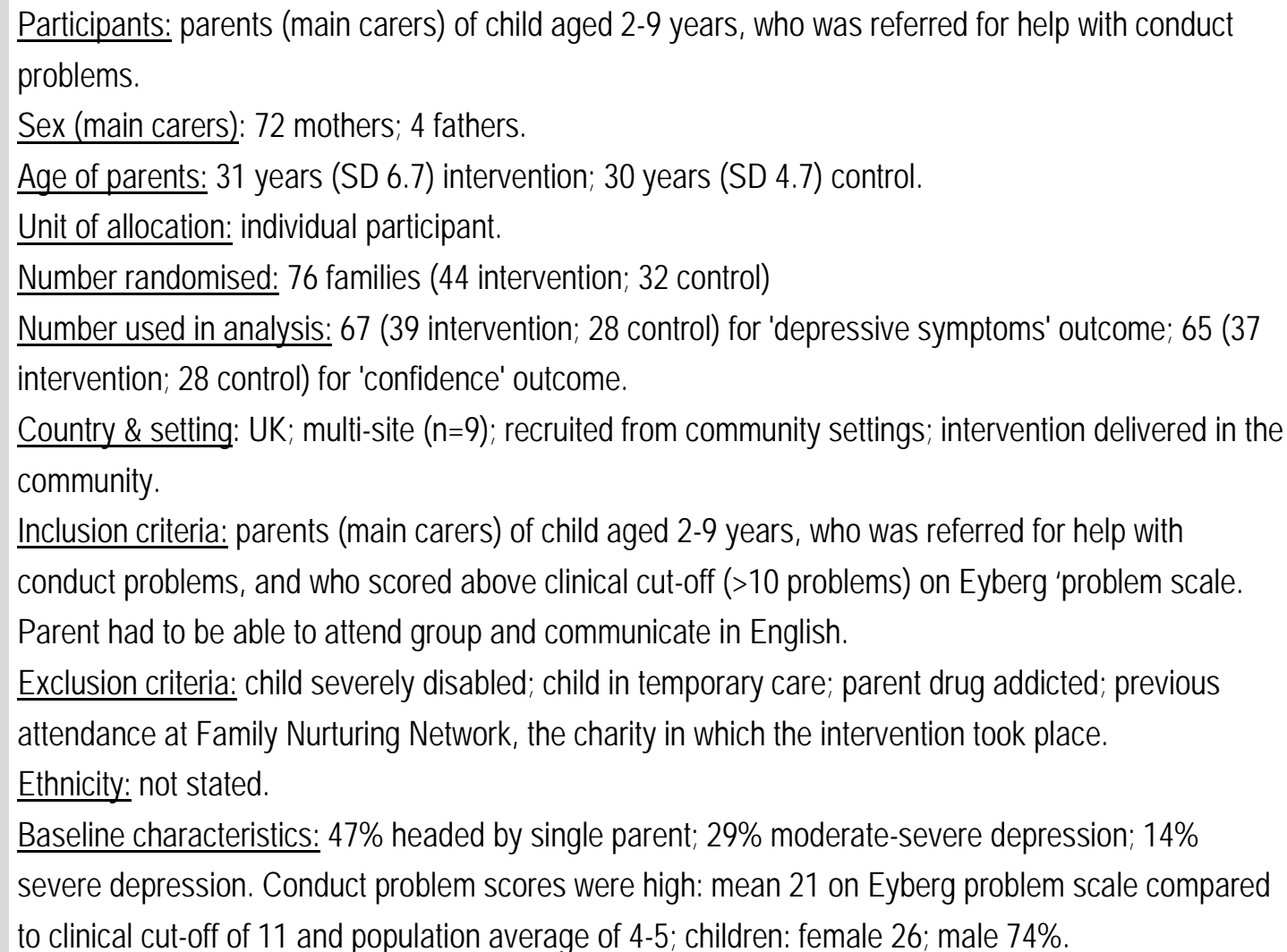 \\
\hline Interventions & $\begin{array}{l}\text { Two conditions: Webster-Stratton 'Incredible Years'; wait-list control. } \\
\text { Duration of intervention: } 14 \text { weeks. } \\
\text { Length of follow up: } 18 \text { months post-recruitment }\end{array}$ \\
\hline Outcomes & $\begin{array}{l}\text { Depressive symptoms (Back Depression Inventory). } \\
\text { Confidence (Parenting Sense of Competence Scale). }\end{array}$ \\
\hline Notes & \\
\hline
\end{tabular}

\section{Risk of bias table}

\begin{tabular}{lll}
\hline Bias & $\begin{array}{l}\text { Authors' } \\
\text { judgement }\end{array}$ & Support for judgement \\
\hline $\begin{array}{l}\text { Random sequence generation (selection } \\
\text { bias) }\end{array}$ & Low Risk & $\begin{array}{l}\text { Trial investigators report "a computer-generated list was } \\
\text { used for random allocation of families" (page 1125, col }\end{array}$ \\
& & 2). The allocation sequence was adequately generated.
\end{tabular}




\begin{tabular}{|c|c|c|}
\hline Bias & $\begin{array}{l}\text { Authors' } \\
\text { judgement }\end{array}$ & Support for judgement \\
\hline Allocation concealment (selection bias) & Low Risk & $\begin{array}{l}\text { Trial investigators report "the administrator, therapists } \\
\text { and researchers were unaware of the randomisation } \\
\text { sequence. The sequence was stored in numbered, } \\
\text { opaque, tamper-proof envelopes, held by an } \\
\text { administrator who was not involved with recruitment, } \\
\text { therapy or evaluation. Following research assessments, } \\
\text { names of newly recruited families were passed to the } \\
\text { administrator who allocated families in strict order of } \\
\text { recruitment according to the next envelope in the } \\
\text { sequence" (page 1125, col 2). Review authors judge } \\
\text { that concealment through use of central administrator is } \\
\text { an acceptable method of minimising risk of bias. }\end{array}$ \\
\hline $\begin{array}{l}\text { Blinding (performance bias and detection } \\
\text { bias) } \\
\text { Participants }\end{array}$ & High Risk & $\begin{array}{l}\text { Review authors judge it is not possible to blind } \\
\text { participants in this type of study. In order to enhance } \\
\text { blindness of outcome assessors, the parents were } \\
\text { asked not to reveal intervention status to them (they } \\
\text { were reminded about it by letter, phone, and at each } \\
\text { visit) }\end{array}$ \\
\hline $\begin{array}{l}\text { Blinding (performance bias and detection } \\
\text { bias) } \\
\text { Personnel }\end{array}$ & Low Risk & $\begin{array}{l}\text { Trial investigators report "the administrator, therapists } \\
\text { and researchers were unaware of the randomisation } \\
\text { sequence' (page 1125, col 2). Several strategies were } \\
\text { used to enhance blindness of researchers: families } \\
\text { were reminded by letter, phone and at each visit not to } \\
\text { reveal intervention status. Researchers did not } \\
\text { administer consumer satisfaction questionnaires; these } \\
\text { were mailed to a different researcher for analysis. } \\
\text { Wherever possible, staff coded observation tapes of } \\
\text { families they had not themselves visited" (page 1126, } \\
\text { col 1). Review authors judge personnel were } \\
\text { adequately blinded. }\end{array}$ \\
\hline $\begin{array}{l}\text { Blinding (performance bias and detection } \\
\text { bias) } \\
\text { Outcome assessors }\end{array}$ & Low Risk & $\begin{array}{l}\text { Trial investigators report "all assessments were } \\
\text { conducted in the home by researchers who were } \\
\text { unaware of families' allocation" (page 1125). Review } \\
\text { authors judge knowledge of the allocated interventions } \\
\text { was adequately prevented regarding the outcome } \\
\text { assessors. }\end{array}$ \\
\hline Incomplete outcome data (attrition bias) & Low Risk & $\begin{array}{l}\text { At post-intervention point ( } 6 \text { months), 5/44 (11\%) } \\
\text { dropped out from treatment group and none dropped } \\
\text { out from the control group. Investigators report that }\end{array}$ \\
\hline
\end{tabular}




\begin{tabular}{|c|c|c|}
\hline Bias & $\begin{array}{l}\text { Authors' } \\
\text { judgement }\end{array}$ & Support for judgement \\
\hline & & $\begin{array}{l}\text { "families lost to follow-up did not differ significantly from } \\
\text { those retained' (page 1127, col 2), although reasons for } \\
\text { missing data not given. However, number given for } \\
\text { ANCOVAs at post-intervention was } 66 \text { (37 intervention } \\
\text { and } 29 \text { control) suggesting } 7 / 44 \text { (16\%) missing data } \\
\text { from intervention group and } 3 / 32 \text { (9\%) missing from } \\
\text { control group. }\end{array}$ \\
\hline Selective reporting (reporting bias) & Low Risk & $\begin{array}{l}\text { Review authors judge that the published report includes } \\
\text { all expected outcomes, including those that were pre- } \\
\text { specified. }\end{array}$ \\
\hline Other bias & Low Risk & $\begin{array}{l}\text { Study appeared to be free of other forms of bias. } \\
\text { Investigators note that the study was originally designed } \\
\text { as a 3-arm trial but was effectively reconfigured as a 2- } \\
\text { arm design due to poor recruitment. They describe how } \\
\text { they used the same allocation list throughout to ensure } \\
\text { families had the same probability of allocation to an } \\
\text { intervention condition as in the original protocol, and the } \\
11 \text { families allocated to the third arm ('Veritas' } \\
\text { programme) were not included in the analysis. }\end{array}$ \\
\hline
\end{tabular}




\subsubsection{Greaves 1997}

\begin{tabular}{ll}
\hline Methods & Parallel randomised controlled trial. \\
\hline Participants & Participants: mothers of pre-school children attending a centre for children with Down's syndrome. \\
& Sex: all mothers. \\
& Age of parents: not stated. \\
& Unit of allocation: individual participant. \\
& $\begin{array}{l}\text { Number randomised: } 54 \text { (21 intervention; } 17 \text { comparative-treatment; } 16 \text { control). } \\
\text { Number used in analysis: } 37 \text { (21 intervention; } 16 \text { control). }\end{array}$ \\
& $\begin{array}{l}\text { Country \& setting: Australia; single-site; recruited from community settings; intervention delivered in the } \\
\text { community. } \\
\text { Inclusion criteria: mothers of pre school children attending a centre for children with Down syndrome. }\end{array}$ \\
& $\begin{array}{l}\text { Exclusion criteria: not stated. } \\
\text { Ethnicity: not stated. } \\
\text { Baseline characteristics: not stated. }\end{array}$ \\
\hline Interventions & $\begin{array}{l}\text { Three condition: Rational Emotive parent education (cognitive-behavioural parenting programme); } \\
\text { Applied Behaviour Analysis programme; no-treatment control. } \\
\text { Duration of intervention: } 8 \text { weeks. } \\
\text { Length of follow-up: none. }\end{array}$ \\
\hline Notes & $\begin{array}{l}\text { Depressive symptoms (Parenting Stress Index). } \\
\text { Stress (Parenting Stress Index). } \\
\text { Anger (Berger Feeling Scale). } \\
\text { Guilt (Berger Feeling Scale). } \\
\text { Partner Satisfaction (Parenting Stress Index). }\end{array}$ \\
\hline Outcomes & \\
\hline
\end{tabular}

\section{Risk of bias table}

\begin{tabular}{|c|c|c|}
\hline Bias & Authors' judgement & Support for judgement \\
\hline $\begin{array}{l}\text { Random sequence generation (selection } \\
\text { bias) }\end{array}$ & Unclear risk & $\begin{array}{l}\text { Information reported insufficient for a judgement to } \\
\text { be made. We requested clarification from the trial } \\
\text { investigators, but no further information was } \\
\text { available at the time this review was prepared. }\end{array}$ \\
\hline Allocation concealment (selection bias) & Unclear risk & $\begin{array}{l}\text { Information reported insufficient for a judgement to } \\
\text { be made. We requested clarification from the trial } \\
\text { investigators, but no further information was } \\
\text { available at the time this review was prepared. }\end{array}$ \\
\hline $\begin{array}{l}\text { Blinding (performance bias and detection } \\
\text { bias) } \\
\text { Participants }\end{array}$ & High Risk & $\begin{array}{l}\text { Review authors judge that it would not be possible } \\
\text { to fully blind participants in this type of study, and } \\
\text { found no indication of any specific additional } \\
\text { measures taken to reduce the risk of bias that } \\
\text { might result from differential behaviours by }\end{array}$ \\
\hline
\end{tabular}




\begin{tabular}{|c|c|c|}
\hline Bias & Authors' judgement & Support for judgement \\
\hline & & participants. \\
\hline $\begin{array}{l}\text { Blinding (performance bias and detection } \\
\text { bias) } \\
\text { Personnel }\end{array}$ & Unclear risk & $\begin{array}{l}\text { Information reported insufficient for a judgement to } \\
\text { be made. We requested clarification from the trial } \\
\text { investigators, but no further information was } \\
\text { available at the time this review was prepared. }\end{array}$ \\
\hline $\begin{array}{l}\text { Blinding (performance bias and detection } \\
\text { bias) } \\
\text { Outcome assessors }\end{array}$ & Unclear risk & $\begin{array}{l}\text { Information reported insufficient for a judgement to } \\
\text { be made. We requested clarification from the trial } \\
\text { investigators, but no further information was } \\
\text { available at the time this review was prepared. }\end{array}$ \\
\hline Incomplete outcome data (attrition bias) & Low Risk & $\begin{array}{l}\text { Trial investigators do not report any missing data } \\
\text { for change scores at endpoint. They note that } \\
\text { participants did not complete measures at } 6 \text {-month } \\
\text { follow up, and present no follow up data. }\end{array}$ \\
\hline Selective reporting (reporting bias) & Low Risk & $\begin{array}{l}\text { Review authors judge that the published report } \\
\text { includes all expected outcomes, including those } \\
\text { that were pre-specified. }\end{array}$ \\
\hline Other bias & Low Risk & $\begin{array}{l}\text { The study appears to be free of other sources of } \\
\text { bias. }\end{array}$ \\
\hline
\end{tabular}

\subsubsection{Gross 1995}

\begin{tabular}{|c|c|}
\hline Methods & Parallel randomised controlled trial. \\
\hline Participants & $\begin{array}{l}\text { Participants: volunteer parents of toddlers with behaviour difficulties. } \\
\text { Sex: } 46 \text { mothers and fathers (no further information). } \\
\text { Age of parents: mean } 33 \text { years (SD 4.8) mothers; } 33 \text { years (SD 4.9) fathers. } \\
\text { Unit of allocation: individual family. } \\
\text { Number randomised: } 24 \text { (18 intervention; } 6 \text { control). } \\
\text { Number used in analysis: } 16 \text { (10 intervention; } 6 \text { control). } \\
\text { Country \& setting: USA; single-site; recruited from community settings; intervention delivered in the } \\
\text { community. } \\
\text { Inclusion criteria: both parents of child aged between } 24 \text { and } 36 \text { months who met criteria for } \\
\text { behavioural difficulties; parent willing to participate in a } 10 \text {-week intervention and complete a serious of } \\
\text { questionnaires and observations. } \\
\text { Exclusion criteria: not stated. } \\
\text { Ethnicity: } 80 \% \text { Caucasian mothers; } 75 \% \text { Caucasian fathers. } \\
\text { Baseline characteristics: median education among both parents was some college; unemployment: } 9 \\
\text { (37.5\%) mothers; } 1 \text { (4\%) father; } 20 \text { (83\%) boys. }\end{array}$ \\
\hline Interventions & $\begin{array}{l}\text { Two conditions: Webster-Stratton parenting programme; no-treatment control. } \\
\text { Duration of intervention: } 10 \text { weeks. }\end{array}$ \\
\hline
\end{tabular}


Length of follow-up: 3-months.

\begin{tabular}{ll}
\hline Outcomes & $\begin{array}{l}\text { Depressive symptoms (Center for Epidemiological Studies Depression Scale). } \\
\text { Stress (Parenting Stress Index). } \\
\text { Confidence (Toddler Care Questionnaire). }\end{array}$ \\
\hline Notes & \\
\hline
\end{tabular}

\section{Risk of bias table}

Bias

Authors' judgement Support for judgement

Random sequence generation (selection Low Risk bias)

Trial investigators report "the 24 families were randomly assigned to the intervention group $(n=18)$ or control group ( $n=6)$ " (page 490). Information reported insufficient for a judgement to be made, but information from trial investigator (email from D Gross to $\mathrm{NH}$ on 22 Oct 2010) indicates that a random numbers table was used.

Allocation concealment (selection bias) Low Risk Information reported insufficient for a judgement to be made, but information from trial investigator (email from D Gross to NH on 22 Oct 2010) indicates that concealment was achieved by use of a third party (a statistician).

Blinding (performance bias and detection High Risk bias)

Participants
Review authors judged that it would not be possible to fully blind participants in this type of study, and found no indication of any specific additional measures taken to reduce the risk of bias that might result from differential behaviours by participants.

Blinding (performance bias and detection High Risk bias)

Personnel
Information reported insufficient for a judgement to be made, but information from trial investigator (email from D Gross to NH on 22 Oct 2010) states that trial personnel could not be blinded "because we were running the intervention".

Information reported insufficient for a judgement to be made. Information from trial investigator (email from $D$ Gross to NH on 22 Oct 2010) states "research assistants collecting parent report data were not told which conditions parents were in, but parents may have shared the information. Research assistants coding the parent-child interactions only had access to video recorded parent-child data and were fully blinded to parent condition". 
Incomplete outcome data (attrition bias) High Risk

\begin{tabular}{lll} 
& $\begin{array}{l}\text { treatment group and 0/6 missing from control group. } \\
\text { Numbers do not appear to be balanced between } \\
\text { conditions. }\end{array}$ \\
\hline Selective reporting (reporting bias) & Low Risk & $\begin{array}{l}\text { Review authors judge that the published report } \\
\text { includes all expected outcomes, including those that } \\
\text { were pre-specified. }\end{array}$ \\
\hline Other bias & Low Risk & The study appears to be free of other sources of bias. \\
\hline
\end{tabular}

\subsubsection{Gross 2003}

\begin{tabular}{|c|c|}
\hline Methods & Cluster randomised controlled trial. \\
\hline Participants & 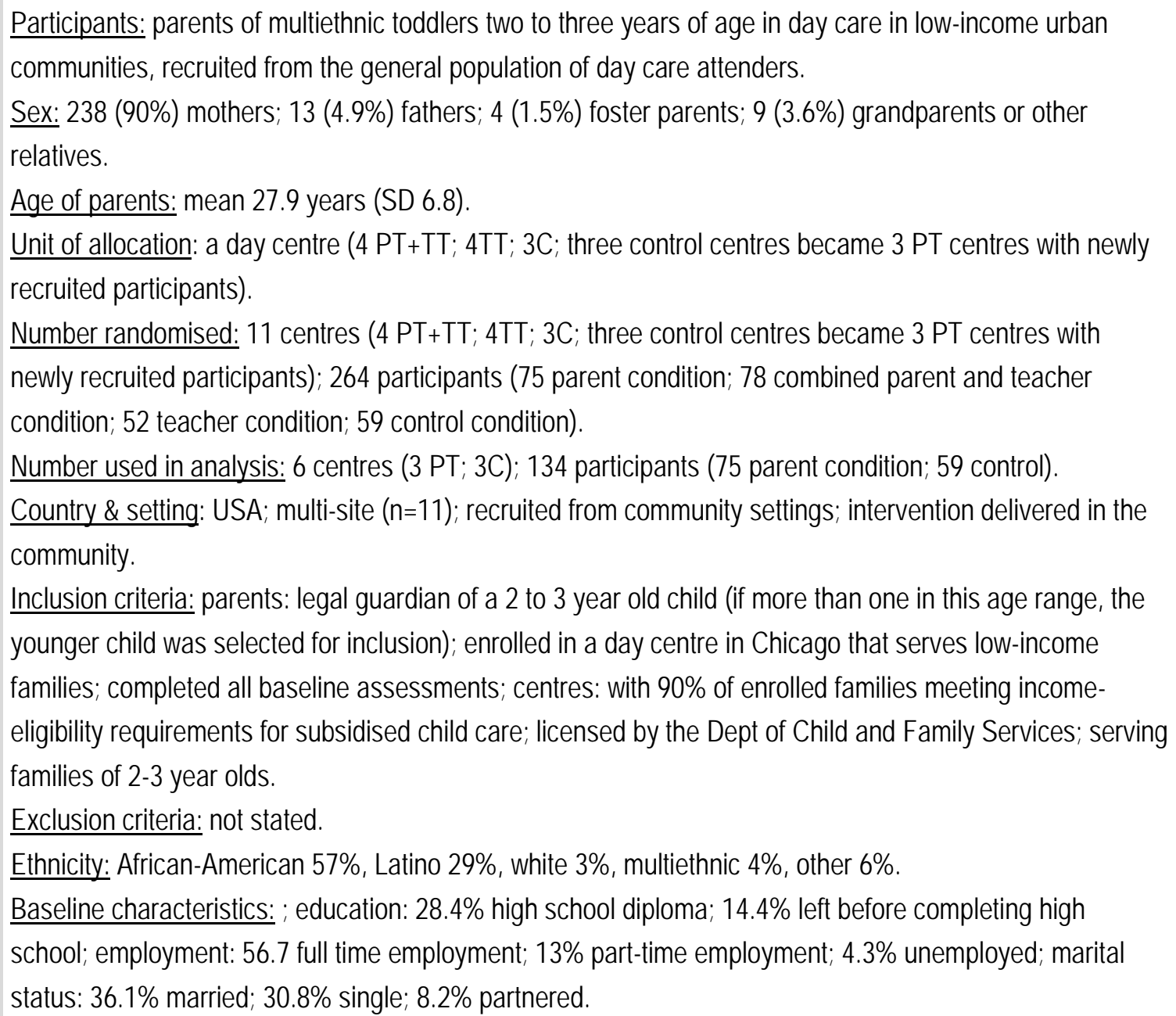 \\
\hline Interventions & $\begin{array}{l}\text { Four conditions: Webster-Stratton parent training (PT), parent and teacher training (PT plus TT); teacher } \\
\text { training (TT), wait-list control. Intervention consists of Incredible Years BASIC parenting programme. } \\
\text { Duration of intervention: } 12 \text { weeks. } \\
\text { Length of follow-up: } 6 \text { months; } 12 \text { months. }\end{array}$ \\
\hline Outcomes & $\begin{array}{l}\text { Depressive symptoms (Center for Epidemiological Studies Depression Scale). } \\
\text { Stress (Everyday Stress Index). }\end{array}$ \\
\hline
\end{tabular}


Confidence (Toddler Care Questionnaire).

Notes

\section{Risk of bias table}

Bias $\quad$ Authors' judgement Support for judgement

Random sequence generation (selection Low Risk Investigators report "centres were assigned to groups bias) of centres so that the grouped centres were matched on day care size, ethnic composition, percentage of single-parent families, median income, and day care centre quality. These grouped centres were than randomly assigned to one of three conditions: PT + TT $(n=4)$, TT $(n=4)$ or $C(n=3)$ conditions. C centres received no intervention for at least 1 years, after which new parents were recruited and these centres became PT centres" (page 263). Information reported insufficient for a judgement to be made, but information from trial investigator (email from $D$ Gross to $C B$ on 11 Oct 2010) indicates that a random numbers table was used.

Allocation concealment (selection bias) High Risk Information reported insufficient for a judgement to be made, but information from trial investigator (email from D Gross to CB on 11 Oct 2010) indicates that sealed opaque envelopes were not used.

Blinding (performance bias and detection High Risk bias)

Participants
Review authors judge that it would not be possible to fully blind participants in this type of study, and found no indication of any specific additional measures taken to reduce the risk of bias that might result from differential behaviours by participants.

Information reported insufficient for a judgement to be made, but information from trial investigator (email from D Gross to CB on 11 Oct 2010) state that "the research assistant collecting the surveys from parents could not be blinded".

Trial investigators report "videotaped play sessions were later coded by European American observers (in Seattle) who were blind to study hypotheses and participant's group assignment" (page 265). Outcome assessors were blinded for the 'observer rated child behaviour problems' outcome. However, no information for parent self-report measures. 
Incomplete outcome data (attrition bias) High Risk Trial investigators do not supply a full breakdown of missing data by allocation condition due to dropouts. They state that 47 were missing from the PT+TT condition and 9 missing from the TT and $\mathrm{C}$ conditions. Reasons for attrition given for the sample overall and not by allocation condition: 20 lack of time; 17 schedule conflicts; 12 too much stress; 4 child left day centre; 3 failed to attend; 3 staff unable to locate.

Additionally "the growth care models presented in this article are based on 208 participants who remained in the study. To assess the effects of dropouts on the results on these analyses, we also run the final growth curve on the initial sample of 246 participants. The pattern of significant parameters remained unchanged as a result of using the larger sample. This indicate that participants attrition did not modify the interpretation of results" (pages 266-277).

\begin{tabular}{lll} 
Selective reporting (reporting bias) & Low Risk & All prospectively stated outcomes were reported. \\
\hline Other bias & The study appears to be free of other sources of bias. \\
\hline
\end{tabular}

\subsubsection{Gross 2009}

\begin{tabular}{|c|c|}
\hline Methods & Cluster randomised controlled trial. \\
\hline Participants & $\begin{array}{l}\text { Participants: parents or legal guardians of a } 2-4 \text { year old child enrolled at the day care participating } \\
\text { centre. } \\
\text { Sex: } 225 \text { mothers, } 17 \text { fathers, } 4 \text { foster parent, } 5 \text { grandparents, and } 2 \text { other (sex of participants reported } \\
\text { only on } 253 \text { participants who were included in analysis). } \\
\text { Age of parents: not stated. } \\
\text { Unit of allocation: a day care centre. } \\
\text { Number randomised: } 7 \text { day centres ( } 3 \text { intervention; } 4 \text { control); } 292 \text { participants (156 intervention; } 136 \\
\text { control). } \\
\text { Number used in analysis: } 7 \text { day centres ( } 3 \text { intervention; } 4 \text { control); } 253 \text { participants ( } 135 \text { intervention; } \\
118 \text { control); number used in analysis for the 'depressive symptoms', 'stress' and 'confidence' outcomes: } \\
247 \text { (133 intervention; } 114 \text { control). } \\
\text { Country \& setting: USA; multi-site (n=7); recruited from community settings; intervention delivered in the } \\
\text { community. } \\
\text { Inclusion criteria: } \\
\text { Day care centre: had over } 90 \% \text { of enrolled families meeting income-eligibility requirements for } \\
\text { subsidised child care; was licensed by the Dept of Child and Family Services; provided full-day child } \\
\text { care; enrolled at least } 60 \text { children in the target age group; had a space on site to run a weekly parent }\end{array}$ \\
\hline
\end{tabular}




\begin{tabular}{|c|c|}
\hline & $\begin{array}{l}\text { group, and the director was willing to allow the site to be randomised. } \\
\text { Participant: a parent or a legal guardian of a } 2 \text { to } 4 \text { year old child (if more than one in this age range, the } \\
\text { youngest child was selected for inclusion); should speak English. } \\
\text { Exclusion criteria: not stated. } \\
\text { Ethnicity: } 149 \text { African-American, } 83 \text { Latino, } 12 \text { white (not Latino), } 9 \text { other (intervention group had more } \\
\text { Latino parents than control group, } P<0.01 \text { ). } \\
\text { Baseline characteristics: } \\
\text { There were no differences between two groups on parent age, educational level, employment status, } \\
\text { marital status, or child age; there were significant differences between these two groups on parent/race } \\
\text { ethnicity and child gender. }\end{array}$ \\
\hline Interventions & $\begin{array}{l}\text { Two conditions: Webster-Stratton parent programme; wait-list control. } \\
\text { Duration of intervention: } 12 \text { weeks. } \\
\text { Length of follow-up: } 6 \text { months; } 12 \text { months. }\end{array}$ \\
\hline Outcomes & $\begin{array}{l}\text { Depressive symptoms (Center for Epidemiological Studies Depression Scale). } \\
\text { Stress (Everyday Stress Index). } \\
\text { Confidence (Toddler Care Questionnaire). }\end{array}$ \\
\hline Notes & \\
\hline
\end{tabular}

\section{Risk of bias table}

\begin{tabular}{|c|c|c|}
\hline Bias & & Support for judgement \\
\hline $\begin{array}{l}\text { Random sequence generation (selection } \\
\text { bias) }\end{array}$ & Low Risk & $\begin{array}{l}\text { Trial investigators report "The day care centres were } \\
\text { matched on size, racial/ethnic composition, } \\
\text { percentage single-parent households, and median } \\
\text { income and randomly assigned to an intervention or } \\
\text { control condition" (page 56). Information reported } \\
\text { insufficient for a judgment to be made, but } \\
\text { information from trial investigator (email from D Gross } \\
\text { to CB on } 11 \text { Oct 2010) indicates that a random } \\
\text { numbers table was used. }\end{array}$ \\
\hline
\end{tabular}

\begin{tabular}{lll} 
Allocation concealment (selection bias) & High Risk & $\begin{array}{l}\text { Information reported insufficient for a judgment to be } \\
\text { made, but information from trial investigator (email } \\
\text { from D Gross to CB on 11 Oct 2010) indicates that } \\
\text { sealed opaque envelopes were not used. }\end{array}$ \\
\hline
\end{tabular}

Blinding (performance bias and detection High Risk bias)

Participants
Review authors judge that it would not be possible to fully blind participants in this type of study, and found no indication of any specific additional measures taken to reduce the risk of bias that might result from differential behaviours by participants.

Information reported insufficient for a judgment to be made, but information from trial investigator (email 


\section{Bias}

Personnel

\section{Support for judgement}

from D Gross to CB on 11 Oct 2010) stated that "the research assistant collecting the surveys from parents could not be blinded".

\section{Blinding (performance bias and detection Unclear Risk} bias)

Outcome assessors to CB on 11 Oct 2010) indicated that "the DPICS coders were blinded". However, no information for parent self-report measures. Information reported insufficient for a judgment to be made

The trial investigators report that "Thirty nine (13\%)
Incomplete outcome data (attrition bias) Low Risk

Information from trial investigator (email from D Gross participants dropped out of the study before their 1 year follow-up. Attrition in the control condition was attributed to 17 parents (12.5\%) who were lost to follow-up and 1 parent $(0.7 \%)$ who withdrew. Attrition in the intervention condition was attributed to 11 parents (7.1\%) lost to follow-up, 9 parents who withdrew, and 1 parents (5.8\%) who withdrew, and 1 parent who was dropped from the study due to emotional problems that interfered with her ability to participate in group discussion" (page 59).

For 'depressive symptoms', 'stress' and 'confidence' outcomes 23/156 participants (14.7\%) dropped out from treatment group and 18/136 participants dropped out from the control group (13.2\%). Review authors considered the numbers of and reasons for missing data reasonably likely to be balanced across the treatment conditions. Overall attrition was 14\%. Selective reporting (reporting bias) High Risk Low Risk
The three outcomes, 'depressive symptoms' (CESD), 'stress' (ESI) and 'confidence' (TCQ) were not prespecified, nor reported, although they were measured. The authors provided the data (email from D Gross to CB on 27/12/10) stated "We did not include them in the 2009 paper because of (1) length and (2) their lack of association with the outcome variables, and therefore, did not contribute to the results".

Trial investigators report "There were significant differences between intervention and control parents on parent race/ethnicity and child gender. To control for baseline differences, these variables were included as co-variates in the analytic models (page 


\subsubsection{Gutierrez 2007}

\begin{tabular}{|c|c|}
\hline Methods & Parallel randomised controlled trial. \\
\hline Participants & $\begin{array}{l}\text { Participants: Hispanic Spanish speaking mothers of a school-age child with behavioural and emotional } \\
\text { difficulties. } \\
\text { Sex: all mothers. } \\
\text { Age of parents: mean } 35.2 \text { years. } \\
\text { Unit of allocation: individual participant. } \\
\text { Number randomised: } 70 \text { (number randomised to the four conditions; no further information). } \\
\text { Number used in analysis: } 34 \text { (17 intervention; } 17 \text { wait-list control). } \\
\text { Country \& setting: USA; single site; recruited from community settings; intervention delivered in the } \\
\text { community. } \\
\text { Inclusion criteria: mother; Hispanic and Spanish speaking; migrant farm workers; having a school-age } \\
\text { child (enrolled in Kindergarten to } 5^{\text {th }} \text { grade) in Southern California; eligible to receive migrant education } \\
\text { services; referred by the school district's Student Assistance Program for students experiencing } \\
\text { behavioural and emotional problems. } \\
\text { Exclusion criteria: past or present involvement in a parent training program. } \\
\text { Ethnicity: } 100 \% \text { Spanish-speaking Hispanic. } \\
\text { Baseline characteristics: } 74 \% \text { married; } 16 \% \text { educated beyond } 12^{\text {th }} \text { grade; mean } 2.3 \text { children in family; } \\
\text { mean age of child = } 8.0 \text { years. }\end{array}$ \\
\hline Interventions & $\begin{array}{l}\text { Four conditions: Behavioural parenting program (BPP); STEP (a modified form of family therapy based } \\
\text { on Adlerian therapy); wait-list control; attention-placebo control. } \\
\text { Duration of intervention: } 8 \text { weeks. } \\
\text { Length of follow-up: } 3 \text { months. }\end{array}$ \\
\hline Outcomes & Stress (Parenting Stress Index). \\
\hline Notes & $\begin{array}{l}\text { We used data from the BPP arm only compared with wait-list control to avoid double counting of } \\
\text { participants in the control group. }\end{array}$ \\
\hline
\end{tabular}

\section{Risk of bias table}

\begin{tabular}{lll}
\hline Bias & Support for judgement \\
\hline $\begin{array}{l}\text { Random sequence generation (selection } \\
\text { bias) }\end{array}$ & Unclear Risk & $\begin{array}{l}\text { Information reported insufficient for a judgement to be } \\
\text { made. We requested clarification from the trial investigators, } \\
\text { but no further information was available at the time this } \\
\text { review was prepared. }\end{array}$ \\
\hline Allocation concealment (selection bias) & Unclear Risk & $\begin{array}{l}\text { Information reported insufficient for a judgement to be } \\
\text { made. We requested clarification from the trial investigators, } \\
\text { but no further information was available at the time this }\end{array}$ \\
\hline
\end{tabular}




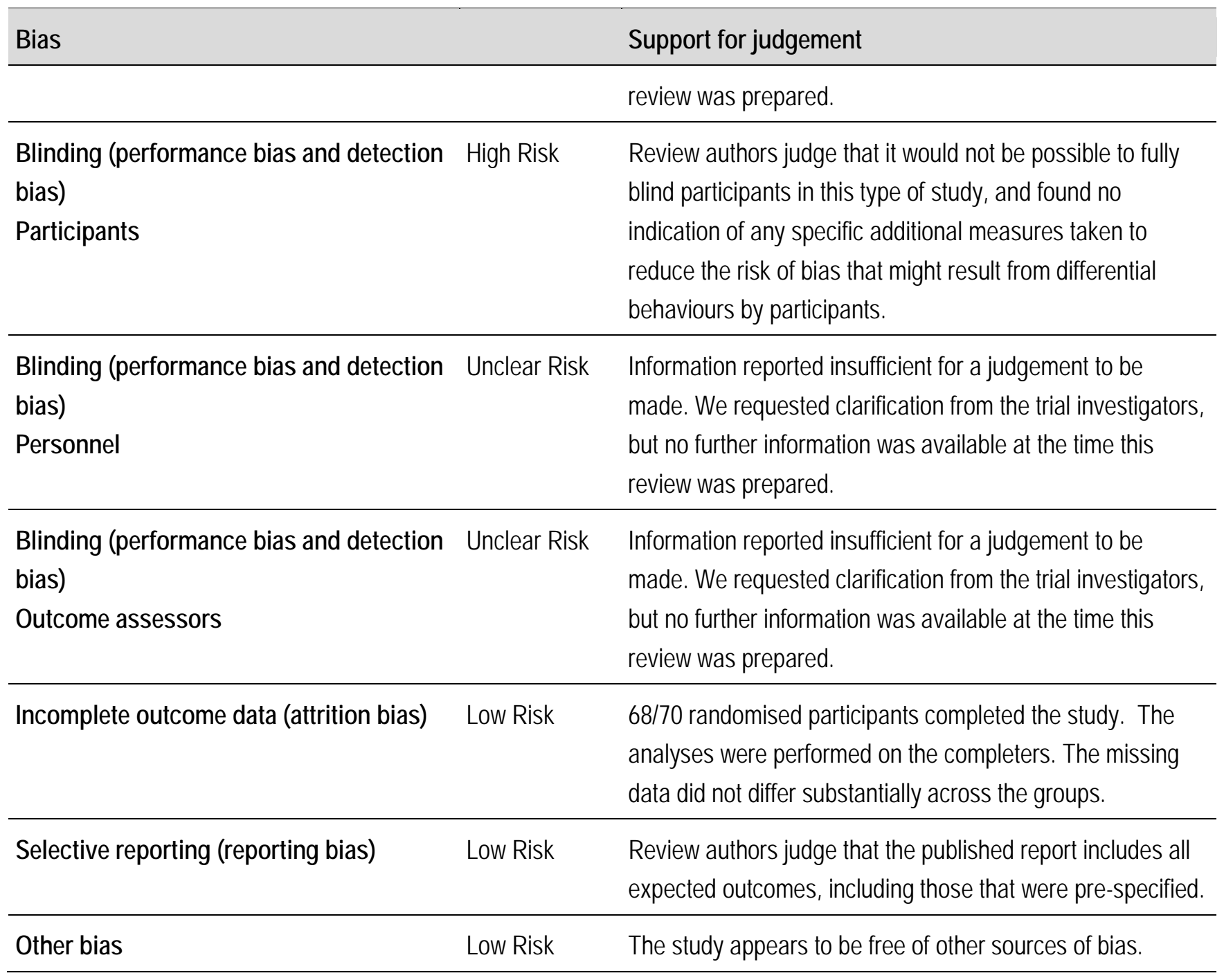

\subsubsection{Hanisch 2010}

\begin{tabular}{|c|c|}
\hline Methods & luster randomised controlled trial. \\
\hline Participants & $\begin{array}{l}\text { Participants: parents of children aged between } 3 \text { and } 6 \text { years, who were attending kindergartens. } \\
\text { Sex: both mothers and fathers (no further information). } \\
\text { Age of parents: not stated. } \\
\text { Unit of allocation: kindergarten. } \\
\text { Number randomised: } 58 \text { kindergartens randomised ( } 32 \text { intervention; } 26 \text { control); } 155 \text { participants } \\
\text { randomised ( } 91 \text { intervention group, } 64 \text { control). } \\
\text { Number used in analysis: } 54 \text { kindergartens ( } 31 \text { intervention; } 23 \text { control); } 121 \text { families ( } 75 \text { intervention; } 46 \\
\text { control). } \\
\text { Country \& setting: Germany; multi-site ( } n=54) ; \text { recruited from community settings; intervention delivered in } \\
\text { the community. } \\
\text { Inclusion criteria: families with children aged } 3-6 \text { years; children with externalising behavioural problems } \\
\text { indicated by scores above the } 85^{\text {th }} \text { percentile for scores on a screening instrument derived from the Child } \\
\text { Behaviour Checklist. } \\
\text { Exclusion criteria: not stated. } \\
\text { Ethnicity: not stated. }\end{array}$ \\
\hline
\end{tabular}


Baseline characteristics: mean CBCL scores: 43.14 (SD 20.99) and 39.72 (SD 19.35); mean motherassessed symptoms: 0.11 (SD 0.84) and -0.14 (SD 0.75).

\begin{tabular}{|c|c|}
\hline Interventions & $\begin{array}{l}\text { Two conditions: Prevention Programme for Externalising Problem behaviour (behavioural parenting } \\
\text { programme); no-treatment control. } \\
\text { Duration of intervention: } 10 \text { weeks. } \\
\text { Length of follow-up: } 8 \text { weeks. }\end{array}$ \\
\hline Outcomes & $\begin{array}{l}\text { Depressive symptoms (Depressive Anxiety Stress Scale). } \\
\text { Anxiety symptoms (Depressive Anxiety Stress Scale). } \\
\text { Stress (Depressive Anxiety Stress Scale). }\end{array}$ \\
\hline
\end{tabular}

\section{Risk of bias table}

Bias Support for judgement

Random sequence generation (selection Low Risk Trial investigators report "each of the kindergartens was bias) randomly assigned to either the intervention group of the control group so that any one teacher was not simultaneously teaching children in both groups" (page 98). Information reported insufficient for a judgement to be made. The trial investigator (e-mail from $\mathrm{C}$ Hanisch to CB. on 19 Nov 2010) confirmed that states that lots corresponding to participating kindergartens were drawn manually.

$\begin{array}{ll}\text { Allocation concealment (selection bias) } \quad \text { Unclear Risk } & \text { Information reported insufficient for a judgement to be } \\ & \text { made. We requested clarification from the trial } \\ & \text { investigators, but no further information was available at } \\ & \text { the time this review was prepared. }\end{array}$

Blinding (performance bias and detection High Risk bias)

Participants
Review authors judge that it would not be possible to fully blind participants in this type of study, and found no indication of any specific additional measures taken to reduce the risk of bias that might result from differential behaviours by participants.
Blinding (performance bias and detection High Risk bias)

Personnel
'Research assistants were blind to treatment group membership' (page 99). However: 'the blindness of the research assistants to the family's group membership could not be fully guaranteed as a few families gave away their group membership during the home visit' (page 107).

Trial investigators report "research assistants were blind to treatment group membership' (page 99). However, "the blindness of the research assistants to the family's group membership could not be fully guaranteed as a few 


\begin{tabular}{|c|c|c|}
\hline \multicolumn{2}{|l|}{ Bias } & \multirow{2}{*}{$\begin{array}{l}\text { Support for judgement } \\
\text { families gave away their group membership during the } \\
\text { home visit" (page 107). }\end{array}$} \\
\hline & & \\
\hline Incomplete outcome data (attrition bias) & Low Risk & $\begin{array}{l}\text { 16/91 (18\%) missing from experimental group (families } \\
\text { declined to participate), and 18/64 (28\%) missing from } \\
\text { control group (families declined to participate). Trial } \\
\text { investigators report "the pre-test composite scores for } \\
\text { families that dropped out of the study between the pre- and } \\
\text { post-tests did not differ from those that remained in the } \\
\text { study. However, mothers who dropped out after the pre- } \\
\text { test assessment had a lower level of education than those } \\
\text { who remained in the study ( } P<.001) \text { " (page } 103 \text { ). }\end{array}$ \\
\hline Selective reporting (reporting bias) & Low Risk & $\begin{array}{l}\text { Review authors judge that the published report includes all } \\
\text { expected outcomes, including those that were pre- } \\
\text { specified. }\end{array}$ \\
\hline Other bias & Low Risk & $\begin{array}{l}\text { The study appeared free of other forms of bias. "There } \\
\text { were no significant differences between these groups for } \\
\text { children's age and gender, or symptom severity on the } \\
\mathrm{CBCL} \text { total, PCL, ADHD, or PCL ODD. Mothers and } \\
\text { fathers of both groups reported similar levels of school } \\
\text { education and vocational training". However, ". . children } \\
\text { in the intervention group were rated as more severely } \\
\text { impaired than children in the control group" (page 103). }\end{array}$ \\
\hline
\end{tabular}

\subsubsection{Hiscock 2008}

\begin{tabular}{|c|c|}
\hline Methods & luster randomised controlled trial. \\
\hline Participants & $\begin{array}{l}\text { Participants: English speaking mothers of } 8 \text { months old children attending primary care nursing centres. } \\
\text { Sex: all mothers. } \\
\text { Age of parents: mean } 33 \text { years (SD 4.8) intervention; } 33.3 \text { years (SD 4.7) control. } \\
\text { Unit of allocation: centre. } \\
\text { Number randomised: } 40 \text { cluster centres, } 733 \text { families (18 centres and } 329 \text { families intervention; } 22 \\
\text { centres and } 404 \text { families control) } \\
\text { Number used in analysis: } 654-671 \text { families (291-298 intervention; } 363-373 \text { control). } \\
\text { Country \& setting: Australia; multi-site ( } n=40) \text {; recruited from community settings; intervention delivered } \\
\text { in the community. } \\
\text { Inclusion criteria: English speaking mothers of } 8 \text { month-old children attending well-child appointments. } \\
\text { Exclusion criteria: mothers with insufficient English to complete the questionnaires. } \\
\text { Ethnicity: not stated. } \\
\text { Baseline characteristics: married or cohabiting ( } 96.7 \% \text { intervention; } 96.5 \% \text { control); employment (25\% } \\
\text { intervention; } 29.7 \% \text { control); English spoken at home ( } 96.4 \% \text { intervention; } 95.8 \% \text { control); education: }\end{array}$ \\
\hline
\end{tabular}




\begin{tabular}{ll}
\hline & did not complete high school (19.8\% intervention; 21\% control); completed high school (34.5\% \\
& intervention; $32.2 \%$ control); completed tertiary/postgraduate (45.7\% intervention; $46.8 \%$ control). \\
& Mental health: depression score (mean=4.1, SD=5.4 intervention group; mean=3.5, SD=4.5 control); \\
& depressed (14\% intervention group; $9.2 \%$ control); anxiety score (mean=2.2, SD=3.6 intervention \\
& group; mean=1.9, SD=3.1 control); anxious ( $9.8 \%$ intervention group; $6.7 \%$ control); stress score \\
& (mean=9.0, SD=6.5 intervention group; mean=8.8, SD=6.3 control); stressed (14\% intervention group; \\
& $12.4 \%$ control). \\
\hline \multirow{2}{*}{ Interventions } & Two conditions: universal parenting (behavioural parenting) programme; treatment as usual control. \\
& Duration of intervention: 7 months. \\
& Duration of trial: 16 months. \\
& Length of follow-up: 3 months; 9 months. \\
\hline Outcomes & Depressive symptoms (Depression Anxiety Stress Scales). \\
& Anxiety symptoms (Depression Anxiety Stress Scales). \\
& Stress (Depression Anxiety Stress Scales). \\
\hline Notes & \\
\hline
\end{tabular}

\section{Risk of bias table}

\begin{tabular}{ll}
\hline Bias & Support for judgement \\
\hline $\begin{array}{l}\text { Random sequence generation (selection } \\
\text { bias) }\end{array}$ & $\begin{array}{l}\text { Investigators report "as we considered balance on } \\
\text { socioeconomic status to be important, } \\
\text { randomisation was done with a computer }\end{array}$ \\
& $\begin{array}{l}\text { generated allocation sequence by matching pairs } \\
\text { of centres according to their closeness of their }\end{array}$ \\
& $\begin{array}{l}\text { average socioeconomic disadvantage scores and } \\
\text { then randomising one centre from each pair to the } \\
\text { intervention arm" (page 3, col 2). Random } \\
\text { sequence allocation by computer-generated } \\
\text { random numbers. }\end{array}$ \\
\hline
\end{tabular}

Allocation concealment (selection bias) Low Risk
Investigators report "an independent statistician randomly allocated maternal and child health centres (and therefore their families), stratified by local government area, to intervention and control arms. Within each of the local government areas, a list of participating centres was created" (page 3 , col 2). Concealment achieved by use of central allocation (an independent statistician) such that participants and any investigator enrolling participants could not foresee assignment.

Review authors judge that it would not be possible to fully blind participants in this type of study, and found no indication of any specific additional 
measures taken to reduce the risk of bias that might result from differential behaviours by participants.

Blinding (performance bias and detection High Risk bias)

Personnel
Information reported insufficient for a judgement to be made but information from trial investigator (email from H Hiscock to CB on 11 Oct 2010) states "the trial personnel were not blinded to the family group (intervention or control) status as we coordinated the bookings of their group sessions".

Blinding (performance bias and detection Low Risk bias)

Outcome assessors
Information reported insufficient for a judgement to be made, but information from trial investigator (email from H.Hiscock to CB on 11 Oct 2010) states "all outcomes were collected by questionnaire and we remained blinded to family group status during data collection and analyses. Analyses were done by a statistician who was independent of study recruitment and intervention delivery".
Data for $31 / 329$ (9.4\%) missing from the intervention condition (failure to return questionnaires in each case), and for 30/404 (7.4\%) from the control condition (by 18 month evaluation point). Data for $37 / 329$ (11.2\%) missing from the intervention condition (failure to return questionnaires in each case), and for 40/404 (9.9\%) from the control condition (by 24 month evaluation point). Review authors considered the numbers of and reasons for missing data reasonably likely to be balanced across the treatment conditions. Overall attrition was 9.5\%.

Review authors judge that the published report includes all expected outcomes, including those that were pre-specified.

The study appeared to be free of other sources of bias. 


\subsubsection{Hutchings 2007}

\begin{tabular}{|c|c|}
\hline Methods & Parallel randomised controlled trial. \\
\hline Participants & $\begin{array}{l}\text { Participants: parents from socially disadvantaged families, recruited from } 11 \text { Sure Start areas. } \\
\text { Sex: both mothers and fathers (no further information). } \\
\text { Age: not reported for parents; children: control group, mean } 46.2 \text { (SD 4.2) months; intervention group, } \\
\text { mean } 46.4 \text { (SD 6.6) months. } \\
\text { Unit of allocation: parent-index child pair. } \\
\text { Number randomised: } 153 \text { (104 intervention; } 49 \text { control). } \\
\text { Number used in analysis: } 153 \text { (104 intervention; } 49 \text { control). } \\
\text { Country \& setting: UK; multi-site ( } n=11) \text {; recruited from community settings; intervention delivered in the } \\
\text { community. } \\
\text { Inclusion criteria: socially disadvantaged families with a child aged } 3 \text { or } 4 \text { years; child living with primary } \\
\text { carer; child scoring above the clinical cut-off on either the Eyberg problem or the Eyberg intensity scale } \\
\text { (11 or } 127) ; \text { primary carer able to attend at group times. } \\
\text { Exclusion criteria: none reported. } \\
\text { Ethnicity: } 14 \% \text { of children were Welsh speaking; } 41 \% \text { single parents; mean age of mother at birth of } \\
\text { first child } 20.5 \text { (control) and } 21.4 \text { years (intervention). } \\
\text { Baseline characteristics: target child: } 57 \% \text { boys intervention; } 66 \% \text { boys control. }\end{array}$ \\
\hline interventions & $\begin{array}{l}\text { Two conditions: Webster-Stratton 'Incredible Years' parenting programme; wait-list control. } \\
\text { Duration of intervention: } 12 \text { weeks. } \\
\text { Length of follow up: } 6 \text { months. }\end{array}$ \\
\hline Outcomes & $\begin{array}{l}\text { Depressive symptoms (Beck Depression Inventory). } \\
\text { Stress (Parenting Stress Index). }\end{array}$ \\
\hline
\end{tabular}

\section{Risk of bias table}

Bias

Random sequence generation (selection Low Risk bias)

\section{Support for judgement}

Trial investigators report that "participants were blocked randomised by area after stratification by sex and age, using a random number generator" (p.3, col 2). Random sequence allocation by computer-generated random numbers.

Information reported insufficient for a judgement to be made. We requested clarification from the trial investigators, but no further information was available at the time this review was prepared.

Review authors judge that it would not be possible to fully blind participants in this type of study, and found no indication of any specific additional measures taken to reduce the risk of bias that 
might result from differential behaviours by participants.

Blinding (performance bias and detection Low Risk bias)

Personnel
Trial investigators report "researchers blind to allocation carried out interviews and observations" (p.3, col 2). Review authors judge that personnel were blinded.

Trial investigators report "observers were blind to

Blinding (performance bias and detection Unclear Risk bias)

Outcome assessors allocation" (p.3, col 1). No specific details given on blinding of those who scored the self-report (questionnaire) outcome measures used in this review. We requested clarification from the trial investigators, but no further information was available at the time this review was prepared.

Data for 18/104 (17\%) were missing from the intervention condition (9 formally withdrew before intervention; 9 could not be contacted), and for 2/49 (4\%) from the control condition (1 formally withdrew before follow up; 1 could not be contacted). Thus although numbers of missing data do not balance between condition, the reasons for the missing data do not appear to differ substantially across the groups. Review authors judge incomplete data were adequately addressed. Overall attrition was $10.5 \%$.

Review authors judge that the published report includes all expected outcomes, including those that were pre-specified.

Other bias

High Risk
Investigators report "Competing interests: JH is paid by Incredible Years for running occasional training courses in the delivery of the parent programme ..." (page 7600).

This study appears to be free of other forms of bias. 


\subsubsection{Irvine 1999}

\begin{tabular}{|c|c|}
\hline Methods & Parallel randomised controlled trial. \\
\hline Participants & $\begin{array}{l}\text { Participants: families of at-risk middle school students. } \\
\text { Sex: both mothers and fathers (no further information). } \\
\text { Age of parents: intervention: } 36.6 \text { years (SD 5.4) mothers; } 39.3 \text { years (SD 7.1) fathers; control: } 37.7 \\
\text { years (SD 6.97) mothers; } 39.7 \text { years (SD 7.07) fathers. } \\
\text { Unit of allocation: individual family. } \\
\text { Number randomised: } 303 \text { ( } 151 \text { intervention; } 152 \text { control). } \\
\text { Number used in analysis: } 241 \text { (106 intervention; } 135 \text { control) at post-intervention; } 161 \text { ( } 67 \\
\text { intervention; } 94 \text { control) at } 6 \text { month follow-up; } 109 \text { ( } 51 \text { intervention; } 58 \text { control) at } 12 \text { month follow- } \\
\text { up. } \\
\text { Country \& setting: USA; multi-site (n=8); recruited from community settings; intervention delivered in } \\
\text { the community. } \\
\text { Inclusion criteria: students with more than three risk factors referred by school or by social service } \\
\text { agency staff; the risk factors were: behavioural, externalising, substance use, deviant peer } \\
\text { associations, academic deficiencies, and family stress. } \\
\text { Exclusion criteria: families currently receiving other treatment. } \\
\text { Ethnicity: } 88 \% \text { Caucasian. } \\
\text { Baseline characteristics: there were no significant differences between conditions on family status, } \\
\text { education, cultural background or target child's gender. }\end{array}$ \\
\hline Interventions & $\begin{array}{l}\text { Two condition: adolescent transition programme (behavioural parenting programme); wait-list } \\
\text { control. } \\
\text { Duration of intervention: } 12 \text { weeks. } \\
\text { Duration of trial: } 4 \text { years. } \\
\text { Length of follow-up: } 3 \text { months, } 6 \text { months; } 12 \text { months. }\end{array}$ \\
\hline Outcomes & Depressive symptoms (Beck Depression Inventory). \\
\hline & \\
\hline
\end{tabular}

\section{Risk of bias table}

Bias

Random sequence generation (selection Low Risk bias)

\section{Support for judgement}

Trial investigators report that families "were randomly assigned to a condition immediately following their recruitment" (page 813). Information from trial investigator (email from $\mathrm{B}$ Irvine to $\mathrm{NH}$ on 22 Oct 2010) indicates that a random numbers table was used.

Information reported insufficient for a judgement to be made. Information from trial investigator (e-mail from B Irvine to NH on 22 Oct 2010) indicates that allocation concealment was achieved through use 
of a central allocation facility.

Blinding (performance bias and detection High Risk bias)

Participants
Review authors judged that it would not be possible to fully blind participants in this type of study, and found no indication of any specific additional measures taken to reduce the risk of bias that might result from differential behaviours by participants.

Information reported insufficient for a judgement to be made. Information from trial investigator (email from B Irvine to NH on 22 Oct 2010) indicates that personnel were not blinded.

Information reported insufficient for a judgement to be made. Information from trial investigator (email from B Irvine to NH on 22 Oct 2010) states that the term 'outcome assessors' was not generally relevant to this study but that "most data were collected via mailed parent surveys". Phone interviewers "did know the allocation status" but "coders of the phone interview recordings did not know the allocation status".

Rates of attrition at post-treatment were 45/151 (30\%) in the treatment group and 17/152 (11\%) in the control group, and at 6-month follow up were $84 / 151(56 \%)$ in the treatment group and 58/152 $(38 \%)$ in the control group. Although numbers of missing data were not balanced between conditions, trial investigators conducted a comparison on each of the dependent variables, looking for a main effect between study drop out and the remaining participants across all of the subsequent time points and found that the study dropouts and the parents who remained differed on only one variable (the laxness scale of the PSA that measures parental limit setting).

Review authors judge that the published report includes all expected outcomes, including those that were pre-specified.

The study appears to be free of other sources of bias. 


\subsubsection{J oachim 2010}

\begin{tabular}{|c|c|}
\hline Methods & Parallel randomised controlled trial. \\
\hline Participants & $\begin{array}{l}\text { Participants: parents of } 2 \text { to } 6 \text { year old children showing problem behaviour during shopping trips. } \\
\text { Sex: } 44 \text { mothers; } 2 \text { fathers. } \\
\text { Age of parents: mean } 33.78 \text { years (SD 5.21). } \\
\text { Unit of allocation: individual participant. } \\
\text { Number randomised: } 46 \text { ( } 26 \text { intervention; } 20 \text { control). } \\
\text { Number used in analysis: } 40 \text { ( } 22 \text { intervention; } 18 \text { control). } \\
\text { Country \& setting: Australia; single-site; recruited from community settings; intervention delivered in } \\
\text { the community. } \\
\text { Inclusion criteria: parents of } 2 \text { to } 6 \text { year old children showing problem behaviour during shopping trips; } \\
\text { residing within Brisbane metropolitan area. Data gathered from one parent only, usually the mother (or } \\
\text { the father if he was the primary caregiver). } \\
\text { Exclusion criteria: child had a disability; child had a chronic illness; parents currently consulting a } \\
\text { professional for child behaviour difficulties or other personal problems } \\
\text { Ethnicity: } 91 \% \text { Australian ethnic background. } \\
\text { Baseline characteristics: } 52 \% \text { employed; } 78.3 \% \text { of children lived with parent who were married; target } \\
\text { child: } 54.3 \% \text { boys; } 45.7 \% \text { girls. }\end{array}$ \\
\hline Interventions & $\begin{array}{l}\text { Two conditions: brief parent discussion programme (Triple-P parenting programme); wait-list control. } \\
\text { Duration of intervention: two hours. } \\
\text { Length of follow-up: } 6 \text { months. }\end{array}$ \\
\hline Outcomes & $\begin{array}{l}\text { Depressive (Depression Anxiety Stress Scales). } \\
\text { Anxiety symptoms (Depression Anxiety Stress Scales). } \\
\text { Stress (Depression Anxiety Stress Scales). } \\
\text { Confidence (Parenting Task Checklist). }\end{array}$ \\
\hline & \\
\hline
\end{tabular}

\section{Risk of bias table}

Bias

Random sequence generation (selection Low Risk bias)

\section{Support for judgement}

Information reported insufficient for a judgement to be made, but information from trial investigator (email from S Joachim to CB on 27 Oct 2010) indicates that computer generated random numbers were used.

Information reported insufficient for a judgement to be made. but information from trial investigator (email from S Joachim to CB on 27 Oct 2010) states "families were assigned sequentially to condition according to the list". 


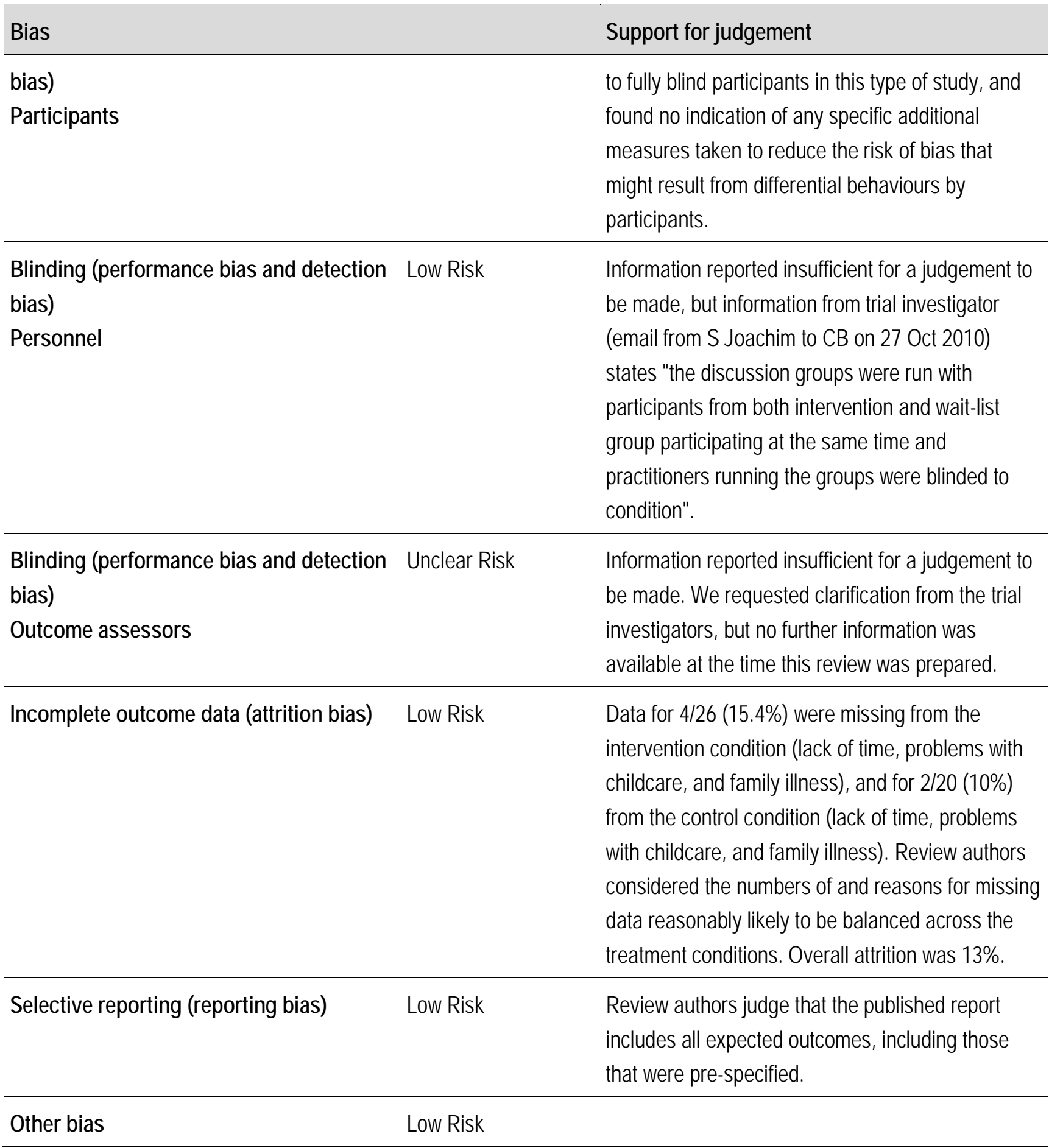

\subsubsection{J oyce 1995}

\begin{tabular}{|c|c|}
\hline Methods & Parallel randomised controlled trial. \\
\hline \multirow[t]{6}{*}{ Participants } & Participants: volunteer parents with elementary school aged children. \\
\hline & Sex: 35 (73\%) mothers; (27\%) 13 fathers. $12 / 48$ (25\%) were parents from one family. \\
\hline & Age of participants: not stated. \\
\hline & Unit of allocation: individual participant. \\
\hline & Number randomised: 48 (32 intervention; 16 control). \\
\hline & Number used in analysis: 48 (32 intervention; 16 control). \\
\hline
\end{tabular}


Country \& setting: Australia; single-site; recruited from community settings; intervention delivered in the community.

Inclusion criteria: non-clinical parent population of elementary school aged children in a private school in Melbourne.

Exclusion criteria: not stated.

Ethnicity: not stated.

Baseline characteristics: marital status: no single or divorced parents; one widow; sample was heterogeneous with respect to educational level.

\begin{tabular}{|c|c|}
\hline Interventions & $\begin{array}{l}\text { Two conditions: Rational Emotive parent education (cognitive-behavioural parenting programme); wait- } \\
\text { list control. } \\
\text { Duration of intervention: } 9 \text { sessions (assumed } 9 \text { weeks). } \\
\text { Length of follow-up: no follow-up. }\end{array}$ \\
\hline Outcomes & $\begin{array}{l}\text { Anxiety symptoms (State-Trait Anxiety Inventory). } \\
\text { Anger (Berger Feeling Scale). } \\
\text { Guilt (Berger Feeling Scale). }\end{array}$ \\
\hline
\end{tabular}

\section{Risk of bias table}

Bias

Random sequence generation (selection Unclear Risk bias)

\section{Support for judgement}

Trial investigators report that parents "were randomly assigned to four experimental and two control groups; the two group leaders were then randomly assigned to the experimental groups" (page 58). Information reported insufficient for a judgement to be made. We requested clarification from the trial investigators, but no further information was available at the time this review was prepared.

Allocation concealment (selection bias) Unclear Risk Information reported insufficient for a judgement to be made. We requested clarification from the trial investigators, but no further information was available at the time this review was prepared.

Blinding (performance bias and detection High Risk bias) Review authors judged that it would not be possible to fully blind participants in this type of study, and found no indication of any specific additional measures taken to reduce the risk of bias that might result from differential behaviours by participants.

Blinding (performance bias and detection Unclear Risk bias)

Information reported insufficient for a judgement to be made. We requested clarification from the trial 


\begin{tabular}{|c|c|c|}
\hline Bias & & Support for judgement \\
\hline Personnel & & $\begin{array}{l}\text { investigators, but no further information was } \\
\text { available at the time this review was prepared. }\end{array}$ \\
\hline $\begin{array}{l}\text { Blinding (performance bias and detection } \\
\text { bias) } \\
\text { Outcome assessors }\end{array}$ & Unclear Risk & $\begin{array}{l}\text { Information reported insufficient for a judgement to } \\
\text { be made. We requested clarification from the trial } \\
\text { investigators, but no further information was } \\
\text { available at the time this review was prepared. }\end{array}$ \\
\hline Incomplete outcome data (attrition bias) & Unclear Risk & $\begin{array}{l}\text { Unclear whether there was missing data. We } \\
\text { requested clarification from the trial investigators, } \\
\text { but no further information was available at the time } \\
\text { this review was prepared. }\end{array}$ \\
\hline Selective reporting (reporting bias) & Low Risk & $\begin{array}{l}\text { Review authors judge that the published report } \\
\text { includes all expected outcomes, including those } \\
\text { that were pre-specified. }\end{array}$ \\
\hline Other bias & Low Risk & $\begin{array}{l}\text { The study appears to be free of other sources of } \\
\text { bias. }\end{array}$ \\
\hline
\end{tabular}

\subsubsection{Larsson 2009}

\begin{tabular}{|c|c|}
\hline Methods & Parallel randomised controlled trial. \\
\hline Participants & $\begin{array}{l}\text { Participants: parents of } 4 \text { to } 8 \text { year old children with oppositional or conduct problems. } \\
\text { Sex: both mothers and fathers (no further information). } \\
\text { Age of parents: mothers: mean } 33.7 \text { years (SD 6.3) intervention; mean } 34.9 \text { years (SD 6.8) control; } \\
\text { fathers: mean } 35.2 \text { years (SD 5.7) intervention; mean } 37.0 \text { years (SD 8.0). } \\
\text { Unit of allocation: individual family. } \\
\text { Number randomised: } 127 \text { ( } 47 \text { parent training group; } 52 \text { parent plus child training group; } 28 \text { control } \\
\text { group). } \\
\text { Number used in analysis: } 71 \text { ( } 43 \text { parent training group; } 28 \text { control). } \\
\text { Country \& setting: Norway; multi-site (n=2); recruited from outpatient settings; intervention delivered in } \\
\text { an outpatient clinic. } \\
\text { Inclusion criteria: parents of } 4 \text { to } 8 \text { year old children with sub-threshold or clinical diagnosis of } \\
\text { oppositional defiant disorder and/or conduct disorder according to DSM-IV criteria. } \\
\text { Exclusion criteria: parents of children with gross physical impairment; sensory deprivation; intellectual } \\
\text { deficit; autism; receiving another psychotherapeutic intervention; receiving medication for ADHD unless } \\
\text { this initiated >6 months prior to study entry. } \\
\text { Ethnicity: } 80 \text { families were native Norwegians. } \\
\text { Baseline characteristics: one parent families: mean } 16 \text { (SD 37.2) intervention; mean } 8 \text { (SD=32.0) } \\
\text { control; mothers not completing high school: mean } 11 \text { (SD 23.9) intervention; mean } 8 \text { (SD=33.3) } \\
\text { control; fathers not completing high school: mean } 9 \text { (SD 25.0) intervention; mean } 6 \text { (SD=31.6) control; } \\
\text { target child: } 60 \text { (80\%) boys. }\end{array}$ \\
\hline
\end{tabular}




\begin{tabular}{ll}
\hline Interventions & Three conditions: Basic Webster-Stratton Incredible Years parenting program; Basic Incredible Years \\
& Parenting Program plus child treatment; wait-list control. \\
& Duration of intervention: 12 to 14 weeks. \\
& Length of follow-up: 12 months (the design resulted in loss of control group to follow-up). \\
\hline Outcomes & Stress (Parenting Stress Index). \\
\hline Notes & \\
\hline
\end{tabular}

\section{Risk of bias table}

Bias

\section{Support for judgement}

Random sequence generation (selection Unclear Risk bias)

Information reported insufficient for a judgement to be made. We requested clarification from the trial investigators, but no further information was available at the time this review was prepared.

Allocation concealment (selection bias) Unclear Risk Information reported insufficient for a judgement to be made. We requested clarification from the trial investigators, but no further information was available at the time this review was prepared.

Blinding (performance bias and detection High Risk bias)

Participants
Review authors judge that it would not be possible to fully blind participants in this type of study, and found no indication of any specific additional measures taken to reduce the risk of bias that might result from differential behaviours by participants.

Information reported insufficient for a judgement to be made. We requested clarification from the trial investigators, but no further information was available at the time this review was prepared.

Information reported insufficient for a judgement to be made. We requested clarification from the trial investigators, but no further information was available at the time this review was prepared.

Data for $6 / 51$ (12\%) were missing from the intervention condition (4 never started, 2 dropped out; reasons not given), and for $2 / 30$ (7\%) from the control condition (2 withdrew; reasons not given). Review authors considered the numbers of missing data reasonably likely to be balanced across the treatment conditions. ITT analysis performed. Overall attrition 9.5\%. 


\begin{tabular}{lll}
\hline Bias & Support for judgement \\
\hline Selective reporting (reporting bias) & Low Risk & $\begin{array}{l}\text { Review authors judge that the published report } \\
\text { includes all expected outcomes, including those } \\
\text { that were pre-specified. }\end{array}$ \\
\hline Other bias & Low Risk & $\begin{array}{l}\text { Investigators report "the allocation of the } \\
\text { participants did not differ significantly in regard to } \\
\end{array}$ \\
& $\begin{array}{l}\text { demographic variables, diagnostic status or use of } \\
\text { medication because of ADHD" (page 43, col 2). } \\
\text { The study appeared to be free of other sources of } \\
\text { bias }\end{array}$ \\
\hline
\end{tabular}

\subsubsection{Lipman 2005}

\begin{tabular}{|c|c|}
\hline Methods & rallel randomised controlled trial. \\
\hline Participants & $\begin{array}{l}\text { Participants: single mothers of children aged } 3 \text { to } 9 \text { years who were recruited through advertisements in } \\
\text { community flyers at various locations. } \\
\text { Sex: all mothers. } \\
\text { Age of parents: mean } 32.4 \text { years (SD 6.7) intervention. mean } 32.3 \text { years (SD 6.1) control. } \\
\text { Unit of allocation: individual participant. } \\
\text { Number randomised: } 116 \text { (59 intervention; } 57 \text { control) } \\
\text { Number used in analysis: } 101 \text { (53 intervention; } 48 \text { control) at short-term follow-up; } 83 \text { (50 intervention; } \\
33 \text { control) at long-term follow-up. } \\
\text { Country \& setting: Canada; multi-site (number unclear); recruited from community settings; intervention } \\
\text { delivered in the community. } \\
\text { Inclusion criteria: single mothers; at least one child aged } 3 \text { to } 9 \text { years; able to speak English. } \\
\text { Exclusion criteria: acute psychiatric crisis (for example: psychotic or suicidal behaviour); threat of } \\
\text { violence. } \\
\text { Ethnicity: not reported; difference between groups significant at P<0.05 in terms of maternal education, } \\
\text { employment in last year, income, financial pressure and sources of financial support in past year. } \\
\text { Baseline characteristics: difference between groups significant at } P<0.05 \text { in terms of treated for 'nerves' } \\
\text { or nervous condition in last } 6 \text { months ( } 70 \% \text { in intervention; } 46 \% \text { in control). }\end{array}$ \\
\hline Interventions & $\begin{array}{l}\text { Two conditions: Social support and education (cognitive-behavioural parenting programme); wait-list } \\
\text { control. } \\
\text { Duration of intervention: } 10 \text { weeks. } \\
\text { Length of follow-up: } 4 \text { months; } 10 \text { months; } 17 \text { months. }\end{array}$ \\
\hline Outcomes & $\begin{array}{l}\text { Depressive symptoms (Center for Epidemiologic Studies Depression Scale). } \\
\text { Self-esteem (Rosenberg Self-Esteem Scale). }\end{array}$ \\
\hline Notes & $\begin{array}{l}\text { In this study, all outcomes were scored to reflect poor functioning (high score is worse). We therefore } \\
\text { input data as given in the paper without multiplying by - } 1 \text { to correct for scale direction. }\end{array}$ \\
\hline
\end{tabular}


Risk of bias table

\begin{tabular}{|c|c|c|}
\hline Bias & & Support for judgement \\
\hline $\begin{array}{l}\text { Random sequence generation (selection } \\
\text { bias) }\end{array}$ & Low Risk & $\begin{array}{l}\text { Trial investigators report "randomisation was done } \\
\text { in blocks of } 4 \text {, with numbers generated by a } \\
\text { random-numbers table and sealed in opaque } \\
\text { envelopes. Random sequence generation by a } \\
\text { random numbers table. }\end{array}$ \\
\hline
\end{tabular}

\begin{tabular}{lll}
\hline Allocation concealment (selection bias) $\quad$ Low Risk & Sealed opaque envelopes. \\
\hline
\end{tabular}

Blinding (performance bias and detection High Risk bias)

Participants
Review authors judged that it would not be possible to fully blind participants in this type of study, and found no indication of any specific additional measures taken to reduce the risk of bias that might result from differential behaviours by participants. The published report states it was not possible to conceal the group allocation from the participating mothers" (page 1452, col 2).

Blinding (performance bias and detection Unclear Risk bias)

Personnel Information reported insufficient for a judgement to be made. We requested clarification from the trial investigators, but no further information was available at the time this review was prepared.
Blinding (performance bias and detection High Risk bias)

Outcome assessors

Trial investigators report "assessment data were collected from all participants by interviewers working in pairs; at least one of the interviewers was blind to the mothers' group allocation" (page 1452, col 2). Review authors judged that not having both of the pair of interviewers blind to allocation is inadequate.

Incomplete outcome data (attrition bias) High Risk
Data for 6 of 59 (10\%) were missing from the intervention condition (reasons not given), and for 9 of $57(16 \%)$ from the control condition (reasons not given) at post-intervention. Review authors judged numbers of missing data appear approximately balanced. Although reasons for missing data were not given, the risk of bias was judged to be acceptable at this time point.

Overall attrition rate was $8 \%$. Data for 8 of 59 (14\%) were missing from the intervention condition (reasons not given), and for 16 of 57 (28\%) from the control condition (reasons not given) at 3 month follow-up. Overall attrition rate was 21\%. Data for 9 of $59(15 \%)$ were missing from the intervention 
condition (reasons not given), and for 24 of 57 (42\%) from the control condition (reasons not given) at 6 month follow-up. Overall attrition rate was $28.5 \%$. Review authors considered the numbers of missing data were not balanced across the treatment conditions at 3 month and 6 month follow-up.

\begin{tabular}{lll}
\hline Selective reporting (reporting bias) & Low Risk & $\begin{array}{l}\text { Review authors judge that the published report } \\
\text { includes all expected outcomes, including those } \\
\text { that were pre-specified. }\end{array}$ \\
\hline Other bias & Low Risk & $\begin{array}{l}\text { The study appeared to be free of other sources of } \\
\text { bias. }\end{array}$ \\
\hline
\end{tabular}

\subsubsection{Martin 2003}

\begin{tabular}{|c|c|}
\hline Methods & Parallel randomised controlled trial. \\
\hline Participants & $\begin{array}{l}\text { Participants: parents of children with the behavioural problems. } \\
\text { Sex: both mothers or fathers (no further information). } \\
\text { Age of parents: (for completers) mean } 37.25 \text { years (SD 5.26) intervention; } 39.57 \text { years (SD 3.91) } \\
\text { control; (range } 27 \text { to } 46 \text { years). } \\
\text { Unit of allocation: individual participant. } \\
\text { Number randomised: } 45 \text { (23 intervention; } 22 \text { control). } \\
\text { Number used in analysis: } 27 \text { (16 intervention; } 11 \text { control). } \\
\text { Country \& setting: Australia; single-site; recruited from community settings; intervention delivered in the } \\
\text { community. } \\
\text { Inclusion criteria: member of academic or general staff at University of Queensland; employed for at } \\
\text { least } 20 \text { hours/week; experiencing a significant level of distress juggling the demands of work and } \\
\text { home; having child aged } 2 \text { to } 9 \text { years; child having behavioural problems in the clinical range on the } \\
\text { Strengths \& Difficulties Questionnaire. } \\
\text { Exclusion criteria: not stated. } \\
\text { Ethnicity: not stated. } \\
\text { Baseline characteristics: marital status: } 25 \text { (81\%) married; } 1 \text { (3\%) divorced; } 4(13 \%) \text { separated; } \\
\text { education: } 27 \text { (87\%) tertiary education level; employment: } 21 \text { (68\%) general employment at University; } \\
10 \text { (32\%) academic employment at University. }\end{array}$ \\
\hline Interventions & $\begin{array}{l}\text { Two conditions: Work-Place Triple-P parent programme; wait-list control. } \\
\text { Duration of intervention: } 8 \text { weeks. } \\
\text { Length of follow up: 4-month follow-up for intervention condition only. }\end{array}$ \\
\hline Outcomes & $\begin{array}{l}\text { Depressive symptoms (Depression Anxiety Stress Scale). } \\
\text { Anxiety symptoms (Depression Anxiety Stress Scale)*. } \\
\text { Stress (Depression Anxiety Stress Scale)*. }\end{array}$ \\
\hline
\end{tabular}


Confidence (Problem Setting and Behaviour Checklist).

\section{Risk of bias table}

Bias

Random sequence generation (selection Unclear Risk bias)

\section{Support for judgement}

Information reported insufficient for a judgement to be made. We requested clarification from the trial investigators, but no further information was available at the time this review was prepared.

Allocation concealment (selection bias) Unclear Risk Information reported insufficient for a judgement to be made. We requested clarification from the trial investigators, but no further information was available at the time this review was prepared.

Blinding (performance bias and detection High Risk bias)

Participants to fully blind participants in this type of study, and found no indication of any specific additional
Review authors judged that it would not be possible measures taken to reduce the risk of bias that might result from differential behaviours by participants.

Information reported insufficient for a judgement to be made. We requested clarification from the trial investigators, but no further information was available at the time this review was prepared.

Information reported insufficient for a judgement to be made. We requested clarification from the trial investigators, but no further information was available at the time this review was prepared.

Data for $7 / 23$ (30\%) were missing from the intervention condition (reasons not given), and for $11 / 22$ (50\%) from the control condition (reasons not given). Review authors considered the numbers of a missing data were not balanced across the treatment conditions. Overall attrition rate was $40 \%$.

\begin{tabular}{lll}
\hline Selective reporting (reporting bias) & Low Risk & $\begin{array}{l}\text { Review authors judge that the published report } \\
\text { includes all expected outcomes, including those } \\
\text { that were pre-specified. }\end{array}$ \\
\hline Other bias & Low Risk & $\begin{array}{l}\text { The study appeared to be free of other sources of } \\
\text { bias. }\end{array}$ \\
\hline
\end{tabular}




\subsubsection{Matsumoto 2007}

\begin{tabular}{|c|c|}
\hline Methods & Parallel randomised controlled trial. \\
\hline Participants & $\begin{array}{l}\text { Participants: families with Japanese parents, where children had received support to learn and } \\
\text { maintain Japanese culture. } \\
\text { Sex: both mothers and fathers (no further information). } \\
\text { Age of parents: not stated. } \\
\text { Unit of allocation: individual family. } \\
\text { Number randomised: } 50 \text { ( } 25 \text { intervention, } 25 \text { control). } \\
\text { Number used in analysis: } 50 \text { ( } 25 \text { intervention, } 25 \text { control). } \\
\text { Country \& setting: Australia; single-site; recruited from community settings; intervention delivered in } \\
\text { the community. } \\
\text { Inclusion criteria: Japanese origin; resident in Gold Coast area of Queensland, Australia; with child } \\
\text { or children aged } 2 \text { to } 10 \text { years. } \\
\text { Exclusion criteria: not stated. } \\
\text { Ethnicity: mothers: } 48 \text { ( } 96 \%) \text { Japanese, } 2 \text { (4\%) Australian; fathers: } 15 \text { (30\%) Japanese, } 30 \text { (60\%) } \\
\text { Australian, } 5 \text { (10\%) other. } \\
\text { Baseline characteristics: marital status: } 45 \text { (90\%) married; } 2 \text { (4\%) divorced; education: } 27 \text { (54\%) } \\
\text { mothers had University education; } 33 \text { (66\%) fathers had University education; employment: } 40 \\
\text { (80\%) mothers unemployed; } 6 \text { (12\%) fathers unemployed; } 25 \text { (50\%) families receiving parenting } \\
\text { support; language at home Japanese only, } 17 \text { (34\%), English only, } 1 \text { (2\%), Japanese and English, } \\
32 \text { (64\%); children: } 27 \text { boys; } 23 \text { girls; children: mean } 4.9 \text { years. }\end{array}$ \\
\hline Interventions & $\begin{array}{l}\text { Two conditions: Group Triple-P Positive Parenting Program; wait-list control. } \\
\text { Duration of intervention: } 8 \text { weeks. } \\
\text { Length of follow up: } 3 \text { months. }\end{array}$ \\
\hline Outcomes & $\begin{array}{l}\text { Depressive symptoms (Depression Anxiety Stress Scale). } \\
\text { Anxiety symptoms (Depression Anxiety Stress Scale). } \\
\text { Stress (Depression Anxiety Stress Scale). } \\
\text { Confidence (Problem Setting and Behaviour Checklist). } \\
\text { Partner satisfaction (Relationship Quality Index). }\end{array}$ \\
\hline
\end{tabular}

\section{Risk of bias table}

Bias

Random sequence generation (selection Unclear Risk bias)

\section{Support for judgement}

Information reported insufficient for a judgement to be made, but information from trial investigator (email from K Sofronoff to CB on 21 Oct 2010) states "participants were allocated ID numbers and randomisation was done using the ID numbers".

Information reported insufficient for a judgement to be made. We requested clarification from the trial 
investigators, but no further information was available at the time this review was prepared.

Blinding (performance bias and detection High Risk bias)

Participants
Review authors judge that it would not be possible to fully blind participants in this type of study, and found no indication of any specific additional measures taken to reduce the risk of bias that might result from differential behaviours by participants.

Information reported insufficient for a judgement to be made, but information from trial investigator (email from K Sofronoff to CB on 20 Oct 2010) indicates that personnel were not blinded.

Information reported insufficient for a judgement to be made, but information from trial investigator (email from K Sofronoff to CB on 20 Oct 2010) indicates that outcome assessors were not blinded. There was no attrition from either condition and no missing outcome data.

Review authors judge that the published report includes all expected outcomes, including those that were pre-specified.

Other bias Low Risk
The study appeared to be free of other sources of bias. 


\subsubsection{Matsumoto 2010}

\begin{tabular}{|c|c|}
\hline Methods & Parallel randomised controlled trial. \\
\hline Participants & $\begin{array}{l}\text { Participants: Japanese families living in a Tokyo metropolitan area with the target child aged between } 2 \\
\text { and } 10 \text { years old. } \\
\text { Sex: both mothers and fathers (no further information). } \\
\text { Age of parents: not stated. } \\
\text { Unit of allocation: individual family. } \\
\text { Number randomised: } 54 \text { ( } 28 \text { intervention; } 26 \text { control). } \\
\text { Number used in analysis: } 51 \text { ( } 25 \text { intervention; } 26 \text { control). } \\
\text { Country \& setting: Japan; single site; recruited from community settings; intervention delivered in the } \\
\text { community. } \\
\text { Inclusion criteria: Japanese parents living in a Tokyo metropolitan area. } \\
\text { Exclusion criteria: parents who were suffering from major psychopathology were excluded; parents } \\
\text { whose child met clinical criteria for diagnosis of a pervasive developmental disorder were also } \\
\text { excluded. } \\
\text { Ethnicity: all Japanese. } \\
\text { Baseline characteristics: all the parents were married; education level of both parents was mainly } \\
\text { college or university; employment: all mothers were unemployed; all fathers were in full time } \\
\text { employment. }\end{array}$ \\
\hline Interventions & $\begin{array}{l}\text { Two conditions: Triple P-Positive Parenting Programme (PPP); wait-list control. } \\
\text { Duration of intervention: not stated; it is assumed that duration was } 8 \text { weeks as in the Matsumoto } 2007 \\
\text { study. } \\
\text { Length of follow-up: none stated. }\end{array}$ \\
\hline Outcomes & $\begin{array}{l}\text { Depressive symptoms (Depression Anxiety Stress Scale). } \\
\text { Anxiety symptoms (Depression Anxiety Stress Scale). } \\
\text { Stress (Depression Anxiety Stress Scale). } \\
\text { Confidence (Problem Setting and Behaviour Checklist). } \\
\text { Partner satisfaction (Relation Quality Index). }\end{array}$ \\
\hline & \\
\hline
\end{tabular}

\section{Risk of bias table}

\begin{tabular}{|c|c|c|}
\hline Bias & & Support for judgement \\
\hline $\begin{array}{l}\text { Random sequence generation (selection } \\
\text { bias) }\end{array}$ & Unclear Risk & $\begin{array}{l}\text { Trial investigators report that "the participants were } \\
54 \text { families who were randomly assigned to a } \\
\text { treatment group ( } 28 \text { families) or a wait-list group } \\
\text { ( } 26 \text { families). Information reported insufficient for a } \\
\text { judgment to be made. }\end{array}$ \\
\hline Allocation concealment (selection bias) & Unclear Risk & $\begin{array}{l}\text { Information reported insufficient for a judgment to } \\
\text { be made. }\end{array}$ \\
\hline Blinding (performance bias and detection & High Risk & Review authors judge that it would not be possible \\
\hline
\end{tabular}




\begin{tabular}{|c|c|c|}
\hline \multicolumn{2}{|l|}{ Bias } & \multirow{3}{*}{$\begin{array}{l}\text { Support for judgement } \\
\text { to fully blind participants in this type of study, and } \\
\text { found no indication of any specific additional } \\
\text { measures taken to reduce the risk of bias that } \\
\text { might result from differential behaviours by } \\
\text { participants. }\end{array}$} \\
\hline bias) & & \\
\hline Participants & & \\
\hline $\begin{array}{l}\text { Blinding (performance bias and detection } \\
\text { bias) }\end{array}$ & Unclear Risk & $\begin{array}{l}\text { Information reported insufficient for a judgment to } \\
\text { be made. }\end{array}$ \\
\hline \multicolumn{3}{|l|}{ Personnel } \\
\hline $\begin{array}{l}\text { Blinding (performance bias and detection } \\
\text { bias) }\end{array}$ & Unclear Risk & $\begin{array}{l}\text { Information reported insufficient for a judgment to } \\
\text { be made. }\end{array}$ \\
\hline Incomplete outcome data (attrition bias) & Low Risk & $\begin{array}{l}\text { Data for } 3 / 28 \text { (4\%) were missing from the } \\
\text { intervention condition (reasons not given), and } \\
\text { there were no missing data from the control } \\
\text { condition. Attrition rate was } 4 \% \text {. Review authors } \\
\text { considered the number of missing data were small, } \\
\text { and it is unlikely that this would introduce bias. }\end{array}$ \\
\hline Selective reporting (reporting bias) & Low Risk & $\begin{array}{l}\text { Review authors judge that the published report } \\
\text { includes all expected outcomes, including those } \\
\text { that were pre-specified. }\end{array}$ \\
\hline Other bias & Low Risk & $\begin{array}{l}\text { The study appeared to be free of other sources of } \\
\text { bias. }\end{array}$ \\
\hline
\end{tabular}

\subsubsection{McGillicuddy 2001}

\begin{tabular}{|c|c|}
\hline Methods & Parallel randomised controlled trial. \\
\hline Participants & $\begin{array}{l}\text { Participants: parents of substance abusing adolescents. } \\
\text { Sex: both mothers and fathers (no further information). } \\
\text { Age of parents: mean } 44.9 \text { years (SD 5.52) intervention; } 45.4 \text { (SD 4.41) control. } \\
\text { Unit of allocation: individual family. } \\
\text { Number randomised: } 22 \text { (14 intervention; } 8 \text { control). } \\
\text { Number used in analysis: } 22 \text { (14 intervention; } 8 \text { control). } \\
\text { Country \& setting: USA; single-site; recruited from community settings; intervention delivered in the } \\
\text { community. } \\
\text { Inclusion criteria: a parent/legal guardian of a child aged } 12-21 \text { who have lived in the same household } \\
\text { as the child at least } 30 \text { of the previous } 90 \text { days; parent reporting that the child was actively involved in } \\
\text { substance use over the previous six months, and not receiving any alcohol/drug treatment. } \\
\text { Exclusion criteria: parent's involvement in another form of treatment in relation to their child's substance } \\
\text { use; severe psychiatric disorder; involvement in alcohol/drug use; not living within commuting distance }\end{array}$ \\
\hline
\end{tabular}


of the research site.

Ethnicity: 86\% white intervention; 100\% white control.

Baseline characteristics: employed: 13 (93\%) intervention; 5 (63\%) control; years of education: mean

9.7 intervention; 9.1 (2.3) control married: 7 (50\%) intervention; 2 (25\%) control.

\begin{tabular}{|c|c|}
\hline Interventions & $\begin{array}{l}\text { Two condition: Cognitive-behavioural parenting programme; wait-list control. } \\
\text { Duration of intervention: } 8 \text { weeks. } \\
\text { Length of follow-up: none. }\end{array}$ \\
\hline Outcomes & $\begin{array}{l}\text { Depressive symptoms (Beck Depression Inventory). } \\
\text { Anxiety symptoms (Brief Symptom Inventory). } \\
\text { Anger (State-Trait Anger Expression Inventory). }\end{array}$ \\
\hline
\end{tabular}

\section{Risk of bias table}

Bias

Random sequence generation (selection Low Risk bias)

\section{Support for judgement}

Trial investigators report "individuals eligible for participation were told that their group would be assigned randomly to receive treatment immediately (i.e. skill training) or following an 8week delay (i.e. wait list)" (page 63). Information from trial investigator (e-mail from N McGillicuddy to $\mathrm{NH}$ on 25 Oct 2010) indicates that a random numbers table was used.

\section{Allocation concealment (selection bias) Low Risk}

Information reported insufficient for a judgement to be made, but information from trial investigator (email from B Irvine to $\mathrm{NH}$ on 22 Oct 2010) indicates that sufficient care was taken to ensure that therapists and research staff (including those who had pre-treatment contacts with participants) had no knowledge of whether a group's treatment would be immediate intervention or delayed treatment control. Random allocation was done separately and centrally for treatment condition and for treatment therapist.

Review authors judge that it would not be possible to fully blind participants in this type of study, and found no indication of any specific additional measures taken to reduce the risk of bias that might result from differential behaviours by participants.

Review authors judge that treatment and research 


\begin{tabular}{|c|c|c|}
\hline \multicolumn{2}{|l|}{ Bias } & \multirow{3}{*}{$\begin{array}{l}\text { Support for judgement } \\
\text { staff were kept blind to the cohort randomisation } \\
\text { scheme and to the pending treatment assignment } \\
\text { of the next cohort. }\end{array}$} \\
\hline bias) & & \\
\hline Personnel & & \\
\hline $\begin{array}{l}\text { Blinding (performance bias and detection } \\
\text { bias) }\end{array}$ & Low Risk & $\begin{array}{l}\text { Review authors judge that treatment and research } \\
\text { staff were kept blind to the cohort randomisation }\end{array}$ \\
\hline Outcome assessors & & $\begin{array}{l}\text { scheme and to the pending treatment assignment } \\
\text { of the next cohort. }\end{array}$ \\
\hline Incomplete outcome data (attrition bias) & Low Risk & No missing data reported. \\
\hline Selective reporting (reporting bias) & Low Risk & $\begin{array}{l}\text { Review authors judge that the published report } \\
\text { includes all expected outcomes, including those } \\
\text { that were pre-specified. }\end{array}$ \\
\hline Other bias & Low Risk & The study appeared free of other sources of bias. \\
\hline
\end{tabular}

\subsubsection{Morawska 2009}

\begin{tabular}{|c|c|}
\hline Methods & Parallel randomised controlled trial. \\
\hline Participants & $\begin{array}{l}\text { Participants: parents with child aged } 3 \text { to } 10 \text { years, reporting concerns about their child's behaviour or } \\
\text { their parenting. } \\
\text { Sex: } 68 \text { mothers; } 7 \text { fathers. } \\
\text { Age: mothers: mean } 39.28 \text { years (SD 5.50; range: } 27-54 \text { years); fathers: mean } 41.77 \text { years (SD } 6.01 ; \\
\text { range: } 35-56 \text { years). } \\
\text { Unit of allocation: individual participant. } \\
\text { Number randomised: } 75 \text { ( } 37 \text { intervention; } 38 \text { control). } \\
\text { Number used in analysis: } 60-70 \text { (29-33 intervention; } 31-37 \text { control). } \\
\text { Country \& setting: Australia; single-site; recruited from community settings; intervention delivered in the } \\
\text { community. } \\
\text { Inclusion criteria: family living within Brisbane metropolitan area; parents reporting concerns about their } \\
\text { child's behaviour or their parenting; child aged } 3 \text { to } 10 \text { years; child identified as 'gifted' by school or as } \\
\text { result of formal cognitive assessment. } \\
\text { Exclusion criteria: parents currently seeing a professional about their child's behaviour difficulties. } \\
\text { Ethnicity: Australian ( } 85.3 \%), \text { Asian (5.3\%); Maori (1.3\%), other (8\%). } \\
\text { Baseline characteristics: } 86.7 \% \text { children lived in their original family, } 8 \% \text { children lived in a single parent } \\
\text { family, and } 4 \% \text { lived in a step family; mean family size } 2.23 \text { children; education: } 77.3 \% \text { of mothers and } \\
65.3 \% \text { of fathers had a university degree; employment: } 60 \% \text { of mothers and } 86.7 \% \text { of fathers were } \\
\text { employed. }\end{array}$ \\
\hline Interventions & $\begin{array}{l}\text { Two conditions: Gifted and Talented Group Triple-P program; wait-list control. } \\
\text { Duration of intervention: } 9 \text { weeks. } \\
\text { Length of follow-up: } 6 \text { months for the intervention group only. }\end{array}$ \\
\hline Outcomes & Depressive symptoms (Depression Anxiety Stress Scale). \\
\hline
\end{tabular}


Anxiety symptoms (Depression Anxiety Stress Scale).

Stress (Depression Anxiety Stress Scale).

Confidence (Parenting Task Checklist).

Partner satisfaction (Relation Quality Index).

\section{Risk of bias table}

\begin{tabular}{lll}
\hline Bias & Support for judgement \\
\hline $\begin{array}{l}\text { Random sequence generation (selection } \\
\text { bias) }\end{array}$ & Low Risk & $\begin{array}{l}\text { Random sequence allocation by computer- } \\
\text { generated random numbers. }\end{array}$ \\
\hline Allocation concealment (selection bias) & High Risk & $\begin{array}{l}\text { Information from trial investigator (email from A } \\
\text { Morawska to CB on 26/10/10) states that a } \\
\text { research assistant not associated with the project } \\
\text { used a list to allocate participants, but there is no } \\
\text { indication that complete concealment of allocation } \\
\text { was attempted. }\end{array}$ \\
\hline
\end{tabular}

Blinding (performance bias and detection High Risk bias)

Participants
Review authors judge that it would not be possible to fully blind participants in this type of study, and found no indication of any specific additional measures taken to reduce the risk of bias that might result from differential behaviours by participants.

There is no indication either from the published report, or from the trial investigator that personal were blinded to the intervention (email from $\mathrm{A}$ Morawska to CB on 26/10/10).

The outcome assessment was self report by the parents so there were no judgements made by the assessors in relation to diagnostic status, however the parents were not blinded to the intervention.

On page 468 there was missing data for $8 / 37$ from the intervention group and $7 / 38$ from the control group. Data for $4 / 37(10.8 \%)$ were missing from the intervention condition, and for $1 / 38(2.6 \%)$ from the control condition. Reasons for the 5 missing given as: 1 moved area, 1 had a new baby; 1 had insufficient time to attend, 1 had received a recent diagnosis of LD for their child and 1 was undergoing chemotherapy (page 466, col 2). Further information from trial investigator provided 
some details about the pairwise exclusion of missing data in the report (email from A Morawska to $C B$ on $26 / 10 / 10$ ).

\begin{tabular}{|c|c|c|}
\hline Selective reporting (reporting bias) & Low Risk & $\begin{array}{l}\text { Review authors judge that the published report } \\
\text { includes all expected outcomes, including those } \\
\text { that were pre-specified. }\end{array}$ \\
\hline Other bias & Low Risk & $\begin{array}{l}\text { Investigators report "no between-group differences } \\
\text { on demographic variables were found on } \\
\text { preliminary analysis. There were also no significant } \\
\text { differences across the majority of outcome } \\
\text { variables. Pre-intervention scores were used as co- } \\
\text { variates in subsequent analyses to control for any } \\
\text { differences' (page } 466, \text { col } 2 \text { ). The study appeared } \\
\text { to be free of other sources of bias. }\end{array}$ \\
\hline
\end{tabular}

\subsubsection{Niccols 2009}

\begin{tabular}{|c|c|}
\hline Methods & Parallel randomised controlled trial. \\
\hline Participants & $\begin{array}{l}\text { Participants: mothers of child aged } 12 \text { to } 36 \text { months. } \\
\text { Sex: all mothers. } \\
\text { Age of parents: mean } 31.0 \text { years (SD } 5.7 \text {; range } 18 \text { to } 45 \text { years). } \\
\text { Unit of allocation: individual participant. } \\
\text { Number randomised: } 79 \text { ( } 49 \text { intervention; } 30 \text { control). } \\
\text { Number used in analysis: } 74 \text { (45 intervention; } 29 \text { control) at post-intervention; } 71 \text { (45 intervention; } 26 \\
\text { control) at short-term follow-up. } \\
\text { Country \& setting: Canada; single-site; recruited from community settings; intervention delivered in the } \\
\text { community. } \\
\text { Inclusion criteria: able to complete questionnaires in English; having a child of } 12 \text { to } 36 \text { months. } \\
\text { Exclusion criteria: previous attendance at any portion of CWTB programme. } \\
\text { Ethnicity: a range of ethnic backgrounds. } \\
\text { Baseline characteristics: mothers: married/cohabiting: } 82.3 \% \text {; education: } 84.8 \% \text { completed high school; } \\
\text { children: } 39.2 \% \text { children had no siblings; } 22 \% \text { scored above clinical cut-off on the child behaviour } \\
\text { problems questionnaire. The two study conditions did not differ significantly on pre-test maternal age, } \\
\text { education, socioeconomic status, marital status, infant age, infant gender, family size, family risk } \\
\text { factors, number of the services used, or child behaviour problems. }\end{array}$ \\
\hline Interventions & $\begin{array}{l}\text { Two conditions: COPEing with toddler behaviour (behavioural parenting programme); wait-list control. } \\
\text { Duration of intervention: } 8 \text { weeks. } \\
\text { Length of follow-up: } 1 \text { month. }\end{array}$ \\
\hline Outcomes & Depressive symptoms (Centre for Epidemiological Studies Depression Scale). \\
\hline
\end{tabular}




\section{Risk of bias table}

\begin{tabular}{|c|c|c|}
\hline Bias & & Support for judgement \\
\hline $\begin{array}{l}\text { Random sequence generation (selection } \\
\text { bias) }\end{array}$ & Low Risk & $\begin{array}{l}\text { Random sequence allocation by use of random } \\
\text { number tables. }\end{array}$ \\
\hline Allocation concealment (selection bias) & Low Risk & $\begin{array}{l}\text { Information reported insufficient for a judgement to } \\
\text { be made, but information from trial investigator } \\
\text { (email from A.Niccols to CB on } 20 \text { Oct 2010) } \\
\text { indicates that sealed opaque envelopes were used. }\end{array}$ \\
\hline $\begin{array}{l}\text { Blinding (performance bias and detection } \\
\text { bias) } \\
\text { Participants }\end{array}$ & High Risk & $\begin{array}{l}\text { Review authors judge that it would not be possible } \\
\text { to fully blind participants in this type of study, and } \\
\text { found no indication of any specific additional } \\
\text { measures taken to reduce the risk of bias that } \\
\text { might result from differential behaviours by } \\
\text { participants. }\end{array}$ \\
\hline
\end{tabular}

Blinding (performance bias and detection Low Risk bias)

Personnel Information reported insufficient for a judgement to be made, but information from trial investigator (email from a.Niccols to CB on 20 Oct 2010) indicates that personnel were blind.
Blinding (performance bias and detection Low Risk bias)

Outcome assessors

Incomplete outcome data (attrition bias) Low Risk

Investigators report that outcome assessors were blind to allocation status of participants and the method of randomisation (page 619, col 2).

Data for $4 / 49(8 \%)$ were missing from the intervention condition (failed to reach), and for $1 / 30$ (3\%) from the control condition (failed to reach) at post-intervention. Data for 4/49 (8\%) were missing from the intervention condition (failed to reach), and for $4 / 30$ (13\%) from the control condition (failed to reach) at post-intervention at follow-up. Overall attrition rate was $8 \%$. Review authors considered the numbers of and reasons for missing data reasonably likely to be balanced across the treatment conditions.

\begin{tabular}{lll} 
Selective reporting (reporting bias) & Low Risk & $\begin{array}{l}\text { Review authors judge that the published report } \\
\text { includes all expected outcomes, including those } \\
\text { that were pre-specified. }\end{array}$ \\
\hline Other bias & Low Risk & $\begin{array}{l}\text { Investigators report the two groups did not differ } \\
\text { significantly on baseline characteristics. The study } \\
\text { appeared to be free of other sources of bias. }\end{array}$
\end{tabular}




\subsubsection{Nicholson 2002}

\begin{tabular}{|c|c|}
\hline Methods & Parallel randomised controlled trial. \\
\hline Participants & $\begin{array}{l}\text { Participants: parents of low socioeconomic status who made excessive use of verbal and corporal } \\
\text { punishment. } \\
\text { Sex (main carer): } 25 \text { mothers or grandmothers (23 mothers; } 2 \text { grandmothers), } 1 \text { father. } \\
\text { Age of parents: mean } 31 \text { years (SD 11.97). } \\
\text { Unit of allocation: individual participant. } \\
\text { Number randomised: } 26 \text { (13 intervention; } 13 \text { control). } \\
\text { Number used in analysis: } 26 \text { (13 intervention; } 13 \text { control). } \\
\text { Country \& setting: USA; single-site; recruited from community settings; intervention delivered in the } \\
\text { community. } \\
\text { Inclusion criteria: families with one child between } 1 \text { and } 5 \text { years who reported frequent use of verbal or } \\
\text { corporal punishment. } \\
\text { Exclusion criteria: families with children who had psychiatric diagnoses or who were receiving special } \\
\text { education services in school. } \\
\text { Ethnicity: } 14 \text { (54\%) African American; } 6 \text { (23\%) Hispanic; } 4 \text { (15\%) white; } 2 \text { (8\%) other. } \\
\text { Baseline characteristics: education: } 7 \text { (27\%) not completed high school, } 8 \text { (30\%) high school graduate, } \\
11 \text { (42\%) completed some post-high-school education; } 16 \text { (62\%) single, } 10 \text { (38\%) married. }\end{array}$ \\
\hline Interventions & $\begin{array}{l}\text { Two conditions: STAR parenting programme (cognitive-behavioural parenting programme); wait-list } \\
\text { control. } \\
\text { Duration of intervention: } 10 \text { weeks. } \\
\text { Length of follow-up: } 1 \text { month. }\end{array}$ \\
\hline Outcomes & Stress (Parenting Stress Index). \\
\hline Notes & \\
\hline
\end{tabular}

\section{Risk of bias table}

Bias

Random sequence generation (selection Low Risk bias)

\section{Support for judgement}

Information from trial investigator (email from RA Fox to NH on 26 Oct 2010) indicates that random allocation was by computer-generated random numbers.

Allocation concealment (selection bias) High Risk
Information from trial investigator (email from RA Fox to $\mathrm{NH}$ on 26 Oct 2010) indicates that the allocation sequence was known to one of the six individuals who also delivered some of the treatment services. This raises the possibility of bias.

Review authors judge that it would not be possible to fully blind participants in this type of study, and found no indication of any specific additional 
measures taken to reduce the risk of bias that might result from differential behaviours by participants.

Blinding (performance bias and detection Unclear Risk bias)

Personnel
Information from trial investigator (email from RA Fox to $\mathrm{NH}$ on 26 Oct 2010) indicates that five of the six trial personnel/outcome assessors were blinded, but one was not.

Information from trial investigator (email from RA Fox to $\mathrm{NH}$ on 26 Oct 2010) indicates that five of the six trial personnel/outcome assessors were blinded, but one was not.

Analyses were performed on all randomised participants. No missing data reported and "missed sessions were rescheduled to ensure that each parent consistently received the entire psychoeducational parenting program" (page 366).

Selective reporting (reporting bias) Low Risk

Review authors judge that the published report includes all expected outcomes, including those that were pre-specified.

Other bias

Low Risk
The study appears to be free of other sources of bias.

\subsubsection{Nixon 1993}

\begin{tabular}{|c|c|}
\hline Methods & Parallel randomised controlled trial. \\
\hline Participants & $\begin{array}{l}\text { Participants: volunteer parents of children with severe developmental disabilities attending special } \\
\text { schools. } \\
\text { Sex: both mothers and fathers (no further information). } \\
\text { Age of participants: not stated. } \\
\text { Unit of allocation: individual family. } \\
\text { Number randomised: } 58 \text { (breakdown by group not given). } \\
\text { Number used in analysis: } 34 \text { (18 intervention, } 16 \text { control). } \\
\text { Country \& setting: USA; single-site; recruited from community settings; intervention delivered in the } \\
\text { community. } \\
\text { Inclusion criteria: parents of children with severe developmental disabilities attending special schools. } \\
\text { Exclusion criteria: not stated. } \\
\text { Ethnicity: not stated. } \\
\text { Baseline characteristics: not stated. }\end{array}$ \\
\hline
\end{tabular}




\begin{tabular}{ll}
\hline Interventions & \begin{tabular}{l} 
Two conditions: Cognitive-behavioural parenting programme; wait-list control. \\
Duration of intervention: 5 weeks. \\
\cline { 2 - 2 } \\
Length of follow-up: none.
\end{tabular} \\
\hline Outcomes & $\begin{array}{l}\text { Depressive symptoms (Beck Depression Inventory). } \\
\text { Guilt (Situational Guilt Scale). }\end{array}$ \\
\hline Notes & \\
\hline
\end{tabular}

\section{Risk of bias table}

Bias

Random sequence generation (selection Unclear Risk bias)

\section{Support for judgement}

Trial investigators report "fifty-eight subjects were randomly assigned to treatment or waiting list control groups" (page 668). Information reported insufficient for a judgement to be made. We requested clarification from the trial investigators, but no further information was available at the time this review was prepared.

Allocation concealment (selection bias) Unclear Risk Information reported insufficient for a judgement to be made. We requested clarification from the trial investigators, but no further information was available at the time this review was prepared.

Blinding (performance bias and detection High Risk bias)

Participants
Trial investigators report "at the time of the initial phone call, parents were randomly assigned to treatment and control groups and were informed of their assignment" (page 667). Review authors judge that it would not be possible to fully blind participants in this type of study, and found no indication of any specific additional measures taken to reduce the risk of bias that might result from differential behaviours by participants.

Information reported insufficient for a judgement to be made. We requested clarification from the trial investigators, but no further information was available at the time this review was prepared.

Information reported insufficient for a judgement to be made. We requested clarification from the trial investigators, but no further information was available at the time this review was prepared.

8 of $29(26 \%)$ in the treatment group and 10 of 29 (34\%) in the control group did not complete posttests, and a further 3 of $29(10 \%)$ in the treatment 
group and 3 of $29(10 \%)$ in the control group were excluded because the independence of husband's and wife's scores could not be demonstrated. Review authors considered that numbers of and reasons for missing data were approximately balanced between conditions.

Attrition $41 \%$.

\begin{tabular}{lll} 
Selective reporting (reporting bias) & Low Risk & $\begin{array}{l}\text { Review authors judge that the published report } \\
\text { includes all expected outcomes, including those } \\
\text { that were pre-specified. }\end{array}$ \\
\hline Other bias & Low Risk & $\begin{array}{l}\text { The study appeared to be free of other sources of } \\
\text { bias. }\end{array}$
\end{tabular}

\subsubsection{Odom 1996}

\begin{tabular}{|c|c|}
\hline Methods & Parallel randomised controlled trial. \\
\hline Participants & $\begin{array}{l}\text { Participants: volunteer parents of children with ADHD. } \\
\text { Sex: all mothers. } \\
\text { Age of parents: mean } 32.7 \text { years (range=24 to 47). } \\
\text { Unit of allocation: individual participant. } \\
\text { Number randomised: } 25 \text { (13 intervention; } 12 \text { control). } \\
\text { Number used in analysis: } 20 \text { (10 intervention; } 10 \text { control). } \\
\text { Country \& setting: USA; recruited from community settings; intervention delivered in the community. } \\
\text { Inclusion criteria: low socioeconomic status mothers who had a male child between the ages of } 5 \text { and } 11 \\
\text { with ADHD, who had been taking methylphenidate, and who met noncompliant behavioural criteria. } \\
\text { Exclusion criteria: not stated. } \\
\text { Ethnicity: } 75 \% \text { African American. } \\
\text { Baseline characteristics: } 85 \% \text { biological mothers; } 70 \% \text { single mothers; average educational level was } 12 \\
\text { years (range 8-15). }\end{array}$ \\
\hline Interventions & $\begin{array}{l}\text { Two conditions: Educational parent training (behavioural parenting programme); wait-list control. } \\
\text { Duration of intervention: } 5 \text { weeks. } \\
\text { Length of follow-up: none. }\end{array}$ \\
\hline Outcomes & Confidence (Parenting Sense of Competence Scale). \\
\hline Notes & \\
\hline
\end{tabular}

\section{Risk of bias table}

Bias Support for judgement

Random sequence generation (selection Low Risk Information from trial investigator (email from S 
Bias

bias)

Allocation concealment (selection bias) Low Risk

\section{Support for judgement}

Odom to $\mathrm{NH}$ on 26 Oct 2010) indicates that random allocation was by drawing lots from a hat.

Information from trial investigator (email from $\mathrm{S}$ Odom to $\mathrm{NH}$ on 26 Oct 2010) indicates that names of participants were placed on pieces of paper which here then drawn from a hat "first one to the control group and then one to the intervention group until there were 15 in each". Review authors consider this process is unlikely to have introduced a risk of bias.
Blinding (performance bias and detection High Risk bias)

Participants

Review authors judge that it would not be possible to fully blind participants in this type of study, and found no indication of any specific additional measures taken to reduce the risk of bias that might result from differential behaviours by participants.

Blinding (performance bias and detection Low Risk bias)

Personnel

Blinding (performance bias and detection Low Risk bias)

Outcome assessors

Incomplete outcome data (attrition bias) Low Risk

Information from trial investigator (email from S Odom to NH on 26 Oct 2010) indicates that "all involved parties were blinded to allocation status".

Information from trial investigator (email from S Odom to NH on 26 Oct 2010) indicates that "all involved parties were blinded to allocation status".

At 5 weeks, 3/13 (23\%) were missing from intervention group (due to non-compliance or inability to participate in the educational sessions) and 2/12 (17\%) were missing from control group (one due to her husband disagreeing that their male child receive the stimulant medication; reason not given for the other). Review authors judge that missing outcome data were balanced in numbers across conditions, even though the reasons for the missing data differed slightly.

Review authors judge that the published report includes all expected outcomes, including those that were pre-specified.

Other bias Low Risk
The study appears to be free of other sources of bias. 


\subsubsection{Patterson 2002}

\begin{tabular}{|c|c|}
\hline Methods & Parallel randomised controlled trial. \\
\hline Participants & $\begin{array}{l}\text { Participants: parents of children aged 2-8 years registered at three GP practices in Oxford. } \\
\text { Sex: both mothers or fathers (no further information). } \\
\text { Age of parents: not stated. } \\
\text { Unit of allocation: individual participant. } \\
\text { Number randomised: } 116 \text { ( } 60 \text { intervention; } 56 \text { control). } \\
\text { Number used in analysis: } 95-96 \text { (45-46 intervention; } 50 \text { control). } \\
\text { Country \& setting: UK; multi-site (number not stated); recruited from primary care settings; } \\
\text { intervention delivered in primary care. } \\
\text { Inclusion criteria: scoring above } 100 \text { on the Eyberg Child Behaviour Inventory (ECBI). } \\
\text { Exclusion criteria: not stated. } \\
\text { Ethnicity: } 91.4 \% \text { white, } 4.8 \% \text { Asian, } 2.9 \% \text { mixed race, } 1 \% \text { Black. } \\
\text { Baseline characteristics: } 14.7 \% \text { single parents. } 13.3 \% \text { social class I, 39.0\% social class II, } 22.9 \% \\
\text { social class III N, } 13.3 \% \text { social class III M, } 5.7 \% \text { social class IV, } 5.7 \% \text { social class V. }\end{array}$ \\
\hline Interventions & $\begin{array}{l}\text { Two conditions: Webster-Stratton parenting program; no-treatment control. } \\
\text { Duration of Intervention: } 10 \text { weeks. } \\
\text { Length of follow-up: } 3 \text { months; } 6 \text { months. }\end{array}$ \\
\hline Outcomes & $\begin{array}{l}\text { Depressive symptoms (General Health Questionnaire). } \\
\text { Anxiety symptoms (General Health Questionnaire). } \\
\text { Stress (Parenting Stress Index-total). } \\
\text { Self-esteem (Rosenberg Self-Esteem Scale). }\end{array}$ \\
\hline Notes & Includes follow up data from Stewart-Brown 2004. \\
\hline
\end{tabular}

\section{Risk of bias table}

Bias

Random sequence generation (selection Low Risk bias)

Allocation concealment (selection bias) Low Risk

\section{Support for judgement}

Trial investigators report that randomisation was "by tossing a coin in the presence of an independent witness, to treatment or control" (page 473). Review authors judge that the allocation sequence was adequately generated.

Information reported insufficient for a judgement to be made, but information from trial investigator (email from J Patterson to NH on 23 Oct 2010) indicates that central allocation was used involving a third party not otherwise involved in the trial.

Review authors judge that it would not be possible to fully blind participants in this type of study, and found no indication of any specific additional measures taken to reduce the risk of bias that might result from differential behaviours by participants. 


\begin{tabular}{|c|c|c|}
\hline Bias & & Support for judgement \\
\hline $\begin{array}{l}\text { Blinding (performance bias and detection } \\
\text { bias) }\end{array}$ & Low Risk & $\begin{array}{l}\text { Information reported insufficient for a judgement to be } \\
\text { made, but information from trial investigator (email from J }\end{array}$ \\
\hline Personnel & & $\begin{array}{l}\text { Patterson to NH on } 23 \text { Oct 2010) indicates that personnel } \\
\text { involved in data handling were blind to allocation until } \\
\text { after all quantitative data had been collected. }\end{array}$ \\
\hline $\begin{array}{l}\text { Blinding (performance bias and detection } \\
\text { bias) }\end{array}$ & Low Risk & $\begin{array}{l}\text { Information reported insufficient for a judgement to be } \\
\text { made, but information from trial investigator (email from J }\end{array}$ \\
\hline Outcome assessors & & $\begin{array}{l}\text { Patterson to } \mathrm{NH} \text { on } 23 \text { Oct 2010) indicates that outcome } \\
\text { assessors were blinded during collection and analysis of } \\
\text { quantitative data. }\end{array}$ \\
\hline Incomplete outcome data (attrition bias) & Low Risk & $\begin{array}{l}\text { At } 6 \text { months follow up, } 4 / 60 \text { (7\%) were missing from } \\
\text { intervention group and 4/56 (7\%) were missing from the } \\
\text { control group. At } 12 \text { months follow up, 16/60 (27\%) were } \\
\text { missing from intervention group and 13/56 (23\%) were } \\
\text { missing from the control group. Reasons for missing data } \\
\text { not broken down by condition but included increased work } \\
\text { commitment, moving away from the area, depression, } \\
\text { other life stress, and holiday falling at start of group } \\
\text { sessions. Trial investigators report no difference in the } \\
\text { proportion of attenders or non-attenders returning } \\
\text { questionnaires at follow up. Review authors judge the } \\
\text { numbers of missing data were balanced between } \\
\text { conditions. }\end{array}$ \\
\hline Selective reporting (reporting bias) & Low Risk & $\begin{array}{l}\text { Review authors judge that the published report includes } \\
\text { all expected outcomes, including those that were pre- } \\
\text { specified. }\end{array}$ \\
\hline Other bias & Low Risk & The study appears to be free of other sources of bias. \\
\hline
\end{tabular}

\subsubsection{Pisterman 1992a}

Methods

Participants

\section{Parallel randomised controlled trial.}

Participants: parents of preschoolers aged 3-6 years who were clinically diagnosed with ADHD.

Sex: both mothers and fathers (no further details); assessment was performed only on the target parents (88 mothers, 3 fathers).

Age of parents: not stated.

Unit of allocation: individual family.

Number randomised: 91 (46 in Study 1: 23 intervention; 23 control; 45 in Study 2: 23 intervention; 22 control).

Number used in analysis: 91 (46 intervention; 45 control) at post- 
intervention; 46 (23 intervention; 23 control) at follow-up.

Country \& setting: Canada; single-site; recruited from community and outpatient settings: intervention delivered in an outpatient clinic.

Inclusion criteria: parents of preschoolers aged 3-6 years, who were

clinically diagnosed with ADHD.

Exclusion criteria: not stated.

Ethnicity: not stated.

Baseline characteristics: not stated.

Interventions

Outcomes
Two conditions: Behavioural parenting programme; wait-list control.

Duration of intervention: 12 weeks.

Length of follow-up: 3 months.

Depressive symptoms (Parenting Stress Index).

Stress (Parenting Stress Index).

Confidence (Parenting Stress Index).

Partner satisfaction (Parenting Stress Index).

\section{Notes}

\section{Risk of bias table}

Bias

Random sequence generation (selection Unclear Risk bias)

\section{Support for judgement}

Investigators report that "families of eligible children were randomly assigned to an immediate treatment group (experimental group) or a delayed treatment group (control group)" (pages 46-47). Information reported insufficient for a judgement to be made. We requested clarification from the trial investigators, but no further information was available at the time this review was prepared.

Information reported insufficient for a judgement to be made. We requested clarification from the trial investigators, but no further information was available at the time this review was prepared.

Review authors judged that it would not be possible to fully blind participants in this type of study, and found no indication of any specific additional measures taken to reduce the risk of bias that might result from differential behaviours by participants.

Information reported insufficient for a judgement to be made. We requested clarification from the trial investigators, but no further information was 
available at the time this review was prepared.

Blinding (performance bias and detection Unclear Risk bias)

Outcome assessors
Information reported insufficient for a judgement to be made. We requested clarification from the trial investigators, but no further information was available at the time this review was prepared.

Trial investigators report an overall dropout rate of 8\% in Study 1 and 21\% in Study 2 with no significant difference between conditions. Breakdown by condition not provided. Information reported insufficient for a judgement to be made. We requested clarification from the trial investigators, but no further information was available at the time this review was prepared.

Review authors judge that the published report includes all expected outcomes, including those that were pre-specified.

Other bias

Low Risk
Study appeared free of other form of bias although, as the investigators noted, "the present study did not include an attention control group...therefore, it is possible that reported improvements were a function of demand characteristics" (page 55).

\subsubsection{Pisterman 1992b}

\begin{tabular}{|c|c|}
\hline Methods & Parallel randomised controlled trial. \\
\hline Participants & $\begin{array}{l}\text { Participants: parents of preschoolers aged 3-6 years who were clinically diagnosed with ADHD. } \\
\text { Sex: both mothers and fathers (no further information). } \\
\text { Age of participants: not stated. } \\
\text { Unit of allocation: individual family. } \\
\text { Number randomised: } 57 \text { ( } 28 \text { intervention; } 29 \text { control). } \\
\text { Number used in analysis: number available for analysis n=45 ( } 23 \text { intervention; } 22 \text { control).* } \\
\text { Country \& setting: Canada; single-site; recruited from community and outpatient settings; intervention } \\
\text { delivered in an outpatient clinic. } \\
\text { Inclusion criteria: parents of pre-schoolers aged 3-6 years who were clinically diagnosed with ADHD. } \\
\text { Exclusion criteria: not stated. } \\
\text { Ethnicity: not stated. } \\
\text { Baseline characteristics: not stated. }\end{array}$ \\
\hline Interventions & $\begin{array}{l}\text { Two conditions: Behavioural parenting programme; wait-list control. } \\
\text { Duration of intervention: } 12 \text { weeks. } \\
\text { Length of follow-up: } 3 \text { months. }\end{array}$ \\
\hline
\end{tabular}




\begin{tabular}{ll}
\hline Outcomes & Stress (Parenting Stress Index). \\
& Confidence (Parenting Stress Index). \\
\hline Notes & *Insufficient data to calculate effect sizes. Clarification was requested from the trial investigators but no \\
& further information was available at the time this review was prepared. \\
\hline
\end{tabular}

\section{Risk of bias table}

Bias

\section{Support for judgement}

Random sequence generation (selection Unclear Risk bias)

Information reported insufficient for a judgement to be made. We requested clarification from the trial investigators, but no further information was available at the time this review was prepared.

Allocation concealment (selection bias) Unclear Risk Information reported insufficient for a judgement to be made. We requested clarification from the trial investigators, but no further information was available at the time this review was prepared.

Blinding (performance bias and detection High Risk bias)

Participants
Review authors judge that it would not be possible to fully blind participants in this type of study, and found no indication of any specific additional measures taken to reduce the risk of bias that might result from differential behaviours by participants.

Information reported insufficient for a judgement to be made. We requested clarification from the trial investigators, but no further information was available at the time this review was prepared.

Information reported insufficient for a judgement to be made. We requested clarification from the trial investigators, but no further information was available at the time this review was prepared.

Data missing for 5 of $28(18 \%)$ in the treatment condition and for 7 of 29 (24\%) in the control condition due to participants dropping out of the study. The overall dropout rate was $21.1 \%$. Review authors judge the numbers of missing data and reasons for missing data were balanced between conditions.

Review authors judge that the published report includes all expected outcomes, including those that were pre-specified. 
bias.

\subsubsection{Schultz 1993}

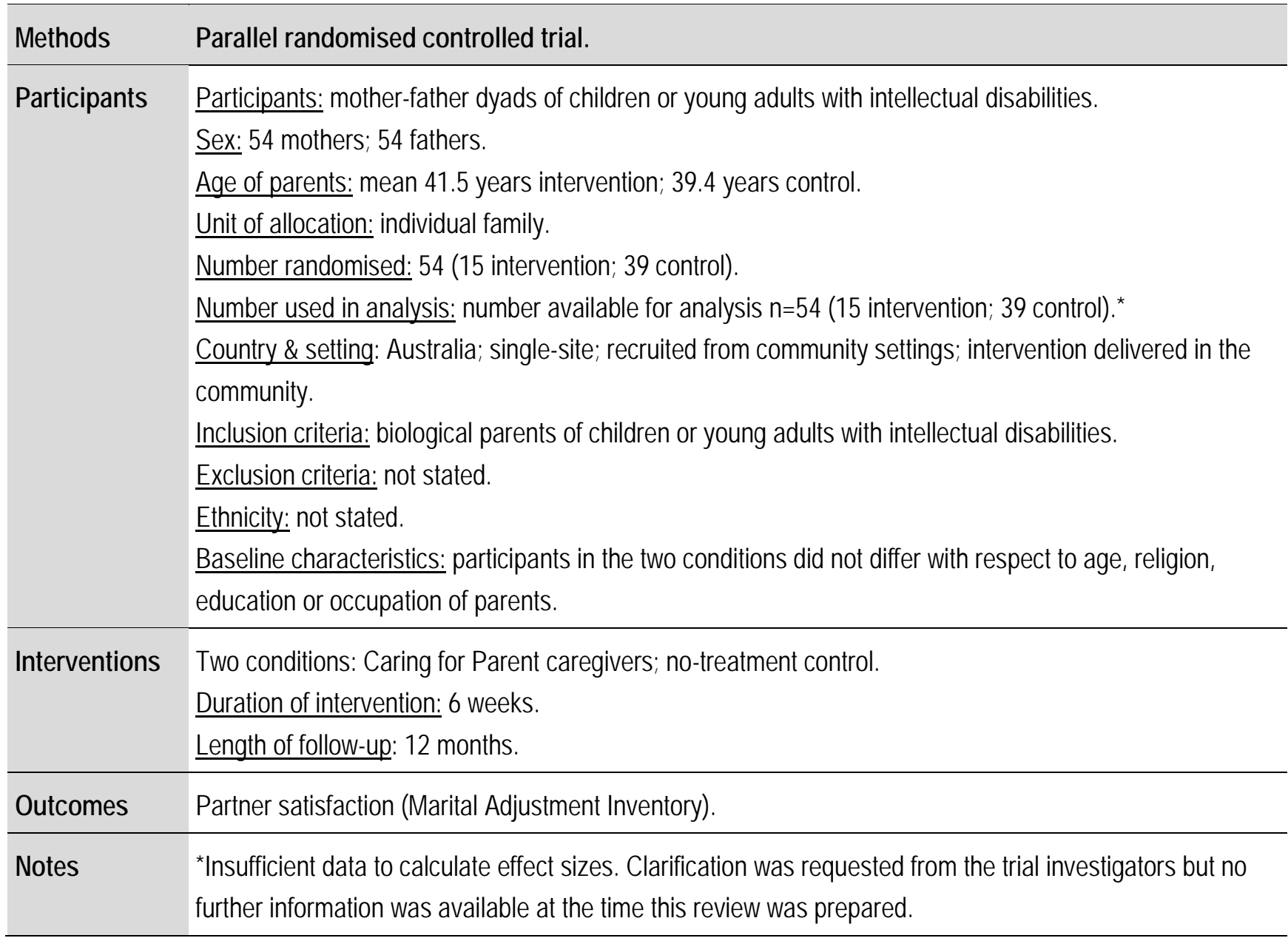

\section{Risk of bias table}

\begin{tabular}{lll}
\hline Bias & Support for judgement \\
\hline $\begin{array}{l}\text { Random sequence generation (selection } \\
\text { bias) }\end{array}$ & Unclear Risk & $\begin{array}{l}\text { Information reported insufficient for a judgement to } \\
\text { be made. We requested clarification from the trial } \\
\text { investigators, but no further information was } \\
\text { available at the time this review was prepared. }\end{array}$ \\
\hline $\begin{array}{lll}\text { Allocation concealment (selection bias) } & \text { Unclear Risk } & \text { Information reported insufficient for a judgement to } \\
& \text { be made. We requested clarification from the trial } \\
\text { investigators, but no further information was } \\
\text { available at the time this review was prepared. } \\
\begin{array}{l}\text { bias) } \\
\text { Participants }\end{array}\end{array}$ & $\begin{array}{l}\text { Review authors judge that it would not be possible } \\
\text { to fully blind participants in this type of study, and } \\
\text { found no indication of any specific additional }\end{array}$ \\
\hline
\end{tabular}




\begin{tabular}{|c|c|c|}
\hline Bias & & Support for judgement \\
\hline & & $\begin{array}{l}\text { measures taken to reduce the risk of bias that might } \\
\text { result from differential behaviours by participants. }\end{array}$ \\
\hline $\begin{array}{l}\text { Blinding (performance bias and detection } \\
\text { bias) } \\
\text { Personnel }\end{array}$ & Unclear Risk & $\begin{array}{l}\text { Information reported insufficient for a judgement to } \\
\text { be made. We requested clarification from the trial } \\
\text { investigators, but no further information was } \\
\text { available at the time this review was prepared. }\end{array}$ \\
\hline $\begin{array}{l}\text { Blinding (performance bias and detection } \\
\text { bias) } \\
\text { Outcome assessors }\end{array}$ & Unclear Risk & $\begin{array}{l}\text { Information reported insufficient for a judgement to } \\
\text { be made. We requested clarification from the trial } \\
\text { investigators, but no further information was } \\
\text { available at the time this review was prepared. }\end{array}$ \\
\hline Incomplete outcome data (attrition bias) & Unclear Risk & $\begin{array}{l}\text { Information reported insufficient for a judgement to } \\
\text { be made. We requested clarification from the trial } \\
\text { investigators, but no further information was } \\
\text { available at the time this review was prepared. }\end{array}$ \\
\hline Selective reporting (reporting bias) & Low Risk & $\begin{array}{l}\text { Review authors judge that the published report } \\
\text { includes all expected outcomes, including those that } \\
\text { were pre-specified. }\end{array}$ \\
\hline Other bias & Low Risk & $\begin{array}{l}\text { The study appears to be free of other sources of } \\
\text { bias. }\end{array}$ \\
\hline
\end{tabular}

\subsubsection{Sirbu 1978}

\begin{tabular}{|c|c|}
\hline Methods & Parallel randomised controlled trial. \\
\hline Participants & $\begin{array}{l}\text { Participants: volunteer mothers of preschool children. } \\
\text { Sex: all mothers. } \\
\text { Age of parents: not stated. } \\
\text { Unit of allocation: individual participant. } \\
\text { Number randomised: } 60 \text { (number randomised to the four conditions; no further information). } \\
\text { Number used in analysis: number available in analysis not stated*. } \\
\text { Country \& setting: USA; single-site; recruited from community settings; intervention delivered in the } \\
\text { community. } \\
\text { Inclusion criteria: mothers of preschool children. } \\
\text { Exclusion criteria: not stated. } \\
\text { Ethnicity: all Caucasian. } \\
\text { Baseline characteristics: no significant differences between the four conditions in the mother's level of } \\
\text { education, occupation, number of children, or significant medical problems. }\end{array}$ \\
\hline Interventions & $\begin{array}{l}\text { Four conditions: three behavioural parenting training groups (course \& programmed text; course alone; } \\
\text { programmed text alone); attention-placebo control. } \\
\text { Duration of intervention: } 5 \text { weeks. }\end{array}$ \\
\hline
\end{tabular}


Length of follow-up: none.

\begin{tabular}{ll}
\hline Outcomes & Stress (Parent Stress Satisfaction Questionnaire) \\
\hline Notes & *Insufficient data to calculate effect sizes. Clarification was requested from the trial investigators but no \\
& further information was available at the time this review was prepared.
\end{tabular}

\section{Risk of bias table}

Bias Authors' judgement Support for judgement

Random sequence generation (selection Unclear Risk bias)

Trial investigators report that mothers "were randomly assigned to one of four treatment groups" (page164). Information reported insufficient for a judgement to be made. We requested clarification from the trial investigators, but no further information was available at the time this review was prepared.

Allocation concealment (selection bias) Unclear Risk Information reported insufficient for a judgement to be made. We requested clarification from the trial investigators, but no further information was available at the time this review was prepared.

Blinding (performance bias and detection High Risk bias)

Participants
Trial investigators report that "instructions were given to each groups about the course, and in the case of Groups 2 and 4, not to look at a copy of Becker's book" (page 165), thus attempting to ensure participants were unaware of the type of intervention they were receiving. However, there is no information whether the instructions given were followed.

Information reported insufficient for a judgement to be made. We requested clarification from the trial investigators, but no further information was available at the time this review was prepared.

Information reported insufficient for a judgement to be made. We requested clarification from the trial investigators, but no further information was available at the time this review was prepared.

Information reported insufficient for a judgement to be made. We requested clarification from the trial investigators, but no further information was available at the time this review was prepared.

Review authors judge that the published report includes all expected outcomes, including those that 
were pre-specified.

Other bias

Low Risk

The study appears to be free of other sources of bias.

\subsubsection{Spaccerelli 1992}

\begin{tabular}{|c|c|}
\hline Methods & arallel randomised controlled trial. \\
\hline Participants & $\begin{array}{l}\text { Participants: volunteer parents concerned about their child behaviour problem. } \\
\text { Sex: (completers) } 47 \text { mothers; } 6 \text { fathers. } \\
\text { Age of parents: mean } 35.5 \text { years. } \\
\text { Unit of allocation: individual participant. } \\
\text { Number randomised: } 126 \text { (number randomised to the three conditions; no further information; } 81 \\
\text { participated in the pre-test assessment). } \\
\text { Number used in analysis: number available for analysis n=53 (no further information)*. } \\
\text { Country \& setting: USA; single-site; recruited from community settings; intervention delivered in the } \\
\text { community. } \\
\text { Inclusion criteria: parents concerned about their child behaviour problems. } \\
\text { Exclusion criteria: not stated. } \\
\text { Ethnicity: (81participants): } 35 \text { white; } 28 \text { Hispanic; } 14 \text { Black; } 4 \text { others. } \\
\text { Baseline characteristics: }(81 \text { participants): } 27 \text { single/divorced, } 47 \text { married, } 7 \text { missing data; } 21 \text { high } \\
\text { school, } 32 \text { some college education, } 27 \text { graduates, } 1 \text { missing data. }\end{array}$ \\
\hline Interventions & $\begin{array}{l}\text { Three conditions: behavioral (Webster-Stratton) parent programme \& problem-solving skills training; } \\
\text { behavioral parent training and discussion; wait-list control. } \\
\text { Duration of intervention: } 16 \text { hours ( } 10 \text { hours behavioral parent programme \& } 6 \text { hours problem solving } \\
\text { skills training). } \\
\text { Length of follow-up: } 4 \text { to } 5 \text { months. }\end{array}$ \\
\hline Outcomes & Stress (Parenting Stress Index). ${ }^{*}$ \\
\hline Notes & $\begin{array}{l}\text { *Insufficient data to calculate effect sizes. Clarification was requested from the trial investigators but no } \\
\text { further information was available at the time this review was prepared. }\end{array}$ \\
\hline
\end{tabular}

\section{Risk of bias table}

Bias

Random sequence generation (selection Unclear Risk bias)

\section{Authors' judgement Support for judgement}

Trial investigators report that "the 126 parents expressing interest in participating were randomly assigned" (page 5). Information reported insufficient for a judgement to be made. We requested clarification from the trial investigators, but no further information was available at the time this review was 
prepared.

Allocation concealment (selection bias) Unclear Risk
Information reported insufficient for a judgement to be made. We requested clarification from the trial investigators, but no further information was available at the time this review was prepared.

Review authors judge that it would not be possible to fully blind participants in this type of study, and found no indication of any specific additional measures taken to reduce the risk of bias that might result from differential behaviours by participants.

Information reported insufficient for a judgement to be made. We requested clarification from the trial investigators, but no further information was available at the time this review was prepared.

Information reported insufficient for a judgement to be made. We requested clarification from the trial investigators, but no further information was available at the time this review was prepared.

Attrition rates and numbers of missing data not provided, although effects of attrition were analysed by the trial investigators who found rates of attrition not significantly different between the three experimental groups. In terms of demographics, there was a significant main effect for attrition status on parent education, indicating that less educated parents were more likely to drop out. We requested clarification from the trial investigators, but no further information was available at the time this review was prepared.

\begin{tabular}{lll}
\hline Selective reporting (reporting bias) & Low Risk & $\begin{array}{l}\text { Review authors judge that the published report } \\
\text { includes all expected outcomes, including those that } \\
\text { were pre-specified. }\end{array}$ \\
\hline Other bias & High Risk & $\begin{array}{l}\text { Two measures in the study were newly devised } \\
\text { (page 15). This raises the possibility of bias. }\end{array}$ \\
\hline
\end{tabular}




\subsubsection{Taylor 1998}

\begin{tabular}{|c|c|}
\hline Methods & Parallel randomised controlled trial. \\
\hline Participants & $\begin{array}{l}\text { Participants: families of } 3 \text { to } 8 \text { year old children with conduct problems. } \\
\text { Sex: } 107 \text { mothers, } 70 \text { fathers. } \\
\text { Age of parents: mean } 33 \text { years, mothers; mean } 37 \text { years, fathers. } \\
\text { Unit of allocation: individual family. } \\
\text { Number randomised: } 110^{\star} \text { ( } 46 \text { 'Parents and Children Series' parent programme; } 46 \text { Eclectic programme; } \\
18 \text { wait-list control). } \\
\text { Number used in analysis: } n=32 \text { ( } 15 \text { intervention; } 17 \text { control) for 'depressive' symptoms; } n=17 \text { ( } 7 \\
\text { intervention; } 10 \text { control) for 'partner satisfaction'. } \\
\text { Country \& setting: USA; single-site; recruited from community settings; intervention delivered in an } \\
\text { outpatient clinic. } \\
\text { Inclusion criteria: families who contacted the Regional Family Centre for assistance related to conduct } \\
\text { problems of } 3 \text { to } 8 \text { year old children, or to difficulties in parenting a child of this age. } \\
\text { Exclusion criteria: not stated. } \\
\text { Ethnicity: not stated. } \\
\text { Baseline characteristics: (108 participants): } 69 \text { married or common-law couples, } 38 \text { single mothers; } 1 \\
\text { father. }\end{array}$ \\
\hline Interventions & $\begin{array}{l}\text { Three conditions: 'Parents and Children Series' (Webster-Stratton) parent programme; Eclectic } \\
\text { Programme (delivered individually); wait-list control. } \\
\text { Duration of intervention: } 11 \text { to } 14 \text { weeks. } \\
\text { Length of follow-up: } 4 \text { months. }\end{array}$ \\
\hline Outcomes & $\begin{array}{l}\text { Depressive symptoms (Back Depression Inventory). } \\
\text { Partner satisfaction (Dyadic Adjustment Scale). }\end{array}$ \\
\hline Notes & $\begin{array}{l}\text { *Some families served initially as wait list controls and then were randomly assigned to either of the two } \\
\text { interventions, based on need. We analysed results from } 15 \text { families who received the PACS intervention } \\
\text { and were directly compared to the } 17 \text { families who were assigned to the wait list control group and did } \\
\text { not receive the intervention at any stage (p. } 288 \text { 'Assignment to treatment conditions; and Table 1) }\end{array}$ \\
\hline
\end{tabular}

Risk of bias table

\begin{tabular}{lll}
\hline Bias & $\begin{array}{l}\text { Authors' } \\
\text { judgement }\end{array}$ & Support for judgement \\
\hline $\begin{array}{l}\text { Random sequence generation } \\
\text { (selection bias) }\end{array}$ & Unclear Risk & $\begin{array}{l}\text { Trial investigators report "families who were potential wait-list } \\
\text { candidates were randomly assigned to either of the two } \\
\text { treatments or to the wait-list control group, while families who } \\
\text { had no possibility of wait-list were randomly assigned } \\
\text { between the two treatments" (page 228). Information } \\
\text { reported insufficient for a judgement to be made. We } \\
\text { requested clarification from the trial investigators, but no } \\
\text { further information was available at the time this review was } \\
\text { prepared. }\end{array}$ \\
\hline
\end{tabular}




\begin{tabular}{|c|c|c|}
\hline Bias & $\begin{array}{l}\text { Authors' } \\
\text { judgement }\end{array}$ & Support for judgement \\
\hline $\begin{array}{l}\text { Allocation concealment (selection } \\
\text { bias) }\end{array}$ & Unclear Risk & $\begin{array}{l}\text { Information reported insufficient for a judgement to be made. } \\
\text { We requested clarification from the trial investigators, but no } \\
\text { further information was available at the time this review was } \\
\text { prepared. }\end{array}$ \\
\hline $\begin{array}{l}\text { Blinding (performance bias and } \\
\text { detection bias) } \\
\text { Participants }\end{array}$ & High Risk & $\begin{array}{l}\text { Review authors judge that it would not be possible to fully } \\
\text { blind participants in this type of study, and found no indication } \\
\text { of any specific additional measures taken to reduce the risk } \\
\text { of bias that might result from differential behaviours by } \\
\text { participants. }\end{array}$ \\
\hline $\begin{array}{l}\text { Blinding (performance bias and } \\
\text { detection bias) } \\
\text { Personnel }\end{array}$ & High Risk & $\begin{array}{l}\text { Review authors judge that the design of the study means } \\
\text { personnel would be aware which participants had been } \\
\text { assigned to the immediate intervention conditions. }\end{array}$ \\
\hline $\begin{array}{l}\text { Blinding (performance bias and } \\
\text { detection bias) } \\
\text { Outcome assessors }\end{array}$ & High Risk & $\begin{array}{l}\text { Trial investigators report" research assistants who collected } \\
\text { post-test assessment measures were not informed of } \\
\text { treatment assignment, although on occasion families } \\
\text { revealed which treatment they received" (page 230). Review } \\
\text { authors considered that the blinding of the outcome } \\
\text { assessors was therefore compromised. }\end{array}$ \\
\hline $\begin{array}{l}\text { Incomplete outcome data (attrition } \\
\text { bias) }\end{array}$ & Unclear Risk & $\begin{array}{l}\text { Intention to treat analyses were performed for those families } \\
\text { who attended at least one treatment session. Two } \\
\text { participants of } 46 \text { (4\%) in the PACS group and } 2 \text { of } 46 \text { (4\%) in } \\
\text { the eclectic treatment group attended no treatment sessions. } \\
\text { Investigators report that "the design of the study did not allow } \\
\text { for all comparison to be done simultaneously in a single } \\
\text { analysis because the wait-list control group was comparable } \\
\text { only to a sub-sample of each of the two treatments. For this } \\
\text { reason, each hypothesis was tested separately, using only } \\
\text { those participants relevant to hypothesis" (page } 231 \text { ). } \\
\text { Information reported insufficient for a judgement to be made. } \\
\text { We requested clarification from the trial investigators, but no } \\
\text { further information was available at the time this review was } \\
\text { prepared. }\end{array}$ \\
\hline Selective reporting (reporting bias) & Low Risk & $\begin{array}{l}\text { Review authors judge that the published report includes all } \\
\text { expected outcomes, including those that were pre-specified. }\end{array}$ \\
\hline Other bias & Low Risk & The study appears to be free of other sources of bias. \\
\hline
\end{tabular}




\subsubsection{Treacy 2005}

\begin{tabular}{|c|c|}
\hline Methods & Parallel randomised controlled trial. \\
\hline Participants & $\begin{array}{l}\text { Participants: parents of children diagnosed with DSM-IV ADHD recruited through an ADHD research } \\
\text { clinic and the paediatric outpatient department of a local hospital. } \\
\text { Sex: } 40 \text { mothers (including } 3 \text { step mothers and } 1 \text { foster mothers) ; } 23 \text { fathers (including } 2 \text { step fathers). } \\
\text { Age of parents: mean } 36.3 \text { years mothers (SD 5.5; range } 28-49 \text { years); mean } 38.8 \text { years (SD 6.6; range; } \\
26-53) . \\
\text { Unit of allocation: individual family. } \\
\text { Number randomised: } 42 \text { families and } 63 \text { participants (breakdown by group not given). } \\
\text { Number used in analysis: } 21-32 \text { (12-16 intervention; } 9-17 \text { control). } \\
\text { Country \& setting: New Zealand; single-site; recruited from outpatient and research clinic settings; } \\
\text { intervention delivered in an outpatient clinic. } \\
\text { Inclusion criteria: families with at least one child diagnosed with DSM-IV ADHD. } \\
\text { Exclusion criteria: severe relationship difficulties between parents who both wished to participate; major } \\
\text { psychiatric disorder. } \\
\text { Ethnicity: not stated. } \\
\text { Baseline characteristics: mean family socioeconomic status on SES scale, 4.2 (SD 1.7); } 88.1 \% \text { of } \\
\text { children prescribed methylphenidate for their ADHD; } 27 / 42 \text { (64.3\%) families were 2-parent families; } \\
47.4 \% \text { children had delinquent behaviour problems; } 56.1 \% \text { children had aggressive behaviour problems; } \\
37 \text { (88.1\%) boys. }\end{array}$ \\
\hline Interventions & $\begin{array}{l}\text { Two conditions: Parent stress management parenting program; wait-list control. } \\
\text { Duration of intervention: } 9 \text { weeks. } \\
\text { Length of follow-up: no follow-up. }\end{array}$ \\
\hline Outcomes & $\begin{array}{l}\text { Depressive symptoms (Beck Depression Inventory). } \\
\text { Stress (Parenting Stress Index). } \\
\text { Partner satisfaction (Locke-Wallace Marital Adjustment test). }\end{array}$ \\
\hline & \\
\hline
\end{tabular}

Risk of bias table

\begin{tabular}{lll}
\hline Bias & Support for judgement \\
\hline $\begin{array}{l}\text { Random sequence generation (selection } \\
\text { bias) }\end{array}$ & Unclear Risk & $\begin{array}{l}\text { Information reported insufficient for a judgement to } \\
\text { be made. We requested clarification from the trial } \\
\text { investigators, but no further information was } \\
\text { available at the time this review was prepared. }\end{array}$ \\
\hline Allocation concealment (selection bias) & Unclear Risk & $\begin{array}{l}\text { Information reported insufficient for a judgement to } \\
\text { be made. We requested clarification from the trial } \\
\text { investigators, but no further information was } \\
\text { available at the time this review was prepared. }\end{array}$ \\
& &
\end{tabular}

Blinding (performance bias and detection High Risk bias)
Review authors judge that it would not be possible to fully blind participants in this type of study, and 


\begin{tabular}{|c|c|c|}
\hline Bias & & Support for judgement \\
\hline Participants & & $\begin{array}{l}\text { found no indication of any specific additional } \\
\text { measures taken to reduce the risk of bias that might } \\
\text { result from differential behaviours by participants. }\end{array}$ \\
\hline $\begin{array}{l}\text { Blinding (performance bias and detection } \\
\text { bias) } \\
\text { Personnel }\end{array}$ & Unclear Risk & $\begin{array}{l}\text { Information reported insufficient for a judgement to } \\
\text { be made. We requested clarification from the trial } \\
\text { investigators, but no further information was } \\
\text { available at the time this review was prepared. }\end{array}$ \\
\hline $\begin{array}{l}\text { Blinding (performance bias and detection } \\
\text { bias) } \\
\text { Outcome assessors }\end{array}$ & Unclear Risk & $\begin{array}{l}\text { Information reported insufficient for a judgement to } \\
\text { be made. We requested clarification from the trial } \\
\text { investigators, but no further information was } \\
\text { available at the time this review was prepared. }\end{array}$ \\
\hline Incomplete outcome data (attrition bias) & Low Risk & $\begin{array}{l}\text { After randomisation, but prior to the beginning of } \\
\text { treatment, } 3 \text { withdrew from the control group and } 1 \\
\text { withdrew for the intervention group. One parent } \\
\text { completed only } 7 \text { out of } 9 \text { treatment sessions. } \\
\text { Investigators report overall } 98.4 \% \text { completion of } \\
\text { outcome measures at baseline and } 84.1 \% \text { at post- } \\
\text { treatment, but with no breakdown by treatment } \\
\text { condition. Review authors considered the numbers } \\
\text { of and reasons for missing data reasonably likely to } \\
\text { be balanced across the treatment conditions. }\end{array}$ \\
\hline Selective reporting (reporting bias) & Low Risk & $\begin{array}{l}\text { Review authors judge that the published report } \\
\text { includes all expected outcomes, including those that } \\
\text { were pre-specified. }\end{array}$ \\
\hline Other bias & Low Risk & $\begin{array}{l}\text { The study appeared to be free of other sources of } \\
\text { bias. }\end{array}$ \\
\hline
\end{tabular}

\subsubsection{Turner 2007}

\begin{tabular}{|c|c|}
\hline Methods & Parallel randomised controlled trial. \\
\hline \multirow[t]{8}{*}{ Participants } & Participants: indigenous families of the children 1 to 13 years of age presenting to four South-East \\
\hline & Queensland Community Health sites. \\
\hline & Sex: 45 mothers; 6 fathers. \\
\hline & Age of parents: mean 34.52 years (SD 10.54), intervention; mean 30.87 years (SD 7.65), control. \\
\hline & Unit of allocation: individual participant. \\
\hline & Number randomised: 51 (26 intervention; 25 control). \\
\hline & Number used in analysis: 38 (20 intervention; 18 control). \\
\hline & Country \& setting: Australia; multi-site $(n=4)$; recruited from community settings; intervention delivered \\
\hline
\end{tabular}


Inclusion criteria: indigenous families with target child aged between 1 and 13 years; primary caregiver had concerns about their child's behaviour or their own parenting skills.

Exclusion criteria: developmental delay; major physical difficulty; severe chronic illness; developmental disorder (for example: autism); current medication or contact with another professional for behavioural problems.

Ethnicity: all indigenous ethnicity.

Baseline characteristics: mean 2.5 children per family; 11 (22\%) in full time employment; 32 (63\%) unemployed; 35 (68\%) two-parent family; target child: 33 (65\%) boys; 34 (67.3\%) mothers, $3(6.1 \%)$ fathers, 9 (16.3\%) grandmothers, $3(6.1 \%)$ aunts and $2(4.0 \%)$ guardians.

Interventions Two conditions: 'Group Triple P' parent programme; wait-list control.

Duration of intervention: 8 weeks.

Length of follow-up: 6 months (intervention group only).

Outcomes Depressive symptoms (Depression Anxiety Stress Scale).

Stress (Depression Anxiety Stress Scale).

Notes

\section{Risk of bias table}

\begin{tabular}{|c|c|c|}
\hline Bias & & Support for judgement \\
\hline $\begin{array}{l}\text { Random sequence generation (selection } \\
\text { bias) }\end{array}$ & Low Risk & $\begin{array}{l}\text { Information reported insufficient for a judgement to } \\
\text { be made, but information from trial investigator } \\
\text { (email from K Turner to CB on } 28 \text { Oct 2010) states } \\
\text { "the research officer used a computer program for } \\
\text { random number generation for each site". }\end{array}$ \\
\hline Allocation concealment (selection bias) & Low Risk & $\begin{array}{l}\text { Information reported insufficient for a judgement to } \\
\text { be made. Information from trial investigators (email } \\
\text { from K Turner to CB on } 28 \text { Oct 2010) states that } \\
\text { "there were sealed envelopes". }\end{array}$ \\
\hline
\end{tabular}
bias)

Participants
Blinding (performance bias and detection High Risk

Review authors judged that it would not be possible to fully blind participants in this type of study, and found no indication of any specific additional measures taken to reduce the risk of bias that might result from differential behaviours by participants. Investigators report that trial personnel were blind to allocation status of participants.

bias)

Personnel

Blinding (performance bias and detection Low Risk bias) Investigators report that outcome assessors were blind to allocation status of participants.

Outcome assessors 
condition (2 new baby; 1 decided not to participate; 1 illness in family; 1 illness; 1 too busy with work), and for $7 / 25$ (28\%) from the control condition (3 unknown; 1 death in family; 1 illness in family; 1 premature baby; 1 family crisis). Overall attrition was $25.5 \%$ at post-intervention. Review authors considered the numbers of and reasons for missing data reasonably likely to be balanced across the treatment conditions.

\begin{tabular}{|c|c|c|}
\hline Selective reporting (reporting bias) & High Risk & $\begin{array}{l}\text { Investigators do not report on the anxiety scale of } \\
\text { the DASS. A } 42 \text { item questionnaire was chosen but } \\
\text { this was reduced to only } 14 \text { items(depression and } \\
\text { stress) on the request of the local medical board to } \\
\text { reduce the assessment burden on parents. }\end{array}$ \\
\hline Other bias & Low Risk & $\begin{array}{l}\text { The study appears to be free of other sources of } \\
\text { bias. Investigators report "there were no significant } \\
\text { differences between those who completed post- } \\
\text { assessment and those who did not on any } \\
\text { demographic or outcome measure at pre-test" (page } \\
433, \text { col 1). }\end{array}$ \\
\hline
\end{tabular}

\subsubsection{1van den Hoofdakker 2007}

\begin{tabular}{|c|c|}
\hline Methods & Parallel randomised controlled trial. \\
\hline Participants & $\begin{array}{l}\text { Participants: parents of children between } 4 \text { and } 12 \text { years of age with ADHD who were referred to an } \\
\text { outpatient mental health clinic by their GP. } \\
\text { Sex: both mothers and fathers (no further information). } \\
\text { Age of parents: not stated. } \\
\text { Unit of allocation: individual family. } \\
\text { Number randomised: } 96 \text { ( } 48 \text { intervention; } 48 \text { control). } \\
\text { Number used in analysis: } 94 \text { (47 intervention; } 47 \text { control). } \\
\text { Country \& setting: Netherlands; single-site; recruited from an outpatient setting; intervention delivered in } \\
\text { an outpatient clinic. } \\
\text { Inclusion criteria: DSM-IV criteria for ADHD; IQ > 80; child aged between } 4 \text { and } 12 \text { years; both parents (if } \\
\text { present) willing to participate in the parent program. } \\
\text { Exclusion criteria: families who had already received intensive behavioural parent training the year } \\
\text { before; problems with the child/or family that required immediate intervention (for example: crisis in the } \\
\text { family). } \\
\text { Ethnicity: } 94.7 \% \text { white, } 2.1 \% \text { African, } 2.1 \% \text { Asian, } 1.1 \% \text { unknown. } \\
\text { Baseline characteristics: marital status: } 73 \text { (77.7\%) two biological parents; } 10 \text { (10.6\%) single parent; } 11 \\
\text { (11.7\%) one biological, one step-parent; no statistically significant differences in child or family }\end{array}$ \\
\hline
\end{tabular}


characteristics between two conditions, with the exception of tics (significantly higher frequency in the control group).

Interventions Two conditions: Behavioural parent programme plus treatment as usual; treatment as usual control. Duration of intervention: 12 sessions over 5-month period.

Length of follow-up: 6 months (intervention group only).

Outcomes Stress (Parenting Stress Index).

Notes

\section{Risk of bias table}

\begin{tabular}{|c|c|c|}
\hline Bias & & Support for judgement \\
\hline $\begin{array}{l}\text { Random sequence generation (selection } \\
\text { bias) }\end{array}$ & Low Risk & $\begin{array}{l}\text { Information reported insufficient for a judgement to } \\
\text { be made, but information from trial investigator } \\
\text { (email from B van den Hoofdakker to CB on } 24 \text { Nov) } \\
\text { states "the randomisation sequence of family id- } \\
\text { numbers was computer generated". }\end{array}$ \\
\hline Allocation concealment (selection bias) & Low Risk & $\begin{array}{l}\text { Information reported insufficient for a judgement to } \\
\text { be made, but information from trial investigator } \\
\text { (email from B van den Hoofdakker to CB on } 24 \text { Nov) } \\
\text { states "''an external researcher generated the } \\
\text { allocation sequence and preserved the list of } \\
\text { randomised family id-numbers. This researcher did } \\
\text { not work in the outpatient mental health clinic where } \\
\text { the study was conducted, was not involved in } \\
\text { assessment or treatment, and did not determine } \\
\text { eligibility for the study or entry of patients". }\end{array}$ \\
\hline
\end{tabular}

Blinding (performance bias and detection High Risk bias)

Participants
Review authors judge that it would not be possible to fully blind participants in this type of study, and found no indication of any specific additional measures taken to reduce the risk of bias that might result from differential behaviours by participants.

Information reported insufficient for a judgement to be made. We requested clarification from the trial investigators, but no further information was available at the time this review was prepared.

Information reported insufficient for a judgement to be made. We requested clarification from the trial investigators, but no further information was available at the time this review was prepared.
Blinding (performance bias and detection Unclear Risk bias)

Outcome assessors
Data for $1 / 48(2 \%)$ missing from the intervention 
condition (urgent problems requiring immediate treatment), and for $1 / 48$ (2\%) from the control condition. Overall attrition was $2 \%$ at postintervention. Investigators report that an additional 5 discontinued (for personal reasons or because immediate treatment was required) with the missing endpoint data replaced with LOCF values. Review authors considered the numbers of and reasons for missing data reasonably likely to be balanced across the treatment conditions.

Selective reporting (reporting bias) Low Risk Review authors judge that the published report includes all expected outcomes, including those that were pre-specified.

\section{Other bias}

Low Risk

Investigators report:

a) there were no statistically significant differences between conditions at baseline on demographic or outcome measures with the exception of the presence of tics (a comorbid condition) which had a significantly higher frequency in the control group $(P=.006)$.

b) investigators carried out repeated-measures ANOVAs to examine for interaction effects between time, treatment, and medication status and parenting stress. Results $\left(F_{(2,91)}=0.010, P=.990\right)$ indicate that medication status at study entry did not affect treatment effects.

c) there were no statistical differences (Chi ${ }^{2}$ tests) in the proportion of children who were taking medication between the two conditions at baseline and at post-treatment.

The study appeared free of other sources of bias. 


\subsubsection{Wang 2005}

\begin{tabular}{|c|c|}
\hline Methods & Parallel randomised controlled trial. \\
\hline Participants & $\begin{array}{l}\text { Participants: families of children with autism. } \\
\text { Sex: both mothers and fathers (no further information). } \\
\text { Age of parents: biological mothers: mean } 33.4 \text { years intervention; } 33.5 \text { years control; biological fathers: } \\
\text { mean } 34.5 \text { years intervention; } 34.9 \text { years control. } \\
\text { Unit of allocation: individual family. } \\
\text { Number randomised: } 34 \text { ( } 17 \text { intervention; } 17 \text { control). } \\
\text { Number used in analysis: } 27 \text { Parental stress ( } 15 \text { intervention; } 12 \text { control) from Wang } 2005 \text { (thesis data). } \\
\text { Country \& setting: China; single-site; recruited from community settings; intervention delivered in the } \\
\text { community. } \\
\text { Inclusion criteria: child <10 years old; formal diagnosis of autism by professionals or agencies not } \\
\text { affiliated with the project. } \\
\text { Exclusion criteria: not stated. } \\
\text { Ethnicity: all Chinese. } \\
\text { Baseline characteristics: } 33 \% \text { parents had no previous training on autism; the other } 66 \% \text { had received } \\
\text { some form of training from an education service centre that included behaviour management, language } \\
\text { instruction and applied behaviour analysis. }\end{array}$ \\
\hline Interventions & $\begin{array}{l}\text { Two conditions: Interactive skills of parents programme (behavioural parenting programme); wait-list } \\
\text { control. } \\
\text { Duration of intervention: } 4 \text { weeks. } \\
\text { Duration of trial: } 5 \text { weeks. } \\
\text { Length of follow-up: none. }\end{array}$ \\
\hline Outcomes & Stress (Parenting Stress Index). \\
\hline Notes & \\
\hline
\end{tabular}

Risk of bias table

Bias

Random sequence generation (selection Low Risk bias)

\section{Support for judgement}

Information from trial investigator (e-mail from $P$ Wang to CB on 31 Oct 2010) states "randomisation was completed via coin flipping".

No allocation concealment was attempted.

Allocation concealment (selection bias) High Risk Review authors judge that it would not be possible

Blinding (performance bias and detection High Risk bias)

Participants to fully blind participants in this type of study, and found no indication of any specific additional measures taken to reduce the risk of bias that might result from differential behaviours by participants.

Principal investigator delivered the training and also assessed the outcomes. 


\section{Personnel}

Blinding (performance bias and detection High Risk bias)

Outcome assessors
Principal investigator delivered the training and also assessed the outcomes.

\section{Incomplete outcome data (attrition bias) Low Risk}

There was missing outcome data: "after commencement of the study, two families dropped out of the training group and five dropped out of the control group, leaving 15 families remaining in the training group and 12 in the control group. One of the families in the training group, after completing the entire training program, dropped out during the posttest data collection phase because of a prescheduled family vacation.' (p.97, col 2)."

\begin{tabular}{lll}
\hline Selective reporting (reporting bias) & Low Risk & $\begin{array}{l}\text { Review authors judge that the published report } \\
\text { includes all expected outcomes, including those that } \\
\text { were pre-specified. }\end{array}$ \\
\hline Other bias & Low Risk & $\begin{array}{l}\text { The study appears to be free of other sources of } \\
\text { bias. }\end{array}$ \\
\hline
\end{tabular}

\subsubsection{Webster Stratton 1988}

\begin{tabular}{|c|c|}
\hline Methods & led trial. \\
\hline Participants & $\begin{array}{l}\text { Participants: professionally referred parents of } 3 \text { to } 8 \text { year old children with conduct disorder. } \\
\text { Sex: } 114 \text { mothers; } 80 \text { fathers. } \\
\text { Age of parents: mean } 32.8 \text { years, mothers; mean } 35.1 \text { years, fathers. } \\
\text { Unit of allocation: individual family. } \\
\text { Number randomised: } 114 \text { ( } 29 \text { GDVM; } 28 \text { IVM; } 28 \mathrm{GD} ; 29 \text { control). } \\
\text { Number used in analysis: } 54 \text { ( } 27 \text { intervention; } 27 \text { control). } \\
\text { Country \& setting: USA; single-site; recruited from community settings; intervention delivered in the } \\
\text { community. } \\
\text { Inclusion criteria: parents of the child aged } 3 \text { to } 8 \text { years; parents had rated their child as having a clinically } \\
\text { significant number of behavioural problems according to the Eyberg Child Behaviour Inventory; primary } \\
\text { referral problem of child misconduct that had been occurring for more than } 6 \text { months. } \\
\text { Exclusion criteria: parents of children with debilitating physical impairment, intellectual deficit, or history of } \\
\text { psychosis. } \\
\text { Ethnicity: not stated. } \\
\text { Baseline characteristics: } 69.3 \% \text { married, } 30.7 \% \text { single. }\end{array}$ \\
\hline Inte & $\begin{array}{l}\text { Four conditions: Group discussion videotape modelling (Webster-Stratton parenting programme) } \\
\text { (GDVM); Individual videotape modelling (IVM); Group discussion (GD); wait-list control. }\end{array}$ \\
\hline
\end{tabular}


Duration of intervention: 10-12 weeks.

Length of follow-up: none.

Outcomes

Stress (Parenting Stress Index).

Notes

We used data from the GDVM arm only compared with wait-list control to avoid double counting of participants in the control group.

\section{Risk of bias table}

Bias

Random sequence generation (selection Low Risk bias)

\section{Support for judgement}

Trial investigators report that parents "were randomly assigned to one of four groups" (Abstract). Information from trial investigator (e-mail from $\mathrm{C}$ Webster-Stratton to NH on 22 Oct 2010) indicates that randomisation was achieved by the drawing of lots (i.e. names on folded pieces of paper drawn blindly from a hat).
"Once subjects were accepted for entry, a randomly selected sealed envelope was opened that designated each family's parent training condition" (page 560). Review authors judged that allocation was probably adequately concealed.

Blinding (performance bias and detection High Risk bias)

Participants

Blinding (performance bias and detection Low Risk bias)

Personnel

Blinding (performance bias and detection Low Risk bias)

Outcome assessors
Review authors judge that it would not be possible to fully blind participants in this type of study, and found no indication of any specific additional measures taken to reduce the risk of bias that might result from differential behaviours by participants.

Information reported insufficient for a judgement to be made. Information from trial investigator (e-mail from C Webster-Stratton to NH on 22 Oct 2010) indicates that all personnel were blind to allocation status.

"Home observations were made by eight extensively trained observers who were blind to the hypothesis and the group membership of the subjects" (page 560). Independent assessors were blinded.

For mothers, 2/29 (7\%) missing from GDVN condition, 1/28 (4\%) missing from IVM condition, 4/28 (14\%) missing from GD condition and 2/29 (7\%) missing from control condition. Review authors judge that missing outcome data approximately balanced in numbers across conditions. 


\begin{tabular}{lll} 
Selective reporting (reporting bias) & Low Risk & $\begin{array}{l}\text { Review authors judge that the published report } \\
\text { includes all expected outcomes, including those that } \\
\text { were pre-specified. }\end{array}$ \\
\hline Other bias & Low Risk & $\begin{array}{l}\text { The study appears to be free of other sources of } \\
\text { bias. }\end{array}$ \\
\hline
\end{tabular}

\subsubsection{Wolfe 2003}

\begin{tabular}{|c|c|}
\hline Methods & Parallel randomised controlled trial (study 1). \\
\hline Participants & $\begin{array}{l}\text { Participants: mothers of at least one child younger than five years of age recruited from parents who } \\
\text { attended lectures on discipline at day care and family support centres. } \\
\text { Sex: all mothers. } \\
\text { Age of parents: mean } 37.6 \text { years. } \\
\text { Unit of allocation: individual participant. } \\
\text { Number randomised: } 25 \text { (11 intervention; } 14 \text { control) } \\
\text { Number used in analysis: } n=25 \text { (11 intervention; } 14 \text { control)*. } \\
\text { Country \& setting: USA; single-site; recruited from community settings; intervention delivered in the } \\
\text { community. } \\
\text { Inclusion criteria: mothers with at least one child younger than five years. } \\
\text { Exclusion criteria: fathers (because of their small number). } \\
\text { Ethnicity: } 23 \text { (92\%) European American; } 2 \text { (8\%) Asian American; } 25 \text { (100\%) married; mean yearly family } \\
\text { income } \$ 60,000 \text { to } \$ 70,000 . \\
\text { Baseline characteristics: Two study conditions were comparable with respect to most demographic } \\
\text { characteristics; all participants married; mean number of children } 1.9 ; 14 \text { mothers employed. }\end{array}$ \\
\hline Interventions & $\begin{array}{l}\text { Two conditions: Listening to Children (LTC) parent education program; wait-list control. } \\
\text { Duration of intervention: } 8 \text { weeks. } \\
\text { Length of follow-up: } 3 \text { months. }\end{array}$ \\
\hline Outcomes & Stress (Parenting Stress Index). \\
\hline Futes & \\
\hline
\end{tabular}

\section{Risk of bias table}

Bias

Random sequence generation (selection Unclear Risk bias)

\section{Support for judgement}

Information reported insufficient for a judgement to be made. We requested clarification from the trial investigators, but no further information was available at the time this review was prepared.

Information reported insufficient for a judgement to be made. We requested clarification from the trial 


\begin{tabular}{|c|c|c|}
\hline \multicolumn{2}{|l|}{ Bias } & \multirow{2}{*}{$\begin{array}{l}\text { Support for judgement } \\
\text { investigators, but no further information was } \\
\text { available at the time this review was prepared. }\end{array}$} \\
\hline & & \\
\hline $\begin{array}{l}\text { Blinding (performance bias and detection } \\
\text { bias) } \\
\text { Participants }\end{array}$ & High Risk & $\begin{array}{l}\text { Review authors judge that it would not be possible } \\
\text { to fully blind participants in this type of study, and } \\
\text { found no indication of any specific additional } \\
\text { measures taken to reduce the risk of bias that might } \\
\text { result from differential behaviours by participants. }\end{array}$ \\
\hline $\begin{array}{l}\text { Blinding (performance bias and detection } \\
\text { bias) } \\
\text { Personnel }\end{array}$ & Unclear Risk & $\begin{array}{l}\text { Information reported insufficient for a judgement to } \\
\text { be made. We requested clarification from the trial } \\
\text { investigators, but no further information was } \\
\text { available at the time this review was prepared. }\end{array}$ \\
\hline $\begin{array}{l}\text { Blinding (performance bias and detection } \\
\text { bias) } \\
\text { Outcome assessors }\end{array}$ & Unclear Risk & $\begin{array}{l}\text { Information reported insufficient for a judgement to } \\
\text { be made. We requested clarification from the trial } \\
\text { investigators, but no further information was } \\
\text { available at the time this review was prepared. }\end{array}$ \\
\hline Incomplete outcome data (attrition bias) & Low Risk & There was no attrition in either group. \\
\hline Selective reporting (reporting bias) & High Risk & $\begin{array}{l}\text { Investigators do not report endpoint and follow-up } \\
\text { data for the parent-child dysfunction interaction } \\
\text { subscale of the PSI. }\end{array}$ \\
\hline Other bias & Low Risk & $\begin{array}{l}\text { The study appears to be free of other sources of } \\
\text { bias. }\end{array}$ \\
\hline
\end{tabular}

\subsubsection{Wolfson 1992}

\begin{tabular}{|c|c|}
\hline Methods & Cluster randomised controlled trial \\
\hline Participants & $\begin{array}{l}\text { Participants: first-time parent couples recruited from childbirth classes. } \\
\text { Sex: } 60 \text { mothers; } 60 \text { fathers. } \\
\text { Age of parents: mean } 28.7 \text { years. } \\
\text { Unit of allocation: childbirth class. } \\
\text { Number randomised: } 25 \text { classes (no further information); } 60 \text { couples ( } 29 \text { intervention; } 31 \text { control). } \\
\text { Number used in analysis: } 53 \text { couples ( } 26 \text { intervention; } 27 \text { control). } \\
\text { Country \& setting: USA; single-site; recruited from community settings; intervention delivered in the } \\
\text { community. } \\
\text { Inclusion criteria: parents who were expected their first child; mothers and near end of their } 7 \text { th month } \\
\text { of pregnancy; both parents between } 21 \text { and } 40 \text { years of age; married; gestational age should at least } \\
38 \text { weeks; birth weight } 5 \text { lb or more. } \\
\text { Exclusion criteria: infant with gross congenital abnormality or serious health problem. } \\
\text { Ethnicity: not stated. } \\
\text { Baseline characteristics: education: mean } 15 \text { years (SD 2.2) mothers; mean } 29.2 \text { years (SD 3.9) }\end{array}$ \\
\hline
\end{tabular}


fathers; duration of marriage: mean 3.6 years (SD 2.2).

\begin{tabular}{ll}
\hline Interventions & Two conditions: Behavioural parent programme; wait-list control. \\
& Duration of intervention: 4 weeks (2 pre-natal weekly group sessions \& 2 post-birth weekly sessions). \\
& Length of follow-up: 10 to 11 weeks. \\
\hline Outcomes & $\begin{array}{l}\text { Stress (modified Uplifts \& Hassles Scale). } \\
\text { Confidence (Parental Efficacy measure). }\end{array}$ \\
\hline Notes & \\
\hline
\end{tabular}

\section{Risk of bias table}

\begin{tabular}{|c|c|c|}
\hline Bias & & Support for judgement \\
\hline $\begin{array}{l}\text { Random sequence generation (selection } \\
\text { bias) }\end{array}$ & Unclear Risk & $\begin{array}{l}\text { Trial investigators report that "study used a } \\
\text { randomised parallel group design; a) each of } 25 \\
\text { Lamaze classes was randomly assigned to either } \\
\text { training or control condition; b) husbands and wives } \\
\text { where then recruited together as couples from these } \\
\text { assigned classes; c) to minimise group process } \\
\text { effect and group homogeneity related to Lamaze } \\
\text { classes, couples from the same Lamaze classes } \\
\text { were assigned to different training group sessions } \\
\text { and filled out forms individually; training group(n=29) } \\
\text { and control group (n=31)" (page 43). Information } \\
\text { reported insufficient for a judgement to be made. We } \\
\text { requested clarification from the trial investigators, } \\
\text { but no further information was available at the time } \\
\text { this review was prepared. }\end{array}$ \\
\hline
\end{tabular}

Allocation concealment (selection bias) Unclear Risk Information reported insufficient for a judgement to be made. We requested clarification from the trial investigators, but no further information was available at the time this review was prepared.

Blinding (performance bias and detection High Risk bias)

Participants
Review authors judge that it would not be possible to fully blind participants in this type of study, and found no indication of any specific additional measures taken to reduce the risk of bias that might result from differential behaviours by participants.

Information reported insufficient for a judgement to be made. We requested clarification from the trial investigators, but no further information was available at the time this review was prepared.

Information reported insufficient for a judgement to be made. We requested clarification from the trial 
Bias

Outcome assessors

Incomplete outcome data (attrition bias) Low Risk
Support for judgement

investigators, but no further information was available at the time this review was prepared.

There was no missing data at treatment endpoint. At follow up, $3 / 29(10 \%)$ in the intervention condition and $4 / 31(13 \%)$ in the control condition did not return to complete assessments. Review authors judge that numbers of and reasons for missing data were balanced between conditions.

Selective reporting (reporting bias) Low Risk Review authors judge that the published report includes all expected outcomes, including those that were pre-specified.

Other bias Low Risk The study appears to be free of other sources of bias. 


\subsection{CHARACTERISTICS OF EXCLUDED STUDIES}

Study

Reason for Exclusion

Al-Hassan 2011 RCT, but excluded because no standardised outcome measures.

Anastopoulos $1993 \quad$ Not randomised or quasi-randomised; pre-post test design; previously classified as a quasi-RCT using a broad definition, which no longer meets criteria.

Atherton 2007

This paper summarises findings from the Hutchings 2007a paper, which we have included.

Randomised; participants did not meet the inclusion criteria (participants are adult parents and their children between 12-17 years old); no control group (two interventions were compared); the study does not focus on psychosocial health; absence of required outcomes.

Barkby $2011 \quad$ Not an RCT.

Barkley $2001 \quad$ (two family therapies were compared); intervention was group-based; absence of psychosocial outcomes.

Barlow 2007 This paper summarises findings from the Gardner 2006 paper, which we have included.

Randomised; participants met the inclusion criterion; a wait-list control group;

Barlow 2008 intervention was not group-based (intervention was delivered on an individual basis).

$\mathrm{RCT}$; participants met the inclusion criteria; a treatment as usual control group; intervention was group-based; no data are provided on mental health measures at trial points - the investigators measured depressive symptoms

Baydar 2003 and anger/aggression at baseline, but then used the scores as indicators of risk in subsequent analysis - they provide data on the effects of these risk factors on program results, but not data on the effect of the program on mental health.

Randomised; participants met the inclusion criteria; control group did not meet Berry $2007 \quad$ the inclusion criteria as they were attending a weight loss programme at the same time; intervention was group-based; absence of psychosocial outcomes.

Randomised; participants met the inclusion criteria; a no-treatment control

Bodenmann 2008 group; intervention was group-based; outcomes assessed: the study focuses on improving parenting and child behaviour rather than parental psychosocial health.

Randomised; participants met the inclusion criteria; a wait-list control group; intervention was not solely group-based: (i) significant individual component

Bogle 2007 involved; ii) some participants received only individual component; absence of parental psychosocial outcomes. 
Bradley 2010

RCT, but excluded because intervention involved direct work with children.

Randomised; participants were parents who had been investigated for abuse or neglect; no control group (two interventions were compared; intervention was group-based.

"Quasi-experimental" design; participants pregnant or parenting chemically-

Camp 1997 dependent women; no control group (two interventions were compared); the interventions were delivered both in the groups, and on the individual basis.

Chacko $2006 \quad$ Randomised; participants met the inclusion criteria; a wait-list control group; intervention was group-based, but involved direct work with children.

Chacko 2009

Randomised; participants met the inclusion criteria; a wait-list control group; intervention was group-based, but involved direct work with children.

This paper presents recent findings from the follow-up study, where 17 programmes with a random-assignment were evaluated. Participants did not meet inclusion criteria: $39 \%$ of mothers were under 20 years old, and the results of those 20 years and older are not presented separately.

Chazan-Cohen 2007

Randomised; participants met the inclusion criteria; a wait-list control group;

Coard 2007 intervention was group-based; outcomes assessed: parenting skills; the study did not focus on parental psychosocial health.

Connell 1997

Randomised; participants met the inclusion criteria; a wait-list control group; intervention was not group-based (a telephone counselling programme).

Cooper 2009

Randomised; participants did not meet the inclusion criteria; a wait-list control group; intervention was not group-based.

Cummings 2000

Randomised; intervention was not group-based (delivered on individual basis in the home).

Randomised; participants met the inclusion criteria; no control group (two interventions were compared); the study compared outcomes in 22 mothers

Dadds 1992 of diagnosed oppositional/conduct disordered children. Two groups received parent training and one received additional social support.

Davidson $2011 \quad$ Pre-post methodology. Not an RCT.

Dekovic 2010

Not randomised. Intervention (Home Start) involved home visits.

$\mathrm{RCT}$; participants met the inclusion criteria; a wait-list control group; intervention was group-based; outcomes assessed: social skills knowledge

DeRosier $2007 \quad$ and assertive social problem-solving; the study did not focus on parental psychosocial health.

psychosocial healh.

Dionne 2009

RCT; participants met the inclusion criteria; a wait-list control group; intervention was not group-based. 
Doherty 2006

Randomised; participants met the inclusion criteria; a wait-list control group; intervention was group-based after the first session; absence of psychosocial outcomes outcomes; the focuses on the quality of father-child interaction.

Randomised; the participants met the inclusion criteria; a treatment as usual

Drew $2002 \quad$ control group; intervention was not a standard parenting programme - it consists of different category of intervention, specific to parents of children with autistic spectrum disorders.

Duch $2011 \quad$ Not randomised.

Dumas 2010 RCT, but excluded because of no relevant control condition.

Faircloth 2008

Randomised; participants met the inclusion criteria; a wait-list control group; intervention was group-based. The focus of the study is marital conflict rather than psychosocial health.

$\mathrm{RCT}$; participants were pregnant women; the intervention was not a parenting

Feinberg 2008 programme for improving psychosocial health; the study focuses on couple relationship and preparing parents for parenthood.

Randomised; participants met the inclusion criteria; a wait-list control group;

Feinfield 2004 intervention was delivered both in a group, and individually; children participated in the study and received intervention.

Florsheim 2007

Randomised controlled trial in adolescent pregnant teenagers for improving co-parenting alliance.

Forehand 2011 RCT, but excluded because no relevant outcomes.

Forgatch 1999 intervention was group-based; the study did not focus on parental psychosocial health.

Randomised; participants met the inclusion criteria; a no-treatment control group; the intervention was group-based; outcomes assessed: parent

Fossum 2009 discipline and confidence in parenting . The study focuses on the parent discipline strategies rather than parental psychosocial health.

Hahlweg $2010 \quad$ RCT, but excluded because no relevant outcomes

Harrison 1997

Randomised controlled trial. Programme offered to fathers only. Control group had videotape intervention so did not meet the inclusion criteria.

Randomised; participants met the inclusion criteria; a wait-list control group;

Havighurst 2009 the intervention was group-based; absence of relevant parent psychosocial health primary outcomes; focuses on improving child behaviour.

Randomised; participants met the inclusion criteria; a treatment as usual

Hawkins 2006 control group; intervention was self-guided, focusing on parenthood during the first year; the study did not focus on parental psychosocial health. 
Hayes 2008

Randomised; participants met the inclusion criteria; an 'enhanced' wait-list control group; the intervention was a combination of group and individual sessions.

Heinrichs 2010

RCT, but excluded because of no relevant control condition.

Helfenbaum 2007

Randomised; participants met the inclusion criteria; a no-treatment control; intervention was group-based; the study focuses on child behaviour.

Randomised: participants met the inclusion criteria; a treatment as usual control group; intervention was group-based but did not primarily focus on

Hoff 2005 improving parental psychosocial health; intervention was "specifically designed to decrease parental distress by teaching parents (of children with newly diagnosed diabetes) about the construct of uncertainty as well as uncertainty management techniques" (page 331, col 1).

Randomised; participants met the inclusion criteria; a wait-list control group; Hughes 2004 the intervention was group-based; the study focuses on parenting skills of maltreating mothers and on autonomy rather than parental psychosocial outcomes.

Not fully randomised; "initially, referrals were randomly assigned to each treatment group. Unfortunately, there were not quite as many potential Hutchings $2002 \quad$ participants as had been predicted by the pilot study to complete the study in the allocated time slot, treatment was allocated to the next intensive treatment slot as it became available group based intervention" (page 284); intervention was not group-based.

Kaaresen $2008 \quad$ Randomised; participants met the inclusion criteria; a treatment as usual control group; the intervention was not group-based.

Randomised; participants met the inclusion criteria; a no-treatment control

Kacir 1999 group; intervention was not group-based; the study did not focus on parental psychosocial health.

Kalinauskiene 2009

Randomised; participants met the inclusion criteria; a no-treatment control group; the intervention was not group-based.

Randomised; participants did not meet the inclusion criteria: in addition to parents, children were also active participants; interventions were group based, but involved direct work with children; no control group (three interventions were compared).

Kazdin 1992

Randomised; participants met the inclusion criteria; unclear whether treatment

Kazdin 2003 received by the control group qualifies as treatment as usual; intervention was not group-based.

Randomised; participants did not meet the inclusion criteria - they were

Kiebert 2005 students not adult parents; a wait-list control group; intervention was groupbased; the study did not focus on parental psychosocial health

Randomised; participants met the inclusion criteria; a no-treatment control Kim 2008 group; intervention was group-based; the study focuses on parenting skills rather than parental psychosocial health. 
Lagges 1999

Randomised; participants met the inclusion criteria; a wait-list control group; intervention was not group-based; absence of parental psychosocial health outcomes.

Not randomised, although the Abstract states that participants were

Lamb 2007 "randomly assigned to treatment or a wait-list control group"; the control group was self-selected; the participants met the inclusion criteria; WLC group; intervention was group-based.

Landy 2006

Randomised; participants met the inclusion criteria; a wait-list control group; intervention was group-based. The study focuses on parenting skills rather than parental psychosocial health.

Randomised; participants met the inclusion criteria; a treatment as usual

Lavigne 2008 control group; intervention was group-based; the study focuses on treating early childhood Oppositional Defiant Disorder rather than parental psychosocial health.

Randomised; participants met the inclusion criteria; a wait-list control group;

Leung 2003 intervention was group-based; outcomes assessed: parenting strategies. The study focuses on parenting skills and strategies rather than parental psychosocial health.

Randomised; participants met the inclusion criteria; a wait-list control group;

$\operatorname{Lim} 2005$ intervention was group-based; outcomes assessed: parenting strategies; the study focuses on parenting skills and strategies rather than parental psychosocial health.

Randomised; participants met the inclusion criteria; a treatment as usual Linares $2006 \quad$ control group; intervention comprises of a similar number of group-based and individually-based sessions; the individual sessions involved children.

Randomised; participants met the inclusion criteria; a no-treatment control Martinez 2001 group; intervention was group-based; the study did not focus on parenting psychosocial outcomes.

Randomised; participants met the inclusion criteria; a no-treatment control group; intervention was group-based; outcomes assessed: parenting practices, parenting skills, and general parenting; the study focuses on parenting skills rather than parental psychosocial health.

Matos 2009

Randomised; participants met the inclusion criteria; a wait-list control group; intervention was not group-based.

Cluster-randomised; participants did not meet inclusion criteria: participants

Matthey 2004 were couples who were expected their first child; a treatment as usual control group; intervention was group-based; the study focuses on preparation for parenthood rather than parental psychosocial health.

McCabe 2009

Randomised; participants met the inclusion criteria; a treatment as usual control group; intervention was not group-based.

Randomised; participants met the inclusion criteria; control condition appeared to be a 'treatment as usual' plus special education and therapeutic

McIntyre 2008 services with a family focused orientation. Study focused on prevention of severe behaviour problem in children and was not focused on parental psychosocial health, therefore no parental psychosocial outcomes were obtained or reported. 
Melnyk 2007

Randomised; participants met the inclusion criteria; control condition appeared to be a 'placebo group'; intervention was not group-based.

Mendelsohn 2007 Randomised; participants met the inclusion criteria; a treatment as usual control group; intervention was not group-based.

Miller-Heyl 1998

Randomised; participants did not meet the inclusion criteria: joint intervention directed at parents and their children; a no-treatment control group; intervention was group-based.

Mullin 1994

Not randomised or quasi-randomised: pre-post test design; previously classified as a quasi-RCT using a broad definition, which no longer meets criteria.

NCT00183365 RCT, but excluded because of no relevant control condition.

Nixon 2004

Randomised; participants met the inclusion criteria; a wait-list control group; intervention was not group-based.

Ogden 2008

Randomised; participants met the inclusion criteria; a treatment as usual control group; intervention was not group-based.

Olivares 1997

Randomised controlled study, but no comparison of some outcomes in the control group.

Openden 2005

Randomised; participants a control group met the inclusion criteria; intervention was not group-based; absence of parental psychosocial outcomes.

Orrell-Valente 1999

Randomised; participants met the inclusion criteria; no information about the control condition given; intervention included a home visiting component which might confound the results of the parenting programme.

Design: the first treatment group was not randomised, while the second and third treatment groups, and the control group were randomised; participants

Ostergren 2003 met the inclusion criteria; a no-treatment control group; intervention was not group-based.

Plant 2007

Randomised; participants met the inclusion criteria; a wait-list control group; intervention was not group-based.

Randomised; participants did not meet the inclusion criteria; some pregnant

Rahman 2009 women were included; a no-treatment control group; intervention comprises of both group-based and individually-based sessions.

Randomised; participants met the inclusion criteria; a no-treatment control

Rapee 2005 group; intervention was group-based; The study focuses on preventing the development of anxiety in preschool children rather than parental psychosocial health.

Randomised controlled trial, participants met the inclusion criteria.

Reid 2001 Combination of results from two Incredible Years Parenting Programs. Control group did not meet the inclusion criteria (the studies compare two treatment 
conditions). Focuses on parenting skills. 


\begin{tabular}{ll}
\hline Study & Reason for Exclusion \\
\hline Reid 2004 & $\begin{array}{l}\text { Randomised; participants met the inclusion criteria; a treatment as usual } \\
\text { control group; intervention was group-based; absence of parental } \\
\text { psychosocial health outcomes; the study focuses on engagement in the } \\
\text { program and parenting. }\end{array}$ \\
\hline Ruffolo 2005 & $\begin{array}{l}\text { Randomised; participants met the inclusion criteria; a treatment as usual } \\
\text { control group; intervention was group-based; outcomes assessed: parental } \\
\text { attitudes towards family functioning (F-COPES; PLOC); the study did not } \\
\text { focus on parental psychosocial health. }\end{array}$ \\
\hline Sanders 2000 & $\begin{array}{l}\text { Randomised; participants met the inclusion criteria; a wait-list control group; } \\
\text { interventions were not group-based. }\end{array}$ \\
\hline Sanford 2003 & $\begin{array}{l}\text { Randomised; participants did not meet the inclusion criteria: the study focuses } \\
\text { solely on families with a parent with clinical depression; WLC group; } \\
\text { intervention was group-based. }\end{array}$ \\
\hline Sawasdipanich 2010 & $\begin{array}{l}\text { RCT but excluded because intervention involved home visits and the lack of } \\
\text { any relevant outcome measures. }\end{array}$ \\
\hline
\end{tabular}

Scott $1987 \quad$ Allocation by group alternation.

Scott $2002 \quad$ Randomised; a multi-faceted programme, including child literacy; the study did not focus on improving parental psychosocial health.

This study is follow-up of an original trial (Scott 2001) that was RCT. Follow-

Scott $2005 \quad$ up was only attempted on those allocated to the intervention condition. Participants in the control condition received the same group parenting training at this time point.

Randomised; participants met the inclusion criteria; a wait-list control group; Scott 2009 intervention was group-based; outcomes assessed: positive involvement, appropriate discipline, inconsistent parenting, and harsh discipline. The study focuses on parenting strategies rather than parental psychosocial health.

Sheeber $1994 \quad$ Partially randomised trial.

Randomised; participants met the inclusion criteria; a wait-list control group; Shifflett 1999 intervention was group based; the study focuses on parenting behaviour only rather than on parental psychosocial health.

Singer $1999 \quad$ Randomised; intervention was not group-based

Sonuga-Barke 2001 Randomised; a wait-list control group; intervention was not group-based (an individually-based intervention).

Sonuga-Barke 2002 Randomised; intervention was not group-based (an individually-based intervention). 
St James Roberts 2001

Randomised; intervention was not group-based (a leaflet programme).

Steiman 2005

This dissertation is a retrospective analysis of three experimental studies (randomised design).

Randomised; participants did not meet the inclusion criteria: participants were

Suchman 2004 mother who had a specific psychiatric disorder and were receiving methadone therapy; control group did not meet the inclusion criteria; intervention was group-based.

Suess 2005

Randomised; participants met the inclusion criteria; unclear control group condition; intervention was not group-based (be-weekly home visits).

Randomised; comparisons between three treatment modes and a control

Sutton 1992 group; outcomes assessed: stress; outcome measure was not validated (an 'ad hoc' measure used).

Sutton 1995

Randomised; a wait-list control group; intervention was not group-based: telephone based parent training intervention.

Thompson $2009 \quad$ Randomised; participants met the inclusion criteria; a treatment as usual control group; intervention was not group-based.

Thompson 2010

$\mathrm{RCT}$, but excluded because intervention involved home visits and direct work with children.

Not all participants were randomised: "at each one of the locations, maximum of 26 parents could be accepted to the programme, and if the number who

Thorell 2009 applied was higher than 26 , parent were randomly assigned to either the parent training group or to a wait-list control group. However, in 8 out of 10 areas, all interested parents could be admitted to the programme. A total of 275 families attended the first introductory session" (page 376).

Randomised; participants met the inclusion criteria; a no-treatment control

Tonge 2006 group; intervention consisted of 10 group-based and 10 individual sessions. Individual sessions play equal role as group sessions in the intervention.

Randomised; participants met the inclusion criteria; a wait-list control group;

Trost 2007 intervention was group-based; absence of required outcomes; the study focuses on the role of parenting involvement in Eating Disorder prevention of their children, rather than parental psychosocial health.

Randomised; participants met the inclusion criteria; a no-treatment control group; intervention was group-based; outcomes assessed: post-natal

Turner 2006a depression; outcome measure (a qualitative outcome measure used) was not standardised.

Randomised; participants met the inclusion criteria; a treatment as usual Uslu 2006 control group; intervention was group-based; the study focuses on parental expressed emotion towards children with learning disorders rather than parental psychosocial health. 
Randomised; participants met the inclusion criteria; a no-treatment control

Van Wyk $1983 \quad$ group; intervention was group-based; outcome assessed: personality outcomes; not focused on improving parental mental health or parenting. Previously classified as included study.

Randomised; participants did not meet the inclusion criteria: in addition to

Webster-Stratton 2001 parents, teachers and social workers were also involved in the programme; intervention was group-based; the study did not focus on parental psychosocial health.

Webster-Stratton 2004

Randomised; participants met the inclusion criteria; a wait-list control group; intervention was group-based; the study focuses on parenting skills rather than parental psychosocial health.

Randomised; participants met the inclusion criteria; unclear whether the control group met the inclusion criteria; intervention was group-based; the study focuses on preparing for parenthood rather than parental psychosocial health.

Wheatley 2003

Randomised; participants met the inclusion criteria; a wait-list control group;

Whitehurst 2008 intervention was group-based; the study focuses on conflict between divorced and separated parents rather than parental psychosocial health.

Randomised; participants met the inclusion criteria; a wait-list control group; intervention included some individual sessions with parents; outcomes

Whittingham 2009a assessed: parenting skills and perception of parenting skills; the study focuses on parenting skills strategies rather than parental psychosocial health.

Randomised; participants met the inclusion criteria; a wait-list control group; intervention included some individual sessions with parents; outcomes

Whittingham 2009b assessed: parenting skills and perception of parenting skills; the study focuses on parenting skills strategies rather than parental psychosocial health.

Randomised; participants met the inclusion criteria; a wait-list control group; intervention included some individual sessions with parents; outcomes

Wiggins $2009 \quad$ assessed: parenting skills; the study focuses on parenting skills strategies and promoting positive parent-child relationship rather than parental psychosocial health.

Randomised; participants met the inclusion criteria: participants were service providers; a wait-list control group; intervention was group-based; the study

Wissow 2008 focuses on impact of brief provider communication training with respect to mental health of parents and children.

Randomised; participants met the inclusion criteria; a wait-list control group;

Wolkchik 1993 intervention was group-based; the study focuses on parenting skills strategies, mother-child relationship and negative divorce events rather than parental psychosocial health.

Randomised; participants met the inclusion criteria; a no-treatment control group; intervention was group-based; outcomes assessed: parenting skills scales and family strengths ; previously classified as included study; now excluded on the basis that the study focuses on the influence of parenting skills strategies on family functioning and has no measures of parental psychosocial health. 


\subsection{CHARACTERISTICS OF STUDIES AWAITING CLASSIFICATION}

\subsubsection{Bayer 2010}

\begin{tabular}{ll}
\hline Methods & Cluster-randomised controlled trial \\
\hline Participants & $\begin{array}{l}40 \text { primary care nursing centres; } 733 \text { English-speaking mothers of } 6 \text { to } 7 \text { month old } \\
\text { infants consecutively recruited from well-child appointments of which } 80 \% \text { retained at } \\
\text { age } 3 \text { years }\end{array}$ \\
\hline Interventions & 'Toddlers Without Tears' parenting programme \\
\hline Outcomes & $\begin{array}{l}\text { Maternal mental health (Depression Anxiety Stress Scales), child externalising } \\
\text { behaviour, parenting }\end{array}$ \\
\hline Notes & \\
\hline
\end{tabular}

\subsubsection{Bywater 2011}

\begin{tabular}{ll}
\hline Methods & Randomised controlled trial \\
\hline Participants & 46 foster carers \\
\hline Interventions & Incredible Years programme \\
\hline Outcomes & Depression, child behaviour, service use, parenting competency \\
\hline Notes & \\
\hline
\end{tabular}

\subsubsection{Cefai 2010}

\begin{tabular}{ll}
\hline Methods & Randomised controlled trial (3 conditions) \\
\hline Participants & 116 parents \\
\hline Interventions & $\begin{array}{l}\text { Group-based programme (2 sessions); individual self-administered intervention (2 } \\
\text { sessions); wait-list control }\end{array}$ \\
\hline Outcomes & Sense of competence, parental satisfaction, child problem behaviour \\
\hline Notes & \\
\hline
\end{tabular}

\subsubsection{Eichelberger 2010}

\begin{tabular}{ll}
\hline Methods & Randomised controlled study \\
\hline Participants & 93 families of 3-6 year old German pre-school children \\
\hline Interventions & Triple P parent group training \\
\hline Outcomes & $\begin{array}{l}\text { Psychological distress, child behaviour problems, parenting strategies and } \\
\text { partnership satisfaction }\end{array}$ \\
\hline
\end{tabular}




\subsubsection{Franz 2007}

\begin{tabular}{ll}
\hline Methods & Randomised controlled study \\
\hline Participants & 61 single mothers suffering from medium grade psychosocial impairment \\
\hline Interventions & An emotion oriented parent training programme, based on attachment theory \\
\hline Outcomes & $\begin{array}{l}\text { Psychological impairment, depression and emotional competence. Child behavioural } \\
\text { problems }\end{array}$ \\
\hline Notes & Obtain full translation \\
\hline
\end{tabular}

\subsubsection{Hampel 2010}

\begin{tabular}{ll}
\hline Methods & Unclear; translation required; ? multicentre randomised trial \\
\hline Participants & Unclear; translation required; ? families with a handicapped child \\
\hline Interventions & Stepping Stones Triple P group parent training \\
\hline Outcomes & Parental stress, dysfunctional parenting, and child behaviour problems \\
\hline Notes & Obtain full translation \\
\hline
\end{tabular}

\subsubsection{Heinrichs 2006}

\begin{tabular}{ll}
\hline Methods & Cluster-randomised (by pre-school) into parent training or control group \\
\hline Participants & 219 two-parent families \\
\hline Interventions & Triple P parent group training \\
\hline Outcomes & Parenting, child behaviour, psychological distress, relationship satisfaction \\
\hline Notes & Obtain full translation \\
\hline
\end{tabular}

\subsubsection{Morawska 2011}

\begin{tabular}{ll}
\hline Methods & Randomised controlled trial \\
\hline Participants & 67 parents of children aged 2 to 5 years \\
\hline Interventions & $\begin{array}{l}\text { Single session discussion group on positive parenting plus two follow up telephone } \\
\text { calls }\end{array}$ \\
\hline Outcomes & Depressive symptoms; confidence; partner satisfaction \\
\hline Notes & \\
\hline
\end{tabular}

\subsubsection{Naumann 2007}

Methods Randomised controlled trial




\begin{tabular}{ll}
\hline Participants & 280 families \\
\hline Interventions & Triple P parent training or control group \\
\hline Outcomes & Parental competencies \\
\hline Notes & Obtain full translation \\
\hline
\end{tabular}

\subsubsection{Reedtz 2011}

\begin{tabular}{ll}
\hline Methods & Randomised controlled trial \\
\hline Participants & 186 parents of children aged 2 to 8 years \\
\hline Interventions & Short parenting programme (Incredible Years) \\
\hline Outcomes & Sense of competence, parenting skills \\
\hline Notes & \\
\hline
\end{tabular}

\subsubsection{Sanders 2011}

\begin{tabular}{ll}
\hline Methods & Randomised controlled trial \\
\hline Participants & 121 working parents with children between 1 and 16 years \\
\hline Interventions & Workplace Triple P group intervention \\
\hline Outcomes & $\begin{array}{l}\text { Personal distress, dysfunctional parenting, work commitment, work satisfaction and } \\
\text { self-efficacy }\end{array}$ \\
\hline Notes & \\
\hline
\end{tabular}

\subsection{CHARACTERISTICS OF ONGOING STUDIES}

\subsubsection{NTR1338}

\begin{tabular}{ll}
\hline Study name & $\begin{array}{l}\text { RCT of the positive parenting programme (Triple P) versus care as usual } \\
\text { provided by the preventive child healthcare system }\end{array}$ \\
\hline Methods & RCT \\
\hline Participants & $\begin{array}{l}\text { Parents of 9-11 year old primary school children in the Netherlands with } \\
\text { increased but subclinical levels of psychosocial problems }\end{array}$ \\
\hline Interventions & Triple-P (level 3) versus care-as-usual control \\
\hline Outcomes & $\begin{array}{l}\text { Child problem behaviour; parenting behaviour; parenting stress (including } \\
\text { depression and anxiety symptoms) }\end{array}$ \\
\hline Starting date & Registered in 2008; results available 2012 \\
\hline Contact information & W.spijkers@med.umcg.nl \\
\hline Notes & Trial registration: NTR1338 \\
\hline
\end{tabular}




\section{References to studies}

\subsection{INCLUDED STUDIES}

\section{Blakemore 1993}

Blakemore B, Shindler S, Conte R. A problem solving training program for parents of children with attention deficit hyperactivity disorder. Canadian J ournal of School Psychology 1993;9(1):66-85.

\section{Bradley 2003}

Bradley SJ , J adda DA, Brody J , Landy S, Tallett SE, Watson W et al. Brief psychoeducational parenting program: an evaluation and 1-year follow-up. J ournal of the American Academy of Child and Adolescent Psychiatry 2003;42(10):1171-8. [MEDLINE: 1530; Other: CN-00450578]

\section{Chronis 2006}

Chronis A. The addition of the "coping with depression course" to behavioral parent training for mothers of children with attention deficit hyperactivity disorder. Dissertation Abstracts International 2003;63(8-B):3907. [MEDLINE: 1760; Other: CN-00462983] Chronis AM, Gamble SA, RobertsJ E, Pelham WE. Cognitive-behavioral depression treatment for mothers of children with attentiondeficit/ hyperactivity disorder. BehaviorTherapy 2006;37:143-58. [MEDLINE: 24790]

\section{Cunningham 1995}

Cunningham CE, Bremner R, Boyle M. Large group community-based parenting programs for families of preschoolers at risk for disruptive behaviour disorders: utilization, cost-effectiveness, and outcome. J ournal of Child Psychology and Psychiatry and Allied Disciplines 1995;36(7):1141-59.

\section{DeGarmo 2004}

DeGarmo DS, Patterson GR, Forgatch MS. How do outcomes in a specified parent training intervention maintain or wane over time? Prevention Science 2004;5(2):73-89. [MEDLINE: 1250; Other: CN-00467503] 


\section{Fanning 2007}

Fanning J L. Parent Training for Caregivers of Typically Developing,

Economically Disadvantaged Preschoolers: An Initial Study in Enhancing Language Development, Avoiding Behavior Problems, and Regulating Family Stress (PhD thesis). Oregon: University of Oregon, 2007.

\section{Fantuzzo 2007}

Fantuzzo J , Stevenson H, Abdul Kabir S, Perry MA. An investigation of a community-based Intervention for socially isolated parents with a history of child maltreatment. J ournal of Family Violence 2007;22:81-9. [MEDLINE: 36550; Other: 0885-7482]

\section{Farrar 2005}

Farrar RLE. The Effect of a Cognitively Based Parent Training Intervention on Parental Stress. Tulsa, OK: The University of Tulsa, 2005. [MEDLINE: 28450]

\section{Feliciana 2005}

Feliciana J B. The Impact of Participation in a Parent Training Program on Maternal Sense of Competency and Stress in Urban African-American Mothers. Washington, DC: Howard University, 2005.

\section{Gallart 2005}

Gallart SC Matthey S. The effectiveness of group Triple P and the impact of the four telephone contacts. Behaviour Change 2005;22(2):71-80. [MEDLINE: 940; Other: CN-00569669]

\section{Gammon 1991}

Gammon EA, Rose SD. The coping skills training program for parents of children with developmental disabilities: an experimental evaluation. Research on Social Work Practice 1991;1(3):244-56.

\section{Gardner 2006}

Gardner F Burton J , Klimes I. Randomised controlled trial of a parenting intervention in the voluntary sector for reducing child conduct problems: outcomes and mechanisms of change. J ournal of Child Psychology and Psychiatry, and Allied Disciplines 2006;47(11):1123-32. [MEDLINE: 410; Other: CN-00573306]

\section{Greaves 1997}

Greaves D. The effect of rational-emotive parent education on the stress of mothers of children with Down Syndrome. J ournal of Rational-Emotive and Cognitive-Behavior Therapy 1997;15(4):249-67. 


\section{Gross 1995}

Gross D, Fogg L, Tucker S. The efficacy of parent training for promoting positive parent-toddler relationships. Research in Nursing and Health 1995;18(6):48999.

Tucker S, Gross D, Fogg L, Delaney K, Lapporte R. The long-term efficacy of a behavioural parent training intervention for families with 2-year-olds. Research in Nursing and Health 1998;21(3):199-210.

\section{Gross 2003}

Gross D, Fogg L, Webster-Stratton C, Garvey C, J ulion W, Grady J . Parent training of toddlers in day care in low-income urban communities. J ournal of Consulting and Clinical Psychology 2003;71(2):261-78. [MEDLINE: 40040; Other: 0022-006X]

\section{Gross 2009}

Gross D, Garvey C, J ulion W, Fogg L, Tucker S, Mokros H. Efficacy of the Chicago parent program with low-income African American and Latino parents of young children. Prevention Science: the official journal of the Society for Prevention Research 2009;10(1):54-65.

\section{Gutierrez 2007}

Gutierrez SR. A Comparison of Two Parent Education Programs on the Reduction of Parent-Child Stress in Mother-Child Relationships of Hispanic Migrant Farmworkers. Tucson, AZ: The University of Arizona, 2007. [MEDLINE: 22000]

\section{Hanisch 2010}

Hanisch C, Freund-Braier I, Hautmann C, J anen N, Pluck J , Brix G et al. Detecting effects of the indicated prevention programme for externalizing problem behaviour (PEP) on child symptoms, parenting, and parental quality of life in a randomized controlled trial. Behavioural and Cognitive Psychotherapy 2010;38(1):95-112. [Other: 1469-1833]

\section{Hiscock 2008}

Hiscock H, Bayer J K, Price A, Ukoumunne OC, Rogers S, Wake M. Universal parenting programme to prevent early childhood behavioural problems: cluster randomised trial. BMJ 2008;336(7639):318-21. [MEDLINE: 450; Other: 0959535X]

Hutchings J . A parenting programme does not affect behavioural problems in toddlers. Evidence-Based Mental Health 2008;11(4):119. [Other: 1362-0347]

\section{Hutchings 2007}

Bywater T, Hutchings J , Daley D, Whitaker C, Yeo ST, J ones K et al. Long-term effectiveness of a parenting intervention for children at risk of developing 
conduct disorder. British J ournal of Psychiatry 2009;195(4):318-24. [Other: 0007-1250]

Eames C, Daley D, Hutchings J, Whitaker C, Bywater T, J ones K, Hughes J. The impact of group leaders' behaviour on parents acquisition of key parenting skills during parent training. Behaviour Research and Therapy 2010;48(12):1221-6. Hawkins-Walsh E. A cognitive-behavioural parenting intervention reduced problem behaviours in at-risk preschool children and improved parenting skills in socially disadvantaged families. Evidence-Based Nursing 2007;10(4):105. [MEDLINE: 40610; Other: 1367-6539] Hutchings J GF, Bywater T, Daley D, Whitaker C, J ones K, Eames C et al. Parenting intervention in Sure Start services for children at risk of developing conduct disorder: pragmatic randomised controlled trial. BMJ 2007;334(7595):678. [MEDLINE: 90; Other: CN-00579132]

\section{Irvine 1999}

Irvine AB, Biglan A, Smolkowski K, Metzler CW, Ary DV. The effectiveness of a parenting skills program for parents of middle school students in small communities. J ournal of Consulting and Clinical Psychology 1999;67(6):811-25.

\section{J oachim 2010}

J oachim S, Sanders MR, Turner KMT. Reducing preschoolers' disruptive behavior in public with a brief parent discussion group. Child Psychiatry and Human Development 2010;41(1):47-60. [Other: 0009-398X]

\section{J oyce 1995}

J oyce MR. Emotional relief for parents: is rational-emotive parent education effective? J ournal of Rational-Emotive and Cognitive-Behavior Therapy 1995; 13(1):55-75.

\section{Larsson 2009}

Larsson B, Fossum S, Clifford G, Drugli MB, Handegård BH, Mørch W. Treatment of oppositional defiant and conduct problems in young Norwegian children: results of a randomized controlled trial. European Child and Adolescent Psychiatry 2009;18(1):42-52. [Other: 1018-8827]

\section{Lipman 2005}

Lipman EL, Boyle MH. Social support and education groups for single mothers: a randomized controlled trial of a community-based program. Canadian Medical Association J ournal 2005;173(12):1451-6. [MEDLINE: 910; Other: CN00553003]

\section{Martin 2003}

Martin AJ , Sanders MR. Balancing work and family: A controlled evaluation of the Triple P-Positive Parenting Program as a work-site intervention. Child and Adolescent Mental Health 2003;8(4):161-9. [MEDLINE: 35040] 


\section{Matsumoto 2007}

Matsumoto Y, Sofronoff K, Sanders MR. The efficacy and acceptability of the Triple P-positive parenting program with J apanese parents. Behaviour Change 2007;24(4):205-18. [MEDLINE: 49240]

\section{Matsumoto 2010}

Matsumoto Y, Sofronoff K, Sanders MR. Investigation of the effectiveness and social validity of the Triple P Positive Parenting Program in J apanese society. J ournal of Family Psychology 2010;24(1):87-91. [Other: 0893-3200]

\section{McGillicuddy 2001}

McGillicuddy NB, Rychtarik RG, Duquette JA, Morsheimer T. Development of a skill training program for parents of substance-abusing adolescents. J ournal of Substance Abuse Treatment 2001;20(1):59-68.

\section{Morawska 2009}

Morawska A, Sanders M. An evaluation of a behavioural parenting intervention for parents of gifted children. Behaviour Research and Therapy 2009;47(6):46370. [Other: 0005-7967]

\section{Niccols 2009}

Niccols A. Immediate and short-term outcomes of the 'COPEing with toddler behaviour' parent group. J ournal of Child Psychology and Psychiatry and Allied Disciplines 2009;50(5):617-26.

\section{Nicholson 2002}

Nicholson B, Anderson M, Fox R, Brenner V. One family at a time: a prevention program for at-risk parents. J ournal of Counseling \& Development 2002;80(3):362-71.

\section{Nixon 1993}

Nixon CD, Singer GHS. Group cognitive-behavioral treatment for excessive parental self-blame and guilt. American J ournal on Mental Retardation 1993;97(6):665-72.

\section{Odom 1996}

Odom SE. Effects of an educational intervention on mothers of male children with attention deficit hyperactivity disorder. J ournal of Community Health Nursing 1996;13(4):207-20.

\section{Patterson 2002}

Patterson J , Barlow J , Mockford C, Klimes I, Pyper C, Stewart-Brown S. Improving mental health through parenting programmes: block randomised controlled trial. Archives of Disease in Childhood 2002;87:472-77. 
Reading R. Impact of a general practice based group parenting programme: quantitative and qualitative results from a controlled trial at 12 months. Child: Care, Health and Development 2004;30(5):560-1. [MEDLINE: 32610] Stewart Brown SPJ , Mockford C, BarlowJ , Klimes I, Pyper C. Impact of a general practice based group parenting programme: quantitative and qualitative results from a controlled trial at 12 months. Archives of Disease in Childhood 2004;89(6):519-25. [MEDLINE: 1260; Other: CN-00469249]

\section{Pisterman 1992a}

Pisterman S, Firestone P, McGrath P, Goodman JT, Webster I, Mallory R et al. The effects of parent training on parenting stress and sense of competence. Canadian J ournal of Behavioural Science 1992;24(1):41-58.

\section{Pisterman 1992b}

Pisterman S, Firestone P, McGrath P, Goodman JT, Webster I, Mallory R et al. The role of parent training in treatment of preschoolers with ADHD. American J ournal of Orthopsychiatry 1992;62(3):397-407.

\section{Schultz 1993}

Schultz CL, Schultz NC, Bruce EJ , Smyrnios KX, Carey LB, Carey CL. Psychoeducational support for parents of children with intellectual disability. International J ournal of Disability, Development and Education 1993;40(3):205-16.

\section{Sirbu 1978}

Sirbu W, Cotler S, J ason LA. Primary prevention: teaching parents behavioral child rearing skills. Family Therapy 1978;5(2):163-70.

\section{Spaccerelli 1992}

Spaccarelli S, Cotler S, Penman D. Problem-solving skills training as a supplement to behavioral parent training. Cognitive Therapy and Research 1992;16(1):1-18.

\section{Taylor 1998}

Taylor TK, Schmidt F, Pepler D, Hodgins C. A comparison of eclectic treatment with Webster-Stratton's parents and children series in a children's mental health center: a randomised controlled trial. Behavior Therapy 1998;29(2):221-40.

\section{Treacy 2005}

Treacy L, Tripp G, Baird A. Parent stress management training for attentiondeficit/hyperactivity disorder. Behavior Therapy 2005;36(3):223-33.

[MEDLINE: 19230] 


\section{Turner 2007}

Turner KM, Richards M, Sanders MR. Randomised clinical trial of a group parent education programme for Australian Indigenous families. J ournal of Paediatrics and Child Health 2007;43(6):429-37. [MEDLINE: 130; Other: CN00615331]

Turner KMT, Sanders MR, Richards M, Arthur N. Tailoring and evaluating an evidence-based group family intervention program for parents in indigenous communities. In: Katsikitis M, editor(s). Australian J ournal of Psychology; Proceedings The Abstracts of the J oint Conference of the Australian Psychological Society and the New Zealand Psychological Society. Vol. 58. London: Taylor and Francis, 2006:201. [MEDLINE: 55260]

\section{van den Hoofdakker 2007}

van Den Hoofdakker BJ , van der Veen-Mulders LL, Sytema S, Emmelkamp PMG, Minderaa RB, Nauta MH. Effectiveness of behavioral parent training for children with ADHD in routine clinical practice: a randomized controlled study. J ournal of the American Academy of Child and Adolescent Psychiatry 2007;46(10):1263-71. [MEDLINE: 14460]

\section{Wang 2005}

Wang P. Effects of a Parent Training Program for Teaching Children with Autism in the People's Republic of China (PhD thesis). New York, NY: Columbia University, 2005.

\section{Webster Stratton 1988}

Webster-Stratton C, Kolpacoff M, Hollinsworth T. Self-administered videotape therapy for families with conduct-problem children: comparison with two costeffective treatments and a control group. J ournal of Consulting and Clinical Psychology 1988;56(4):558-66.

\section{Wolfe 2003}

Wolfe RB, Hirsch BJ . Outcomes of parent education programs based on reevaluation counseling. J ournal of Child and Family Studies 2003;12(1):61-76. [MEDLINE: 40070; Other: 1062-1024]

\section{Wolfson 1992}

Wolfson A, Lacks P, Futterman A. Effects of parent training on infant sleeping patterns, parents stress, and perceived parental competence. J ournal of Consulting and Clinical Psychology 1992;60(1):41-8. 


\section{Al-Hassan 2011}

Al-Hassan SM, Lansford J E. Evaluation of the better parenting programme in J ordan. Early Child Development and Care 2011;181(5):587-98.

\section{Anastopoulos 1993}

Anastopoulos AD, Shelton TL, DuPaul GJ , Guevremont DC. Parent training for attention-deficit hyperactivity disorder: its impact on parent functioning. J ournal of Abnormal Child Psychology 1993;21(5):581-96.

\section{Atherton 2007}

Atherton C. The Incredibles. Community Care 2007; 1673:32-33. [MEDLINE: 38100; Other: 0307-5508]

\section{Azrin 2001}

Azrin NH, Donohue B, Teichner GA, Crum T, Howell J , Decato LA. A controlled evaluation and description of individual-cognitive problem solving and familybehavior therapies in dually-diagnosed conduct-disordered and substancedependent youth. J ournal of Child \&Adolescent Substance Abuse 2001;11(1):143.

\section{Barkby 2011}

Barkby H, Butterworth R, Davies J , Marsland L, O'Shaughnessy R. Bonding with baby: A pilot parent-infant intervention programme in Liverpool. Clinical Psychology Forum 2011;224:17-21.

\section{Barkley 2001}

Barkley RA, Edwards G, Laneri M, Fletcher K, Metevia L. The efficacy of problem-solving communication training alone, behavior management training alone, and their combination for parent-adolescent conflict in teenagers with ADHD and ODD. J ournal of Consulting and Clinical Psychology 2001;69(6):926-41.

\section{Barlow 2007}

BarlowJ . The Webster-Stratton "Incredible Years" parent training programme reduces conduct problems in children. Evidence-Based Mental Health 2007;10(3):86. [MEDLINE: 41050; Other: 1362-0347]

\section{Barlow 2008}

Barlow J H, Powell LA, Gilchrist M, Fotiadou M. The effectiveness of the training and support program for parents of children with disabilities: a randomized controlled trial. J ournal of Psychosomatic Research 2008;64(1):55-62.

[MEDLINE: 21050] 


\section{Baydar 2003}

Baydar N, Reid MJ , Webster Stratton C. The role of mental health factors and program engagement in the effectiveness of a preventive parenting program for Head Start mothers. Child Development 2003;74(5):1433-53. [MEDLINE: 1800; Other: CN-00458200]

\section{Berry 2007}

Berry D, Savoye M, Melkus G, Grey M. An intervention for multiethnic obese parents and overweight children. Applied Nursing Research 2007;20(2):63-71. [MEDLINE: 41690; Other: 0897-1897]

\section{Bodenmann 2008}

Bodenmann G, Cina A, Ledermann T, Sanders MR. The efficacy of the Triple PPositive Parenting Program in improving parenting and child behavior: a comparison with two other treatment conditions. Behaviour Research and Therapy 2008;46(4):411-27. [MEDLINE: 400; Other: 0005-7967]

\section{Bogle 2007}

Bogle KE. Evaluation of a Brief Group Parent Training Intervention in the Context of an After-School Program for Middle-School Students. South Carolina: University of South Carolina, 2007.

\section{Bradley 2010}

Bradley R, Whiteside-Mansell L, Casey P, Barrett K. Impact of a two-generation early education program on parenting processes at age 18. J ournal of Family Psychology 2010;24(4):478-84.

\section{Brunk 1987}

Brunk M, Henggeler SW, Whelan J P. Comparison of multisystemic therapy and parent training in the brief treatment of child abuse and neglect. J ournal of Consulting and Clinical Psychology 1987;55(2):171-8.

\section{Camp 1997}

CampJ M, Finkelstein N. Parenting training for women in residential substance abuse treatment. J ournal of Substance Abuse Treatment 1997;14(5):411-22.

\section{Chacko 2006}

Chacko A. Treatment for Single-Mothers of Children Diagnosed with ADHD: A Comparison between a Traditional and an Enhanced Behavioral Parenting Program. New York: State University of New York at Buffalo, 2006. [MEDLINE: 22200] 


\section{Chacko 2009}

Chacko A, Wymbs BT, Wymbs FA, Pelham WE, Swanger-Gagne MS, Girio E et al. Enhancing traditional behavioral parent training for single mothers of children with ADHD. J ournal of Clinical Child and Adolescent Psychology 2009;38(2):206-18.

\section{Chazan-Cohen 2007}

Chazan-Cohen R, Ayoub C, Pan BA, Roggman L, Raikes H, Mckelvey L et al. It takes time: impacts of early Head Start that lead to reductions in maternal depression two years later. Infant Mental Health J ournal 2007;28(2):151-70. [MEDLINE: 54660]

\section{Coard 2007}

Coard SI, Foy-Watson S, Zimmer C, Wallace A. Considering culturally relevant parenting practices in intervention development and adaptation: a randomized controlled trial of the black parenting strengths and strategies (BPSS) program. The Counseling Psychologist 2007;35(6):797-820. [MEDLINE: 50310]

\section{Connell 1997}

Connell S, Sanders MR, Markie-Dadds C. Self-directed behavioral family intervention for parents of oppositional children in rural and remote areas. Behavior Modification 1997;21(4):379-408.

\section{Cooper 2009}

Cooper PJ , Tomlinson M, Swartz L, Landman M, Molteno C, Stein A et al. Improving quality of mother-infant relationship and infant attachment in socioeconomically deprived community in South Africa: randomised controlled trial. BMJ 2009;338(7701):997. [Other: 0959-8146]

\section{Cummings 2000}

Cummings LL. Parent training: A Program for Parents of Two- and Three-yearolds (PhD thesis). Mount Pleasant, MI: Central Michigan University, 2000.

\section{Dadds 1992}

Dadds MR, McHugh TA. Social support and treatment outcome in behavioral family therapy for child conduct problems. J ournal of Consulting and Clinical Psychology 1992;60(2):252-9.

\section{Davidson 2011}

Davidson VL. A Parent Training Program for Caucasian and Latino Parents of Children with Developmental Delays or Behavioral Difficulties (Psy D dissertation). Chicago, Illinois: Chicago School of Professional Psychology, 2011. 


\section{Dekovic 2010}

Dekovic M, Asscher JJ , Hermanns J , Reitz E, Prinzie P, van den Akker AL. Tracing changes in families who participated in the home-start parenting program: parental sense of competence as mechanism of change. Prevention Science 2010;11(3):263-74.

\section{DeRosier 2007}

DeRosier ME, Gilliom M. Effectiveness of a parent training program for improving children's social behavior. J ournal of Child and Family Studies 2007;16(5):660-70. [Other: 1062-1024]

\section{Dionne 2009}

Dionne R, Davis B, Sheeber L, Madrigal L. Initial evaluation of a cultural approach to implementation of evidence-based parenting interventions in American Indian communities. J ournal of Community Psychology 2009;37(7):911-21. [Other: 0090-4392]

\section{Doherty 2006}

Doherty WJ , Erickson MF, LaRossa R. An intervention to increase father involvement and skills with infants during the transition to parenthood. J ournal of Family Psychology 2006;20(3):438-47. [MEDLINE: 230; Other: CN00567663]

\section{Drew 2002}

Drew A, Baird G, Baron-Cohen S, Cox A, Slonims V, Wheelwright S et al. A pilot randomised control trial of a parent training intervention for pre-school children with autism: preliminary findings and methodological challenges. European Child \&Adolescent Psychiatry 2002;11(6):266-72.

\section{Duch 2011}

Duch H, Rodriguez C. Strengthening families in Head Start: The impact of a parent education programme on the emotional well-being of Latino families. Early Child Development and Care 2011;181(6):733-48.

\section{Dumas 2010}

Dumas J , Begle A, French B, Pearl A. Effects of monetary incentives on engagement in the PACE parenting program. J ournal of Clinical Child and Adolescent Psychology 2010;39(3):302-313.

\section{Faircloth 2008}

Faircloth WB, Cummings EM. Evaluating a parent education program for preventing the negative effects of marital conflict. J ournal of Applied Developmental Psychology 2008;29(2):141-56. [MEDLINE: 430; Other: 01933973] 


\section{Feinberg 2008}

Feinberg ME, Kan ML. Establishing family foundations: intervention effects on coparenting, parent/infant wellbeing, and parent-child relations. J ournal of Family Psychology 2008;22(2):253-63.

\section{Feinfield 2004}

Feinfield KA BB. Empirical support for a treatment program for families of young children with externalizing problems. J ournal of Clinical Child and Adolescent Psychology 2004;33(1):182-95. [MEDLINE: 1160; Other: CN00468832]

\section{Florsheim 2007}

Florsheim P, Hall S, Gaskill M, McArthur L, McElligott K. The Young Parenthood Program: a preventive intervention to support positive coparenting among pregnant adolescents and their partners. J ournal of Adolescent Health 2007;40 Suppl 1(2):14. [MEDLINE: 42590; Other: 1054-139x]

\section{Forehand 2011}

Forehand RL, Merchant MJ , Parent J , Long N, Linnea K, Baer J . An examination of a group curriculum for parents of young children with disruptive behavior. Behavior Modification 2011;3:235-51.

\section{Forgatch 1999}

Forgatch MS, DeGarmo DS. Parenting through change: an effective prevention program for single mothers. J ournal of Consulting and Clinical Psychology 1999;67(5):711-24.

\section{Fossum 2009}

Fossum S, Morch WT, Handegard BH, Drugli MB, Larsson B. Parent training for young Norwegian children with ODD and CD problems: predictors and mediators of treatment outcome. Scandinavian J ournal of Psychology 2009;50(2):173-81.

\section{Hahlweg 2010}

Hahlweg K, Heinrichs N, Kuschel A, Bertram H, Naumann S. Long-term outcome of a randomized controlled universal prevention trial through a positive parenting program: is it worth the effort? Child and Adolescent Psychiatry and Mental Health 2010;4:1-14.

\section{Harrison 1997}

Harrison K. Parental training for incarcerated fathers: effects on attitudes, selfesteem, and children's self-perceptions. The J ournal of Social Psychology 1997;137(5):588-93. 


\section{Havighurst 2009}

Havighurst SS, Wilson KR, Harley AE, Prior MR. Tuning in to kids: An emotionfocused parenting program - initial findings from a community trial. J ournal of Community Psychology 2009;37(8):1008-23. [Other: 0090-4392]

\section{Hawkins 2006}

Hawkins AJ , Fawcett EB, Carroll J S, Gilliland TT. The marriage moments program for couples transitioning to parenthood: divergent conclusions from formative and outcome evaluation data. J ournal of Family Psychology 2006;20(4):561-70. [MEDLINE: 38420; Other: 0272-4944]

\section{Hayes 2008}

Hayes L, Matthews J , Copley A, Welsh D. A randomized controlled trial of a mother-infant or toddler parenting program: demonstrating effectiveness in practice. J ournal of Pediatric Psychology 2008;33(5):473-86.

\section{Heinrichs 2010}

Heinrichs N, J ensen-Doss A. The effects of incentives on families' long-term outcome in a parenting program. J ournal of Clinical Child and Adolescent Psychology 2010;39(5):705-12.

\section{Helfenbaum 2007}

Helfenbaum KED, Ortiz C. Parent-training groups for fathers of Head Start Children: a pilot study of their feasibility and impact on child behavior and intrafamilial relationships. Child and Family Behavior Therapy 2007;29(2):47-64. [Other: 0731-7107]

\section{Hoff 2005}

Hoff AL, Mullins LL, Gillaspy SR, Page MC, Van PeltJ C, ChaneyJ M. An intervention to decrease uncertainty and distress among parents of children newly diagnosed with diabetes: a pilot study. Families, Systems, \& Health 2005;23(3):329-42. [MEDLINE: 29400]

\section{Hughes 2004}

Hughes J R, Gottlieb LN. The effects of the Webster-Stratton Parenting Program on maltreating families: fostering strengths. Child Abuse and Neglect 2004;28(10):1081-97. [Other: 0145-2134]

\section{Hutchings 2002}

Hutchings J , Appleton P, Smith M, Lane E, Nash S. Evaluation of two treatments for children with severe behaviour problems: child behaviour and maternal mental health outcomes. Behavioural \& Cognitive Psychotherapy 2002;30(3):279-95. 


\section{Kaaresen 2008}

Kaaresen PI, Ronning J A, Tunby J , Nordhov SM, Ulvund SE, Dahl LB. A randomized controlled trial of an early intervention program in low birth weight children: outcome at 2 years. Early Human Development 2008;84(3):201-9.

[Other: 0378-3782]

\section{Kacir 1999}

Kacir CD, Gordon DA. Parenting adolescents wisely: the effectiveness of an interactive videodisk parent training program in Appalachia. Child \& Family Behavior Therapy 1999;21(4):1-22.

\section{Kalinauskiene 2009}

Kalinauskiene L, Cekuoliene D, Van Ijzendoorn MH, Bakermans-Kranenburg MJ , J uffer F, Kusakovskaja I. Supporting insensitive mothers: the Vilnius randomized control trial of video-feedback intervention to promote maternal sensitivity and infant attachment security. Child: Care, Health \& Development 2009;35(5):613-23. [Other: 0305-1862]

\section{Kazdin 1992}

Kazdin AE, Siegel TC, Bass D. Cognitive problem-solving skills training and parent management training in the treatment of antisocial behavior in children. J ournal of Consulting and Clinical Psychology 1992;60(5):733-47.

\section{Kazdin 2003}

Kazdin AE, Whitley MK. Treatment of parental stress to enhance therapeutic change among children referred for aggressive and antisocial behavior. J ournal of Consulting and Clinical Psychology 2003;71(3):504-15. [MEDLINE: 36310]

\section{Kiebert 2005}

Kiebert BW. The Effect of Parenthood Education on Self-efficacy, Parent Effectiveness, and the Parent-Child Relationship in an Alternative High School Student Population. Hagerman, ID: University of Idaho, 2005. [MEDLINE: 25180]

\section{Kim 2008}

Kim E, Cain KC, Webster-Stratton C. The preliminary effect of a parenting program for Korean American mothers: a randomized controlled experimental study. International J ournal of Nursing Studies 2008;45(9):1261-73.

\section{Lagges 1999}

Lagges AM, Gordon DA. Use of an interactive laserdisc parent training program with teenage parents. Child and Family Behavior Therapy 1999;21(1):19-37. 


\section{Lamb 2007}

Lamb K. Addressing the challenges of parenting: parent training with parents of children with ADHD. Dissertation Abstracts International 2007;67(11). [MEDLINE: 36450; Other: 0419-4209]

\section{Landy 2006}

Landy S, Menna R. An evaluation of a group intervention for parents with aggressive young children: improvements in child functioning, maternal confidence, parenting knowledge and attitudes. Early Child Development and Care 2006;176(6):605-20. [MEDLINE: 26180]

\section{Lavigne 2008}

Lavigne JV, LeBailly SA, Gouze KR, Cicchetti C, Pochyly J , Arend R et al. Treating oppositional defiant disorder in primary care: a comparison of three models. J ournal of Pediatric Psychology 2008;33(5):449-61.

\section{Leung 2003}

Leung C Saunders MR, Leung S, Mak R, Lau J . An outcome evaluation of the implementation of the Triple P-Positive Parenting Program in Hong Kong. Family Process 2003;42(4):531-44. [MEDLINE: 1510; Other: CN-00469519]

\section{$\operatorname{Lim} 2005$}

Lim M, Stormshak EA, Dishion TJ . A one-session intervention for parents of young adolescents: videotape modeling and motivational group discussion. J ournal of Emotional and Behavioral Disorders 2005;13(4):194-9. [MEDLINE: 39300; Other: 1063-4266]

\section{Linares 2006}

Linares LO, Montalto D, Li M, Oza VS. A Promising Parenting Intervention in Foster Care. J ournal of Consulting and Clinical Psychology 2006; 74(1):32-41. [Other: 0022-006X]

\section{Martinez 2001}

Martinez CR, Forgatch MS. Preventing problems with boys' noncompliance: effects of a parent training intervention for divorcing mothers. J ournal of Consulting and Clinical Psychology 2001;69(3):416-28.

\section{Martinez 2005}

Martinez CR J r, Eddy J M. Effects of culturally adapted parent management training on Latino youth behavioral health outcomes. J ournal of Consulting and Clinical Psychology 2005;73(5):841-51. [MEDLINE: 670; Other: CN-00552962] 


\section{Matos 2009}

Matos M, Bauermeister JJ , Bernal G. Parent-child interaction therapy for Puerto Rican preschool children with ADHD and behavior problems: a pilot efficacy study. Family Process 2009;48(2):232-52. [Other: 0014-7370]

\section{Matthey 2004}

Matthey S, Kavanagh DJ , Howie P, Barnett B, Charles M. Prevention of postnatal distress or depression: an evaluation of an intervention at preparation for parenthood classes. J ournal of Affective Disorders 2004;79(1-3):113-26. [MEDLINE: 33080]

\section{McCabe 2009}

McCabe K, Yeh M. Parent-child interaction therapy for Mexican Americans: a randomized clinical trial. J ournal of Clinical Child and Adolescent Psychology 2009;38(5):753-9. [Other: 1537-4416]

\section{McIntyre 2008}

McIntyre LL. Parent training for young children with developmental disabilities: randomized controlled trial. American J ournal of Mental Retardation 2008;113(5):356-68. [PubMed: 18702556]

\section{Melnyk 2007}

Melnyk BM, Crean HF, Feinstein NF, Fairbanks E, Alpert Gillis LJ . Testing the theoretical framework of the COPE program for mothers of critically ill children: an integrative model of young children's post-hospital adjustment behaviors. J ournal of Pediatric Psychology 2007;32(4):463-74. [MEDLINE: 23460]

\section{Mendelsohn 2007}

Mendelsohn AL, Valdez PT, Flynn V, Foley GM, Berkule SB, Tomopoulos S et al. Use of videotaped interactions during pediatric well-child care: Impact at 33 months on parenting and on child development. J ournal of Developmental and Behavioral Pediatrics 2007;28(3):206-12. [MEDLINE: 22770]

\section{Miller-Heyl 1998}

Miller-Heyl J , MacPhee D, FritzJJ . DARE to be You: A family-support, early prevention program. The J ournal of Primary Prevention 1998;18(3):257-85.

\section{Mullin 1994}

Mullin E, Quigley K, Glanville B. A controlled evaluation of the impact of a parent training programme on child behaviour and mothers' general wellbeing. Counselling Psychology Quarterly 1994;7(2):167-79. 


\section{NCT00183365}

NCT00183365. Effect of family-based prevention on children of depressed parents. http:/ / clinicaltrials.gov/ ct2/ show/ NCT00183365. Accessed 21 April 2011.

\section{Nixon 2004}

Nixon RDV, Sweeney L, Erickson DB, Touyz SW. Parent-child interaction therapy: one- and two-year follow-up of standard and abbreviated treatments for oppositional preschoolers. J ournal of Abnormal Child Psychology 2004;32(3):263. [Other: 0091-0627]

\section{Ogden 2008}

Ogden T, Hagen KA. Treatment effectiveness of parent management training in Norway: a randomized controlled trial of children with conduct problems. J ournal of Consulting and Clinical Psychology 2008;76(4):607-21. [Other: 0022006X]

\section{Olivares 1997}

Olivares J , Rosa AI, Garcia-Lopez LJ . Video paper on the training of mothers: a comparative study [El papel del video en el entrenamiento a Madres: un estudio comparativo]. Psicologia Conductual 1997;5(2):237-54.

\section{Openden 2005}

Openden DA. Pivotal Response Treatment for Multiple Families of Children with Autism: Probable Efficacy and Effectiveness of a Group Parent Education Workshop. Santa Barbara, CA: University of California, 2005.

\section{Orrell-Valente 1999}

Orrell-Valente J K, Pinderhughes EE, Valente E, Laird RD. If it's offered, will they come? Influences on parents' participation in a community-based conduct problems prevention program. American J ournal of Community Psychology 1999;27(6):753-83.

\section{Ostergren 2003}

Ostergren CS. Evaluation of a temperament-based parenting program: factors affecting program usefulness, ease of understanding, preferred amount of materials and parental attitudes. Dissertation Abstracts International 2003;64(5):Nov 2003. [MEDLINE: 37690; Other: 0419-4209]

\section{Plant 2007}

Plant KM, Saunders MR. Reducing problem behavior during care-giving in families of preschool-aged children with developmental disabilities. Research in Developmental Disabilities 2007;28(4):362-85. [MEDLINE: 160; Other: CN00608760] 


\section{Rahman 2009}

Rahman A, Iqbal Z, Roberts C, Husain N. Cluster randomized trial of a parentbased intervention to support early development of children in a low-income country. Child: Care, Health \& Development 2009;35(1):56-62. [Other: 03051862]

\section{Rapee 2005}

Rapee RM, Kennedy S, Ingram M, Edwards S, Sweeney L. Prevention and early intervention of anxiety disorders in inhibited preschool children. J ournal of Consulting and Clinical Psychology 2005; 73(3):488-97. [MEDLINE: 10530]

\section{Reid 2001}

Reid MJ , Webster-Stratton C, Beauchaine TP. Parent training in head start: a comparison of program response among African American, Asian American, Caucasian, and Hispanic mothers. Prevention Science 2001;2(4):209-27.

\section{Reid 2004}

Reid MJ , Webster SC, Baydar N. Halting the development of conduct problems in head start children: the effects of parent training. J ournal of Clinical Child and Adolescent Psychology 2004;33(2):279-91. [Other: 1537-4416]

\section{Ruffolo 2005}

Ruffolo MC, Kuhn MT, Evans ME. Support, empowerment, and education: a study of multiple family group psychoeducation. J ournal of Emotional and Behavioral Disorders 2005;13(4):200-12. [MEDLINE: 27990]

\section{Sanders 2000}

Sanders MR, Markie-Dadds C, Tully LA, Bor W. The Triple P-Positive Parenting Program: a comparison of enhanced, standard, and self-directed behavioral family intervention for parents of children with early onset conduct problems. J ournal of Consulting and Clinical Psychology 2000;68(4):624-40.

\section{Sanford 2003}

Sanford M, Byrne C, Williams S, Atley S, Miller J , Allin H. A pilot study of a parent-education group for families affected by depression. Canadian J ournal of Psychiatry 2003;48(2):78-86. [MEDLINE: 1440; Other: CN-00431459]

\section{Sawasdipanich 2010}

Sawasdipanich N, Srisuphan W, Yenbut J , Tiansawad S, Humphreys J . Effects of a cognitive adjustment program for Thai parents. Nursing \&Health Sciences 2010;12(3):306-13. 


\section{Scott 1987}

Scott MJ , Stradling SG. Evaluation of a group programme for parents of problem children. Behavioral Psychotherapy 1987;15(3):224-39.

\section{Scott 2002}

\section{Unpublished data only}

Scott S, Sylva K. The Spokes Project: supporting parents on kids' education.

Department of Health Project Funded by the Parenting Initiative (UK) 2002.

\section{Scott 2005}

Scott S. Do parenting programmes for severe child antisocial behaviour work over the longer term, and for whom? One year follow-up of a multi-centre controlled trial. Behavioural and Cognitive Psychotherapy 2005;33(4):403-21. [MEDLINE: 610; Other: CN-00605903]

\section{Scott 2009}

Scott S, Sylva K, Doolan M, Price J , J acobs B, Crook C et al. Randomised controlled trial of parent groups for child antisocial behaviour targeting multiple risk factors: the SPOKES project. J ournal of Child Psychology and Psychiatry 2010;51(1):48-57. [Other: 0021-9630]

\section{Sheeber 1994}

Sheeber LB, J ohnson J H. Evaluation of a temperament-focused, parent training program. J ournal of Clinical Child Psychology 1994;23(3):249-59.

\section{Shifflett 1999}

Shifflett K, Cummings EM. A program for educating parents about the effects of divorce and conflict on children: an initial evaluation. Family Relations 1999;48(1):79-89.

\section{Singer 1999}

Singer GHS, Marquis J , Powers LK, Blanchard L, Divenere N, Santelli B et al. A multi-site evaluation of parent to parent programs for parents of children with disabilities. J ournal of Early Intervention 1999;22(3):217-29.

\section{Sonuga-Barke 2001}

Sonuga-Barke EJ S, Daley D, Thompson M, Laver-Bradbury C, Weeks A. Parentbased therapies for preschool attention-deficit/ hyperactivity disorder: A randomized, controlled trial with a community sample. J ournal of the American Academy of Child \&Adolescent Psychiatry 2001;40(4):402-8. 


\section{Sonuga-Barke 2002}

Sonuga-Barke EJ , Daley D, Thompson M. Does maternal ADHD reduce the effectiveness of parent training for preschool children's ADHD? J ournal of the American Academy of Child \&Adolescent Psychiatry 2002;41(6):696-702.

\section{St J ames Roberts 2001}

St J ames-Roberts I, Sleep J , Morris S, Owen C, Gillham P. Use of a behavioural programme in the first 3 months to prevent infant crying and sleeping problems. J ournal of Paediatrics and Child Health 2001;37(3):289-97.

\section{Steiman 2005}

Steiman M. Parent training with children with conduct problems: the role of the marital relationship and parental adjustment. Washington, DC: University of Washington, 2005. [MEDLINE: 28770]

\section{Suchman 2004}

Suchman NE, McMahon TJ , Luthar SS. Interpersonal maladjustment as predictor of mothers' response to a relational parenting intervention. J ournal of Substance Abuse Treatment 2004;27(2):135-43. [MEDLINE: 32320]

\section{Suess 2005}

Suess GJ , Kissgen R. STEEP-an attachment- and research-based early intervention program [STEEP-ein bindungstheoretisch und empirisch fundiertes Fruhinterventionsprogramm]. Psychologie-in-Erziehung-und-Unterricht 2005. [MEDLINE: 28810]

\section{Sutton 1992}

Sutton C. Training parents to manage difficult children: a comparison of methods. Behavioural Psychotherapy 1992;20(2):115-39.

\section{Sutton 1995}

Sutton C. Parent training by telephone: a partial replication. Behavioural and Cognitive Psychotherapy 1995;23(1):1-24.

\section{Thompson 2009}

Thompson MJ , Laver-Bradbury C, Ayres M, Le Poidevin E, Mead S, Dodds C et al. A small-scale randomized controlled trial of the revised new forest parenting programme for preschoolers with attention deficit hyperactivity disorder. European Child and Adolescent Psychiatry 2009;18(10):605-16. [Other: 10188827]

\section{Thompson 2010}

Thompson MJ , Ayres M, Le Poidevin E, Mead S, Dodds C. A small-scale randomized controlled trial of the selfhelp version of the new forest parent 
training programme for children with ADHD. European Child and Adolescent Psychiatry 2010;18:605-6.

\section{Thorell 2009}

Thorell LB. The Community Parent Education Program (COPE): treatment effects in a clinical and a community-based sample. Clinical Child Psychology and Psychiatry 2009;14(3):373-87.

\section{Tonge 2006}

Tonge B, Brereton A, Kiomall M, MacKinnon A, King N, Rinehart N. Effects on parental mental health of an education and skills training program for parents of young children with autism: a randomized controlled trial. J ournal of the American Academy of Child and Adolescent Psychiatry 2006;45(5):561-9. [MEDLINE: 290; Other: CN-00564984]

\section{Trost 2007}

Trost AS. The Healthy Image Partnership (HIP) parents program: the role of parental involvement in eating disorder prevention ( $\mathrm{PhD}$ Thesis). Austin, Texas: The University of Texas, 2007. [MEDLINE: 20970]

\section{Turner 2006a}

Turner KMT, Sanders MR. Help when it's needed first: a controlled evaluation of brief, preventive behavioral family intervention in a primary care setting. Behavior Therapy 2006;37(2):131-42.

\section{Uslu 2006}

Uslu R, Kapci EG, Erden G. Psychoeducation and expressed emotion by parents of children with learning disorders. Psychological Reports 2006;98(2):291-306. [MEDLINE: 400; Other: CN-00566051]

\section{Van Wyk 1983}

Van WykJ D, Eloff ME, Heyns PM. The evaluation of an integrated parent training program. The J ournal of Social Psychology 1983;121(2):273-81.

\section{Webster-Stratton 2001}

Webster-Stratton C, Reid MJ , Hammond M. Preventing conduct problems, promoting social competence: a parent and teacher training partnership in Head Start. J ournal of Clinical Child Psychology 2001;30(3):283-302.

\section{Webster-Stratton 2004}

Webster Stratton C, Reid MJ , Hammond M. Treating children with early-onset conduct problems: intervention outcomes for parent, child, and teacher training. J ournal of Clinical Child and Adolescent Psychology 2004;33(1):105-24. [MEDLINE: 1430; Other: CN-00468833] 


\section{Wheatley 2003}

Wheatley SL, Brugha TS, Shapiro DA. Exploring and enhancing engagement to the psychosocial intervention 'Preparing for Parenthood'. Archives of Women's Mental Health 2003;6(4):275-85. [MEDLINE: 33930]

\section{Whitehurst 2008}

Whitehurst DH, O'Keefe SL, Wilson RA. Divorced and separated parents in conflict: results from a true experiment effect of a court mandated parenting education program. J ournal of Divorce and Remarriage 2008;48(3-4):127-44. [MEDLINE: 170; Other: 1050-2556]

\section{Whittingham 2009a}

Whittingham K, Sofronoff K, Sheffield J , Sanders MR. Stepping Stones Triple-P: an RCT of a parenting program with parents of a child diagnosed with an autism spectrum disorder. J ournal of Abnormal Child Psychology 2009;37(4):469-80. [MEDLINE: 310; Other: 0091-0627]

\section{Whittingham 2009b}

Whittingham K, Sofronoff K, Sheffield J , Sanders MR. Do parental attributions affect treatment outcome in a parenting program? An exploration of the effects of parental attributions in an RCT of Stepping Stones Triple-P for the ASD population. Research in Autism Spectrum Disorders 2009;3(1):129-44. [Other: 1750-9467]

\section{Wiggins 2009}

Wiggins TL, Sofronoff K, Sanders MR. Pathways Triple P-Positive Parenting Program: effects on parent-child relationships and child behavior problems. Family Process 2009;48(4):517-30. [Other: 0014-7370]

\section{Wissow 2008}

Wissow LS, Gadomski A, Roter D, Larson S, Brown J , Zachary C et al. Improving child and parent mental health in primary care: A cluster-randomized trial of communication skills training. Pediatrics 2008;121(2):266-75. [Other: 00314005(print); Other: 1098-4275(electronic)]

\section{Wolkchik 1993}

Wolkchik SA, West SG, Westover S, Sandler IN, Martin A, LustigJ et al. The children of divorce parenting intervention: outcome evaluation of an empirically based program. American J ournal of Community Psychology 1993;21(3):293331. 


\section{Zimmerman 1996}

Zimmerman TS, J acobsen RB, MacIntyre M, Watson C. Solution-focused parenting groups: an empirical study. J ournal of Systemic Therapies 1996;15(4):12-25.

\subsection{STUDIES AWAITING CLASSIFICATION}

\section{Bayer 2010}

Bayer J K, Hiscock H, Ukoumunne OC, Scalzo K, Wake M. Three-year-old outcomes of a brief universal parenting intervention to prevent behaviour problems: randomised controlled trial. Archives of Disease in Childhood 2010;95:187-92.

\section{Bywater 2011}

Bywater T, Hutchings J , Linck P, Whitaker C, Daley D, Yeo S, Edwards R. Incredible Years parent training support for foster carers in Wales: a multicentre feasibility study. Child: Care, Health and Development 2011;37(2):23343.

\section{Cefai 2010}

Cefai J , Smith D, Pushak RE. Parenting wisely: parent training via CD-ROM with an Australian sample. Child \& Family Behavior Therapy 2010;32(1):17-33.

\section{Eichelberger 2010}

Eichelberger I, Pluck J , Hanisch C, Hautmann C, J anen N, Dopfner M. Effects of the universal parent training program Triple $\mathrm{P}$ on child behavior problems, parenting strategies, and psychological distress. Zeitschrift fur Klinische Psychologie und Psychotherapie 2010;39(1):24-32.

\section{Franz 2007}

Franz M, Gertheinrichs T, Guttgemanns J , Haubold S, Rentsch D, Schafer R. Palme - a structured attachment oriented parental training for depressive single mothers. First results of a controlled randomized intervention study in an urban community. Psychotherapie Psychosomatik Medizinische Psychologie 2007;57(2):84-5. [MEDLINE: 54510]

\section{Hampel 2010}

Hampel OA, Schaadt AK, Hasmann SE, Petermann F, Holl R, Hasmann R. Evaluation of Stepping Stones Triple P: Interims analysis of the SteppingStones-SPC-Multicentric Study. Klinische Paediatrie 2010;222:18-25. 


\section{Heinrichs 2006}

Heinrichs N Hahlweg K, Bertram H, Kuschel A, Naumann S, Harstick S. The 1year efficacy of a parent training in the universal prevention of child-behavior problems: results from mothers and fathers. Zeitschrift fur Klinische Psychologie und Psychotherapie 2006;35(2):82-96. [MEDLINE: 480; Other: CN-00615242] Heinrichs N, Bertram H, Kuschel A, Hahlweh K. Parent recruitment and retention in a universal prevention program for child behaviour and emotional problems: barriers to research and program participation. Prevention Science 2005;6(4):275-86.

Heinrichs N, Hahlweg K, Naumann S, Kuschel A, Bertram H, Ständer D. Universal prevention of child behaviour problems with parent training programme: outcomes after three years. [Universelle Prävention kindlicherVerhaltensstörungen mithilfeeiner elternzentrierten MaßnahmeErgebnisse drei J ahre nach Teilnahme]. Zeitschrift für Klinische Psychologie und Psychotherapie 2009;38(2):79-88.

\section{Morawska 2011}

Morawska A, Haslam D, Milne D, Sanders MR. Evaluation of a brief parenting discussion group for parents of young children. J ournal of Developmental and Behavioral Pediatrics 2011;2:136-145.

\section{Naumann 2007}

Naumann S, Kuschel A, Bertram H, Heinrichs N, Hahlweg K. Promotion of Parental Competence With Triple P. Praxis Der Kinderpsychologie Und Kinderpsychiatrie 2007;56(8):676-90. [MEDLINE: 49620]

\section{Reedtz 2011}

Reedtz C, Handegård BH, Mørch WT. Promoting positive parenting practices in primary pare: outcomes and mechanisms of change in a randomized controlled risk reduction trial. Scandinavian J ournal of Psychology 2011;2:131-7.

\section{Sanders 2011}

Sanders MR, Stallman HM, McHale M. Workplace Triple P: a controlled evaluation of a parenting intervention for working parents. J ournal of Family Psychology 2011;25(4):581-90.

\subsection{ONGOING STUDIES}

\section{Spijkers W, J ansen D, de Meer G, Reijneveld SA.}

Effectiveness of a parenting programme in a public health setting: a randomised controlled trial of the positive parenting programme (Triple P) level 3 versus care as usual provided by the preventive child healthcare (PCH). BMC Public Health 2010;10:131-7. 


\section{Other references}

\section{1 ADDITIONAL REFERENCES}

\section{Abidin 1983}

Abidin RR. The Parenting Stress Index. Charlottesville, VA: Pediatric Psychology Press, 1983.

\section{Barlow 2010}

Barlow J , Smailagic N, Ferriter M, Bennett C, J ones H. Group-based parent training programmes for improving emotional and behavioural adjustment in children from birth to three years old. Cochrane Database of Systematic Reviews 2010, Issue 3. Art. No.: CD003680. DOI: 10.1002/ 14651858.CD003680.

\section{Barlow 2011}

Barlow J , Smailagic N, Bennett C, Huband N, J ones H, Coren E. Individual and group based parenting programmes for improving psychosocial outcomes for teenage parents and their children. Cochrane Database of Systematic Reviews 2011, Issue 3. Art. No.: CD002964. DOI: 10.1002/ 14651858.CD002964.

\section{Beardslee 1998}

Beardslee W, Versage E, Gladstone T. Children of affectively ill parents: a review of the past 10 years. J ournal of the American Academy of Child and Adolescent Psychiatry 1998;37(11):1134-41.

\section{Beck 1961}

Beck AT, Ward CH, Mendelson M, MockJ , Erbaugh J . An inventory for measuring depression. Archive of General Psychiatry 1961;4(6):561-71.

\section{Beck 1988}

Beck AT, Epstein N, Brown G, Steer RA. An inventory for measuring clinical anxiety: psychometric properties. J ournal of Consulting and Clinical Psychology 1988;56:893-7. 


\section{Beebe 2011}

Beebe B, Steele M, J affe J , Buck KA, Chen H, Cohen P et al. Maternal anxiety symptoms and mother-infant self- and interactive contingency. Infant Mental Health J ournal 2011;32(2):174-206.

\section{Cornish 2008}

Cornish AM, McMahon C, UngererJ A. Postnatal depression and the quality of mother-infant interactions during the second year of life. Australian J ournal of Psychology 2008;60(3):142-51.

\section{Dawson 1997}

Dawson G, Frey K, Panagiotides H, OsterlingJ , HessI D. Infants of depressed mothers exhibit atypical frontal brain activity: a replication and extension of previous findings. J ournal of Child Psychology and Psychiatry 1997;38(2):179-86.

\section{Department of Health 2009}

Shribman S, Billingham K. Healthy Child Programme: Pregnancy and the First Five Years of Life. London: Department of Health, 2009.

\section{Dretze 2005}

Dretzke J , Frew E, Davenport C, BarlowJ , Stewart-Brown S, SandercockJ et al. The effectiveness and cost-effectiveness of parent training/ education programmes for the treatment of conduct disorder, including oppositional defiant disorder, in children. Health Technology Assessment 2005;9(50):1-233.

\section{Fonagy 1997}

Fonagy $\mathrm{P}$, Target $\mathrm{M}$. Attachment and reflective function: their role in selforganization. Development and Psychopathology 1997;9:679-700.

\section{Grienenberger 2005}

Grienenberger J , Kelly K, Slade A. Maternal reflective functioning, mother-infant affective communication and infant attachment: exploring the link between mental states and observed caregiving behavior in the intergenerational transmission of attachment. Attachment and Human Development 2005; 7(3):299-311.

\section{Gunnar 1994}

Gunnar M. Psychoendocrine studies of temperament and stress in early childhood: expanding current models.. In: Bates J , Wachs T, editor(s). Temperament: Individual Differences at the Interface of Biology and Behavior. Washington, DC: American Psychological Association, 2003:131. [Other: ISBN: 978-1-55798-222-3] 


\section{Higgins 2008}

Higgins J PT, Green S, editors. Cochrane Handbook for Systematic Reviews of Interventions Version 5.0.0 [updated February 2008]. The Cochrane Collaboration, 2008. Available from www.cochrane-handbook.org.

\section{J affe 2001}

J affe J , Beebe B, Feldstein S, Crown CL, J asnow MD. Rhythms of dialogue in infancy: coordinated timing in development. Monographs of the Society for Research in Child Development 2001;66(2):1-132.

\section{J ohnston 1989}

J ohnston C, Mash EJ . A measure of parenting satisfaction and efficacy. J ournal of Clinical Child Psychology 1989;18:167-75.

\section{Kane 2003}

Kane G, Wood VA, BarlowJ . Parenting programmes: a systematic review and synthesis of qualitative research. Child: Care, Health and Development 2003;33(6):784-93.

\section{Kane 2004}

Kane P, Garber J . The relations among depression in fathers, children's psychopathology, and father-child conflict: a meta-analysis. Clinical Psychology Review 2004;24(3):339-60.

\section{Klass 1987}

Klass ET. Situational approach to the assessment of guilt: development and validation of a self-report measure. J ournal of Psychopathology and Behavioral Assessment 1987;9:35-48.

\section{Maiuro 1987}

Maiuro RD, Vitaliano PP, Cahn TS. A brief measure for the assessment of anger and aggression. J ournal of Interpersonal Violence 1987;2:166-78.

\section{Martin 2000}

Martin AJ , Linfoot K, Stephenson J . Exploring the cycle of mother-child relations, maternal confidence and children's aggression. Australian J ournal of Psychology 2000;52(1):34-40.

\section{McGuinn 2004}

McGuinn IBL. Adolescents' perceptions of typical inter-parental conflict and quality of parenting: a path to depression and aggression. New Haven, CT: Yale University, 2003. 


\section{McMahon 2006}

McMahon CA, Barnett B, Kowalenko NM, Tennant CC. Maternal attachment state of mind moderates the impact of postnatal depression on infant attachment. J ournal of Child Psychology and Psychiatry 2006;47(7):660-9.

\section{Murray 1992}

Murray L. The Impact of postnatal depression on infant development. J ournal of Child Psychology and Psychiatry 1992;33(3):543-61.

\section{Murray 1996}

Murray L, Fiori-Cowley A, Hooper, Cooper P. The impact of postnatal depression and associated adversity on early mother-infant interactions and later infant outcome. Child Development 1996;67(5):2512-26.

\section{Parry-Langdon 2008}

Parry-Langdon N. Three years on: survey of the development and emotional wellbeing of children and young people. London: Office for National Statistics 2008.

\section{Patterson 1992}

Patterson GR, Reid J B, Dishion TJ . Antisocial Boys. Eugene OR: CastaliaPress, 1992.

\section{Pawlby 2008}

Pawlby S, Sharpe D, Hay D, O'Keane V. Postnatal depression and child outcome at 11 years: the importance of clinical diagnosis. J ournal of Affective Disorders 2008; 107:241-5.

\section{Ramchandani 2008}

Ramchandani PG, O'Connor TG, Heron J , Murray L, Evans J . The effects of pre and postnatal depression in fathers: a natural experiment comparing the effects of exposure to depression on offspring. J ournal of the American Academy of Child and Adolescent Psychiatry 2008;47(4):390-8.

\section{RevMan 2011}

Review Manager (RevMan) [Computer program]. Version 5.1. Copenhagen: The Nordic Cochrane Centre, The Cochrane Collaboration, 2011.

\section{Rosenberg 1965}

Rosenberg M. Society and the Adolescent Self-Image. Princeton, NJ : Princeton University Press, 1965. 


\section{Schore 2005}

Schore AN. Back to basics: attachment, affect regulation, and the developing right brain: linking developmental neuroscience to pediatrics. Pediatrics in Review 2005;26(6):204-17.

\section{Sharp 1995}

Sharp D, Hay DF, Pawlby S, Schmücker G, Allen H, Kumar R. The impact of postnatal depression on boys' intellectual development. J ournal of Child Psychology and Psychiatry 1995;36(8):1315-36.

\section{Shelton 2008}

Shelton $\mathrm{K}$, Harold $\mathrm{H}$, Gordon T. Interparental conflict, negative parenting, and children's adjustment: bridging links between parents' depression and children's psychological distress. J ournal of Family Psychology 2008;22(5):712-24.

\section{Spanier 1976}

Spanier GB. Measuring dyadic adjustment: new scales for assessing the quality of marriage and similar dyads. J ournal of Marriage and the Family 1976;38:15-28.

\section{Todres 1993}

Todres R, Bunston T. Parent-education programme evaluation: a review of the literature. Canadian J ournal of Community Mental Health 1993;12(1):225-57.

\section{Van IJ zendoorn 1995}

Van IJ zendoorn. Adult attachment representations, parental responsiveness, and infant attachment: a meta-analysis on the predictive validity of the adult attachment interview. Psychological Bulletin 1995;117(3):387-403.

\section{Waylen 2010}

Waylen A, Stewart-Brown S. Factors influencing parenting in early childhood: A prospective longitudinal study focusing on change. Child: Care, Health and Development 2010;36:198-207.

\section{Wilson 2010}

Wilson SB, Durbin CE. Effects of paternal depression on fathers parenting behaviors: a meta-analytic review. Clinical Psychology Review 2010;30(2):167-80. 


\subsection{OTHER PUBLISHED VERSIONS OF THIS REVIEW}

\section{Barlow 2001}

Barlow , Coren E. Parent-training programmes for improving maternal psychosocial health. Cochrane Database of Systematic Reviews 2001, Issue 2. Art. No.: CD002020. DOI: 10.1002/ 14651858.CD002020.

\section{Barlow 2003}

BarlowJ , Coren E, Stewart-Brown S. Parent-training programmes for improving maternal psychosocial health. Cochrane Database of Systematic Reviews 2003, Issue 4. Art. No.: CD002020. DOI: 10.1002/ 14651858.CD002020.pub2. 


\section{Data and analyses}

\subsection{META ANALYSIS: ANY PARENT TRAINING PROGRAMME VERSUS CONTROL (PARENTAL OUTCOMES)}

\begin{tabular}{|c|c|c|c|c|}
\hline Outcome or Subgroup & Studies & Participants & Statistical Method & Effect Estimate \\
\hline 1.1 Depressive symptoms & 27 & & $\begin{array}{l}\text { Std. Mean Difference (IV, } \\
\text { Random, 95\% CI) }\end{array}$ & Subtotals only \\
\hline $\begin{array}{l}\text { 1.1.1 Post intervention } \\
\text { (immediate post intervention } \\
\text { up to four weeks post } \\
\text { intervention) }\end{array}$ & 22 & 1591 & $\begin{array}{l}\text { Std. Mean Difference (IV, } \\
\text { Random, 95\% CI) }\end{array}$ & $-0.17[-0.28,-0.07]$ \\
\hline $\begin{array}{l}\text { 1.1.2 Short term follow up } \\
\text { (one to six months post } \\
\text { intervention) }\end{array}$ & 13 & 2104 & $\begin{array}{l}\text { Std. Mean Difference (IV, } \\
\text { Random, 95\% CI) }\end{array}$ & $-0.10[-0.22,0.03]$ \\
\hline $\begin{array}{l}\text { 1.1.3 Long term follow up } \\
\text { (more than six months post } \\
\text { intervention) }\end{array}$ & 7 & 1491 & $\begin{array}{l}\text { Std. Mean Difference (IV, } \\
\text { Random, 95\% CI) }\end{array}$ & $0.02[-0.10,0.13]$ \\
\hline 1.2 Anxiety symptoms & 11 & & $\begin{array}{l}\text { Std. Mean Difference (IV, } \\
\text { Random, 95\% CI) }\end{array}$ & Subtotals only \\
\hline $\begin{array}{l}\text { 1.2.1 Post intervention } \\
\text { (immediate post intervention } \\
\text { up to four weeks post } \\
\text { intervention) }\end{array}$ & 9 & 464 & $\begin{array}{l}\text { Std. Mean Difference (IV, } \\
\text { Random, 95\% CI) }\end{array}$ & $-0.22[-0.43,-0.01]$ \\
\hline $\begin{array}{l}\text { 1.2.2 Short term follow up } \\
\text { (one to six months post } \\
\text { intervention) }\end{array}$ & 3 & 882 & $\begin{array}{l}\text { Std. Mean Difference (IV, } \\
\text { Random, 95\% CI) }\end{array}$ & $0.05[-0.08,0.19]$ \\
\hline $\begin{array}{l}\text { 1.2.3 Long term follow up } \\
\text { (more than six months post } \\
\text { intervention) }\end{array}$ & 2 & 739 & $\begin{array}{l}\text { Std. Mean Difference (IV, } \\
\text { Random, 95\% CI) }\end{array}$ & $0.02[-0.13,0.16]$ \\
\hline 1.3 Stress & 29 & & $\begin{array}{l}\text { Std. Mean Difference (IV, } \\
\text { Random, } 95 \% \mathrm{CI} \text { ) }\end{array}$ & Subtotals only \\
\hline
\end{tabular}




\begin{tabular}{|c|c|c|c|c|}
\hline Outcome or Subgroup & Studies & Participants & Statistical Method & Effect Estimate \\
\hline $\begin{array}{l}\text { 1.3.1 Post intervention } \\
\text { (immediate post intervention } \\
\text { up to four weeks post } \\
\text { intervention) }\end{array}$ & 25 & 1567 & $\begin{array}{l}\text { Std. Mean Difference (IV, } \\
\text { Random, 95\% Cl) }\end{array}$ & $-0.29[-0.42,-0.15]$ \\
\hline $\begin{array}{l}\text { 1.3.2 Short term follow up } \\
\text { (one to six months post } \\
\text { intervention) }\end{array}$ & 12 & 1680 & $\begin{array}{l}\text { Std. Mean Difference (IV, } \\
\text { Random, 95\% Cl) }\end{array}$ & $-0.22[-0.42,-0.01]$ \\
\hline $\begin{array}{l}\text { 1.3.3 Long term follow up } \\
\text { (more than six months post } \\
\text { intervention) }\end{array}$ & 4 & 1121 & $\begin{array}{l}\text { Std. Mean Difference (IV, } \\
\text { Random, 95\% Cl) }\end{array}$ & $0.02[-0.10,0.13]$ \\
\hline 1.4 Self esteem & 3 & & $\begin{array}{l}\text { Std. Mean Difference (IV, } \\
\text { Random, 95\% CI) }\end{array}$ & Subtotals only \\
\hline $\begin{array}{l}\text { 1.4.1 Post intervention } \\
\text { (immediate post intervention } \\
\text { up to four weeks post } \\
\text { intervention) }\end{array}$ & 2 & 147 & $\begin{array}{l}\text { Std. Mean Difference (IV, } \\
\text { Random, 95\% Cl) }\end{array}$ & $-0.01[-0.45,0.42]$ \\
\hline $\begin{array}{l}\text { 1.4.2 Short term follow up } \\
\text { (one to six months post } \\
\text { intervention) }\end{array}$ & 2 & 193 & $\begin{array}{l}\text { Std. Mean Difference (IV, } \\
\text { Random, 95\% Cl) }\end{array}$ & $0.06[-0.22,0.34]$ \\
\hline $\begin{array}{l}\text { 1.4.3 Long term follow up } \\
\text { (more than six months post } \\
\text { intervention) }\end{array}$ & 2 & 168 & $\begin{array}{l}\text { Std. Mean Difference (IV, } \\
\text { Random, 95\% CI) }\end{array}$ & $0.10[-0.21,0.40]$ \\
\hline 1.5 Anger & 3 & & $\begin{array}{l}\text { Std. Mean Difference (IV, } \\
\text { Random, 95\% Cl) }\end{array}$ & Subtotals only \\
\hline $\begin{array}{l}\text { 1.5.1 Post intervention } \\
\text { (immediate post intervention } \\
\text { up to four weeks post } \\
\text { intervention) }\end{array}$ & 3 & 107 & $\begin{array}{l}\text { Std. Mean Difference (IV, } \\
\text { Random, 95\% CI) }\end{array}$ & $-0.60[-1.00,-0.20]$ \\
\hline 1.6 Guilt & 3 & & $\begin{array}{l}\text { Std. Mean Difference (IV, } \\
\text { Random, 95\% Cl) }\end{array}$ & Subtotals only \\
\hline $\begin{array}{l}\text { 1.6.1 Post intervention } \\
\text { (immediate post intervention } \\
\text { up to four weeks post } \\
\text { intervention) }\end{array}$ & 3 & 119 & $\begin{array}{l}\text { Std. Mean Difference (IV, } \\
\text { Random, 95\% Cl) }\end{array}$ & $-0.79[-1.18,-0.41]$ \\
\hline 1.7 Confidence & 15 & & $\begin{array}{l}\text { Std. Mean Difference (IV, } \\
\text { Random, 95\% CI) }\end{array}$ & Subtotals only \\
\hline 1.7.1 Post intervention & 14 & 1001 & Std. Mean Difference (IV, & $-0.34[-0.51,-0.17]$ \\
\hline
\end{tabular}




\begin{tabular}{|c|c|c|c|c|}
\hline Outcome or Subgroup & Studies & Participants & Statistical Method & Effect Estimate \\
\hline $\begin{array}{l}\text { (immediate post intervention } \\
\text { up to four weeks post } \\
\text { intervention) }\end{array}$ & & & Random, 95\% Cl) & \\
\hline $\begin{array}{l}\text { 1.7.2 Short term follow up } \\
\text { (one to six months post } \\
\text { intervention) }\end{array}$ & 7 & 636 & $\begin{array}{l}\text { Std. Mean Difference (IV, } \\
\text { Random, 95\% Cl) }\end{array}$ & $-0.32[-0.63,-0.01]$ \\
\hline $\begin{array}{l}\text { 1.7.3 Long term follow up } \\
\text { (more than six months post } \\
\text { intervention) }\end{array}$ & 2 & 381 & $\begin{array}{l}\text { Std. Mean Difference (IV, } \\
\text { Random, 95\% Cl) }\end{array}$ & $-0.39[-1.16,0.38]$ \\
\hline 1.8 Partner satisfaction & 9 & & $\begin{array}{l}\text { Std. Mean Difference (IV, } \\
\text { Random, 95\% Cl) }\end{array}$ & Subtotals only \\
\hline $\begin{array}{l}\text { 1.8.1 Post intervention } \\
\text { (immediate post intervention } \\
\text { up to four weeks post } \\
\text { intervention) }\end{array}$ & 9 & 432 & $\begin{array}{l}\text { Std. Mean Difference (IV, } \\
\text { Random, 95\% Cl) }\end{array}$ & $-0.28[-0.47,-0.09]$ \\
\hline $\begin{array}{l}\text { 1.8.2 Short term follow up } \\
\text { (one to six months post } \\
\text { intervention) }\end{array}$ & 1 & 46 & $\begin{array}{l}\text { Std. Mean Difference (IV, } \\
\text { Random, 95\% Cl) }\end{array}$ & $-0.33[-0.91,0.25]$ \\
\hline
\end{tabular}




\subsection{APPENDIX TO DATA AND ANALYSES SECTION, RESULTS FROM INDIVIDUAL STUDIES (NO META-ANALYSIS): ANY PARENT TRAINING PROGRAMME VERSUS CONTROL}

\begin{tabular}{|c|c|c|c|c|}
\hline Outcome or Subgroup & Studies & Participants & Statistical Method & Effect Estimate \\
\hline $\begin{array}{l}\text { 2.1 Parental outcomes: } \\
\text { depressive symptoms } \\
\text { (Beck Depression } \\
\text { Inventory) }\end{array}$ & 9 & & $\begin{array}{l}\text { Std. Mean Difference (IV, } \\
\text { Fixed, } 95 \% \mathrm{Cl} \text { ) }\end{array}$ & No totals \\
\hline $\begin{array}{l}\text { 2.1.1 Post intervention } \\
\text { (immediate post } \\
\text { intervention up to four } \\
\text { weeks post intervention) }\end{array}$ & 8 & & $\begin{array}{l}\text { Std. Mean Difference (IV, } \\
\text { Fixed, } 95 \% \mathrm{Cl} \text { ) }\end{array}$ & No totals \\
\hline $\begin{array}{l}\text { 2.1.2 Short term follow up } \\
\text { (one to six months post } \\
\text { intervention) }\end{array}$ & 3 & & $\begin{array}{l}\text { Std. Mean Difference (IV, } \\
\text { Fixed, } 95 \% \mathrm{Cl} \text { ) }\end{array}$ & No totals \\
\hline $\begin{array}{l}\text { 2.1.3 Long term follow up } \\
\text { (more than six months } \\
\text { post intervention) }\end{array}$ & 1 & & $\begin{array}{l}\text { Std. Mean Difference (IV, } \\
\text { Fixed, } 95 \% \mathrm{Cl} \text { ) }\end{array}$ & No totals \\
\hline $\begin{array}{l}\text { 2.2 Parental outcomes: } \\
\text { depressive symptoms } \\
\text { (subscale of Irritability } \\
\text { Depression \& Anxiety } \\
\text { Scale) }\end{array}$ & 0 & & $\begin{array}{l}\text { Std. Mean Difference (IV, } \\
\text { Fixed, } 95 \% \mathrm{Cl} \text { ) }\end{array}$ & No totals \\
\hline $\begin{array}{l}\text { 2.2.1 Post intervention } \\
\text { (immediate post } \\
\text { intervention up to four } \\
\text { weeks post intervention) }\end{array}$ & 0 & & $\begin{array}{l}\text { Std. Mean Difference (IV, } \\
\text { Fixed, } 95 \% \mathrm{Cl} \text { ) }\end{array}$ & No totals \\
\hline $\begin{array}{l}\text { 2.3 Parental outcomes: } \\
\text { depressive symptoms } \\
\text { (subscale of Depression } \\
\text { Anxiety Stress Scale) }\end{array}$ & 8 & & $\begin{array}{l}\text { Std. Mean Difference (IV, } \\
\text { Fixed, } 95 \% \mathrm{Cl} \text { ) }\end{array}$ & No totals \\
\hline $\begin{array}{l}\text { 2.3.1 Post intervention } \\
\text { (immediate post } \\
\text { intervention up to four } \\
\text { weeks post intervention) }\end{array}$ & 6 & & $\begin{array}{l}\text { Std. Mean Difference (IV, } \\
\text { Fixed, } 95 \% \mathrm{Cl} \text { ) }\end{array}$ & No totals \\
\hline $\begin{array}{l}\text { 2.3.2 Short term follow up } \\
\text { (one to six months post } \\
\text { intervention) }\end{array}$ & 2 & & $\begin{array}{l}\text { Std. Mean Difference (IV, } \\
\text { Fixed, } 95 \% \mathrm{Cl} \text { ) }\end{array}$ & No totals \\
\hline $\begin{array}{l}\text { 2.3.3 Long term follow up } \\
\text { (more than six months } \\
\text { post intervention) }\end{array}$ & 1 & & $\begin{array}{l}\text { Std. Mean Difference (IV, } \\
\text { Fixed, } 95 \% \mathrm{Cl} \text { ) }\end{array}$ & No totals \\
\hline
\end{tabular}




\begin{tabular}{|c|c|c|c|c|}
\hline Outcome or Subgroup & Studies & Participants & Statistical Method & Effect Estimate \\
\hline $\begin{array}{l}\text { 2.4 Parental outcomes: } \\
\text { depressive symptoms } \\
\text { (Centre for Epidem. } \\
\text { Studies Depression Scale) }\end{array}$ & 6 & & $\begin{array}{l}\text { Std. Mean Difference (IV, } \\
\text { Fixed, } 95 \% \mathrm{Cl} \text { ) }\end{array}$ & No totals \\
\hline $\begin{array}{l}\text { 2.4.1 Post intervention } \\
\text { (immediate post } \\
\text { intervention up to four } \\
\text { weeks post intervention) }\end{array}$ & 4 & & $\begin{array}{l}\text { Std. Mean Difference (IV, } \\
\text { Fixed, } 95 \% \mathrm{Cl} \text { ) }\end{array}$ & No totals \\
\hline $\begin{array}{l}\text { 2.4.2 Short term follow up } \\
\text { (one to six months post } \\
\text { intervention) }\end{array}$ & 6 & & $\begin{array}{l}\text { Std. Mean Difference (IV, } \\
\text { Fixed, } 95 \% \mathrm{Cl} \text { ) }\end{array}$ & No totals \\
\hline $\begin{array}{l}\text { 2.4.3 Long term follow up } \\
\text { (more than six months } \\
\text { post intervention) }\end{array}$ & 4 & & $\begin{array}{l}\text { Std. Mean Difference (IV, } \\
\text { Fixed, } 95 \% \mathrm{Cl} \text { ) }\end{array}$ & No totals \\
\hline $\begin{array}{l}\text { 2.5 Parental outcomes: } \\
\text { depressive symptoms } \\
\text { (subscale of Parenting } \\
\text { Stress Index) }\end{array}$ & 3 & & $\begin{array}{l}\text { Std. Mean Difference (IV, } \\
\text { Fixed, } 95 \% \mathrm{Cl} \text { ) }\end{array}$ & No totals \\
\hline $\begin{array}{l}\text { 2.5.1 Post intervention } \\
\text { (immediate post } \\
\text { intervention up to four } \\
\text { weeks post intervention) }\end{array}$ & 3 & & $\begin{array}{l}\text { Std. Mean Difference (IV, } \\
\text { Fixed, } 95 \% \mathrm{Cl} \text { ) }\end{array}$ & No totals \\
\hline $\begin{array}{l}\text { 2.5.2 Short term follow up } \\
\text { (one to six months post } \\
\text { intervention) }\end{array}$ & 1 & & $\begin{array}{l}\text { Std. Mean Difference (IV, } \\
\text { Fixed, } 95 \% \mathrm{Cl} \text { ) }\end{array}$ & No totals \\
\hline $\begin{array}{l}\text { 2.6 Parental outcomes: } \\
\text { depressive symptoms } \\
\text { (subscale of General } \\
\text { Health Questionnaire) } \\
\end{array}$ & 1 & & $\begin{array}{l}\text { Std. Mean Difference (IV, } \\
\text { Fixed, } 95 \% \mathrm{Cl} \text { ) }\end{array}$ & No totals \\
\hline $\begin{array}{l}\text { 2.6.1 Post intervention } \\
\text { (immediate post } \\
\text { intervention up to four } \\
\text { weeks post intervention) }\end{array}$ & 1 & & $\begin{array}{l}\text { Std. Mean Difference (IV, } \\
\text { Fixed, } 95 \% \mathrm{Cl} \text { ) }\end{array}$ & No totals \\
\hline $\begin{array}{l}\text { 2.6.2 Short term follow up } \\
\text { (one to six months post } \\
\text { intervention) }\end{array}$ & 1 & & $\begin{array}{l}\text { Std. Mean Difference (IV, } \\
\text { Fixed, } 95 \% \mathrm{Cl} \text { ) }\end{array}$ & No totals \\
\hline $\begin{array}{l}\text { 2.6.3 Long term follow up } \\
\text { (more than six months } \\
\text { post intervention) }\end{array}$ & 1 & & $\begin{array}{l}\text { Std. Mean Difference (IV, } \\
\text { Fixed, } 95 \% \mathrm{Cl} \text { ) }\end{array}$ & No totals \\
\hline $\begin{array}{l}\text { 2.7 Parental outcomes: } \\
\text { anxiety symptoms } \\
\text { (subscale of Depression } \\
\text { Anxiety Stress Scale) } \\
\end{array}$ & 7 & & $\begin{array}{l}\text { Std. Mean Difference (IV, } \\
\text { Fixed, } 95 \% \mathrm{Cl} \text { ) }\end{array}$ & No totals \\
\hline
\end{tabular}




\begin{tabular}{|c|c|c|c|c|}
\hline Outcome or Subgroup & Studies & Participants & Statistical Method & Effect Estimate \\
\hline $\begin{array}{l}\text { 2.7.1 Post intervention } \\
\text { (immediate post } \\
\text { intervention up to four } \\
\text { weeks post intervention) }\end{array}$ & 5 & & $\begin{array}{l}\text { Std. Mean Difference (IV, } \\
\text { Fixed, } 95 \% \mathrm{CI} \text { ) }\end{array}$ & No totals \\
\hline $\begin{array}{l}\text { 2.7.2 Short term follow up } \\
\text { (one to six months post } \\
\text { intervention) }\end{array}$ & 2 & & $\begin{array}{l}\text { Std. Mean Difference (IV, } \\
\text { Fixed, } 95 \% \mathrm{Cl} \text { ) }\end{array}$ & No totals \\
\hline $\begin{array}{l}\text { 2.7.3 Long term follow up } \\
\text { (more than six months } \\
\text { post intervention) }\end{array}$ & 1 & & $\begin{array}{l}\text { Std. Mean Difference (IV, } \\
\text { Fixed, } 95 \% \mathrm{CI} \text { ) }\end{array}$ & No totals \\
\hline $\begin{array}{l}\text { 2.8 Parental outcomes: } \\
\text { anxiety symptoms } \\
\text { (subscale of Irritability, } \\
\text { Depression and Anxiety } \\
\text { Scale) }\end{array}$ & 0 & & $\begin{array}{l}\text { Std. Mean Difference (IV, } \\
\text { Fixed, } 95 \% \mathrm{Cl} \text { ) }\end{array}$ & No totals \\
\hline $\begin{array}{l}\text { 2.8.1 Post intervention } \\
\text { (immediate post } \\
\text { intervention up to four } \\
\text { weeks post intervention) }\end{array}$ & 0 & & $\begin{array}{l}\text { Std. Mean Difference (IV, } \\
\text { Fixed, } 95 \% \mathrm{CI} \text { ) }\end{array}$ & No totals \\
\hline $\begin{array}{l}\text { 2.9 Parental outcomes: } \\
\text { anxiety symptoms } \\
\text { (subscale of General } \\
\text { Health Questionnaire) }\end{array}$ & 1 & & $\begin{array}{l}\text { Std. Mean Difference (IV, } \\
\text { Fixed, } 95 \% \mathrm{Cl} \text { ) }\end{array}$ & No totals \\
\hline $\begin{array}{l}\text { 2.9.1 Post intervention } \\
\text { (immediate post } \\
\text { intervention up to four } \\
\text { weeks post intervention) }\end{array}$ & 1 & & $\begin{array}{l}\text { Std. Mean Difference (IV, } \\
\text { Fixed, } 95 \% \mathrm{Cl} \text { ) }\end{array}$ & No totals \\
\hline $\begin{array}{l}\text { 2.9.2 Short term follow up } \\
\text { (one to six months post } \\
\text { intervention) }\end{array}$ & 1 & & $\begin{array}{l}\text { Std. Mean Difference (IV, } \\
\text { Fixed, } 95 \% \mathrm{Cl} \text { ) }\end{array}$ & No totals \\
\hline $\begin{array}{l}\text { 2.9.3 Long term follow up } \\
\text { (more than six months } \\
\text { post intervention) }\end{array}$ & 1 & & $\begin{array}{l}\text { Std. Mean Difference (IV, } \\
\text { Fixed, } 95 \% \mathrm{Cl} \text { ) }\end{array}$ & No totals \\
\hline $\begin{array}{l}\text { 2.10 Parental outcomes: } \\
\text { anxiety symptoms (STAI } \\
\text { State scale) }\end{array}$ & 1 & & $\begin{array}{l}\text { Std. Mean Difference (IV, } \\
\text { Fixed, } 95 \% \mathrm{Cl} \text { ) }\end{array}$ & No totals \\
\hline $\begin{array}{l}\text { 2.10.1 Post intervention } \\
\text { (immediate post } \\
\text { intervention up to four } \\
\text { weeks post intervention) }\end{array}$ & 1 & & $\begin{array}{l}\text { Std. Mean Difference (IV, } \\
\text { Fixed, } 95 \% \mathrm{Cl} \text { ) }\end{array}$ & No totals \\
\hline $\begin{array}{l}\text { 2.11 Parental outcomes: } \\
\text { anxiety symptoms (STAl } \\
\text { Trait scale) }\end{array}$ & 0 & & $\begin{array}{l}\text { Std. Mean Difference (IV, } \\
\text { Fixed, } 95 \% \mathrm{Cl} \text { ) }\end{array}$ & No totals \\
\hline
\end{tabular}




\begin{tabular}{|c|c|c|c|c|}
\hline Outcome or Subgroup & Studies & Participants & Statistical Method & Effect Estimate \\
\hline $\begin{array}{l}\text { 2.11.1 Post intervention } \\
\text { (immediate post } \\
\text { intervention up to four } \\
\text { weeks post intervention) }\end{array}$ & 0 & & $\begin{array}{l}\text { Std. Mean Difference (IV, } \\
\text { Fixed, } 95 \% \mathrm{CI} \text { ) }\end{array}$ & No totals \\
\hline $\begin{array}{l}\text { 2.11.2 Short term follow } \\
\text { up (one to six months post } \\
\text { intervention) }\end{array}$ & 0 & & $\begin{array}{l}\text { Std. Mean Difference (IV, } \\
\text { Fixed, } 95 \% \mathrm{CI} \text { ) }\end{array}$ & No totals \\
\hline $\begin{array}{l}\text { 2.12 Parental outcomes: } \\
\text { anxiety symptoms (Beck } \\
\text { Anxiety Inventory) }\end{array}$ & 1 & & $\begin{array}{l}\text { Std. Mean Difference (IV, } \\
\text { Fixed, } 95 \% \mathrm{CI} \text { ) }\end{array}$ & No totals \\
\hline $\begin{array}{l}\text { 2.12.1 Post intervention } \\
\text { (immediate post } \\
\text { intervention up to four } \\
\text { weeks post intervention) }\end{array}$ & 1 & & $\begin{array}{l}\text { Std. Mean Difference (IV, } \\
\text { Fixed, } 95 \% \mathrm{Cl} \text { ) }\end{array}$ & No totals \\
\hline $\begin{array}{l}\text { 2.13 Parental outcomes: } \\
\text { anxiety symptoms (Brief } \\
\text { Symptom Inventory) }\end{array}$ & 1 & & $\begin{array}{l}\text { Std. Mean Difference (IV, } \\
\text { Fixed, } 95 \% \mathrm{Cl} \text { ) }\end{array}$ & No totals \\
\hline $\begin{array}{l}\text { 2.13.1 Post intervention } \\
\text { (immediate post } \\
\text { intervention up to four } \\
\text { weeks post intervention) }\end{array}$ & 1 & & $\begin{array}{l}\text { Std. Mean Difference (IV, } \\
\text { Fixed, } 95 \% \mathrm{Cl} \text { ) }\end{array}$ & No totals \\
\hline $\begin{array}{l}\text { 2.14 Parental outcomes: } \\
\text { stress (Perceived Stress } \\
\text { Scale) }\end{array}$ & 1 & & $\begin{array}{l}\text { Std. Mean Difference (IV, } \\
\text { Fixed, 95\% CI) }\end{array}$ & No totals \\
\hline $\begin{array}{l}\text { 2.14.1 Post intervention } \\
\text { (immediate post } \\
\text { intervention up to four } \\
\text { weeks post intervention) }\end{array}$ & 1 & & $\begin{array}{l}\text { Std. Mean Difference (IV, } \\
\text { Fixed, } 95 \% \mathrm{Cl} \text { ) }\end{array}$ & No totals \\
\hline $\begin{array}{l}\text { 2.15 Parental outcomes: } \\
\text { stress (Parenting Stress } \\
\text { Index: overall score) }\end{array}$ & 3 & & $\begin{array}{l}\text { Std. Mean Difference (IV, } \\
\text { Fixed, 95\% CI) }\end{array}$ & No totals \\
\hline $\begin{array}{l}\text { 2.15.1 Post intervention } \\
\text { (immediate post } \\
\text { intervention up to four } \\
\text { weeks post intervention) }\end{array}$ & 3 & & $\begin{array}{l}\text { Std. Mean Difference (IV, } \\
\text { Fixed, 95\% CI) }\end{array}$ & No totals \\
\hline $\begin{array}{l}\text { 2.15.2 Short term follow } \\
\text { up (one to six months post } \\
\text { intervention) }\end{array}$ & 1 & & $\begin{array}{l}\text { Std. Mean Difference (IV, } \\
\text { Fixed, } 95 \% \mathrm{Cl} \text { ) }\end{array}$ & No totals \\
\hline $\begin{array}{l}\text { 2.15.3 Long term follow } \\
\text { up (more than six months } \\
\text { post intervention) }\end{array}$ & 1 & & $\begin{array}{l}\text { Std. Mean Difference (IV, } \\
\text { Fixed, 95\% Cl) }\end{array}$ & No totals \\
\hline $\begin{array}{l}\text { 2.16 Parental outcomes: } \\
\text { stress (Parenting Stress }\end{array}$ & 6 & & $\begin{array}{l}\text { Std. Mean Difference (IV, } \\
\text { Fixed, } 95 \% \mathrm{CI})\end{array}$ & No totals \\
\hline
\end{tabular}




\begin{tabular}{|c|c|c|c|c|}
\hline Outcome or Subgroup & Studies & Participants & Statistical Method & Effect Estimate \\
\hline \multicolumn{5}{|l|}{ Index: parent domain } \\
\hline $\begin{array}{l}\text { 2.16.1 Post intervention } \\
\text { (immediate post } \\
\text { intervention up to four } \\
\text { weeks post interven }\end{array}$ & 6 & & $\begin{array}{l}\text { Std. Mean Difference (IV, } \\
\text { Fixed, } 95 \% \mathrm{Cl} \text { ) }\end{array}$ & No totals \\
\hline $\begin{array}{l}\text { 2.16.2 Short term follow } \\
\text { up (one to six months post } \\
\text { intervention) }\end{array}$ & 2 & & $\begin{array}{l}\text { Std. Mean Difference (IV, } \\
\text { Fixed, } 95 \% \mathrm{CI} \text { ) }\end{array}$ & No totals \\
\hline $\begin{array}{l}\text { 2.17 Parental outcomes: } \\
\text { stress (Parenting Stress } \\
\text { Index - short form: overall } \\
\text { score) }\end{array}$ & 4 & & $\begin{array}{l}\text { Std. Mean Difference (IV, } \\
\text { Fixed, } 95 \% \mathrm{Cl} \text { ) }\end{array}$ & No totals \\
\hline $\begin{array}{l}\text { 2.17.1 Post intervention } \\
\text { (immediate post } \\
\text { intervention up to four } \\
\text { weeks post intervention) }\end{array}$ & 3 & & $\begin{array}{l}\text { Std. Mean Difference (IV, } \\
\text { Fixed, } 95 \% \mathrm{Cl} \text { ) }\end{array}$ & No totals \\
\hline $\begin{array}{l}\text { 2.17.2 Short term follow } \\
\text { up (one to six months post } \\
\text { intervention) }\end{array}$ & 3 & & $\begin{array}{l}\text { Std. Mean Difference (IV, } \\
\text { Fixed, } 95 \% \mathrm{Cl} \text { ) }\end{array}$ & No totals \\
\hline $\begin{array}{l}\text { 2.18 Parental outcomes: } \\
\text { stress (Parenting Stress } \\
\text { Index - short form: distress } \\
\text { subscale) }\end{array}$ & 1 & & $\begin{array}{l}\text { Mean Difference (IV, Fixed, } \\
95 \% \mathrm{Cl})\end{array}$ & No totals \\
\hline $\begin{array}{l}\text { 2.18.1 Post intervention } \\
\text { (immediate post } \\
\text { intervention up to four } \\
\text { weeks post intervention) }\end{array}$ & 1 & & $\begin{array}{l}\text { Mean Difference (IV, Fixed, } \\
95 \% \mathrm{Cl})\end{array}$ & No totals \\
\hline $\begin{array}{l}\text { 2.19 Parental outcomes: } \\
\text { stress (Everyday Stress } \\
\text { Index) }\end{array}$ & 2 & & $\begin{array}{l}\text { Std. Mean Difference (IV, } \\
\text { Fixed, 95\% CI) }\end{array}$ & No totals \\
\hline $\begin{array}{l}\text { 2.19.1 Post intervention } \\
\text { (immediate post } \\
\text { intervention up to four } \\
\text { weeks post intervention) }\end{array}$ & 2 & & $\begin{array}{l}\text { Std. Mean Difference (IV, } \\
\text { Fixed, } 95 \% \mathrm{Cl} \text { ) }\end{array}$ & No totals \\
\hline $\begin{array}{l}\text { 2.19.2 Short term follow } \\
\text { up (one to six months post } \\
\text { intervention) }\end{array}$ & 2 & & $\begin{array}{l}\text { Std. Mean Difference (IV, } \\
\text { Fixed, } 95 \% \mathrm{Cl} \text { ) }\end{array}$ & No totals \\
\hline $\begin{array}{l}\text { 2.19.3 Long term follow } \\
\text { up (more than six months } \\
\text { post intervention) }\end{array}$ & 2 & & $\begin{array}{l}\text { Std. Mean Difference (IV, } \\
\text { Fixed, 95\% CI) }\end{array}$ & No totals \\
\hline $\begin{array}{l}\text { 2.20 Parental outcomes: } \\
\text { stress (Ability \& }\end{array}$ & 1 & & $\begin{array}{l}\text { Std. Mean Difference (IV, } \\
\text { Fixed, } 95 \% \mathrm{CI})\end{array}$ & No totals \\
\hline
\end{tabular}




\begin{tabular}{|c|c|c|c|c|}
\hline Outcome or Subgroup & Studies & Participants & Statistical Method & Effect Estimate \\
\hline \multicolumn{5}{|l|}{$\begin{array}{l}\text { Confidence Rating } \\
\text { Questionnaire) }\end{array}$} \\
\hline $\begin{array}{l}\text { 2.20.1 Post intervention } \\
\text { (immediate post } \\
\text { intervention up to four } \\
\text { weeks post intervention) }\end{array}$ & 1 & & $\begin{array}{l}\text { Std. Mean Difference (IV, } \\
\text { Fixed, } 95 \% \mathrm{Cl} \text { ) }\end{array}$ & No totals \\
\hline $\begin{array}{l}\text { 2.21 Parental outcomes: } \\
\text { stress (Parental Stress } \\
\text { Scale) }\end{array}$ & 1 & & $\begin{array}{l}\text { Std. Mean Difference (IV, } \\
\text { Fixed, } 95 \% \mathrm{Cl} \text { ) }\end{array}$ & No totals \\
\hline $\begin{array}{l}\text { 2.21.1 Post intervention } \\
\text { (immediate post } \\
\text { intervention up to four } \\
\text { weeks post intervention) }\end{array}$ & 1 & & $\begin{array}{l}\text { Std. Mean Difference (IV, } \\
\text { Fixed, } 95 \% \mathrm{Cl} \text { ) }\end{array}$ & No totals \\
\hline $\begin{array}{l}\text { 2.21.2 Short term follow } \\
\text { up (one to six months post } \\
\text { intervention) }\end{array}$ & 1 & & $\begin{array}{l}\text { Std. Mean Difference (IV, } \\
\text { Fixed, } 95 \% \mathrm{Cl} \text { ) }\end{array}$ & No totals \\
\hline $\begin{array}{l}\text { 2.22 Parental outcomes: } \\
\text { stress (modified Uplifts \& } \\
\text { Hassles Scale: hassles } \\
\text { scale) }\end{array}$ & 2 & & $\begin{array}{l}\text { Std. Mean Difference (IV, } \\
\text { Fixed, } 95 \% \mathrm{Cl} \text { ) }\end{array}$ & No totals \\
\hline $\begin{array}{l}\text { 2.22.1 Post intervention } \\
\text { (immediate post } \\
\text { intervention up to four } \\
\text { weeks post intervention) }\end{array}$ & 1 & & $\begin{array}{l}\text { Std. Mean Difference (IV, } \\
\text { Fixed, } 95 \% \mathrm{Cl} \text { ) }\end{array}$ & No totals \\
\hline $\begin{array}{l}\text { 2.22.2 Short term follow } \\
\text { up (one to six months post } \\
\text { intervention) }\end{array}$ & 1 & & $\begin{array}{l}\text { Std. Mean Difference (IV, } \\
\text { Fixed, } 95 \% \mathrm{Cl} \text { ) }\end{array}$ & No totals \\
\hline $\begin{array}{l}\text { 2.23 Parental outcomes: } \\
\text { stress (subscale of } \\
\text { Depression Anxiety Stress } \\
\text { Scale) }\end{array}$ & 8 & & $\begin{array}{l}\text { Std. Mean Difference (IV, } \\
\text { Fixed, } 95 \% \mathrm{Cl} \text { ) }\end{array}$ & No totals \\
\hline $\begin{array}{l}\text { 2.23.1 Post intervention } \\
\text { (immediate post } \\
\text { intervention up to four } \\
\text { weeks post intervention) }\end{array}$ & 6 & & $\begin{array}{l}\text { Std. Mean Difference (IV, } \\
\text { Fixed, } 95 \% \mathrm{Cl} \text { ) }\end{array}$ & No totals \\
\hline $\begin{array}{l}\text { 2.23.2 Short term follow } \\
\text { up (one to six months post } \\
\text { intervention) }\end{array}$ & 2 & & $\begin{array}{l}\text { Std. Mean Difference (IV, } \\
\text { Fixed, } 95 \% \mathrm{Cl} \text { ) }\end{array}$ & No totals \\
\hline $\begin{array}{l}\text { 2.23.3 Long term follow } \\
\text { up (more than six months } \\
\text { post intervention) }\end{array}$ & 1 & & $\begin{array}{l}\text { Std. Mean Difference (IV, } \\
\text { Fixed, } 95 \% \mathrm{Cl} \text { ) }\end{array}$ & No totals \\
\hline $\begin{array}{l}\text { 2.24 Parental outcomes: } \\
\text { self-esteem (Rosenberg }\end{array}$ & 3 & & $\begin{array}{l}\text { Std. Mean Difference (IV, } \\
\text { Fixed, } 95 \% \mathrm{Cl} \text { ) }\end{array}$ & No totals \\
\hline
\end{tabular}




\begin{tabular}{|c|c|c|c|c|}
\hline Outcome or Subgroup & Studies & Participants & Statistical Method & Effect Estimate \\
\hline \multicolumn{5}{|l|}{ Self-Esteem scale) } \\
\hline $\begin{array}{l}\text { 2.24.1 Post intervention } \\
\text { (immediate post } \\
\text { intervention up to four } \\
\text { weeks post intervention) }\end{array}$ & 2 & & $\begin{array}{l}\text { Std. Mean Difference (IV, } \\
\text { Fixed, } 95 \% \mathrm{Cl} \text { ) }\end{array}$ & No totals \\
\hline $\begin{array}{l}\text { 2.24.2 Short term follow } \\
\text { up (one to six months post } \\
\text { intervention) }\end{array}$ & 2 & & $\begin{array}{l}\text { Std. Mean Difference (IV, } \\
\text { Fixed, } 95 \% \mathrm{Cl} \text { ) }\end{array}$ & No totals \\
\hline $\begin{array}{l}\text { 2.24.3 Long term follow } \\
\text { up (more than six months } \\
\text { post intervention) }\end{array}$ & 2 & & $\begin{array}{l}\text { Std. Mean Difference (IV, } \\
\text { Fixed, } 95 \% \mathrm{Cl} \text { ) }\end{array}$ & No totals \\
\hline $\begin{array}{l}2.25 \text { Parental outcomes: } \\
\text { anger (subscale of } \\
\text { Berger's Feeling Scale) }\end{array}$ & 2 & & $\begin{array}{l}\text { Std. Mean Difference (IV, } \\
\text { Fixed, } 95 \% \mathrm{Cl} \text { ) }\end{array}$ & No totals \\
\hline $\begin{array}{l}\text { 2.25.1 Post intervention } \\
\text { (immediate post } \\
\text { intervention up to four } \\
\text { weeks post intervention) }\end{array}$ & 2 & & $\begin{array}{l}\text { Std. Mean Difference (IV, } \\
\text { Fixed, } 95 \% \mathrm{Cl} \text { ) }\end{array}$ & No totals \\
\hline $\begin{array}{l}\text { 2.26 Parental outcomes: } \\
\text { anger (State-Trait Anger } \\
\text { Expression Inventory } \\
\text { scale) }\end{array}$ & 1 & & $\begin{array}{l}\text { Std. Mean Difference (IV, } \\
\text { Fixed, } 95 \% \mathrm{Cl} \text { ) }\end{array}$ & No totals \\
\hline $\begin{array}{l}\text { 2.26.1 Post intervention } \\
\text { (immediate post } \\
\text { intervention up to four } \\
\text { weeks post intervention) }\end{array}$ & 1 & & $\begin{array}{l}\text { Std. Mean Difference (IV, } \\
\text { Fixed, 95\% Cl) }\end{array}$ & No totals \\
\hline $\begin{array}{l}\text { 2.27 Parental outcomes: } \\
\text { guilt (subscale of Berger's } \\
\text { Feeling Scale) }\end{array}$ & 2 & & $\begin{array}{l}\text { Std. Mean Difference (IV, } \\
\text { Fixed, } 95 \% \mathrm{Cl} \text { ) }\end{array}$ & No totals \\
\hline $\begin{array}{l}\text { 2.27.1 Post intervention } \\
\text { (immediate post } \\
\text { intervention up to four } \\
\text { weeks post intervention) }\end{array}$ & 2 & & $\begin{array}{l}\text { Std. Mean Difference (IV, } \\
\text { Fixed, } 95 \% \mathrm{Cl} \text { ) }\end{array}$ & No totals \\
\hline $\begin{array}{l}\text { 2.28 Parental outcomes: } \\
\text { guilt (Situation Guilt Scale) }\end{array}$ & 1 & & $\begin{array}{l}\text { Std. Mean Difference (IV, } \\
\text { Fixed, 95\% CI) }\end{array}$ & No totals \\
\hline $\begin{array}{l}\text { 2.28.1 Post intervention } \\
\text { (immediate post } \\
\text { intervention up to four } \\
\text { weeks post intervention) }\end{array}$ & 1 & & $\begin{array}{l}\text { Std. Mean Difference (IV, } \\
\text { Fixed, } 95 \% \mathrm{Cl} \text { ) }\end{array}$ & No totals \\
\hline $\begin{array}{l}\text { 2.29 Parental outcomes: } \\
\text { confidence (Parenting } \\
\text { Task Checklist) }\end{array}$ & 2 & & $\begin{array}{l}\text { Std. Mean Difference (IV, } \\
\text { Fixed, } 95 \% \mathrm{Cl} \text { ) }\end{array}$ & No totals \\
\hline 2.29.1 Post intervention & 2 & & Std. Mean Difference (IV, & No totals \\
\hline
\end{tabular}




\begin{tabular}{|c|c|c|c|c|}
\hline Outcome or Subgroup & Studies & Participants & Statistical Method & Effect Estimate \\
\hline $\begin{array}{l}\text { (immediate post } \\
\text { intervention up to four } \\
\text { weeks post intervention) }\end{array}$ & & & Fixed, 95\% Cl) & \\
\hline $\begin{array}{l}\text { 2.30 Parental outcomes: } \\
\text { confidence (Parental } \\
\text { Efficacy measure) }\end{array}$ & 1 & & $\begin{array}{l}\text { Std. Mean Difference (IV, } \\
\text { Fixed, } 95 \% \mathrm{CI} \text { ) }\end{array}$ & No totals \\
\hline $\begin{array}{l}\text { 2.30.1 Short term follow } \\
\text { up (one to six months post } \\
\text { intervention) }\end{array}$ & 1 & & $\begin{array}{l}\text { Std. Mean Difference (IV, } \\
\text { Fixed, } 95 \% \mathrm{Cl} \text { ) }\end{array}$ & No totals \\
\hline $\begin{array}{l}\text { 2.31 Parental outcomes: } \\
\text { confidence (Parenting } \\
\text { Stress Index) }\end{array}$ & 1 & & $\begin{array}{l}\text { Std. Mean Difference (IV, } \\
\text { Fixed, } 95 \% \mathrm{Cl} \text { ) }\end{array}$ & No totals \\
\hline $\begin{array}{l}\text { 2.31.1 Post intervention } \\
\text { (immediate post } \\
\text { intervention up to four } \\
\text { weeks post intervention) }\end{array}$ & 1 & & $\begin{array}{l}\text { Std. Mean Difference (IV, } \\
\text { Fixed, } 95 \% \mathrm{Cl} \text { ) }\end{array}$ & No totals \\
\hline $\begin{array}{l}\text { 2.31.2 Short term follow } \\
\text { up (one to six months post } \\
\text { intervention) }\end{array}$ & 1 & & $\begin{array}{l}\text { Std. Mean Difference (IV, } \\
\text { Fixed, } 95 \% \mathrm{Cl} \text { ) }\end{array}$ & No totals \\
\hline $\begin{array}{l}\text { 2.32 Parental outcomes: } \\
\text { confidence (Toddler Care } \\
\text { Questionnaire) }\end{array}$ & 3 & & $\begin{array}{l}\text { Std. Mean Difference (IV, } \\
\text { Fixed, 95\% CI) }\end{array}$ & No totals \\
\hline $\begin{array}{l}\text { 2.32.1 Post intervention } \\
\text { (immediate post } \\
\text { intervention up to four } \\
\text { weeks post intervention) }\end{array}$ & 3 & & $\begin{array}{l}\text { Std. Mean Difference (IV, } \\
\text { Fixed, } 95 \% \mathrm{Cl} \text { ) }\end{array}$ & No totals \\
\hline $\begin{array}{l}\text { 2.32.2 Short term follow } \\
\text { up (one to six months post } \\
\text { intervention) }\end{array}$ & 3 & & $\begin{array}{l}\text { Std. Mean Difference (IV, } \\
\text { Fixed, } 95 \% \mathrm{Cl} \text { ) }\end{array}$ & No totals \\
\hline $\begin{array}{l}\text { 2.32.3 Long term follow } \\
\text { up (more than six months } \\
\text { post intervention) }\end{array}$ & 2 & & $\begin{array}{l}\text { Std. Mean Difference (IV, } \\
\text { Fixed, } 95 \% \mathrm{Cl} \text { ) }\end{array}$ & No totals \\
\hline $\begin{array}{l}\text { 2.33 Parental outcomes: } \\
\text { confidence (Parenting } \\
\text { Sense of Competence } \\
\text { Scale: total score) }\end{array}$ & 4 & & $\begin{array}{l}\text { Std. Mean Difference (IV, } \\
\text { Fixed, 95\% CI) }\end{array}$ & No totals \\
\hline $\begin{array}{l}\text { 2.33.1 Post intervention } \\
\text { (immediate post } \\
\text { intervention up to four } \\
\text { weeks post intervention) }\end{array}$ & 4 & & $\begin{array}{l}\text { Std. Mean Difference (IV, } \\
\text { Fixed, } 95 \% \mathrm{Cl} \text { ) }\end{array}$ & No totals \\
\hline $\begin{array}{l}\text { 2.33.2 Short term follow } \\
\text { up (one to six months post } \\
\text { intervention) }\end{array}$ & 1 & & $\begin{array}{l}\text { Std. Mean Difference (IV, } \\
\text { Fixed, } 95 \% \mathrm{CI} \text { ) }\end{array}$ & No totals \\
\hline
\end{tabular}




\begin{tabular}{|c|c|c|c|c|}
\hline Outcome or Subgroup & Studies & Participants & Statistical Method & Effect Estimate \\
\hline $\begin{array}{l}\text { 2.34 Parental outcomes: } \\
\text { confidence (Problem } \\
\text { Setting \& Behaviour } \\
\text { Checklist) }\end{array}$ & 3 & & $\begin{array}{l}\text { Std. Mean Difference (IV, } \\
\text { Fixed, 95\% CI) }\end{array}$ & No totals \\
\hline $\begin{array}{l}\text { 2.34.1 Post intervention } \\
\text { (immediate post } \\
\text { intervention up to four } \\
\text { weeks post intervention) }\end{array}$ & 3 & & $\begin{array}{l}\text { Std. Mean Difference (IV, } \\
\text { Fixed, } 95 \% \mathrm{CI} \text { ) }\end{array}$ & No totals \\
\hline $\begin{array}{l}\text { 2.35 Parental outcomes: } \\
\text { confidence (Kansas } \\
\text { Parental Satisfaction } \\
\text { Scale: satisfaction in } \\
\text { parental role) }\end{array}$ & 1 & & $\begin{array}{l}\text { Std. Mean Difference (IV, } \\
\text { Fixed, } 95 \% \mathrm{Cl} \text { ) }\end{array}$ & No totals \\
\hline $\begin{array}{l}\text { 2.35.1 Post intervention } \\
\text { (immediate post } \\
\text { intervention up to four } \\
\text { weeks post intervention) }\end{array}$ & 1 & & $\begin{array}{l}\text { Std. Mean Difference (IV, } \\
\text { Fixed, } 95 \% \mathrm{CI} \text { ) }\end{array}$ & No totals \\
\hline $\begin{array}{l}\text { 2.35.2 Short term follow } \\
\text { up (one to six months post } \\
\text { intervention) }\end{array}$ & 1 & & $\begin{array}{l}\text { Std. Mean Difference (IV, } \\
\text { Fixed, } 95 \% \mathrm{Cl} \text { ) }\end{array}$ & No totals \\
\hline $\begin{array}{l}\text { 2.36 Parental outcomes: } \\
\text { partner satisfaction } \\
\text { (Dyadic Adjustment Scale) }\end{array}$ & 2 & & $\begin{array}{l}\text { Std. Mean Difference (IV, } \\
\text { Fixed, } 95 \% \mathrm{Cl} \text { ) }\end{array}$ & No totals \\
\hline $\begin{array}{l}\text { 2.36.1 Post intervention } \\
\text { (immediate post } \\
\text { intervention up to four } \\
\text { weeks post intervention) }\end{array}$ & 2 & & $\begin{array}{l}\text { Std. Mean Difference (IV, } \\
\text { Fixed, } 95 \% \mathrm{CI} \text { ) }\end{array}$ & No totals \\
\hline $\begin{array}{l}\text { 2.37 Parental outcomes: } \\
\text { partner satisfaction } \\
\text { (Locke-Wallace Marital } \\
\text { Adjustment Test) }\end{array}$ & 2 & & $\begin{array}{l}\text { Std. Mean Difference (IV, } \\
\text { Fixed, 95\% CI) }\end{array}$ & No totals \\
\hline $\begin{array}{l}\text { 2.37.1 Post intervention } \\
\text { (immediate post } \\
\text { intervention up to four } \\
\text { weeks post intervention) }\end{array}$ & 2 & & $\begin{array}{l}\text { Std. Mean Difference (IV, } \\
\text { Fixed, 95\% Cl) }\end{array}$ & No totals \\
\hline $\begin{array}{l}\text { 2.38 Parental outcomes: } \\
\text { partner satisfaction } \\
\text { (Parenting Stress Index) }\end{array}$ & 2 & & $\begin{array}{l}\text { Std. Mean Difference (IV, } \\
\text { Fixed, 95\% CI) }\end{array}$ & No totals \\
\hline $\begin{array}{l}\text { 2.38.1 Post intervention } \\
\text { (immediate post } \\
\text { intervention up to four } \\
\text { weeks post intervention) }\end{array}$ & 2 & & $\begin{array}{l}\text { Std. Mean Difference (IV, } \\
\text { Fixed, } 95 \% \mathrm{Cl} \text { ) }\end{array}$ & No totals \\
\hline 2.38.2 Short term follow & 1 & & Std. Mean Difference (IV, & No totals \\
\hline
\end{tabular}




\begin{tabular}{|c|c|c|c|c|}
\hline Outcome or Subgroup & Studies & Participants & Statistical Method & Effect Estimate \\
\hline $\begin{array}{l}\text { up (one to six months post } \\
\text { intervention) }\end{array}$ & & & Fixed, 95\% Cl) & \\
\hline $\begin{array}{l}\text { 2.39 Parental outcomes: } \\
\text { partner satisfaction } \\
\text { (Relation Quality Index) }\end{array}$ & 3 & & $\begin{array}{l}\text { Std. Mean Difference (IV, } \\
\text { Fixed, } 95 \% \mathrm{Cl} \text { ) }\end{array}$ & No totals \\
\hline $\begin{array}{l}\text { 2.39.1 Post intervention } \\
\text { (immediate post } \\
\text { intervention up to four } \\
\text { weeks post intervention) }\end{array}$ & 3 & & $\begin{array}{l}\text { Std. Mean Difference (IV, } \\
\text { Fixed, } 95 \% \mathrm{Cl} \text { ) }\end{array}$ & No totals \\
\hline $\begin{array}{l}\text { 2.40 Father outcomes: } \\
\text { depressive symptoms } \\
\text { (Beck Depression } \\
\text { Inventory) }\end{array}$ & 1 & & $\begin{array}{l}\text { Std. Mean Difference (IV, } \\
\text { Random, 95\% Cl) }\end{array}$ & Subtotals only \\
\hline $\begin{array}{l}\text { 2.40.1 Post intervention } \\
\text { (immediate post } \\
\text { intervention up to four } \\
\text { weeks post intervention) }\end{array}$ & 1 & 18 & $\begin{array}{l}\text { Std. Mean Difference (IV, } \\
\text { Random, 95\% Cl) }\end{array}$ & $-0.53[-1.48,0.42]$ \\
\hline $\begin{array}{l}\text { 2.41 Father outcomes: } \\
\text { depressive symptoms } \\
\text { (Center for } \\
\text { Epidemiological Studies } \\
\text { Depression Scale }\end{array}$ & 1 & & $\begin{array}{l}\text { Std. Mean Difference (IV, } \\
\text { Random, 95\% Cl) }\end{array}$ & Subtotals only \\
\hline $\begin{array}{l}\text { 2.41.1 Post intervention } \\
\text { (immediate post } \\
\text { intervention up to four } \\
\text { weeks post intervention) }\end{array}$ & 1 & 16 & $\begin{array}{l}\text { Std. Mean Difference (IV, } \\
\text { Random, 95\% Cl) }\end{array}$ & $-0.39[-1.41,0.64]$ \\
\hline $\begin{array}{l}\text { 2.41.2 Short term follow } \\
\text { up (one to six months post } \\
\text { intervention) }\end{array}$ & 1 & 16 & $\begin{array}{l}\text { Std. Mean Difference (IV, } \\
\text { Random, 95\% CI) }\end{array}$ & $-0.63[-1.67,0.42]$ \\
\hline $\begin{array}{l}\text { 2.42 Father outcomes: } \\
\text { stress (Parenting Stress } \\
\text { Index: parent domain } \\
\text { subscale) }\end{array}$ & 4 & & $\begin{array}{l}\text { Std. Mean Difference (IV, } \\
\text { Random, 95\% Cl) }\end{array}$ & Subtotals only \\
\hline $\begin{array}{l}\text { 2.42.1 Post intervention } \\
\text { (immediate post } \\
\text { intervention up to four } \\
\text { weeks post intervention) }\end{array}$ & 4 & 123 & $\begin{array}{l}\text { Std. Mean Difference (IV, } \\
\text { Random, 95\% Cl) }\end{array}$ & $-0.43[-0.79,-0.06]$ \\
\hline $\begin{array}{l}\text { 2.42.2 Short term follow } \\
\text { up (one to six months post } \\
\text { intervention) }\end{array}$ & 1 & 16 & $\begin{array}{l}\text { Std. Mean Difference (IV, } \\
\text { Random, 95\% Cl) }\end{array}$ & $-0.24[-1.25,0.78]$ \\
\hline $\begin{array}{l}\text { 2.43 Father outcomes: } \\
\text { confidence (Toddler Care } \\
\text { Questionnaire: overall }\end{array}$ & 1 & & $\begin{array}{l}\text { Std. Mean Difference (IV, } \\
\text { Random, 95\% Cl) }\end{array}$ & Subtotals only \\
\hline
\end{tabular}




\begin{tabular}{|c|c|c|c|c|}
\hline Outcome or Subgroup & Studies & Participants & Statistical Method & Effect Estimate \\
\hline \multicolumn{5}{|l|}{ scores) } \\
\hline $\begin{array}{l}\text { 2.43.1 Post intervention } \\
\text { (immediate post } \\
\text { intervention up to four } \\
\text { weeks post intervention) }\end{array}$ & 1 & 17 & $\begin{array}{l}\text { Std. Mean Difference (IV, } \\
\text { Random, } 95 \% \mathrm{CI} \text { ) }\end{array}$ & $-0.07[-1.06,0.93]$ \\
\hline $\begin{array}{l}\text { 2.43.2 Short term follow } \\
\text { up (one to six months post } \\
\text { intervention) }\end{array}$ & 1 & 17 & $\begin{array}{l}\text { Std. Mean Difference (IV, } \\
\text { Random, } 95 \% \mathrm{CI} \text { ) }\end{array}$ & $0.68[-0.35,1.70]$ \\
\hline $\begin{array}{l}\text { 2.44 Father outcomes: } \\
\text { partner satisfaction } \\
\text { (Locke-Wallace Marital } \\
\text { Adjustment Test) }\end{array}$ & 1 & & $\begin{array}{l}\text { Std. Mean Difference (IV, } \\
\text { Random, } 95 \% \mathrm{CI} \text { ) }\end{array}$ & Subtotals only \\
\hline $\begin{array}{l}\text { 2.44.1 Post intervention } \\
\text { (immediate post } \\
\text { intervention up to four } \\
\text { weeks post intervention) }\end{array}$ & 1 & 16 & $\begin{array}{l}\text { Std. Mean Difference (IV, } \\
\text { Random, 95\% CI) }\end{array}$ & $0.63[-0.39,1.65]$ \\
\hline
\end{tabular}




\section{Figures}

\subsection{RISK OF BIAS SUMMARY: REVIEW AUTHORS' J UDGEMENTS ABOUT EACH RISK OF EACH INCLUDED STUDY}

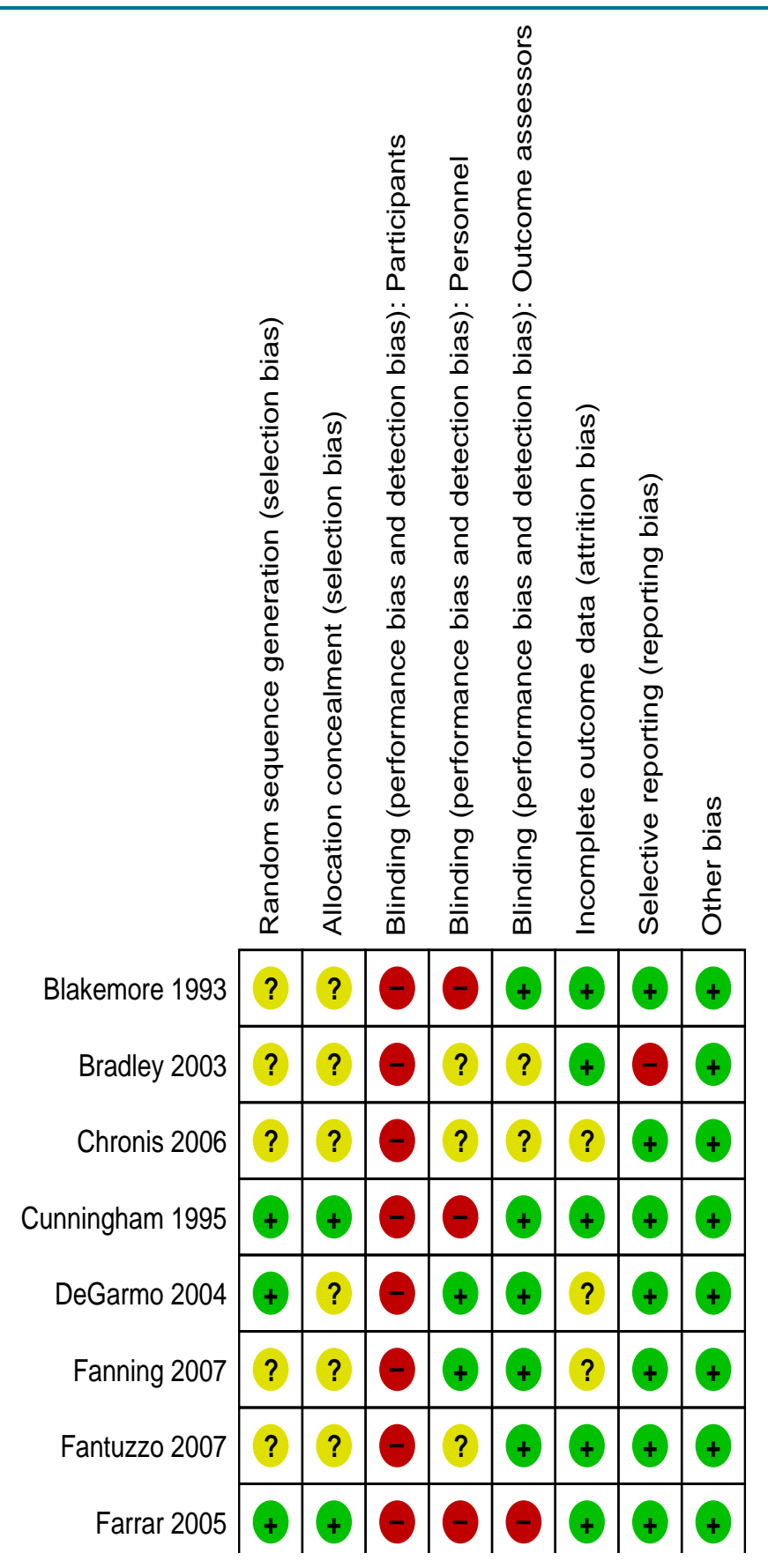



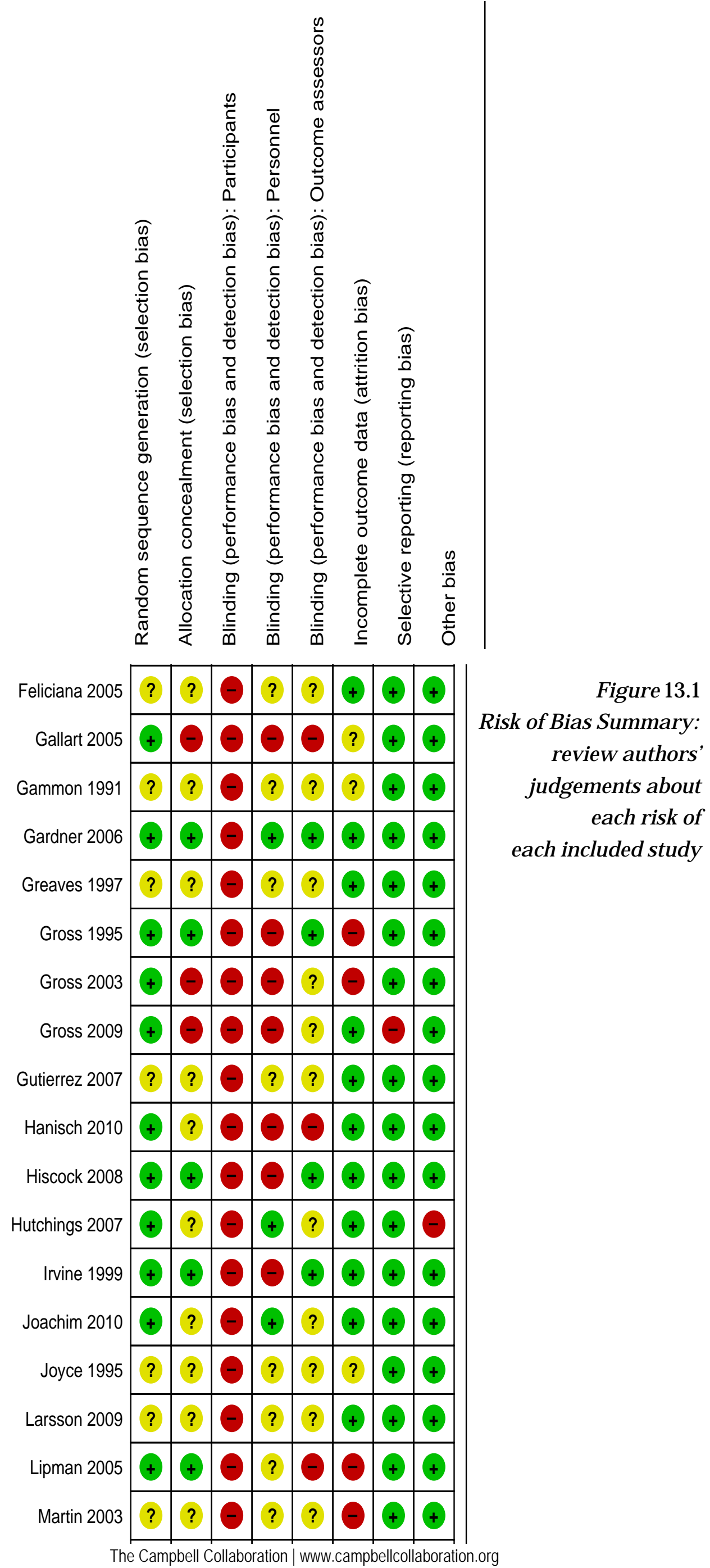


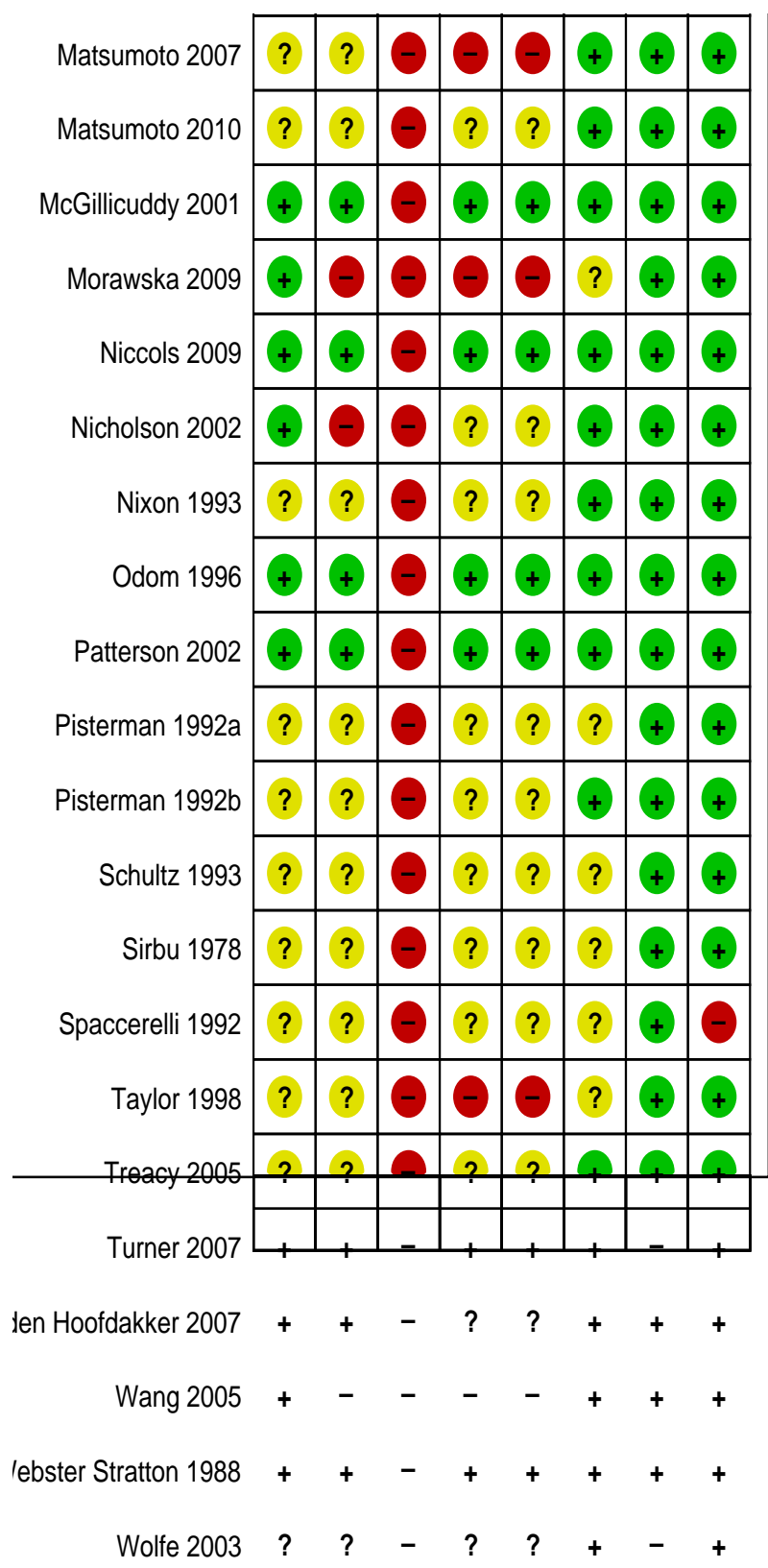

Figure 13.1

Risk of Bias Summary: review authors' judgements about each risk of each included study 


\section{Appendices}

\subsection{SEARCH STRATEGY}

\section{MEDLINE}

1 (parent\$-program\$ or parent\$-training or parent\$-education or parent\$promotion).tw.

2 (parent\$ program\$ or parent\$ training or parent\$ education or parent\$ promotion).tw.

31 or 2

\section{ASSIA (Applied Social Sciences Index and Abstracts database)}

(((parent*-program* or parent*-training or parent*-education or parent*promotion)) or ((parent* program* or parent* training or parent* education or parent* promotion)))

\section{BIOSIS}

(ts $=\left(\right.$ parent*-program* ${ }^{*}$ or parent*-training or parent*-education or parent*promotion) $)$ or ( ts $=$ (parent* program* or parent* training or parent* education or parent* promotion))

\section{CENTRAL}

\#1 parent*-program* or parent*-training or parent*-education or parent*promotion

\#2 parent next program* or parent* next training or parent* next education or parent* next promotion

\#3 (\#1 OR \#2)

\section{CINAHL}

( parent*-program* or parent*-training or parent*-education or parent*-promotion ) or ( parent* program* or parent* training or parent* education or parent* promotion )

\subsubsection{EMBASE}

1 (parent\$-program\$ or parent\$-training or parent\$-education or parent\$promotion).tw. 
2 (parent\$ program\$ or parent\$ training or parent\$ education or parent\$ promotion).tw.

31 or 2

\section{PsycINFO}

(parent* promotion OR parent* training OR parent* education OR parent* program* OR parent*-promotion OR parent*-training OR parent*-education OR parent*-program*)

\section{Sociological Abstracts via CSA (March 2010 and February 2008)}

(TI $=($ (parent* program*) or (parent*training) or (parent* education) or (parent* promotion) $)$ or $\mathrm{AB}=($ (parent* program*) or (parent* training) or (parent* education) or (parent* promotion) $)$ or $\mathrm{DE}=($ (parent* program*) or (parent*training) or (parent*education) or (parent*promotion))) or (TI=(parent*-program* or parent*-training or parent*-education or parent*-promotion) or $\mathrm{AB}=$ (parent*-program* or parent*-training or parent*-education or parent*-promotion) or $\mathrm{DE}=($ parent*-program* or parent*-training or parent*-education or parent*-promotion))

\section{Sociological Abstracts via Proquest ( December 2011)}

all(parent*-program* OR parent*-training OR parent*-education OR parent*promotion) Limits applied Databases: Sociological Abstracts

Limited by: Date: After 2010 Document type:J ournal Article

\section{Social Science Citation Index}

Social Science Citation Index searched using ISI Web of Knowledge.

(ts $=$ (parent*-program* or parent*-training or parent*-education or parent*promotion) $)$ or( ts=(parent* program* or parent* training or parent* education or parent* promotion))

\section{ERIC via Ovid (March 2010 and February 2008)}

1 randomi?ed.tw.

2 ((singl\$ or doubl\$ or treb\$ or tripl\$) adj3 (blind\$ or mask\$)).tw.

3 placebo.tw.

4 (clin\$ adj3 trial\$).tw.

5 exp methods research/

6 (random\$ adj5 (allocat\$ or assign\$ or select\$)).tw.

7 ((control\$ or prospectiv\$) adj5 (trial\$ or study or studies)).tw.

81 or 2 or 3 or 4 or 5 or 6 or 7

9 (parent\$ adj3 (program\$ or educat\$ or train\$ promot\$)).tw.

10 "parent-program\$".tw.

11 "parent-train $\$$ ".tw

12 "parent-educat\$".tw. 
13 "parent-promot\$".tw.

149 or 10 or 11 or 12 or 13

158 and 14

\section{ERIC via www.eric.ed.gov (December 2011)}

((Keywords: "parent train*" or Keywords:"parent promot*" or Keywords:"parent educat*" or Keywords: "parent program*") or (Keywords: "parent-program*" or Keywords:"parent-train*" or Keywords:"parent-educat*" or Keywords:"parentpromot*")

\section{National Research Register}

\#1(parent*-program* or parent*-training or parent*-education or parent*promotion) in ti, ab, de

\#2(parent* program* or parent* training or parent* education or parent* promotion) in ti, ab, de

\#3 \#1 or \#2

\section{NSPCC Library Catalogue}

parent program OR parent training OR parent education OR parent promotion (Title or Subject Term. Truncation box ticked)

\section{mRCT}

Searched using the following key words:

parent program

parent programme

parent training

parent education

parent promotion 